\title{
Aplicação de laminado de polímero reforçado com fibras de carbono (PRFC) inserido em substrato de microconcreto com fibras de aço para reforço à flexão de vigas de concreto armado
}

\author{
Ana Paula Arquez
}

Dissertação apresentada à Escola de Engenharia de São Carlos da Universidade de São Paulo, como parte dos requisitos para a obtenção do título de Mestre em Engenharia de Estruturas.

Orientador: Prof. Titular João Bento de Hanai

São Carlos 
AUTORIZO A REPRODUÇÄO E DIVULGAÇÄO TOTAL OU PARCIAL DESTE TRABALHO, POR QUALQUER MEIO CONVENCIONAL OU ELETRÔNICO, PARA FINS DE ESTUDO E PESQUISA, DESDE QUE CITADA A FONTE.

Ficha catalográfica preparada pela Seção de Tratamento da Informação do Serviço de Biblioteca - EESC/USP

A $772 a$

Arquez, Ana Paula

Aplicação de laninado de polímero reforçado com fibras de carbono (PRFC) inserido em substrato de microconcreto com fibras de aço para reforço à flexão de vigas de concreto armado / Ana Paula Arquez; orientador João Bento de Hanai. -- São Carlos, 2010.

Dissertação (Mestrado-Programa de Pós-Graduação e Área de Concentração en Engenharia de Estruturas) -- Escola de Engenharia de São Carlos da Universidade de São Paulo, 2010 .

1. Estruturas - reabilitação. 2. Reforço de vigas. 3. Fibras de carbono (PREC). 4. Concreto com fibras de aço. 5. Compósito cimentício. 6. Aderência. I. Título. 
FOLHA DE JULGAMENTO

Candidato(a): Engenheiro ANA PAULA ARQUEZ.

Dissertação defendida e julgada em 07/05/2010 perante a Comissão Julgadora:

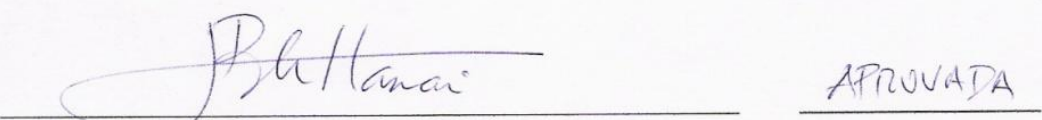

Prof. Titular JOÃO BENTO DE HANAI - (Orientador)

(Escola de Engenharia de São Carlos/USP)

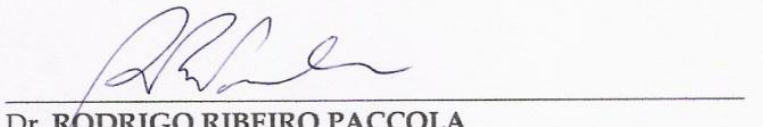

Aprovasa

Dr. RODRIGO RIBEIRO PACCOLA

(Escola de Engenharia de São Carlos/USP)

$$
\text { Giy fulau } h
$$

Prof. Dr. SYDNEY FURLAN JUNIOR

(Universidade Federal de São Carlos/UFSCar)

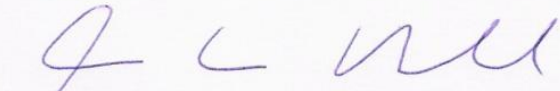

Prof. Associado MARCIO ANTONIO RAMALHO

Coordenador do Programa de Pós-Graduação em

Engenharia Civil (Engenharia de Estruturas)

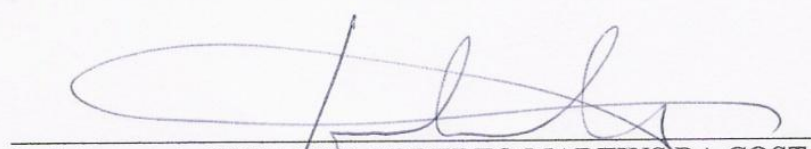

Prof. Associado GERAL DO ROBERTO MARTINS DA COSTA

Presidente da Comissão de Pós-Graduação 

Aos meus pais, Angela e Francisco, à minha irmã Isabel, ao meu maninho Márcio e ao meu namorado Daniel, com muito amor e gratidão. 

"Sou brasileiro e não desisto nunca" Edson Corrêa 

Em primeiro lugar, agradeço a Deus pela oportunidade dada e pela confiança de que estava fazendo a coisa certa mesmo deixando longe, tantas pessoas queridas. Agradeço também, por ter me dado coragem para sair do mercado de trabalho e adentrar num mundo, que até então não me pertencia. Agradeço, sobretudo, por ter colocado pessoas maravilhosas ao meu redor, que com certeza, facilitaram o tortuoso caminho até chegar à conclusão de mais uma etapa da minha vida.

Aos meus pais, agradeço todo o incentivo, a paciência, a confiança e o amor que nunca faltou em toda minha vida. Sempre prontos a me ajudar e com palavras confortantes quando eu achava que não conseguiria chegar ao final. Sem contar todas as vezes que suportaram meu "xororo" quando tinha que sair de Maringá. E isso durou o período todo do mestrado...

À minha querida irmã Isabel e o meu querido cunhado-irmão, que apesar da distância, estiveram sempre presentes na alegria e na tristeza, com direito a diversos incentivos e puxões de orelha. Vocês podem!

Aos amigos maringaenses do Futura: Denise, Ronaldo, Márcia, Gustavo, Paulinho e Jorginho. Nosso único problema é nos vermos pouco. Obrigada pessoal!

Sair de casa, embora seja um crescimento pessoal, não é uma missão confortável (no sentido literal da palavra), principalmente para morar com pessoas nunca vistas antes. Mas tive muita sorte! Mesmo passando por momentos delicados, encontrei uma segunda família escondida atrás de várias personalidades. São membros dessa família: Rê, Flor (Cynthia), Mário (Rodrigo), Gigi (Giovanne) e Mineiro (Wanderson). Muito obrigada pela atenção e principalmente pela paciência que tiveram comigo.

Mário, obrigada por me salvar várias vezes. Desde a época dos estudos para provas até a impressão desse trabalho. Sem palavras para agradecê-lo. Flor, ainda temos muitas metas para cumprir. Rê foi bom demais morar com você. Desde os momentos engraçados até àqueles mais melancólicos, passando por muita bagunça.

Também fazem parte dessa lista de pessoas especiais: Dani e Zaca (casal maluco!), Baiano (Leandro), Vinicius, Robenson, Aref, Socorro, Érica, Dorival, Jesus, Marcela, Trakinas (Bruno) e Hugo. 
Agradeço também, duas pessoas extremamente generosas, que mesmo não tendo muita proximidade, me ajudaram sem medir esforços: Tatiana Fonseca e Vladimir Ferrari.

E no meio desse caminho, eis que surge uma pessoa, que também é responsável pela conclusão dessa etapa: Daniel Litvin de Almeida. Dani, muito obrigada pela paciência, pelo apoio incondicional e por muitas vezes abrir mão dos seus planos, para tornar o meu, realidade. Não bastando, ganhei mais uma maravilhosa família. Família Litvin de Almeida, obrigada pela hospedagem, apoio e compreensão. Jú, obrigada pelas verificações e pelo incentivo.

Pelo lado profissional, agradeço a compreensão e apoio do escritório Ruy Bentes Engenharia de Estruturas, sobretudo aos engenheiros Ruy Bentes e Diego Tellaroli, e aos meus queridos e eternos estagiários Bruno, Pedro e Wellington.

Agradeço ao Professor Samuel Giongo por horas e horas de conversa, servindo como meu mentor e incentivador.

Agradeço ao Professor João Bento de Hanai, por ter acredito no meu trabalho e por ter me dado liberdade para expressar minhas idéias.

Aos funcionários e professores do Departamento de Engenharia de Estruturas da EESC-USP, a FAPESP pelo custeio dos ensaios e a CAPES pela bolsa de mestrado concedida, meus sinceros agradecimentos 
ARQUEZ, A.P. (2010). Aplicação de laminado de polímero reforçado com fibras de carbono (PRFC) inserido em substrato de microconcreto com fibras de aço para reforço à flexão de vigas de concreto armado. São Carlos, 2010. Dissertação (Mestrado) - Escola de Engenharia de São Carlos, Universidade de São Paulo.

O reforço de elementos estruturais de concreto armado com uso de polímeros reforçados com fibras de carbono (PRFC) está cada vez mais conhecido, seguro e acessível. Em todo o mundo, a aplicação do PRFC vem sendo estudada sob diversas técnicas. Características como elevada resistência à tração e à corrosão, baixo peso, facilidade e rapidez de aplicação são os principais fatores para essa disseminação. Em particular, a técnica aqui estudada é conhecida como Near Surface Mounted (NSM), que consiste na inserção de laminados de PRFC em entalhes realizados no concreto de cobrimento de elementos de concreto armado. Com dupla área de aderência, ela vem a suprir uma deficiência comum no reforço colado externamente, que é o seu destacamento prematuro. Como nas demais técnicas de reforço à flexão, o material é colado na região do concreto tracionado. Sabe-se que, na prática da intervenção, essa região frequentemente encontra-se danificada por razões diversas, como fissuração causada por ações externas, corrosão da armadura e deterioração do concreto, o que exige a sua prévia reparação. Considerando que a boa qualidade desse reparo é imprescindível à eficiência do reforço, propõe-se uma inovação técnica pela reconstituição da face tracionada da viga com um compósito cimentício de alto desempenho, que sirva como substrato para aplicação do PRFC e elemento de transferência de esforços à estrutura a ser reforçada. Produzido à base de cimento Portland, fibras e microfibras de aço, o compósito tem também potencial para retardar a abertura de fissuras e aumentar a rigidez da viga, melhorando o aproveitamento do reforço. Com apoio da Mecânica do Fraturamento, foi possível encontrar as taxas de fibras e microfibras de aço a serem adicionadas a uma matriz cimentícia especialmente desenvolvida. Foram realizados ensaios de aderência para estudar o processo de transferência de tensões cisalhantes do laminado para o compósito na zona de ancoragem da viga. Uma vez conhecido o comportamento do sistema, foram ensaiadas vigas de concreto armado de tamanho representativo de estruturas reais, em três diferentes versões de ancoragem do laminado, sendo duas delas com uso do compósito cimentício. Comprovou-se a eficiência da inovação proposta, constatando-se o aumento da rigidez e da capacidade de carga da viga reforçada, com excelente aproveitamento do laminado. Além disso, as fibras e microfibras diminuíram a abertura das fissuras em estágios mais avançados de carregamento, sem que se observasse fissuras horizontais próxima ao reforço, que poderiam indicar destacamento iminente do laminado de PRFC.

Palavras-chave: reabilitação - estruturas; reforço de vigas; fibras de carbono (PRFC); concreto com fibras de aço; compósito cimentício; aderência. 

ARQUEZ, A.P. (2010). Application of carbon fiber reinforced polymer (CFRP) strips inserted in a steel fiber reinforced concrete layer (NSM - Near Surface Mounted) for flexural strengthening of reinforced concrete beams. São Carlos, 2010. MSc. Thesis - Escola de Engenharia de São Carlos, Universidade de São Paulo.

Strengthening of reinforced concrete elements with carbon fiber reinforced polymer (CFRP) is increasingly well known, safe and accessible. The application of CFRP has been studied worldwide using various techniques. Features like high tensile strength, corrosion resistance, lightweightness and easy and speedy application are the main factors for dissemination. In particular, the technique here analyzed is known as Near Surface Mounted (NSM), which involves inserting CFRP strips into grooves made on the concrete cover of reinforced concrete elements. With double bonding area, this technique avoids the premature peeling-off that usually takes place in externally bonded CFRP reinforcement. As in others flexural strengthening techniques, the material is bonded in the concrete tension region. It is known in strengthening practice that this region usually requires prior repair. Often it shows up damaged by several reasons such as cracking caused by external actions, reinforcement corrosion and deterioration of the concrete. Whereas the good quality of this repair is essential to strengthening efficiency, an innovative technique is proposed. A high-performance cementitious composite is used as a transition layer for insertion of CFRP strips. The composite is made of Portland cement, steel fibers and microfibers of steel. It also has the potential to delay crack opening and to increase the beam stiffness. Based on Fracture Mechanics, it was possible to find suitable volume fractions of steel fibers and microfibers to be added to the cementitious matrix. Bonding tests were performed to analyze the shear stress transferring from the CFRP laminate to the beam anchorage zone. Once known the system behavior, real size reinforced concrete beams were tested in three different versions of the anchorage conditions, two of them with use of cementitious composites. The efficiency of the proposed innovation was proved by confirming increased stiffness and load capacity of the strengthened beam. In addition, fibers and microfibers allowed the decrease of the crack opening in later loading steps. No horizontal cracks near to the reinforcement were noticed, which means that CFRP laminate peeling-off was not likely to occur.

Keywords: structural rehabilitation; strengthening; RC beams; carbon fibers (CFRP); steel fiber reinforced concrete; cementitious composite; bond. 



\section{LISTA DE FIGURAS}

Figura 1.1 - Desmoronamento da ponte sobre o rio Capivari em janeiro de 2005 31

Figura 1.2 - Situação das pontes da cidade de São Paulo (Adaptado de SINAENCO, 2005) ___ 32

Figura 1.3 - Vista do viaduto O.A.E. que liga Analândia à Itirapina___ 33

Figura 1.4 - Situação do viaduto antes (acima) e após (abaixo) recuperação e reforço ___ 34

Figura 1.5 - Reforço do viaduto de Santa Teresa em Belo Horizonte - MG. __ 35

Figura 1.6 - Detalhe de ruína de viga reforçada com aderência externa de manta___ 36

Figura 1.7 - Sistema de reforço à flexão e ao cisalhamento através da técnica NSM __ 37

Figura 1.8 - Configuração do ensaio realizado por Ferrari (2007) com reconstituição da face tracionada da viga

(Adaptado de FERRARI, 2007, p.214) ___ 39

Figura 2.1 - Linhas de fluxos de tensões em uma placa submetida a carregamento uniforme __ 45

Figura 2.2 - Área de danificação à frente da ponta da fissura em materiais distintos___ 46

Figura 2.3 - Características do modelo da fissura fictícia RILEM TC 162-TDF (2002, p. 264)___ 48

Figura 2.4 - Representação do comportamento "softening" do concreto ___ 49

Figura 2.5 - Processo de transmissão de tensão entre as faces da fissura ___ 52

Figura 2.6 - Diagrama de tensão por deformação elástica de matriz e fibras de alto e baixo módulo de elasticidade trabalhando em conjunto (FIGUEIREDO, 2000, p. 5) ___ 53

Figura 2.7 - Compatibilidade entre fibras e agregados graúdos (Adaptado de FIGUEIREDO, 2000, p. 19)__ 56

Figura 2.8 - Comportamento de matrizes cimentícias (FERRARI, 2007, p.21) __ 56

Figura 2.9- Visão macroscópica de um concreto polido ___ 62

Figura 2.10- Visão microscópica do concreto (Adaptado de GRIGOLI; HELENE, 2001, p.11) ___ 62

Figura 2.11- Micrografia eletrônica de varredura de cristais de hidróxido de cálcio na zona de transição

(MEHTA; MONTEIRO, 1994, p.38)___ 64

Figura 2.12 - Ação física ou efeito filler (TECNOSIL, 2008) ___ 67

Figura 2.13 - Ação química ou pozolânica (TECNOSIL, 2008)___ 68

Figura 2.14 - Aspecto geral de um sistema de PRFC pré-fabricado (Adaptado de JUVANDES, 1999, p.2.22) _ 69

Figura 2.15 - Modelo da seção transversal da fibra de carbono ___ 70

Figura 2.16 - Sistema de reforço à flexão e ao cisalhamento através da técnica NSM __ 75

Figura 2.17 - Esquema de ensaio e detalhamento das vigas da série S1 __ 79

Figura 2.18 - Esquema de ensaio e detalhamento das vigas da série S2 __ 81

Figura 2.19 - Configuração das lajes reforçadas ___ 83

Figura 2.20 - Representação do esquema de ensaio, dimensão e armadura das vigas ___ 85

Figura 2.21 - Posicionamento do entalhe estudado por Blaschko (2003) ___ _ _ _ _ 86

Figura 2.22 - Esquema do ensaio de aderência (Adaptado de CRUZ; BARROS, 2002, p. 10) ___ 87

Figura 2.23 - Forças de arrancamento encontradas nos ensaios ___ 88 
Figura 2.24 - Condição de equilíbrio do modelo analítico proposto 89

Figura 2.25 - Comparação entre resultados obtidos pelos métodos analítico e experimental ___ 90

Figura 2.26 - Modelo analítico proposto, contemplando dupla área de aderência ___ 90

Figura 2.27 - Gráfico para determinação do comprimento de ancoragem ___ 92

Figura 2.28 - Distribuição das tensões de tração em barras e laminados de PRFC __ 93

Figura 2.29 - Formação de fissuras cisalhantes na região do reforço ___ 93

Figura 2.30 - Configuração do ensaio (Adaptado de FONSECA, 2007, p. 87) ___ 95

Figura 2.31 - Variação da tensão de aderência com o comprimento de ancoragem: (a) resina que apresentou problema; (b) resina Sikadur 330 ${ }^{\circledR}$. (Adaptado de FONSECA, 2007, p. 105) ___ 96

Figura 2.32 - Tensões e deformações no estado limite último (Adaptado de ACl 440.1R, 2003, p.18) ___ 100

Figura 3.1 - Laje com quadro patológico avançado ___ 105

Figura 3.2 - Nomenclatura dos compósitos cimentícios de alto desempenho ___ 106

Figura 3.3 - Configuração do ensaio realizado por Ferrari (2007) com reconstituição da face tracionada da viga

(Adaptado de FERRARI, 2007, p.214) ___ 109

Figura 3.4 - Processo de fabricação dos corpos de prova ___ 114

Figura 3.5 - Configuração do ensaio___ 118

Figura 3.6 - Exemplo do gráfico obtido no ensaio de fraturamento (Adaptado de BARROS, 2003, p.2.7) __ 119

Figura 3.7 - Processo de preparação das vigas e corpos de prova __ 124

Figura 3.8 - Situação esquemática do ensaio___ 126

Figura 3.9 - Vigas em processo avançado de fissuração ___ 127

Figura 3.10 - Aspecto da distribuição aleatória das fibras___ 127

Figura 3.11 - Curvas força $x$ deslocamento vertical dos compósitos___ 131

Figura 3.12 - Curvas força $x$ abertura da fissura dos compósitos ___ 133

Figura 3.13 - Comparação entre as forças $F_{L}$ e $F_{M} \_134$

Figura 3.14 - Comparação entre as tensões $f_{f c t, L}$ e $f_{\text {eq,2 }}$

Figura 3.15 - Análise dos valores de tensão de flexão equivalente $f_{q e, 3} \_136$

Figura 3.16 - Comparação entre as tensões residuais ___ 137

Figura 4.1 - Esquema do ensaio de aderência proposto por Cruz e Barros (2003) ___ 140

Figura 4.2 - Processo desde a mistura do concreto até a moldagem dos blocos __ 142

Figura 4.3 - Detalhes do ensaio de caracterização do laminado ___ 144

Figura 4.4 - Aspecto dos laminados após ensaio de caracterização ___ 145

Figura 4.5 - Gráfico tensão x deformação dos três corpos de prova ___ 146

Figura 4.6 - Procedimentos para execução e limpeza dos entalhes ___ 148

Figura 4.7 - Detalhe do conjunto para medição do deslocamento no final da zona de ancoragem ___ 149

Figura 4.8 - Preparação do reforço com seus respectivos comprimentos de ancoragem __ 150

Figura 4.9 - Esquema de montagem do ensaio ___ 151

Figura 4.10 - Diagrama tensão x deformação dos sistemas de compósitos de fibras de carbono (CFC) ___ 152 
Figura 4.11 - Gráficos força no laminado x tempo de todos os modelos obtidos pela equação de equilíbrio e pelo extensômetro

Figura 4.12 - Gráfico força máxima no laminado x comprimento de ancoragem dos modelos com valores obtidos pela equação de equilíbrio

Figura 4.13 - Gráfico força no laminado x deslocamento vertical dos modelos com valores obtidos pela equação de equilíbrio 156

Figura 4.14 - Gráficos tensão de cisalhamento x deslizamento 158

Figura 4.15 - Gráfico força no laminado x deslizamento 159

Figura 4.16 - Gráfico tensão no laminado x comprimento de ancoragem 160

Figura 5.1 - Detalhamento das armaduras das vigas 162

Figura 5.2 - Concretagem das vigas 163

Figura 5.3 - Detalhes dos grupos das vigas 164

Figura 5.4 - Marcação e apicoamento das vigas 165

Figura 5.5 - Processo de reabilitação das vigas 166

Figura 5.6 - Posicionamento dos laminados na seção transversal da viga 167

Figura 5.7 - Execução do entalhe por meio de via úmida 167

Figura 5.8 - Mistura da resina 168

Figura 5.9 - Processo de reforço 170

Figura 5.10 - Esquema estático do ensaio das vigas principais 170

Figura 5.11 - Esquema geral do ensaio à flexão 171

Figura 5.12 - Esquema geral do ensaio à flexão 171

Figura 5.13 - Posicionamento dos equipamentos na viga

Figura 5.14 - Fixação do transdutor para medição do deslocamento do laminado 174

Figura 5.15 - Ensaio de caracterização dos laminados 176

Figura 5.16 - Gráfico tensão x deformação dos três corpos de prova 177

Figura 5.17 - Detalhe da fissuração da viga de referência 180

Figura 5.18 - Detalhe da fissuração nas vigas dos grupos $B, C$ e $D$ 181

Figura 5.19 - Curvas força $x$ deslocamento vertical de todas as vigas 185

Figura 5.20 - Deformação no aço 186

Figura 5.21 - Diagrama de momento para um carregamento hipotético 186

Figura 5.22 - Deformação no laminado 187

Figura 5.23 - Curva força $x$ deformação no laminado 189

Figura 5.24 - Curva tensão x deformação no laminado 190

Figura 5.25 - Compatibilização entre as deformações 191

Figura 5.26 - Curvas força $x$ deslocamento vertical das vigas 192

Figura 5.27 - Deslocamento das vigas para cargas pré-determinadas 193

Figura 5.28 - Deslocamentos verticais 194

Figura 5.29 - Curvas tensão de cisalhamento x deslocamento vertical 196 
Figura 5.30 - Curvas tensão de cisalhamento $x$ deslocamento horizontal

Figura 5.31 - Seção transversal das vigas e esquema estático de carregamento

Figura 5.32 - Detalhamento das armaduras das vigas VB 2.1 e VB 2.2 (série I) 201

Figura 5.33 - Esquema de ensaio e detalhamento das vigas da série S1 204

Figura 5.34 - Compósito cimentício sendo incorporado à viga através de "cachimbo" (Adaptado de HELENE,

1992, p.115) 


\section{LISTA DE TABELAS}

Tabela 1.1 - Quantitativo das obras de arte da cidade de São Paulo (Adaptado de SINAENCO, 2005) 31

Tabela 2.1 - Modos de propagação das fissuras 50

Tabela 2.2 - Valores de resistência e módulo de elasticidade para diversos tipos de fibras e matrizes

(FIGUEIREDO, 2000, p. 7) 54

Tabela 2.3 - Tipos e classes das fibras de aço produzidas especificamente para uso em concreto (Adaptado da ABNT NBR 15530: 2007, p. 3) 58

Tabela 2.4 - Principais resultados dos ensaios das vigas ensaiadas (DIAS; BARROS, 2004, p. 5) 76

Tabela 2.5 - Resumo das características das três séries analisadas por Fortes (2004) 78

Tabela 2.6 - Cargas de ruptura obtidas experimentalmente na série S2 81

Tabela 2.7 - Resistências dos concretos (Adaptado de BONALDO et al., 2005, p. 3) 87

Tabela 3.1 - Compósitos analisados (FERRARI, 2007, p.135) 107

Tabela 3.2 - Características das fibras de aço utilizadas na produção dos compósitos 108

Tabela 3.3 - Características das fibras de aço utilizadas no presente trabalho 111

Tabela 3.4 - Traços de concreto ensaiados 112

Tabela 3.5 - Consumo de material para modelagem dos corpos de prova 112

Tabela 3.6 - Resultados médios da caracterização do concreto à compressão e à tração aos 7 dias 114

Tabela 3.7 - Resultados médios da caracterização do concreto à compressão e à tração 115

Tabela 3.8 - Taxas de fibra e microfibra analisadas no trabalho anterior 116

Tabela 3.9 - Taxas de fibra e microfibra analisadas neste trabalho 117

Tabela 3.10 - Consumo de material para produção da matriz cimentícia 123

Tabela 3.11 - Consumo de fibras para produção dos compósitos 123

Tabela 3.12 - Resultados médios dos ensaios de caracterização do concreto à compressão e à tração 125

Tabela 3.13 - Resultados dos parâmetros propostos pela RILEM (2002b) 128

Tabela 4.1 - Nomenclatura dos modelos 140

Tabela 4.2 - Consumo de material utilizado para modelagem dos blocos e corpos de prova 141

Tabela 4.3 - Resultados da caracterização do concreto à compressão e à tração 143

Tabela 4.4 - Propriedades físicas do laminado fornecidas pelo fabricante 143

Tabela 4.5 - Propriedades físicas do laminado obtidas em ensaios de caracterização 146

Tabela 4.6 - Comparação entre as propriedades físicas do laminado 147

Tabela 4.7 - Propriedades da resina fornecidas pelo fabricante 148

Tabela 4.8 - Tensão no laminado e cisalhamento máximos para cada comprimento de ancoragem 159

Tabela 5.1 - Características das vigas principais 163

Tabela 5.2 - Localização e especificação dos equipamentos 172

Tabela 5.3 - Resultados do ensaio de caracterização do concreto usinado 174

Tabela 5.4 - Consumo de material para produção do compósito cimentício 175

Tabela 5.5 - Resultados do ensaio de caracterização do compósito cimentício 175 
Tabela 5.6 - Resultados dos ensaios de caracterização dos laminados 177

Tabela 5.7 - Propriedades da resina Sikadur 30 fornecidas pelo fabricante 178

Tabela 5.8 - Resultados do ensaio de caracterização com o Sikadur ${ }^{\circledast} 30$ 178

Tabela 5.9 - Forças resistidas pelas vigas 182

Tabela 5.10 - Forças resistidas pelas vigas até a deformação limite do aço (10\%) 184

Tabela 5.11 - Deformações máximas nos laminados 188

Tabela 5.12 - Forças resistidas pelas vigas até a deformação admissível do aço 195

Tabela 5.13 - Características das vigas principais (Adaptado de FERRARI, 2007, p.212) 198

Tabela 5.14 - Características das vigas (Adaptado de CASTRO, 2005, p.105) 200

Tabela 5.15 - Características de inserção e caracterização do laminado 202

Tabela 5.16 - Forças e taxas das vigas comparadas 205

Tabela 5.17 - Aproveitamento do laminado das vigas reforçadas 206

Tabela 5.18 - Deslocamento vertical das vigas comparadas 207

Tabela 5.19 - Deslocamento vertical das vigas comparadas 209

Tabela 5.20 - Quantidade de reforço existente nos dois trabalhos 210

Tabela 5.21 - Deformação no reforço 210 


\section{LISTA DE EQUAÇÕES}

Equação 2.1 47

Equação_2.2 48

Equação_2.3 48

Equação_2.4 48

Equação_2.5 60

Equação_2.6 60

Equação_2.7 78

Equação_2.8 89

Equação_2.9 91

Equação_2.10 91

Equação_2.11 91

Equação_2.12 91

Equação_2.13 98

Equação_2.14 99

Equação_2.15 99

Equação_2.16 99

Equação_2.17 101

Equação_2.18 101

Equação_2.19 101

Equação_2.20 102

Equação_2.21 102

Equação_2.22 102

Equação_3.1 119

Equação_3.2 120

Equação_3.3 120

Equação_3.4 120

Equação_3.5 120

Equação_3.6 121

Equação_4.1 146

Equação_4.2 153

Equação_4.3 153

Equação_4.4

Equação_4.5

Equação_4.6

Equação_4.7 156

Equação_4.8 
- 


\section{SUMÁRIO}

1. INTRODUCCÃO 27

1.1. DURABILIDADE DAS Estruturas 29

1.2. TIPOS DE REFORÇOS UTILIZANDO POLÍMEROS REFORÇADOS COM FIBRA DE CARBONO (PRFC) 35

1.3. Objetivos 37

1.4. JUSTIFICATIVA 38

1.5. APRESEnTAÇÃO dA DISSERTAÇÃo 40

2. REVISÃO BIBLIOGRÁFICA 43

2.1. Mecânica do Fraturamento 43

2.1.1. BREVE HISTÓRICO 43

2.1.2. INTRODUÇÃO À MECÂNICA DO FRATURAMENTO 44

2.1.3. Mecânica do Fraturamento Elástica linear (MFEL) 46

2.1.4. Mecânica do Fraturamento Não Linear (MFNL) 46

2.1.5. RILEM 49

2.1.6. Modos de fRATURAMENTO 50

2.2. CONCRETO COM FIBRAS 51

2.2.1. GEOMETRIA DAS FIBRAS 55

2.2.2. TENACIDADE 56

2.2.3. TRABALHABILIDADE 57

2.3. CONCRETO COM FIBRAS DE AÇO 57

2.3.1. DURABILIDADE 61

2.4. ZONA DE TRANSIÇÃO 61

2.4.1. Sílica Ativa 65

2.5. Laminado 68

2.5.1. PRODUÇÃO dAS FIBRAS 70

2.5.2. MATRIZ 71

2.5.3. FATORES CONDICIONANTES 
2.7. REFORÇO COM LAMINADO DE PRFC INSERIDO NO COBRIMENTO DE CONCRETO

2.7.1. TRABALHOS ANTERIORES QUE UtILIZARAM A TÉCNICA NSM 76

2.8. Dimensionamento 97

3. DESENVOLVIMENTO DO COMPÓSITO

3.1. CARACTERIZAÇÃo dos MateriaIS 110

3.1.1. FIBRAS DE AÇO 110

3.1.2. CONCRETO 111

3.2. COMPósIto CIMENTÍCIO de ALTO DeSEMPENHO (CCAD) 116

$\begin{array}{lll}\text { 3.3. } & \text { RILEM TC 162-TDF } & 117\end{array}$

3.4. CONFIGURAÇÃo E REALIZAÇÃo do ENSAIO 121

3.4.1. CARACTERIZAÇÃO DO CONCRETO

$\begin{array}{ll}\text { 3.4.2. ENSAIO } & 126\end{array}$

$\begin{array}{ll}\text { 3.5. Resultados E ANÁLISES } & 127\end{array}$

$\begin{array}{ll}\text { 3.6. CONCLUSÃO } & 137\end{array}$

4. ENSAIO DE ADERÊNCIA 139

4.1. CONFIGURAÇÃo do ENSAIO 139

4.2. CaRACTERIZAÇÃo dos MateriaIS

4.2.1. CONCRETO 141

$\begin{array}{ll}\text { 4.2.2. LAMINADO } & 143\end{array}$

$\begin{array}{ll}\text { 4.2.3. RESINA } & 147\end{array}$

$\begin{array}{ll}\text { 4.3. RealizaÇÃo do ensaio } & 148\end{array}$

4.4. Resultados E ANÁlISES

4.4.1. FORÇA NO LAMINADO 152

4.4.2. TENSÃO DE ADERÊNCIA 156

$\begin{array}{ll}\text { 4.5. CONCLUSÃO } & 160\end{array}$

5. VIGAS PRINCIPAIS 161

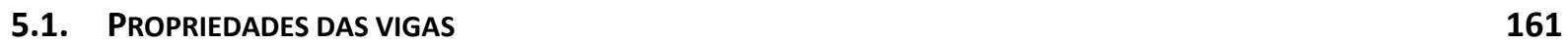

5.2. SISTEMA DE REFORÇO 163

5.3. CONFIGURAÇÃO dO ENSAIO 170 
5.4.1. CONCRETO

5.4.2. COMPÓSITO CIMENTíCIO

5.4.3. LAMINADO

5.4.4. RESINA

178

5.5. Resultados e AnÁlises

5.5.1. MODO DE RUPTURA

5.5.3. DEFORMAÇÕES

5.5.4. DESLOCAMENTO VERTICAL

5.5.5. DESLIZAMENTO DO LAMINADO

5.6. COMPARAÇÃO COM OUTROS TRABALHOS

5.6.1. APRESENTAÇÃO 198

5.6.2. COMPARAÇÃO ENTRE AS TÉCNICAS NSM 204

5.6.3. COMPARAÇÃO COM TRABALHO de FERRARI (2007)

5.7. CONCLUSÃO

5.8. QUESITOS PRÁtICOS

6. CONCLUSÃO 

A reabilitação de estruturas é praticamente tão antiga quanto as próprias estruturas de concreto armado. No caso particular de reforço estrutural, a mudança na carga de utilização, os erros de projeto e construção, as alterações nas normas técnicas e os sinistros levam a uma releitura da capacidade de carga da estrutura. A cada dia cresce a demanda por essas intervenções e também a dificuldade em realizá-las. São vários os métodos e materiais disponíveis no mercado, porém a escolha da combinação mais adequada é que propiciará o sucesso desejado a um custo satisfatório.

Os processos de recuperação mais comuns são: injeção de cimento ou resina epóxi nas fissuras, reforços de elementos estruturais com a utilização de perfis laminados ou concreto armado, reforço utilizando concreto projetado, reforço com adição de cabos de protensão externos e o tradicional reforço mediante colagem de chapas de aço com resina epóxi (BEBER; FILHO; CAMPAGNOLO, 2000). Essa última técnica é certamente uma das mais utilizadas, apresentando como vantagem a simplicidade de execução, o baixo custo e a facilidade de acesso às matérias primas, sem aumento considerável da seção reforçada. Entretanto, estudos demonstram que ao longo do tempo, ocorre corrosão da chapa de aço em sua interface com a resina. Difícil de ser diagnosticada, a patologia prejudica a aderência entre os materiais, o que pode levar o reforço ao colapso. Somado a isso, existe o inconveniente peso das chapas de aço, que dificulta o transporte e a aplicação do sistema de reforço.

Em substituição a esse procedimento, destaca-se o reforço de estruturas com uso de fibras sintéticas. O peso é equivalente a $25 \%$ do peso aço, com resistência aproximadamente nove vezes superior para um mesmo módulo de elasticidade, considerando espessuras iguais. Por não apresentar corrosão, as fibras sintéticas tendem a proporcionar maior durabilidade à estrutura reforçada. Contudo, essa longevidade ainda não pode ser verdadeiramente confirmada devido ao pouco tempo de advento dessa inovação. Atualmente, cerca de cinco mil obras estão sendo monitoradas, garantindo com segurança, vida útil de pelo menos trinta anos, dependendo das condições ambientais e estruturais do reforço (LEAL, 2000).

De todas as fibras sintéticas possíveis de serem utilizadas no reforço de estruturas, destaca-se o sistema polimérico estruturado com fibra de carbono. A grande força de ligação entre os átomos de carbono, associada à sua leveza, faz desse compósito um material altamente promissor. Ele pode ser encontrado em forma de mantas, tecidos, barras e laminados, e é conhecido no meio técnico pela sigla CFRP, do inglês, Carbon Fiber 
Reinforced Polymer ou Polímero Reforçado com Fibra de Carbono (PRFC). É indicado para qualquer elemento estrutural onde são exigidos pouco peso, elevada resistência à tração e corrosão, e necessidade de resistência à fadiga. As características dessa tecnologia incorporam algumas vantagens na execução, como o acréscimo insignificante de carga permanente e espessura mínima. Por ser bastante leve e não necessitar de escoramento há redução do custo com mão de obra e do tempo de paralisação da edificação.

Há muito tempo, esses materiais são empregados nas indústrias aeroespacial e de defesa, nas construções navais, na indústria automotiva, como revestimento de carros de Fórmula 1 e até mesmo na indústria de equipamentos esportivos. Tendo como principal adversário o alto custo de produção, somada a uma certa carência de pesquisas, houve um atraso de sua inserção no mercado da construção civil. Porém, com o barateamento das matérias-primas e dos custos industriais de manufatura, esses materiais passaram a ficar mais competitivos e também mais conhecidos, gerando uma nova linha de pesquisa e consequentemente um maior consumo pelos engenheiros, que ficaram mais confiantes em utilizar o novo recurso.

Os japoneses, incentivados pelo governo, foram os precursores dessa técnica por estarem preocupados com as consequências nas estruturas de concreto armado causadas pelos abalos sísmicos que frequentemente ocorrem no arquipélago. O objetivo era desenvolver processos destinados não somente a recuperar rapidamente as estruturas danificadas, como também prevenir, através do aumento de resistência, os problemas estruturais. Com isso, garantir-se-ia que importantes estruturas do sistema viário permanecessem utilizáveis em situações de emergência, como também, caso fossem ainda assim danificadas, pudessem ser recuperadas prontamente. Sendo assim, muitas pesquisas foram realizadas e muitas informações adquiridas, principalmente após a ocorrência do terremoto de Kobe, em 1995. Nessa ocasião, centenas de estruturas de concreto armado foram reforçadas com fibras de carbono e muitas delas monitoradas para fornecerem dados relativos ao desempenho estrutural desse sistema com o passar do tempo.

Um dos processos utilizados pelos japoneses é o reforço das cabeças dos pilares com a fibra de carbono para enrijecer os nós das estruturas, evitando assim a liquefação, que é o efeito causado pelo abalo sísmico. Atualmente o reforço é colocado também em estruturas novas para evitar que estas venham a ruir em virtude de abalos.

Desde então, a técnica chegou à Europa e aos Estados Unidos e hoje é encontrada em todo o mundo. Alguns países, como o Canadá, os Estados Unidos e o próprio Japão, já 
criaram normas específicas para elaboração de projetos utilizando as fibras de carbono. No Brasil, a demora na elaboração de regulamentos próprios faz com que os profissionais ainda recorram a essas normas estrangeiras.

\subsection{Durabilidade das Estruturas}

De acordo com a ABNT NBR 6118 (2003), todos os processos que envolvem a utilização de uma estrutura, desde sua concepção em projeto à sua execução, devem objetivar a capacidade resistente, o desempenho em serviço e a durabilidade. Para que isso seja possível, alguns critérios devem ser definidos entre o engenheiro calculista e o proprietário da obra na intenção de aumentar a vida útil da estrutura. Dados como condições ambientais, finalidade de uso da estrutura e condições de manutenção devem ser considerados. Por se tratar de um acordo entre as partes, o engenheiro deve estar habilitado a buscar a melhor solução estrutural, garantindo a segurança e a durabilidade à obra, ao passo que o proprietário deve garantir o cumprimento de todas as exigências feitas pelo profissional. Problemas com a qualidade dos materiais ou de execução devem ser arcados pelo proprietário (LEAL, 2000).

A mesma norma, no item 6.2.1, entende por vida útil de um projeto "o período de tempo durante o qual se mantêm as características das estruturas de concreto, desde que atendidos os requisitos de uso e manutenção prescritos pelo projetista e pelo construtor". O conceito de vida útil pode ser aplicado à estrutura como um todo ou às suas partes, conforme relata a norma. Sendo assim, durante o período de utilização, peças isoladas podem merecer atenção especial, sobretudo quando há alteração de algum dos critérios usados durante a concepção da estrutura ou mesmo quando ocorre algum dano acidental.

Parece exagero imaginar que logo após a entrega de uma obra deva iniciar-se as vistorias periódicas em todos os itens de uma construção. Esse hábito, embora não muito comum, é importante para detectar problemas ainda no início e com isso, diminuir custos referentes aos reparos e reforços. A ABNT NBR 5674 (1999) comenta que estudos realizados em diversos países, para diferentes tipos de edificações, demonstram que os custos anuais envolvidos na operação e manutenção de edificações em uso, variam entre 1 e $2 \%$ do custo inicial da obra. Num primeiro momento parece pouco, mas o acúmulo desse valor ao longo da vida útil da edificação pode igualar ou até mesmo superar o custo inicial da obra. Mesmo assim é um investimento bastante justificável ao se imaginar todos os problemas sociais envolvidos na interdição, demolição ou até mesmo num acidente com ou sem vítimas. 
Denomina-se terapia o tratamento realizado para restabelecer as condições mínimas de segurança de uma estrutura danificada. Para Beber, Filho e Campagnolo (2000), a terapia consiste na recuperação total ou parcial da estrutura, mediante reforço dos elementos comprometidos. Beber (2009) diz que atualmente, o desafio da indústria da construção civil é renovar a infra-estrutura do país, respeitando as enormes restrições econômicas. Em termos econômicos e ambientais, é muito mais viável reabilitar estruturas e edificações que demolilas. Porém, o descaso dos órgãos públicos durante muitos anos dificulta e deixa ainda mais onerosa a reabilitação das estruturas, sobretudo das obras de arte e patrimônios históricos.

Um exemplo bastante comum da falta de atenção com as estruturas são as pontes das rodovias brasileiras. Construídas há cerca de 50 anos e sem investimentos aplicados durante sua vida útil, hoje elas se encontram bastante ultrapassadas em relação às cargas transportadas. O professor da Universidade Federal do Paraná (UFPR), Mauro Lacerda, em entrevista a Nakamura (2009) da Revista Téchne lembra que "normas internacionais consideram que a vida útil dessas construções deve estar ao redor de 50 anos, portanto nossas pontes estão entrando no limite". O Engenheiro do CREA-PR, Claudimor Faé, em entrevista à mesma revista, diz que as pontes, então chamadas por obra de arte, foram construídas para suportar 30, 40 tf de carga, mas hoje estariam recebendo até 70 tf.

De suma importância para a economia brasileira, esse tipo de obra opera hoje no limite da estabilidade e da segurança. Uma pesquisa do Centro de Estudos em Engenharia Civil da UFPR verificou que no estado, as inspeções de pontes são feitas em prazos máximos de dez anos, quando normas internacionais recomendam inspeções rotineiras a cada dois anos.

O que se vê são sucessivos acidentes, sendo alguns de muita gravidade, como o ocorrido em janeiro de 2005 na principal ligação entre São Paulo e o Sul do país, na rodovia Régis Bittencourt. No local, existem duas pontes, com duas faixas cada uma, que passam sobre o rio Capivari, em Campina Grande do Sul (PR). Uma das pontes opera no sentido Curitiba e a outra, no sentido São Paulo. Com a chuva, o sistema de drenagem não conseguiu escoar o volume de água e a infiltração no solo, provocou deslizamento de terra, que acarretou o deslocamento dos pilares da estrutura. Cerca de $50 \mathrm{~m}$ do trecho da ponte no sentido a São Paulo desmoronou e a no sentido Curitiba cedeu. Uma pessoa morreu e três ficaram feridas. Circulavam pelo local cerca de 30 mil veículos por dia. 

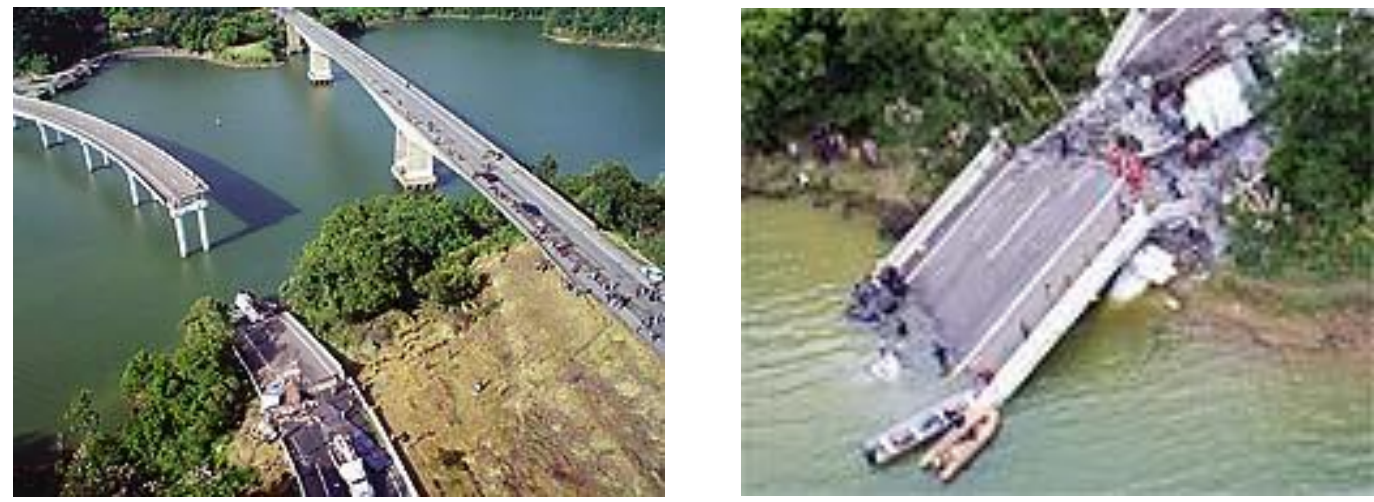

Figura 1.1 - Desmoronamento da ponte sobre o rio Capivari em janeiro de 2005

O Sindicato da Arquitetura e da Engenharia de São Paulo (Sinaenco), lançou em junho de 2005 a "Campanha pela manutenção do ambiente construído" com o objetivo de defender a manutenção permanente da infra-estrutura das cidades. Por meio de estudos que apontaram para a atual situação de empreendimentos como pontes e viadutos, o sindicato detectou o "prazo de validade" dessas obras, "buscando alertar a sociedade sobre o estado de deterioração da infra-estrutura urbana, que sofre com a falta de uma política preventiva que preserve as obras-de-arte das cidades" (SINAENCO, 2005).

Foi elaborado um relatório com alguns exemplos de obras deterioradas que foram analisadas por engenheiros especialistas de empresas associadas ao sindicato. Deve-se lembrar que muitas dessas obras datam do início do século XX. De acordo com o relatório, a cidade de São Paulo apresenta (Tabela 1.1):

Tabela 1.1 - Quantitativo das obras de arte da cidade de São Paulo (Adaptado de SINAENCO, 2005)

\section{OBRAS DE ARTE}

\begin{tabular}{l|l}
\hline Pontes e viadutos & 240 \\
\hline Passarelas & 75 \\
\hline Pontilhões & 700 \\
\hline
\end{tabular}

VALOR ESTIMADO EM BILHÕES DE REAIS

\begin{tabular}{|c|c|}
\hline Pontes e viadutos & 6,7 \\
\hline Passarelas & 0,28 \\
\hline Pontilhões & 1,05 \\
\hline Total & $\mathrm{R} \$ 8,03$ bilhões \\
\hline $\begin{array}{l}\text { DESPESAS COM MANUTENÇÃO NOS } \\
\text { ÚLTIMOS QUATRO ANOS (2001 a 2004) }\end{array}$ & $\begin{array}{c}\mathrm{R} \$ 30 \text { milhões/ano }(0,33 \% \text { do } \\
\text { total })\end{array}$ \\
\hline
\end{tabular}


Capítulo 1 - Introdução

Na Figura 1.2, encontram-se alguns exemplos da situação das pontes da cidade de São Paulo:

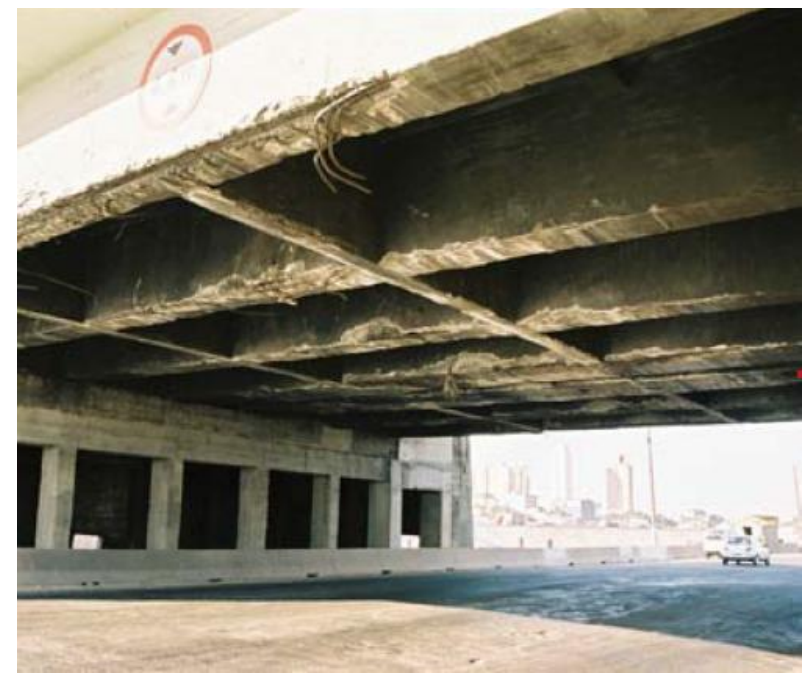

a) Ponte do Limão: barras de aço expostas

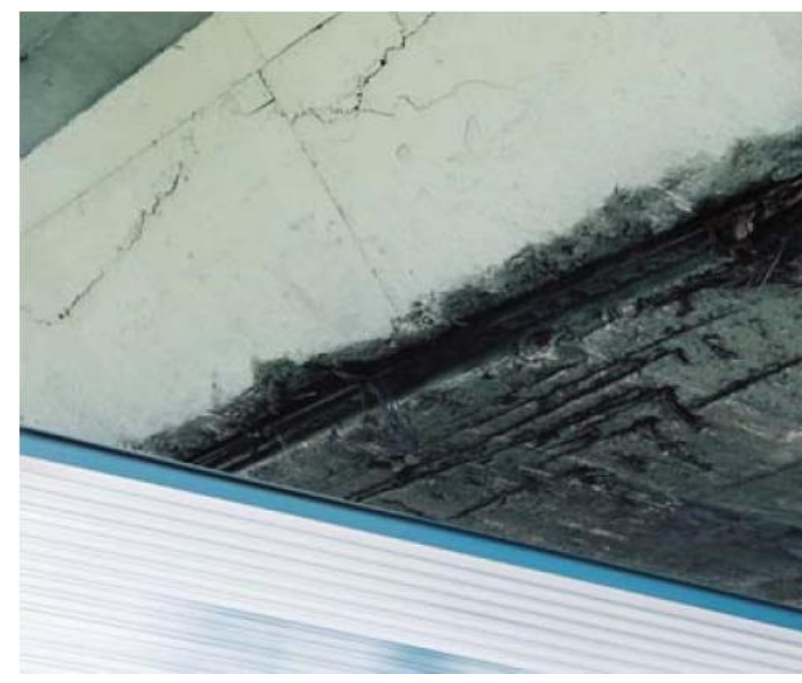

c) Viaduto Santo Amaro: armaduras expostas pelos choques dos caminhões

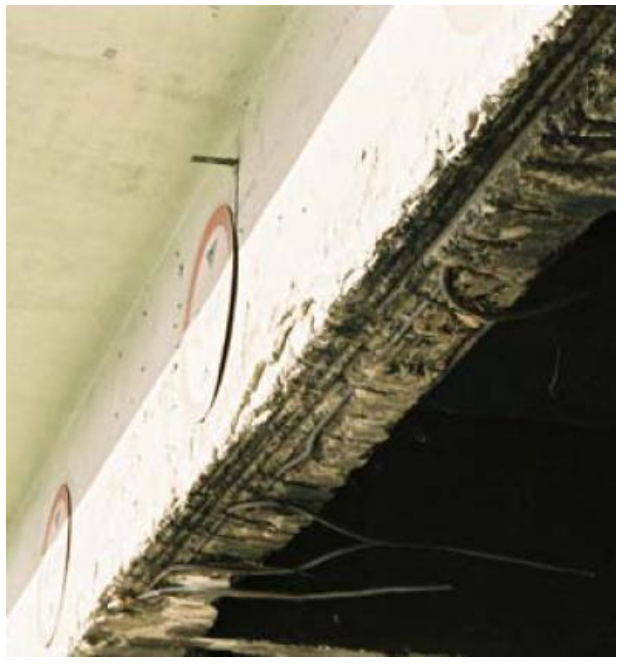

b) detalhe das armaduras expostas na Ponte do Limão

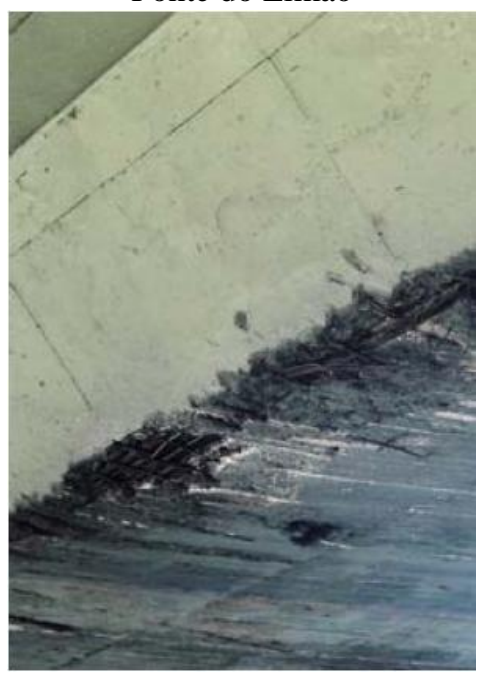

d) detalhe das armaduras expostas no Viaduto Santo Amaro

Figura 1.2 - Situação das pontes da cidade de São Paulo (Adaptado de SINAENCO, 2005)

Nas rodovias, algumas empresas concessionárias estão atentas ao problema. $\mathrm{O}$ Consórcio Nova Dutra e a Agência Nacional de Transportes Terrestres anunciaram investimentos de $\mathrm{R} \$ 200$ milhões para o ano de 2010, sendo $\mathrm{R} \$ 26$ milhões destinados à recuperação de pontes e viadutos.

A Centrovias Sistemas Rodoviárias S.A. também vem realizando investimentos no setor. Em 2005, realizou o reforço do viaduto que liga as cidades de Analândia a Itirapina, no 
interior paulista, com o objetivo de atualizar a condição da estrutura às normas vigentes. $\mathrm{O}$ viaduto construído em meados da década de 1970 apresentava quadro de fissuração generalizada na face inferior da laje e necessitava de reforço estrutural para atender às condições do trem-tipo da classe 45.

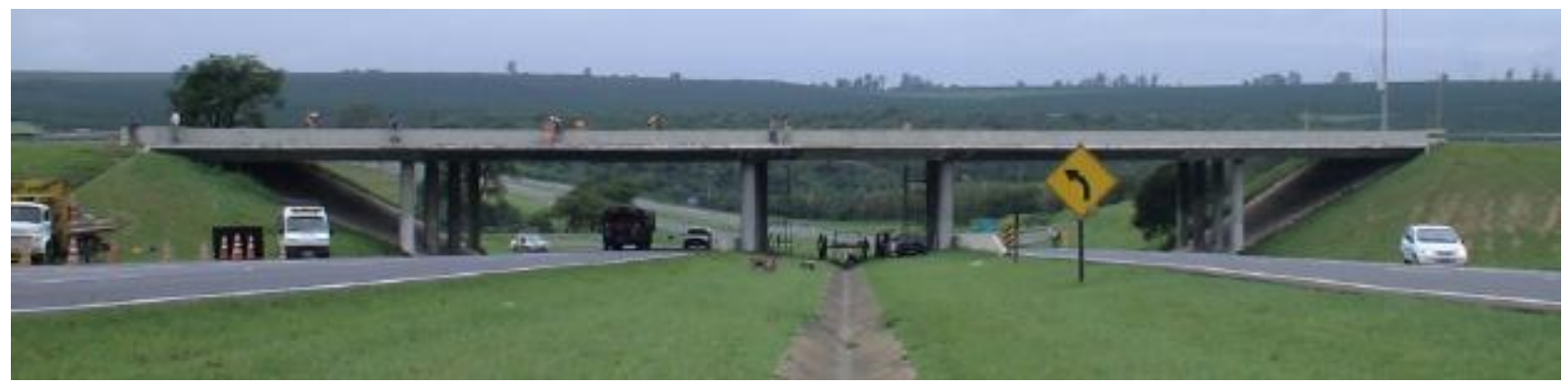

Figura 1.3 - Vista do viaduto O.A.E. que liga Analândia à Itirapina

Foi elaborado um projeto de reforço estrutural, que consistiu na execução de sobrelaje em toda a extensão do tabuleiro e aplicação de reforço de polímero reforçado com fibra de carbono (PRFC) na face inferior dos dois tramos maiores.
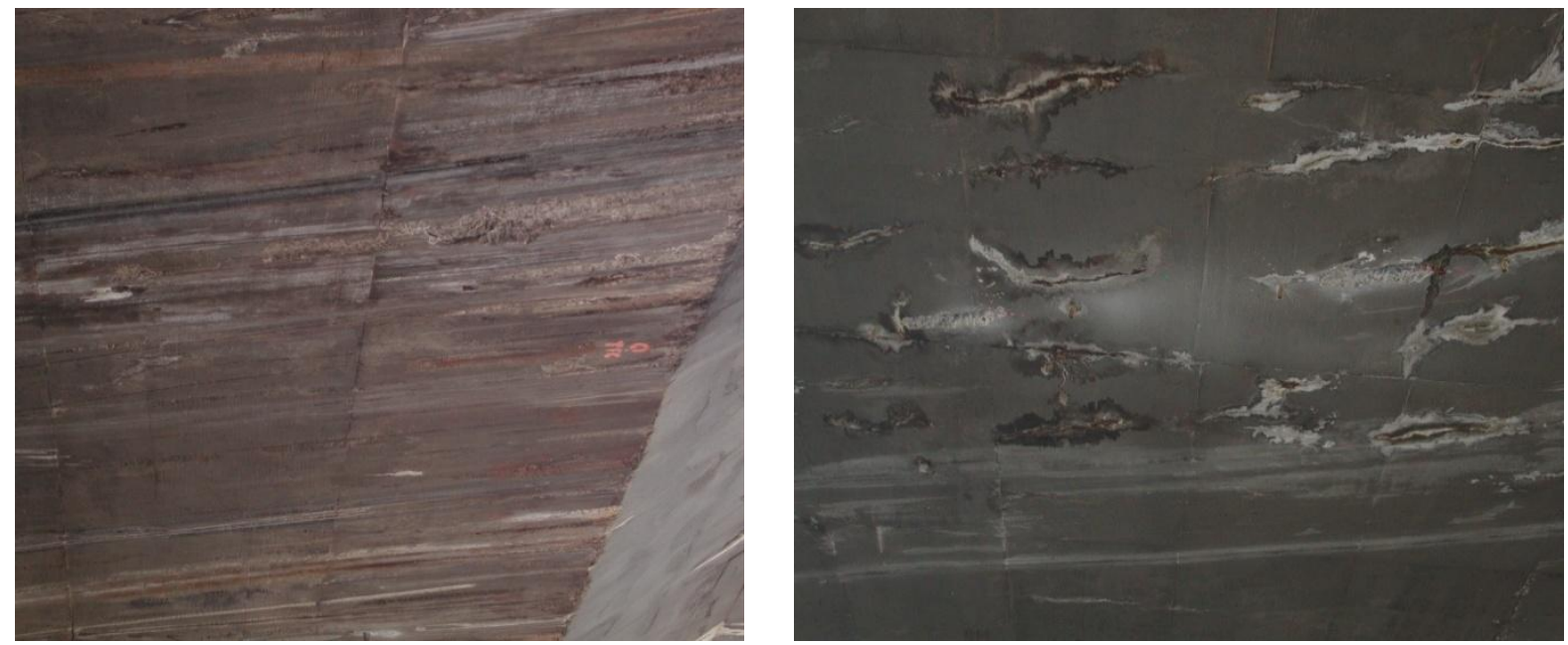


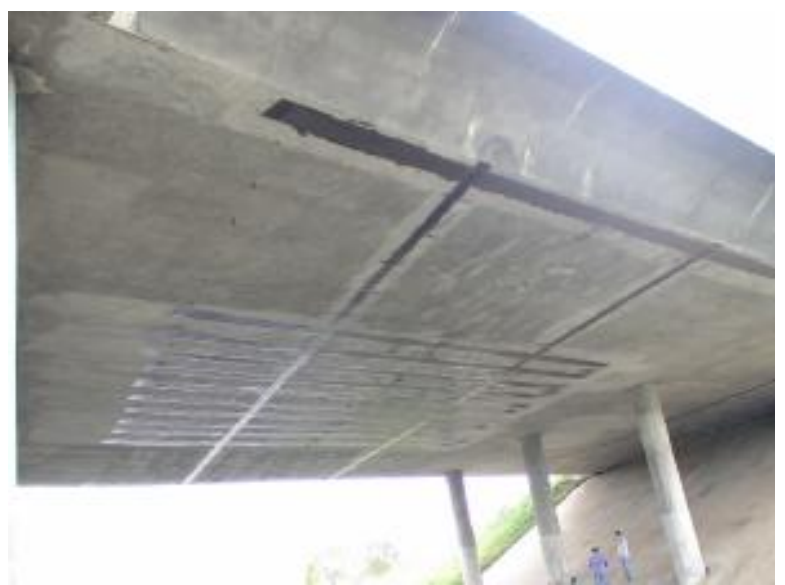

Figura 1.4 - Situação do viaduto antes (acima) e após (abaixo) recuperação e reforço

Analisando os resultados dos ensaios estáticos e dinâmicos realizados antes e depois do reforço, concluiu-se que o objetivo foi atingido.

Problemas de abandono também são bastante frequentes nos edifícios tombados pelo patrimônio histórico, com o agravante de que nem toda solução construtiva pode ser utilizada de forma a manter às características e identidade originais da obra.

Por definição, "patrimônio histórico é um bem material, natural ou imóvel que possui significado e importância artística, cultural, religiosa, documental ou estética para a sociedade" (MONUMENTA, 2009). Como esses patrimônios foram construídos ou produzidos pelas sociedades passadas, e representam uma importante fonte de pesquisa e preservação cultural, há uma preocupação mundial em proteger e restaurar essas obras, expressa em leis que possibilitam a manutenção das características originais. Quando um imóvel é tombado por algum órgão do patrimônio histórico, ele não pode ser demolido, nem mesmo reformado, apenas passar por um processo de restauração seguindo normas específicas.

No Brasil, existe o Programa Monumenta, que é um programa estratégico do Ministério da Cultura. Segundo o Ministério (2009), seu conceito é inovador e procura conjugar recuperação e preservação do patrimônio histórico com desenvolvimento econômico e social. Ele atua em cidades históricas protegidas pelo Instituto do Patrimônio Histórico e Artístico Nacional (IPHAN).

O interessante nesse programa, é que seus componentes não se limitam à restauração isolada de monumentos, mas têm a intenção de criar ou resgatar seu valor de uso produtivo, para fins residenciais e comerciais, em modalidades compatíveis. 
Um exemplo desse tipo de obra é o viaduto de Santa Teresa, localizado em Belo Horizonte - MG. Com extensão total de 397 m, foi construído em 1927 e em 1998 teve de ser reforçado para se adequar às novas exigências da cidade, com a ressalva de que não poderia haver mudanças em suas dimensões. Para atender a essa exigência, foi utilizado o sistema PRFC pela primeira vez na América do Sul, como mostra a Figura 1.5:

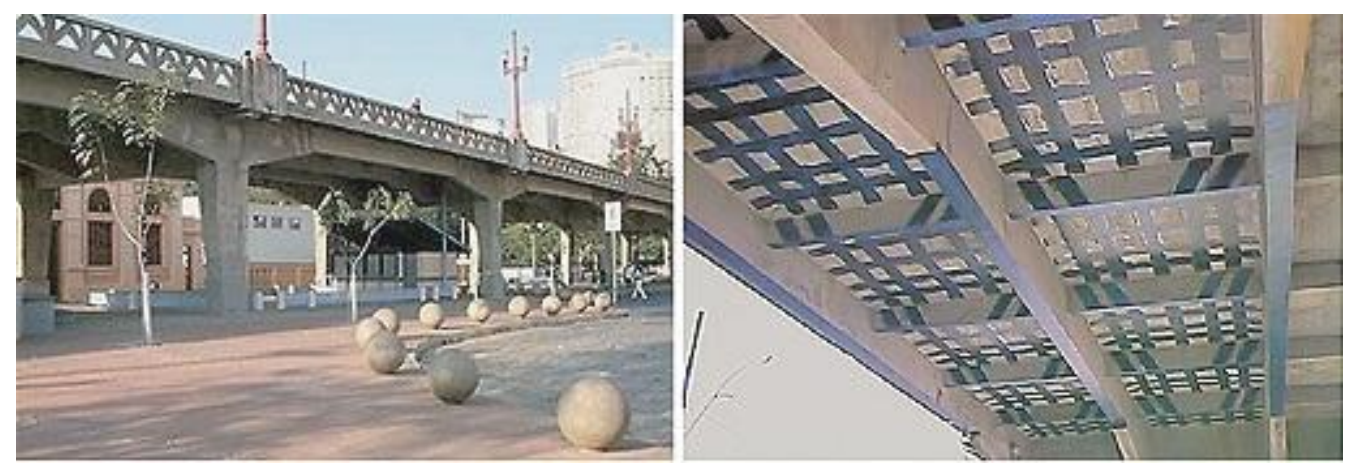

Figura 1.5 - Reforço do viaduto de Santa Teresa em Belo Horizonte - MG.

Após o acabamento final, o viaduto atualizou sua capacidade de carga com poucos milímetros de espessura, sem perder a identidade.

\subsection{Tipos de reforços utilizando polímeros reforçados com fibra de carbono (PRFC)}

Para reforço e reabilitação de estruturas, é possível recorrer às diversas formas dos PRFC disponíveis no mercado. São barras, laminados, mantas e tecidos, que podem reforçar estruturas ao cisalhamento e à flexão, através de técnicas como aderência externa e aderência interna, além dos cabos pós-tensionados e não aderentes.

A configuração geométrica do PRFC deve estar em conformidade com os esforços a serem combatidos. Por isso, os polímeros podem ser classificados sob três sistemas distintos:

- Sistema Unidirecional: nesse sistema, o reforço, atuando em conjunto com o concreto e o aço, deve trabalhar em estruturas lineares. Fazem parte desse sistema, as barras, os fios, os cabos e os laminados;

- Sistema Bidirecional: como o próprio nome sugere, o reforço atua no aumento de capacidade resistente segundo duas direções quaisquer contidas no mesmo plano. São 
exemplos, os reforços de lajes e tabuleiros de pontes reforçados com mantas ou grelhas de barras de PRFC;

- Sistema Espacial ou Multidirecional: mais raro, esse sistema é resultado da combinação dos dois sistemas anteriores. É indicado para estruturas mais complexas com geometria e comportamento tridimensionais.

Os PRFC podem ainda ser classificados em sistemas pré-fabricados ou sistemas curados "in situ". Os sistemas pré-fabricados, como por exemplo, os laminados, se apresentam totalmente curados e possuem as propriedades de um material industrializado, ou seja, seção e rigidez definidas. Já os sistemas curados "in situ", são compostos por um emaranhado de fibras, dispostas como manta ou como tecido, que recebem a resina para compor o polímero no momento de sua aplicação. Por isso, suas características não são bem definidas. A vantagem em relação ao laminado é a flexibilidade do material, que permite a aplicação em estruturas das mais variadas formas.

A técnica de reforço mais conhecida utilizando PRFC, é a aderência externa de mantas, tecidos e laminados. Porém, o principal problema encontrado é a falta de resistência do concreto à tração e ao cisalhamento, o qual provoca o desprendimento do reforço antes de atingir o aproveitamento máximo do material. Essa ruptura do reforço, designada por "peeling", pode se dar entre o material de reforço e a resina, entre a resina e o concreto ou ainda com o destacamento do concreto de cobrimento (Figura 1.6). Além disso, o posicionamento do reforço na face do elemento estrutural tem como inconveniente a necessidade de proteção contra fogo, raios ultravioleta e vandalismo.

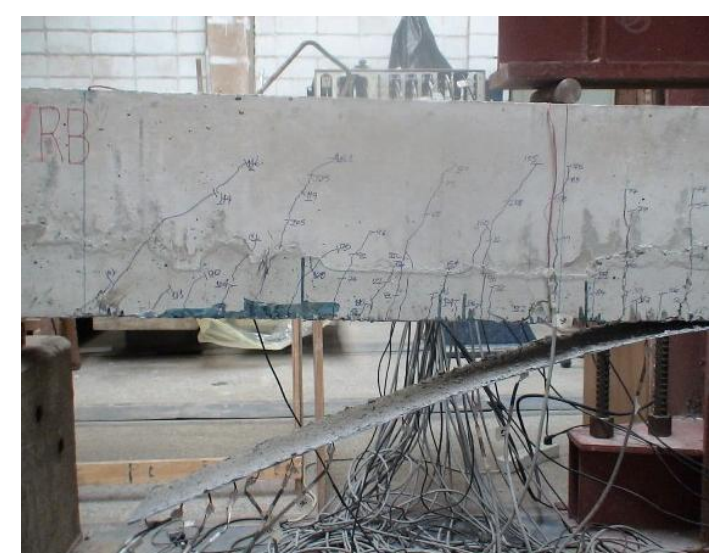

Figura 1.6 - Detalhe de ruína de viga reforçada com aderência externa de manta (Adaptado de FERRRI, 2007, p.245) 
A proposta dessa pesquisa trabalha justamente para que haja aproveitamento total do reforço sem seu destacamento. Por isso, estuda a técnica conhecida por Near Surface Mounted (NSM), que na livre tradução quer dizer instalação em abertura próxima à superfície. Nesse caso, o laminado é inserido em um entalhe realizado no concreto de cobrimento do elemento estrutural (Figura 1.7). Com dupla área de contato, o laminado possui maior zona de aderência e com isso, diminui tensões de tração e cisalhamento no concreto situado na região de ancoragem. Outra vantagem da técnica é que o laminado, por possuir orientação unidirecional das fibras, potencializa a resistência e a rigidez na direção longitudinal.

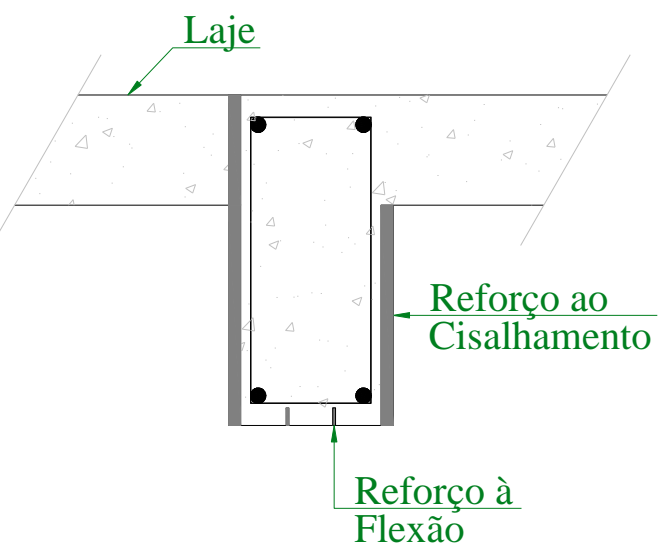

Figura 1.7 - Sistema de reforço à flexão e ao cisalhamento através da técnica NSM

Atualmente, os laminados são fixados ao concreto por intermédio de um adesivo epóxi. Por ficarem quase imperceptíveis após o acabamento final, são indicados para recuperação dos patrimônios históricos.

\subsection{Objetivos}

A presente pesquisa propõe o estudo e a divulgação do reforço à flexão de vigas de concreto armado com uso da técnica NSM, associando a ela um processo de preparação do substrato com um compósito cimentício de alto desempenho.

Nem sempre o concreto que constitui a viga a ser reforçada - especialmente a região tracionada onde será inserido o reforço - apresenta características satisfatórias para receber o laminado. Concreto de baixa resistência ou deteriorado é facilmente encontrado em estruturas 
mais antigas, obrigando o reparo da viga antes de receber o reforço. É nesse momento que se propõe a utilização de um compósito reforçado com fibras e microfibras de aço na região tracionada da viga. Essa inovação construtiva foi primeiramente estudada por FERRARI (2007), que reforçou à flexão vigas de concreto armado com manta de PRFC. Diante dos bons resultados em termos de resistência e rigidez, houve a motivação de se estudar a inovação construtiva associada à técnica NSM.

Sendo assim, o presente trabalho tem como objetivos específicos, associados à metodologia de pesquisa:

- o desenvolvimento de um compósito cimentício com fibras e microfibras de aço, que apresente resistência ao fraturamento antes e após o início do processo de fissuração do concreto;

- estudar o processo de transferência de tensões do laminado ao concreto na zona de ancoragem;

- analisar o comportamento das vigas reforçadas segundo a técnica NSM, sob três maneiras distintas de ancoragem do laminado, utilizando a reconstituição da face tracionada com o compósito reforçado com fibras e microfibras de aço.

\subsection{Justificativa}

O reforço de elementos estruturais com PRFC tem se tornado cada vez mais acessível. Porém em muitos países, assim como no Brasil, ainda não existe uma norma específica que regulamente o reforço com PRFC, tanto na forma de tecido quanto de laminado. Por isso, os profissionais têm que recorrer às normas estrangeiras e aplicar nos produtos disponíveis no país. Além disso, os vários trabalhos sobre o assunto apresentam conclusões díspares, dificultando o entendimento da técnica.

O presente trabalho, além de complementar a proposta elaborada por Ferrari (2007), compara os resultados obtidos com trabalhos realizados por outros autores, buscando unificar as conclusões.

Ferrari (2007) ao idealizar o compósito cimentício reforçado com fibras e microfibras de aço, imaginou criar um material que melhorasse a transferência de esforços entre o reforço de PRFC e a viga, melhorando as condições de adesão da manta de PRFC e controlando o 
processo de fissuração que culmina no desprendimento do reforço. Para isso, foram estudadas duas formas de ancoragem distintas como podem ser vistas na Figura 1.8:
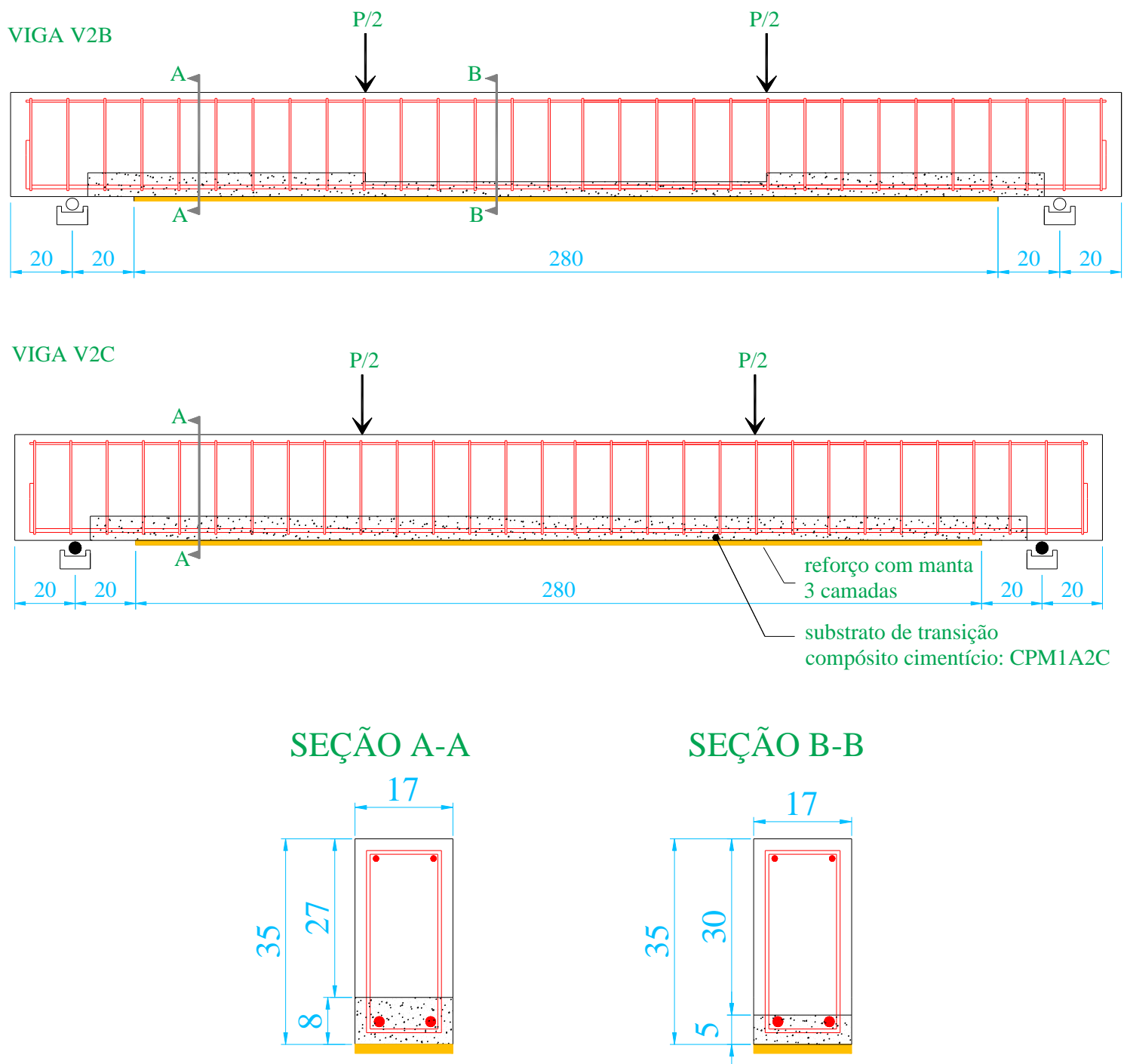

Figura 1.8 - Configuração do ensaio realizado por Ferrari (2007) com reconstituição da face tracionada da viga (Adaptado de FERRARI, 2007, p.214)

Comparando os resultados obtidos em ensaio à flexão a quatro pontos entre as vigas reforçadas e a viga de referência (sem reforço), Ferrari (2007, p.299) concluiu que

[...] a reconstituição prévia do banzo tracionado com um compósito cimentício de alto desempenho à base de macro e microfibras de aço evita a rápida propagação de fissura crítica na extremidade do reforço e retarda o desprendimento prematuro da manta. Com a presença de um material de maior resistência ao fraturamento no banzo tracionado da viga, as fissuras são mais distribuídas e de menor abertura ao longo da extensão do reforço. 
O uso de fibras de aço associadas à manta de PRFC proporcionou um expressivo aumento na resistência final (até 120\%) e na rigidez da viga (até 67\%) em comparação com a viga de referência.

Diante de resultados tão expressivos e como forma de complementar o estado da arte sobre reforço com PRFC, manteve-se nesse trabalho, o uso do compósito cimentício aplicado na face tracionada da viga. O desenvolvimento de um novo compósito cimentício reforçado com fibras e microfibras de aço, também faz parte do presente trabalho. Embora Ferrari (2007) tenha obtido resultados satisfatórios com o compósito desenvolvido por ele, acreditase que há como melhorar os resultados obtidos em termos de capacidade de carga do reforço e resistência à iniciação e propagação de fissuras no concreto.

\subsection{Apresentação da dissertação}

Este trabalho está dividido em seis capítulos, descrevendo a preparação, o desenvolvimento e os resultados obtidos na pesquisa. São eles:

- Capítulo 1 - Introdução: faz-se uma breve apresentação do tema, discorrendo sobre a importância de se cuidar das estruturas de concreto armado, a descrição das técnicas mais comuns de reforço e a atual situação da técnica de reforço com uso de polímeros reforçados com fibra de carbono. Apresenta-se também a justificativa e os objetivos da pesquisa.

- Capítulo 2 - Revisão Bibliográfica: neste capítulo sintetiza-se os conhecimentos relatados por outros autores nos temas aqui abordados.

- Capítulo 3 - Desenvolvimento do Compósito: sob o enfoque da Mecânica do Fraturamento, é desenvolvido experimentalmente o compósito cimentício com fibras e microfibras de aço, que cuja função é servir como substrato de transição entre o concreto existente da viga e o reforço com PRFC.

- Capítulo 4 - Ensaio de Aderência: discute-se o ensaio à flexão realizado em blocos de concreto não armado para estudo do comportamento da ligação entre o laminado, a resina e o concreto.

- Capítulo 5 - Vigas Principais: apresenta-se o programa experimental desenvolvido para realização do ensaio das vigas principais reforçadas sob três distintas maneiras de ancoragem do laminado. São apresentados e discutidos os resultados obtidos, assim como comparados com os resultados de outras pesquisas. 
Capítulo 1 - Introdução

- Capítulo 6 - Conclusão: apresenta-se as principais conclusões da pesquisa e sugestões para trabalhos futuros. 



\subsection{Mecânica do Fraturamento}

\subsubsection{Breve histórico}

A Mecânica do Fraturamento aplicada ao concreto é uma técnica relativamente nova quando comparada a outros materiais estruturais. Segundo Mehta e Monteiro (2008), a teoria da Mecânica do Fraturamento Elástica Linear foi desenvolvida em 1920, mas apenas 41 anos depois que se realizou o primeiro ensaio experimental com concreto. Enquanto isso, muitos materiais frágeis e metálicos já eram estudados sob esse enfoque. Avanços importantes para o concreto só ocorreram em 1971, quando pesquisadores desenvolveram modelos mecânicos de fratura não linear, considerando o comportamento da estrutura combinado ao comportamento do concreto.

A primeira pesquisa experimental sobre a Mecânica do Fraturamento no concreto foi realizada por Kaplan em 1961 e determinou a tenacidade de amostras de diferentes tamanhos. Por definição, tenacidade é o termo utilizado para descrever a habilidade de um dado material deformar-se plasticamente, absorvendo energia antes e durante o processo de ruptura (FERREIRA, 2002). Assim, quanto menos energia o material absorver, mais frágil será sua ruptura.

Estudos experimentais subsequentes indicaram que a tenacidade ao fraturamento é diretamente proporcional ao volume, dimensão máxima e rugosidade do agregado, e é inversamente proporcional ao aumento da relação água/aglomerante e ao aumento do teor de ar.

Mehta e Monteiro (2008) dizem que A.A. Griffith é reconhecido como o fundador da mecânica do fraturamento. Ele quebrou o paradigma de que, teoricamente, a resistência à abertura de fissuras era independente do tamanho da imperfeição encontrada nos materiais. A solução veio através da abordagem de um novo equilíbrio de energia, que somava os termos já consagrados (energia potencial das cargas externas e energia de deformação elástica armazenada) ao novo termo chamado de energia de superfície. Essa solução inaugurou a Mecânica do Fraturamento Não Linear. Porém, o método ainda apresentava erro porque não considerava a energia absorvida para a propagação da fissura. Mehta e Monteiro (2008) 
acrescentam que Irwin foi quem propôs essa correção através da quantificação do trabalho necessário para produzir um aumento unitário na área de fissuração, denominada taxa crítica de liberação de energia ou energia de fraturamento $\left(G_{F}\right)$. Essa taxa é obtida experimentalmente e pressupõe-se que é uma propriedade do material, embora alguns autores discordem alegando que o efeito de escala do corpo de prova pode alterá-la (MILLER, 2008). Com a taxa, é possível determinar se uma fissura irá ou não se propagar sob qualquer condição de carga. $O$ processo é bastante simples: primeiro calcula-se a energia de fraturamento $(G)$ e compara-se ao valor de $G_{F}$. Se a taxa de liberação for menor que a taxa crítica $\left(G<G_{F}\right)$, a fissura é dita estável, caso contrário, haverá propagação da abertura.

Em estruturas já existentes, a Mecânica do Fraturamento auxilia na previsão de catástrofes, com o estudo da propagação de fissuras sob determinada carga. Mehta e Monteiro (2008) dão exemplo do estudo de fissuras em barragem de concreto. Analisando o cenário existente, pode-se verificar a gravidade do problema quando a carga solicitar a tensão de tração última do concreto. É possível verificar se haverá ou não propagação dessas fissuras e quais as consequências que trarão à estabilidade da estrutura.

\subsubsection{Introdução à mecânica do fraturamento}

Para Souza (2001, p. 7), Mecânica do Fraturamento é uma disciplina da Engenharia que "relaciona a presença de defeitos, como fissuras, com a capacidade de estruturas e materiais suportarem carregamentos". Esses defeitos podem ser provenientes de qualquer etapa do processo de construção: concepção, execução ou utilização.

Referindo-se à concepção, do ponto de vista da média escala, o concreto é um material bifásico, composto por agregado e argamassa. Na ligação das fases, conhecida como zona de transição, é onde ocorrem as primeiras degradações de natureza irreversível. Isso porque o agregado, que representa a fase estável do concreto, é envolto por argamassa, que sofre variações volumétricas desde seu processo de cura (retração, por exemplo), desligando-se do agregado e formando vazios (PROENÇA; PITUBA, 2000). Além disso, a fase composta por argamassa é constituída por poros cuja quantidade depende de fatores como relação água/cimento e vibração durante a moldagem dos elementos estruturais.

Os poros, tanto na argamassa como na zona de transição, assim como mudanças bruscas na geometria dos elementos estruturais, proporcionam uma descontinuidade e fazem com que as linhas de fluxo de carga desviem seu percurso normal, aproximando-se umas das 
outras e gerando concentração de tensões que são decisivas na análise de problemas de fraturamento (Figura 2.1).

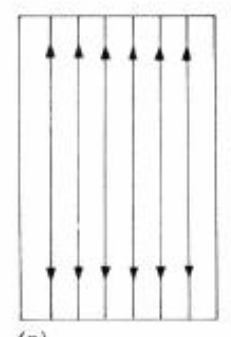

(a)

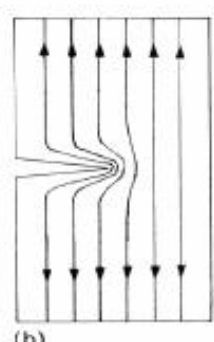

(b)

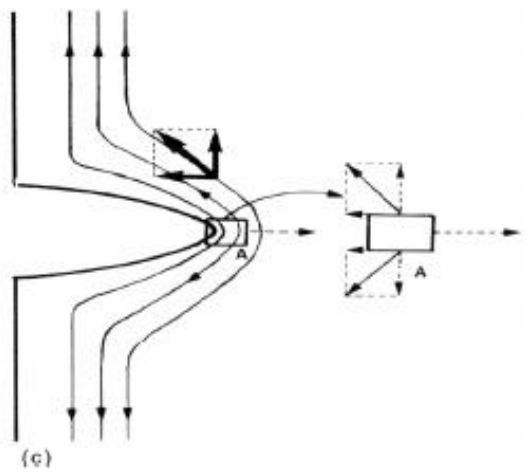

Figura 2.1 - Linhas de fluxos de tensões em uma placa submetida a carregamento uniforme (SOUZA, 2001, p. 39)

O campo de tensões localizado à frente da ponta da fissura é denominado fator de intensidade de tensão $(K)$ e é ele quem delimita a região conhecida como região de domínio de K. Miller (2008) acrescenta que $K$ é função do carregamento externo, das dimensões do corpo fissurado, da extensão da fissura e da vinculação.

É na região de domínio de $K$ que se encontra a zona de fraturamento ou de processos inelásticos, cujas dimensões são preponderantes para a escolha do método a ser aplicado ao corpo fissurado (Figura 2.2). Ferreira (2002) explica que a Mecânica do Fraturamento pode ser dividida em elástica linear (MFEL) e não linear (MFNL). O primeiro grupo inclui os materiais frágeis, com plastificação em pequena escala, e o segundo inclui elasticidade não linear, fraturamento elastoplástico e fraturamento quase frágil, como ocorre com o concreto. 


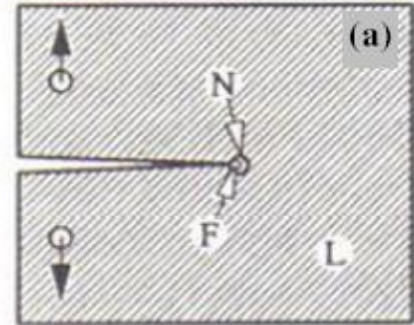

a) material elástico linear

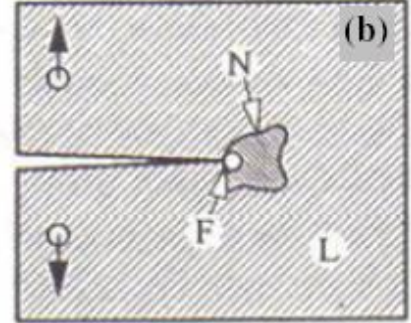

b) material plástico não-linear

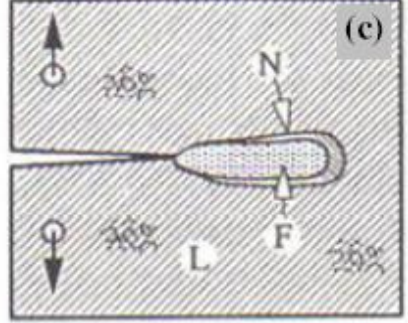

c) material quase frágil não linear

$\mathrm{L}$ representa a região elástica linear, $\mathrm{N}$ a região microfissurada e $\mathrm{F}$ a zona de fraturamento ou de processos inelásticos

Figura 2.2 - Área de danificação à frente da ponta da fissura em materiais distintos (MILLER, 2008, p. 43)

\subsubsection{Mecânica do Fraturamento Elástica Linear (MFEL)}

A Mecânica do Fraturamento Elástica Linear considera o material elástico, homogêneo e isotrópico, seguindo a lei de Hooke. O método pode ser utilizado quando a zona de processos inelásticos (zona de fraturamento) é muito pequena em comparação com as demais dimensões do corpo, podendo ser desprezada.

No caso do concreto é observada uma zona inelástica de grandes dimensões à frente da fissura, impedindo, em muitos casos, o uso da MFEL, a não ser que o elemento estrutural possua grandes dimensões, como ocorre em barragens e pilares de pontes.

Um exemplo de como o MFEL é inadequada a estruturas de concreto com pequenas dimensões foi dado por Shah (1999). Ele analisou um gráfico $G_{F}$ (calculado usando MFEL) versus resistência à compressão do concreto, e percebeu um acréscimo no valor da tenacidade ao fraturamento, que não condiz com a realidade. Quanto maior a resistência do concreto, mais frágil é seu comportamento, sendo assim, o fator $G_{F}$ deveria diminuir ao invés de aumentar.

\subsubsection{Mecânica do Fraturamento Não Linear (MFNL)}

Quando a zona de processos inelásticos possuir dimensões consideráveis em relação às dimensões do corpo analisado, o método deverá ser o MFNL.

Para materiais com comportamento quase-frágil, como o concreto, diversos modelos de cálculo são propostos. Segundo Bittencourt (1999), pode-se dizer que estes modelos 
baseiam-se no conceito do modelo coesivo (ou modelo da fissura fictícia coesiva) ou no modelo elástico equivalente (ou elástico efetivo).

Para escolher o método mais adequado, Bittencourt (1999) explica que a taxa de liberação de energia necessária para avançar uma fissura em material quase-frágil é dada por:

$$
G_{q}=G_{I C}+G_{F}
$$

onde o índice $q$ indica o material de comportamento quase-frágil, $G_{I C}$ é a energia consumida para gerar duas superfícies livres e $G_{F}$ é a energia para vencer os efeitos de ponte dos agregados (efeito coesivo).

Quando a primeira parcela da equação pode ser desprezada, admite-se que os efeitos coesivos são predominantes e utiliza-se o modelo da fissura fictícia coesiva. Do contrário, quando a segunda parcela for desprezível, utiliza-se o modelo elástico equivalente.

Miller (2008) explica que no modelo elástico equivalente, a modelagem da zona do processo de fraturamento é feita considerando o mecanismo de dissipação de energia proposto por Griffith-Irwin, assumindo $\sigma(w)=0$, que corresponde ao modelo de uma fissura elástica sujeita à tração livre.

Já, o modelo da fissura fictícia foi proposto por Hillerborg e suas características estão apresentadas na Figura 2.3.

É possível visualizar três regiões distintas: uma onde a fissura já ocorreu e suas faces estão totalmente separadas sem transmissão de esforços, outra onde os agregados fazem o travamento da propagação da abertura e por último, a região chamada de zona de processo, onde podem ser observadas pequenas fissuras difusas. 


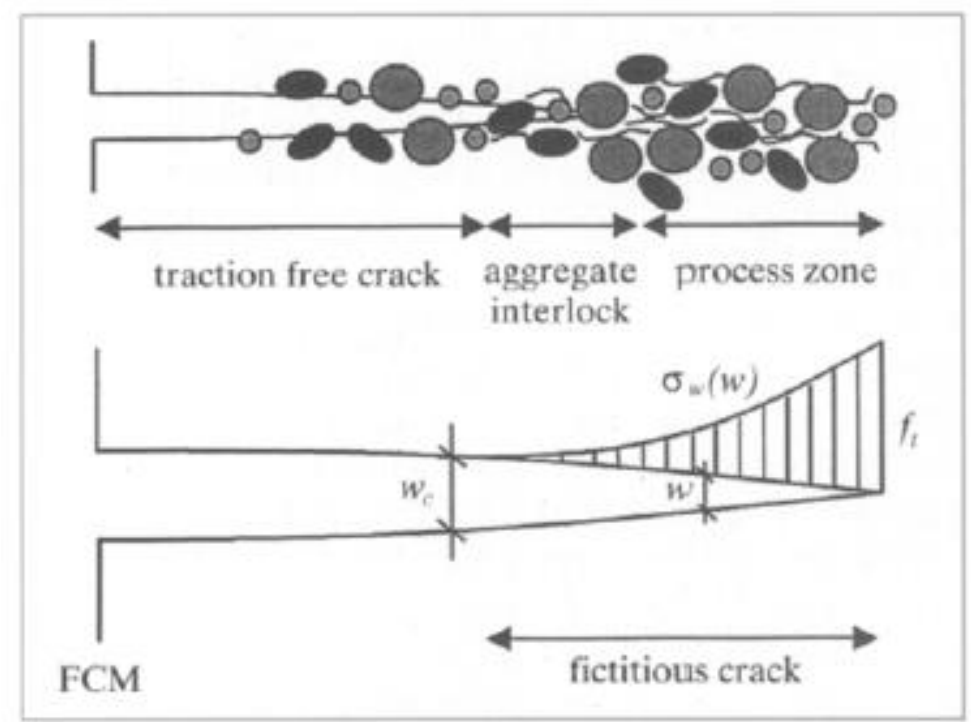

Figura 2.3 - Características do modelo da fissura fictícia RILEM TC 162-TDF (2002, p. 264)

Equacionando o sistema, tem-se no início da fissura:

$$
\sigma_{w}(0)=f_{t}
$$

onde $f_{t}$ é a resistência do concreto à tração.

E no final da abertura:

$$
\sigma_{w}\left(w_{c}\right)=0
$$

Admitindo que não haja perda de energia no processo de abertura da fissura, a relação tensão $x$ abertura da fissura pode ser representada pela energia de fraturamento $G_{F}$ definida em termos da área abaixo da curva:

$$
G_{F}=\int_{0}^{w} \sigma(w) \cdot d w
$$

O modelo da fissura fictícia foi incorporado à RILEM TC 162-TDF (2002) e os resultados são obtidos através da relação tensão x abertura da fissura. Essa norma pode ser 
aplicada para concretos comuns e compósitos cimentícios reforçados com fibras de aço, desde que os materiais apresentem um comportamento conhecido por "softening", que pode ser traduzido como amolecimento ou abrandamento. Proença e Pituba (2000) explicam que esse fenômeno pode ser observado em ensaio de compressão uniaxial de concreto simples com deformação controlada, onde nota-se que a partir da carga máxima, a relação tensão $x$ deformação do concreto mostra um gradual decréscimo de resistência com o aumento da deformação axial. Quando o concreto é reforçado com fibras, esse fenômeno diz respeito à ruptura ou arrancamento delas conforme ocorre abertura da fissura, sem aumento da capacidade de carga do corpo de prova após a formação da primeira fissura (Figura 2.4).

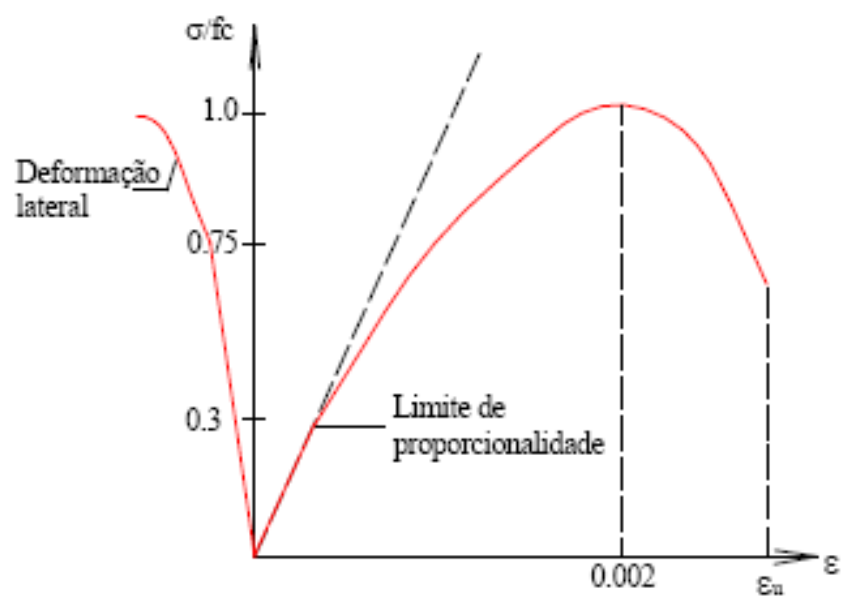

Figura 2.4 - Representação do comportamento "softening" do concreto (PROENÇA; PITUBA, 2000, p. 5)

\subsubsection{Rilem}

Conforme comentado anteriormente, a RILEM TC 162-TDF (2002) utiliza o método da fissura fictícia e estuda o comportamento do concreto reforçado com fibras de aço (CRFA). Embora semelhantes em muitos aspectos, a norma ressalta que a abordagem do modelo da fissura fictícia para a iniciação, propagação e abertura de fissuras em CRFA difere-se significativamente daquela utilizada em concretos convencionais. As fibras funcionam como pontes unindo as duas faces da fissura, dificultando sua abertura. Dessa maneira, a abertura da fissura $\left(w_{c}\right)$ deixa de ser um parâmetro relevante na análise e faz com que $G_{F}$ também perca importância do ponto de vista prático. Por isso, a norma propõe que sejam encontrados 
valores da função $\sigma(w)$ correspondentes a faixa de fissuras aceitáveis, como o intervalo entre 0 e $1,5 \mathrm{~mm}$.

Ao regulamentar os procedimentos de ensaio e os métodos para cálculo de alguns parâmetros, a RILEM TC 162-TDF (2002) fixa valores para abertura da fissura que corresponderão a tensões representativas do concreto reforçado com fibra de aço. Mais detalhes sobre o ensaio e seus resultados são vistos no Capítulo 3.

\subsubsection{Modos de fraturamento}

São três as maneiras como as fissuras podem propagar-se em um sólido, dependendo do tipo de solicitação a qual está sendo submetido. A Tabela 2.1 mostra quais são elas e suas características:

Tabela 2.1 - Modos de propagação das fissuras

\begin{tabular}{c|c|c}
\hline Modo de abertura & $\begin{array}{c}\text { A fissura propaga-se no } \\
\text { plano normal ao seu } \\
\text { comprimento. }\end{array}$ \\
(“opening mode") & $\begin{array}{c}\text { Modo cisalhante } \\
\text { ("shear mode") }\end{array}$ & $\begin{array}{c}\text { Propagação da fissura } \\
\text { provocada pelo } \\
\text { porregamento entre as } \\
\text { faces na direção do } \\
\text { comprimento da fissura. }\end{array}$ \\
\hline
\end{tabular}


O Modo I é o responsável pela maioria das fissuras, uma vez que os outros dois modos dificilmente ocorrem isoladamente.

\subsection{Concreto com fibras}

Sem dúvida, o concreto é um dos materiais mais importantes da construção civil mundial. Isso não impede dizer que ele possua uma série de limitações, como por exemplo, a baixa resistência à tração quando comparada à sua resistência à compressão, e a baixa capacidade de deformação, que resulta em baixa resistência à iniciação e propagação de fissuras. Para minimizar esses problemas, pesquisas mostram que a inserção de fibras tem se apresentado como uma solução eficaz.

Ao inserir fibras no concreto, cria-se um compósito, ou seja, um material formado por dois ou mais materiais diferentes. Os materiais que compõem um compósito são classificados em matriz e reforço. Embora o concreto por si só já seja um compósito (com poros, agregados e pasta) ao inserir fibras, as fases tornam-se o concreto (matriz) e as fibras (reforço).

As fibras são materiais descontínuos e esbeltos, cujo comprimento é bem maior que as dimensões de sua seção transversal. Elas são adicionadas ao concreto com o intuito de melhorar as características da matriz cimentícia no período pós-fissuração, funcionando como pontes de transmissão de tensões entre as duas faces da abertura. Isso permite minimizar a tensão concentrada na ponta da fissura e retardar sua propagação (Figura 2.5). Com consequência, o concreto que possui comportamento frágil, passa a ter um comportamento pseudo-frágil ou não frágil (FIGUEIREDO, 2005, BENTUR; MINDESS, 1990). Em outras palavras, o concreto continua apresentando uma resistência residual aos esforços aplicados, mesmo após a fissuração, o que corresponde ao aumento de tenacidade do material. Além disso, Uygunoglu (2008) complementa, dizendo que a adição de fibras na mistura do concreto, melhora significativamente propriedades como tração, flexão, impacto, fadiga, resistência à abrasão e capacidade de deformação. 


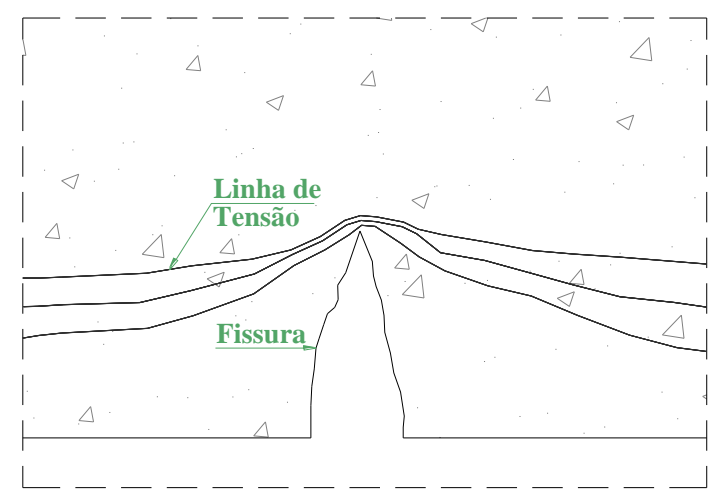

a) Concreto sem fibras

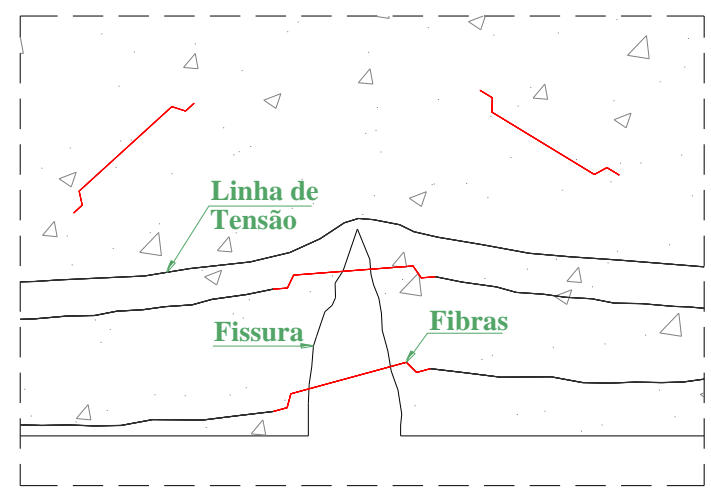

b) Concreto com fibras

Figura 2.5 - Processo de transmissão de tensão entre as faces da fissura

Uma característica peculiar das fibras é que elas ficam espalhadas no concreto de maneira aleatória e em três dimensões, interessante quando o assunto é o combate à retração. Em contrapartida, em situações específicas, com esforços definidos em um plano, como flexão, por exemplo, o dimensionamento estrutural utilizando barras de aço convencional, é a maneira mais econômica de solucionar o problema. Porém, quando o assunto é reforço estrutural, às vezes, o custo x benefício permite utilizar fibras em determinadas aplicações.

A origem das fibras pode ser vegetal, como as de sisal e coco, ou sintética, como as de nylon e polipropileno. A primeira apresenta problema relativo à durabilidade quando aplicada em matriz de base cimentícia devido à alcalinidade encontrada. Já a segunda, está ganhando espaço no mercado, sobretudo por substituir as fibras de amianto, que comprovadamente apresentam perigo à saúde. Por apresentar baixo módulo de elasticidade, sua aplicação só é interessante em matrizes onde o reforço não é o objetivo principal, como será explicado. Um exemplo seria o caso ocorrido no Eurotúnel, onde a pressão interna provocada por um incêndio causou o comprometimento do revestimento. Esse fato não teria acontecido se tivessem utilizado as fibras de polipropileno, que com a alta temperatura teriam se fundido e aberto espaço para a saída do vapor.

Independente da origem, a vantagem é "um ganho de desempenho no que se refere a esforços como impacto e redução da fissuração do material”, explica Figueiredo (2000).

O gráfico da Figura 2.6, retirado de Figueiredo (2000), explica de forma clara como funciona o reforço da matriz através da utilização de fibras: 


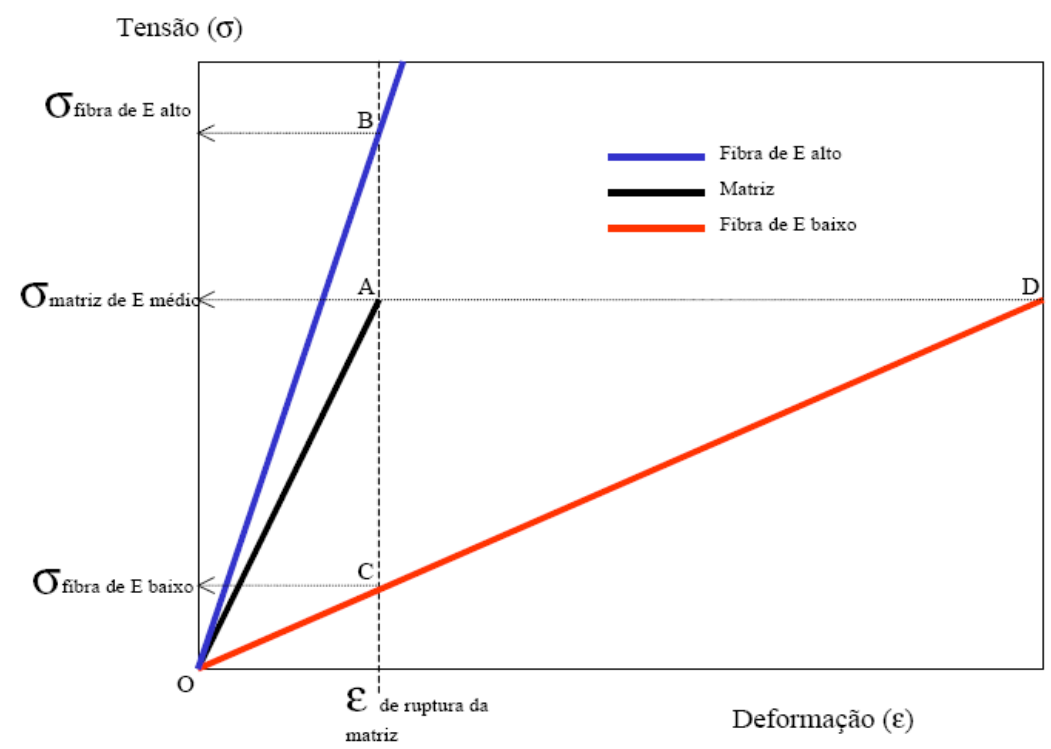

Figura 2.6 - Diagrama de tensão por deformação elástica de matriz e fibras de alto e baixo módulo de elasticidade trabalhando em conjunto (FIGUEIREDO, 2000, p. 5)

Suponhamos dois corpos de prova: o primeiro confeccionado com uma matriz hipotética reforçada com fibras de baixo módulo de elasticidade, e o segundo com a mesma matriz, porém reforçada com fibras de alto módulo de elasticidade. Ambas as fibras apresentam comportamento elástico perfeito.

Nos dois casos, ao aplicar o carregamento, a matriz se deforma até sua fissuração, o que coincide com a reta OA do gráfico. Nesse ponto, as fibras começam a ser solicitadas. No primeiro caso, com as fibras de baixo módulo, no ponto de deformação máxima da matriz, a tensão da fibra está muito baixa (ponto C), sendo necessária uma grande deformação para que a fibra atinja a mesma tensão que a matriz possuía (ponto D). O que geralmente ocorre, é que fibras com baixo módulo apresentam baixa resistência também, impossibilitando a tensão de atingir valor igual ao da matriz. Resumidamente, elas não são interessantes como reforço, com isso, seu uso em concretos onde se utiliza cimentos de alta resistência inicial, aceleradores de pega e redutores de água para atingir resistências em curto espaço de tempo, passa a ser inconveniente.

Já no segundo caso, quando a matriz atinge seu limite, a fibra está mais tensionada, suportando um aumento de carga com pouca deformação. Obviamente, desde que tenha resistência mecânica para tal aumento. Isso faz com que as fibras de alto módulo funcionem como reforço. 
Como exemplo de fibras de alto módulo, pode-se citar as de aço. Devido às suas propriedades, elas atuam como reforço do concreto endurecido, podendo, inclusive, substituir a armadura convencional em determinadas aplicações. As fibras de aço são o tema da seção (2.3).

De maneira informativa, a Tabela 2.2 mostra as propriedades de diferentes tipos de fibras:

Tabela 2.2 - Valores de resistência e módulo de elasticidade para diversos tipos de fibras e matrizes

\begin{tabular}{c|c|c|c|c|c}
\hline Material & $\begin{array}{c}\text { Diâmetro } \\
(\mu \mathrm{m})\end{array}$ & $\begin{array}{c}\text { Densidade } \\
\left(\mathrm{g} / \mathrm{cm}^{3}\right)\end{array}$ & $\begin{array}{c}\text { Módulo de } \\
\text { elasticidade } \\
(\mathrm{GPa})\end{array}$ & $\begin{array}{c}\text { Resistência } \\
\text { à tração } \\
(\mathrm{MPa})\end{array}$ & $\begin{array}{c}\text { Deformação } \\
\text { na ruptura } \\
(\%)\end{array}$ \\
\hline Aço & $5-500$ & 7,84 & $190-210$ & $0,5-2,0$ & $0,5-3,5$ \\
\hline Vidro & $9-15$ & 2,60 & $70-80$ & $2-4$ & $2-3,5$ \\
\hline Amianto & $0,02-0,4$ & 2,6 & $160-200$ & $3-3,5$ & $2-3$ \\
\hline Polipropileno & $20-200$ & 0,9 & $5-7,7$ & $0,5-0,75$ & 8,0 \\
\hline Kevlar & 10 & 1,45 & $65-133$ & 3,6 & $2,1-4,0$ \\
\hline Carbono & 9 & 1,9 & 230 & 2,6 & 1,0 \\
\hline Nylon & - & 1,1 & 4,0 & 0,9 & $13-15$ \\
\hline Celulose & - & 1,2 & 10 & $0,3-0,5$ & - \\
\hline Acrílico & 18 & 1,18 & $14-19,5$ & $0,4-1,0$ & 3,0 \\
\hline Polietileno & - & 0,95 & 0,3 & $0,7 \times 10^{-3}$ & 10 \\
\hline $\begin{array}{c}\text { Fibra de } \\
\text { Madeira }\end{array}$ & - & 1,5 & 71 & 0,9 & - \\
\hline Sisal & $10-50$ & $1-50$ & - & 0,8 & 3,0 \\
\hline $\begin{array}{c}\text { Matriz de } \\
\text { cimento (para } \\
\text { comparação) }\end{array}$ & - & 2,50 & $10-45$ & $3,7 \times 10^{-3}$ & 0,02 \\
\hline
\end{tabular}

Além do tipo de fibra, a quantidade volumétrica inserida no concreto, é preponderante para obter o resultado esperado do compósito. Mehta e Monteiro (2008) classificam os compósitos com relação ao volume de fibra da seguinte maneira:

- Baixa fração volumétrica $(<1 \%)$ : as fibras são utilizadas para reduzir a fissuração por retração; 
- Fração volumétrica moderada (entre 1 e $2 \%$ ): nessa faixa, as fibras aumentam o módulo de ruptura, a tenacidade à fratura e a resistência ao impacto;

- Alta fração volumétrica (>2\%): as fibras levam o concreto ao endurecimento por deformação dos compósitos.

\subsubsection{Geometria das fibras}

Uma maneira de avaliar a influência da geometria das fibras no concreto é utilizando o parâmetro conhecido como fator de forma. Esse fator consiste na divisão do comprimento da fibra pelo diâmetro do círculo cuja área é equivalente à da seção transversal da fibra. Figueiredo (2005) explica que em geral, quanto maior o fator de forma, maior é a capacidade resistente do concreto pós-fissurado. Porém, caso o comprimento da fibra seja muito grande, ou a resistência da matriz seja muito elevada, haverá um aumento na aderência entre concreto e fibra, que impedirá o seu deslizamento, possibilitando a abertura da fissura. O mecanismo é interrompido quando houver o rompimento da fibra, agregando pouco ou nenhuma resistência ao sistema. Por outro lado, se o fator de forma for muito pequeno, as fibras escorregarão sob baixos carregamentos, não contribuindo muito para diminuir a fissuração.

Para Figueiredo (2005), deve haver uma compatibilidade dimensional entre o agregado graúdo e as fibras, sendo que estas devem ser igual ou superior ao dobro da dimensão máxima do agregado utilizado. Esta compatibilidade permite que as fibras sejam ancoradas corretamente e o reforço seja mesmo do concreto e não meramente da argamassa, já que as fissuras propagam-se preferencialmente na interface entre argamassa e agregado (Figura 2.7). 


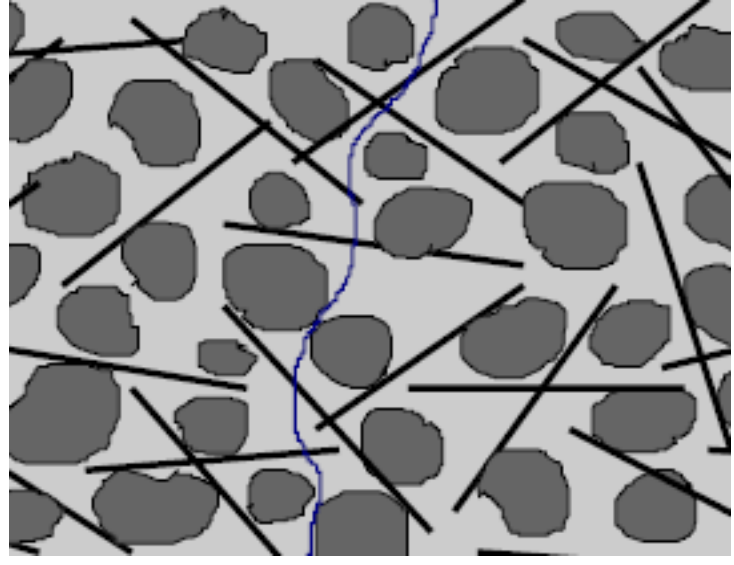

a) Concreto reforçado com fibras onde há compatibilidade dimensional entre estas e o agregado graúdo

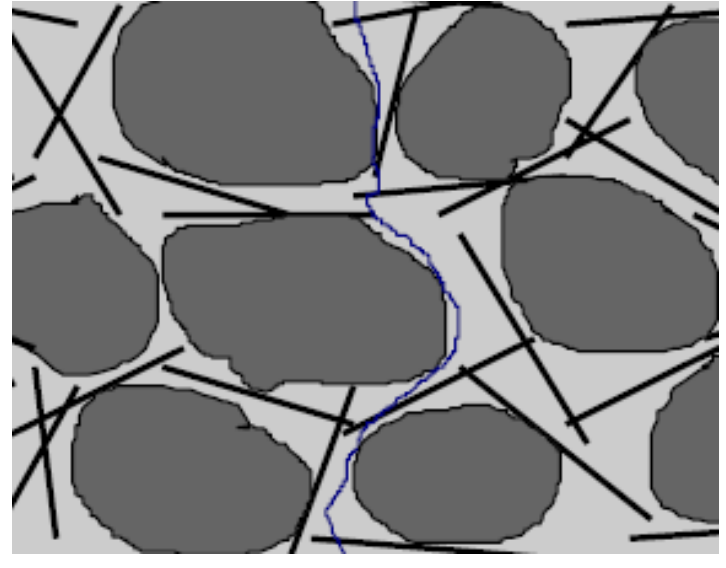

b) Concreto reforçado com fibras onde não há compatibilidade dimensional entre estas e o agregado graúdo

Figura 2.7 - Compatibilidade entre fibras e agregados graúdos (Adaptado de FIGUEIREDO, 2000, p. 19)

Cuidados devem ser tomados na produção do concreto reforçado com fibras para que não apareçam os chamados ouriços ou nichos, que nada mais são que o "empelotamento" das fibras. Quanto maior o fator de forma, mais susceptível de acontecer o fenômeno.

\subsubsection{Tenacidade}

Como explicado na Seção 2.1.1, tenacidade é uma habilidade do material em absorver energia antes e durante o processo de fissuração. Uma maneira de obter essa propriedade é calculando a área sob a curva tensão $x$ deformação. A Figura 2.8 representa as curvas típicas de concreto convencional e concreto reforçado com fibras.

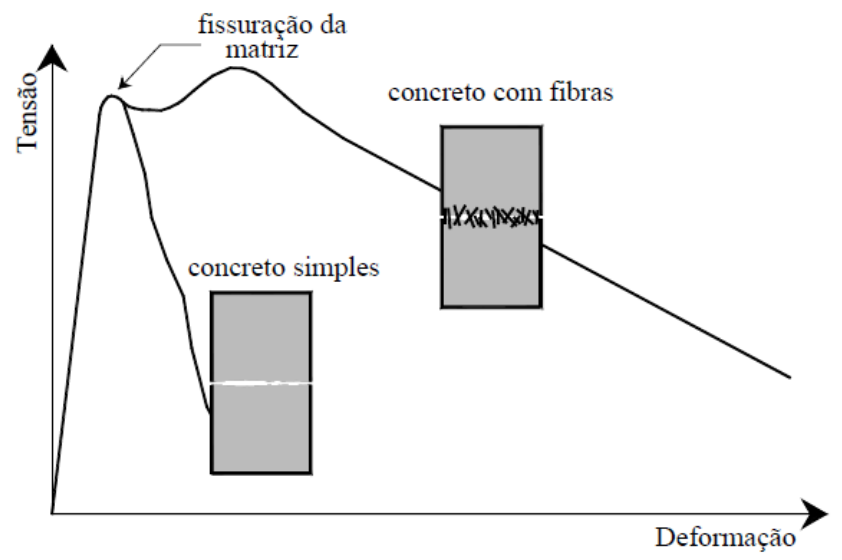

Figura 2.8 - Comportamento de matrizes cimentícias (FERRARI, 2007, p.21) 
Ao atingir a resistência última à flexão, o concreto convencional rompe. Enquanto isso, o concreto com fibras continua se deformando e suportando carga. A abertura da fissura é retardada até que haja rompimento ou deslizamento da fibra que intercepta a fissura.

\subsubsection{Trabalhabilidade}

Mehta e Monteiro (2008) explicam que a diminuição da trabalhabilidade do concreto é um fato quando se acrescentam fibras. Independentemente do tipo, a trabalhabilidade do concreto é influenciada pelo volume de fibras inseridas e pelo maior fator de forma. Isso acontece porque ao adicionar as fibras, adiciona-se também área superficial que demanda água de molhagem, resultando um concreto muito mais coeso. (FIGUEIREDO, 2005). Por isso, uso de artifícios como aumento da relação água/cimento e uso de superplastificante, pode proporcionar melhorias na trabalhabilidade do compósito.

Com um material mais denso, o Slump Test deixa de ser um ensaio recomendado para analisar a trabalhabilidade, passando a ser mais apropriado o ensaio Vebe. O ACI 544.2R-89 alerta para o inconveniente do tamanho e peso do equipamento utilizado, o que pode inviabilizar a realização do ensaio em obra.

\subsection{Concreto com fibras de aço}

Dentre as fibras disponíveis no mercado, a de aço é a mais utilizada em estruturas de concreto. Características como facilidade de obtenção, economia, resistência à agressividade ambiental e compatibilidade com a matriz cimentícia, fazem dela uma boa opção para pisos industriais, túneis, elementos pré-moldados e estabilização de taludes.

Para a ABNT NBR 15530 (2007, p. 1), fibras de aço são "fillamentos de aço descontínuos produzidos especificamente para o uso em concretos". A norma brasileira divide as fibras em classes e tipos, e regulamenta o fator de forma mínimo e o limite de resistência à tração do aço (Tabela 2.3). 
Capítulo 2 - Revisão Bibliográfica

Tabela 2.3 - Tipos e classes das fibras de aço produzidas especificamente para uso em concreto (Adaptado da ABNT NBR 15530: 2007, p. 3)

\begin{tabular}{|c|c|c|c|}
\hline $\begin{array}{c}\text { Tipo } \\
\text { (geometria) }\end{array}$ & Classe da fibra & $\begin{array}{l}\text { Fator de forma } \\
\text { mínimo } \\
(\lambda)\end{array}$ & $\begin{array}{c}\text { Limite de resistência à } \\
\text { tração do aço } \\
\mathrm{fu}(\mathrm{MPa})^{*}\end{array}$ \\
\hline \multirow{2}{*}{$\begin{array}{c}\text { A } \\
\text { (com ancoragem } \\
\text { nas extremidades) }\end{array}$} & $\mathrm{I}$ & 40 & 1000 \\
\hline & II & 30 & 500 \\
\hline \multirow{3}{*}{$\begin{array}{c}\text { C } \\
\text { (corrugada) }\end{array}$} & $\mathrm{I}$ & 40 & 800 \\
\hline & II & 30 & 500 \\
\hline & III & 30 & 800 \\
\hline \multirow{2}{*}{$\begin{array}{c}\mathrm{R} \\
\text { (reta, sem } \\
\text { ancoragem nas } \\
\text { extremidades) }\end{array}$} & $\mathrm{I}$ & 40 & 1000 \\
\hline & II & 30 & 500 \\
\hline \multirow[t]{3}{*}{ Classes: } & \multicolumn{3}{|c|}{$\mathrm{I}=$ fibra oriunda de arame trefilado a frio } \\
\hline & \multicolumn{3}{|c|}{$\mathrm{II}=$ fibra oriunda de chapa laminada cortada a frio } \\
\hline & \multicolumn{3}{|c|}{ III = fibra oriunda de arame trefilado e escarificado } \\
\hline
\end{tabular}

* Esta determinação deve ser feita no aço, no diâmetro equivalente final imediatamente antes do corte

Embora o objetivo da adição das fibras não seja o aumento da resistência à compressão e sim, o aumento da tenacidade, estudos atuais não entram em consenso sobre o assunto. Enquanto por um lado, a resistência à compressão pode diminuir devido à má compactação do concreto, por outro, as fibras dificultam a abertura de fissuras que se iniciam devido aos esforços de tração e cisalhamento presentes nos ensaios de compressão. A RILEM TC 162-TDF (2003) recomenda que os ensaios à compressão sejam realizados normalmente, como se faz com concreto simples, em corpos de prova cilíndricos de 15 x $30 \mathrm{~cm}$.

Ao dosar um concreto com fibras de aço, deve estar clara a finalidade de sua utilização, designando-as como reforço ou não. Para isso, existe uma definição conceitual de volume crítico de fibras. Quando o volume de fibras inseridas é igual ao crítico, o concreto mantém sua capacidade portante mesmo após a fissuração da matriz. No caso do volume ser inferior ao crítico, a carga diminui após a fissuração da matriz, e no caso do volume ser superior ao crítico, há aumento na capacidade de suporte de carga. Para Figueiredo (2000), o volume crítico das fibras de aço gira em torno de $1 \%$ do volume de concreto. 
Além da responsabilidade estrutural, o volume de fibras de aço também rege o preço do $\mathrm{m}^{3}$ do concreto. Obviamente que as vantagens das fibras devem ser levadas em conta, mas mesmo com taxas relativamente baixas, o valor do concreto pode dobrar.

É fácil imaginar, que quanto mais fibras presentes na seção transversal do elemento estrutural, melhor será a distribuição de tensões entre as fibras e maior será a tenacidade proporcionada ao concreto. Como a taxa de fibras é medida em porcentagem ou em massa por metro cúbico de concreto, quanto menor o fator de forma, maior o número de fibras presente na seção, sendo, portanto, mais interessante economicamente.

Com relação ao comprimento das fibras de aço, a recomendação continua sendo igual ou superior ao dobro do diâmetro do agregado, acrescentando que o comprimento máximo deve ser 1/3 da menor dimensão do elemento estrutural a ser concretado (ACI 544.2R-89). Além disso, o comprimento deve ser compatível com a resistência proporcionada pela matriz cimentícia. Assim como comentado na Seção 2.1.1, concreto com resistência baixa ou moderada deve ter fibras com comprimento suficiente para atingir a tensão de ruptura do aço e não permitir o arrancamento delas durante a abertura da fissura. Por outro lado, concreto com resistência mais elevada, e consequentemente, melhor aderência entre fibra e matriz, deve ter comprimento que permita o deslizamento sem rompimento das fibras. Para Aïtcin (2000), o aumento da tenacidade em concreto de alto desempenho pode ser adquirido de duas maneiras: mantendo o mesmo fator de forma e geometria das fibras, aumentando a tensão de ruptura do aço, ou desenvolvendo fibras mais curtas, com menor diâmetro para reduzir a tensão de aderência a nível inferior à tensão de ruptura do aço. Para o autor, a segunda opção é a mais promissora, propiciando mais fibras por unidade de volume. A dificuldade é encontrar fibras pequenas no mercado.

Para dosar um concreto com fibras de aço, algumas medidas devem ser tomadas para garantir a trabalhabilidade, além daquelas já descritas anteriormente. Como em geral as fibras são inseridas em matrizes cimentícias convencionais, Figueiredo (2000), recomenda que o teor de argamassa do concreto deve ser de no mínimo 50\%, a relação água/cimento $(a / c)$ deva ser no máximo de 0,55 e a relação água materiais secos $(H)$, de no máximo $11,5 \%$. Oliveira, Ramos e Gomes (2005) estudaram a inserção de fibras em concreto autoadensável e observaram qualitativamente que quando se emprega um teor de argamassa adequado, mesmo para volumes mais elevados de fibras, estas se distribuem homogeneamente sem sofrer segregação. Para eles, o volume de fibras de aço inserido no concreto pode ser pensado como um aumento na fração de agregado graúdo, sendo necessário compensá-lo com aumento na 
fração de agregado miúdo. Por isso propuseram uma equação que relaciona a argamassa seca com o concreto seco (Equação 2.5):

$$
A_{s}(\%)=\frac{1+f+a}{1+f+m} \cdot 100
$$

onde: 1 é a proporção unitária, em massa, de cimento; $f$ é a proporção em massa de filler ou material fino; $a$ é a proporção em massa de areia e $m$ é o total de agregados (miúdos + graúdos).

Através de análises experimentais, os autores concluíram que o teor de argamassa ótimo varia entre $60 \%$ e $75 \%$, dependendo do volume e do fator de forma das fibras utilizadas.

As propriedades incorporadas ao concreto com a adição de fibras de aço, como a tenacidade e a resistência residual, podem ser medidas a partir de ensaios de tração na flexão de corpos de prova prismáticos, preferencialmente realizados em três pontos. Neste trabalho, optou-se por utilizar o método proposto pela RILEM TC 162-TDF (2002), por ser de fácil realização, obter resultados satisfatórios e pela importância a nível mundial que a entidade está adquirindo. No entanto, não se pode deixar de citar a consagrada norma americana (ASTM C 78, ASTM C 293 e ASTM C 1018) e japonesa (JCI SF4).

A RILEM TC 162-TDF (2003) classifica o concreto reforçado com fibras de aço usando dois parâmetros, $\mathrm{FL}_{0,5}$ e $\mathrm{FL}_{3,5}$, que são determinados pelas forças de flexão residual $f_{R, 1}$ e $f_{R, 4}$, respectivamente. As forças são calculadas através da Equação 2.6 em pontos específicos de deformação $\left(\delta_{\mathrm{R}, \mathrm{i}}\right)$ ou de abertura da fissura $\left(\mathrm{CMOD}_{\mathrm{i}}\right)$ :

$$
\begin{gathered}
f_{R, i}=\frac{3 \cdot F_{R, i} \cdot L}{2 \cdot b \cdot h_{s p}^{2}} \\
\mathrm{CMOD}_{1}=0,5 \mathrm{~mm}-\delta_{\mathrm{R}, 1}=0,46 \mathrm{~mm} \\
\mathrm{CMOD}_{4}=3,5 \mathrm{~mm}-\delta_{\mathrm{R}, 4}=3,00 \mathrm{~mm}
\end{gathered}
$$

onde:

$f_{r i}=$ tensão de flexão residual no ponto $i\left(\mathrm{~N} / \mathrm{mm}^{2}\right)$; 
$F_{R i}=$ carga registrada no ponto de $\mathrm{CMOD}_{\mathrm{i}}$ ou $\delta_{\mathrm{R}, \mathrm{i}}(\mathrm{N})$

$L=$ comprimento do corpo de prova $(\mathrm{mm})$;

$b=$ largura do corpo de prova $(\mathrm{mm})$;

$h_{s p}=$ distância entre a ponta da fissura e a face superior do corpo de prova (mm).

Os valores de $\mathrm{FL}_{0,5}$ e $\mathrm{FL}_{3,5}$ devem ser reduzidos em múltiplos de 0,5 MPa e devem variar entre 1 e $6 \mathrm{MPa}$ e 0 e $4 \mathrm{MPa}$, respectivamente. Com isso, a classe de resistência residual é representada por $\mathrm{FL} \mathrm{FL}_{0,5} / \mathrm{FL}_{3,5}$ com seus correspondentes valores, Assim, citando o exemplo da norma, um concreto com resistência à compressão de $30 \mathrm{MPa}$ e $\mathrm{f}_{\mathrm{R}, 1}=2,2 \mathrm{MPa} \mathrm{e}$ $\mathrm{f}_{\mathrm{R}, 4}=1,5 \mathrm{MPa}$ teria $\mathrm{FL}_{0.5}=2,0 \mathrm{MPa}$ e $\mathrm{FL}_{3.5}=1,5 \mathrm{MPa}$ e pode ser classificado como C30/37 FL 2.0/1.5.

O ensaio e demais detalhes sobre a RILEM TC 162-TDF (2003) serão relatados no Capítulo 3.

\subsubsection{Durabilidade}

Embora recorrentes, as dúvidas sobre durabilidade dos compósitos reforçados com fibras de aço muitas vezes não são necessárias. Primeiro porque as fibras mais internas na peça estrutural estão protegidas pela pasta de cimento da mesma maneira como as barras convencionais de aço. Segundo que as mais externas, por apresentarem dimensões pequenas, não proporcionam diferença potencial (originadas por umidade e tensões no aço ou concreto, por exemplo) suficiente para produzir corrosão. Entretanto, mesmo que ocorra, não será suficiente para destacar o concreto adjacente. Contra essa vertente, tem-se ainda, o benefício das fibras impedirem a abertura das fissuras, protegendo o concreto e as barras convencionais de agentes externos, consequentemente aumentando a durabilidade da estrutura.

\subsection{Zona de Transição}

Embora o concreto seja um material bastante antigo e o mais consumido na construção civil, ele apresenta uma estrutura bastante heterogênea e complexa, que ainda hoje continua sendo objeto de pesquisa. A nível macroscópico observa-se um elemento bifásico, composto de agregados envoltos em uma matriz cimentícia, como mostra a Figura 2.9: 


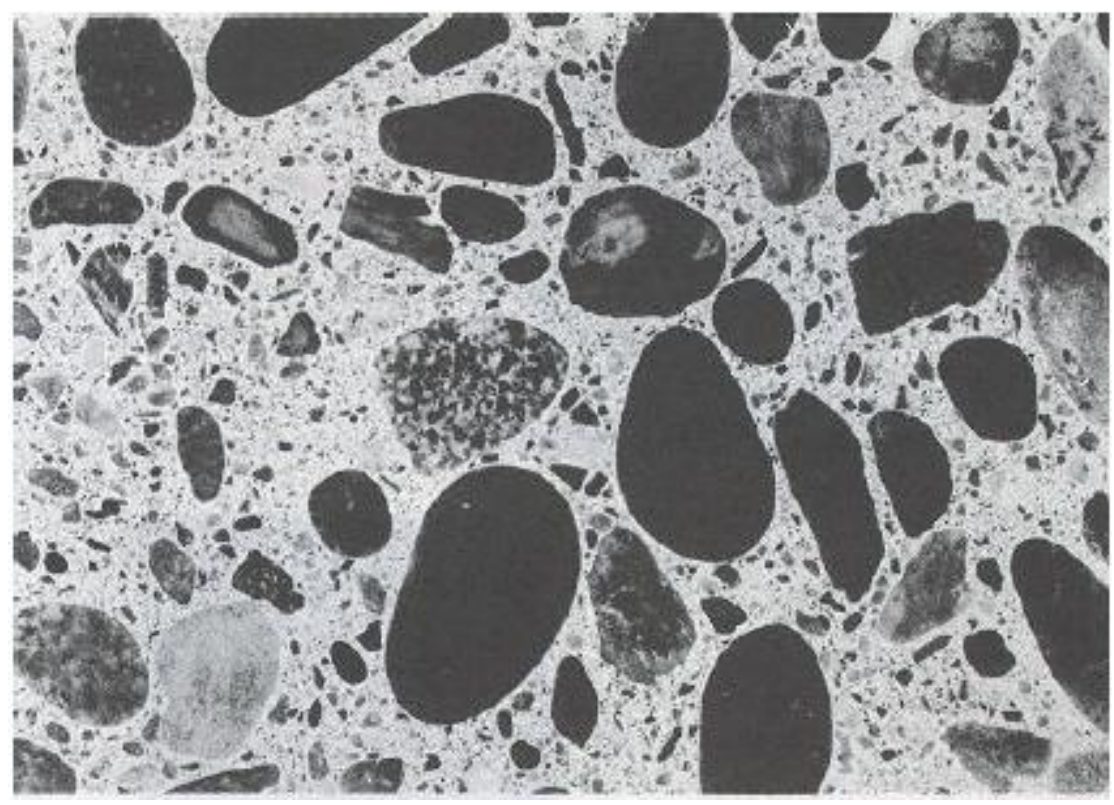

Figura 2.9- Visão macroscópica de um concreto polido (Adaptado de MEHTA; MONTEIRO, 1994, p.19)

Porém Mehta e Monteiro (1994) explicam que existe uma terceira fase, observada microscopicamente, que representa a região interfacial entre as partículas de agregado graúdo e pasta, chamada zona de transição. Ela é uma camada delgada, com espessura variando entre 10 e $50 \mu \mathrm{m}$, menos resistente que o restante da pasta de cimento e pode proporcionar diferenças significativas nas propriedades do concreto.

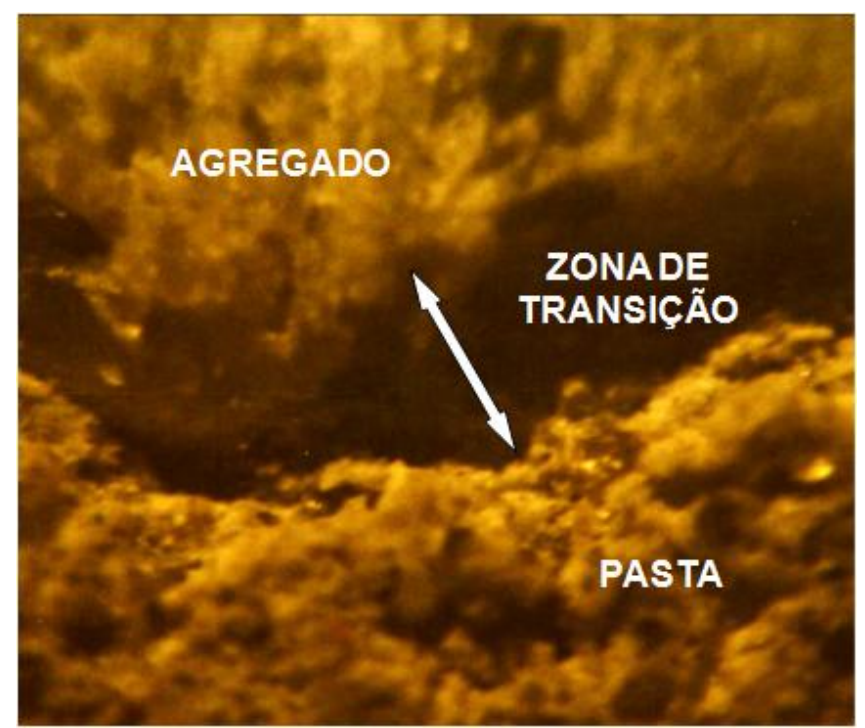

Figura 2.10- Visão microscópica do concreto (Adaptado de GRIGOLI; HELENE, 2001, p.11) 
O primeiro pesquisador a estudar a hidratação do cimento em contato com agregados minerais foi Farran em 1956. Seu objetivo principal, segundo Paulon (2005), era "fixar a influência da natureza mineralógica dos constituintes hidratados dos cimentos e dos materiais englobados, sobre as ligações que se estabelecem entre eles ao longo da pega e do endurecimento dos concretos". Para isso, ele relembrou a teoria de Le Chatelier, escrita em 1887 e até hoje adotada, que diz que a pasta plástica que circunda o agregado, tende a se cristalizar após o amassamento do concreto, formando assim, ligações do tipo sólido sobre sólido entre o aglomerante e o material englobado.

Farran imaginou então, duas formas de aderência entre os materiais: uma através da aderência mecânica ou aderência por rugosidade superficial, e outra através da aderência em escala de dimensões reticulares, uma espécie de ligação ideal, na qual os cristais de cimento dão continuidade ao agregado.

A partir disso, o pesquisador desenvolveu um método de observação dos defeitos de contato entre a pasta e os agregados, concluindo que havia interação entre esses materiais, e ainda, que essa interação ocorria de maneira diferente dependendo da origem do agregado. Em outras palavras, os agregados não são rigorosamente inertes. $\mathrm{O}$ que produz uma melhor aderência favorece a melhoria das propriedades mecânicas do concreto.

Paulon (2005) relata também que Bulk \& Dolch (1966) usaram a microscopia eletrônica de varredura para observar a formação de uma faixa fina e escura na superfície de agregados calcários em contato com a pasta de cimento. Essa faixa foi denominada auréola de transição (conhecida hoje, como zona de transição) e nela foram observados comportamentos bastante distintos em relação à pasta situada em região mais distante do agregado. Enquanto a pasta de cimento pode ser considerada como um meio isotrópico, a zona de transição é fortemente anisotrópica, ou seja, possui certa propriedade física que varia com a direção.

Essa interface é uma região de maior porosidade, além disso, há a formação de cristais de grandes dimensões, os quais apresentam, algumas vezes, uma orientação preferencial em relação à superfície do agregado, o que favorece a propagação de fissuras. Com isso, o concreto perde a característica de ser um material composto, pois sob carregamento, os agregados, que são menos deformáveis que a pasta de cimento, não contribuem para a resistência do conjunto, uma vez que a transferência de tensões entre a pasta de cimento e o agregado fica prejudicada. 


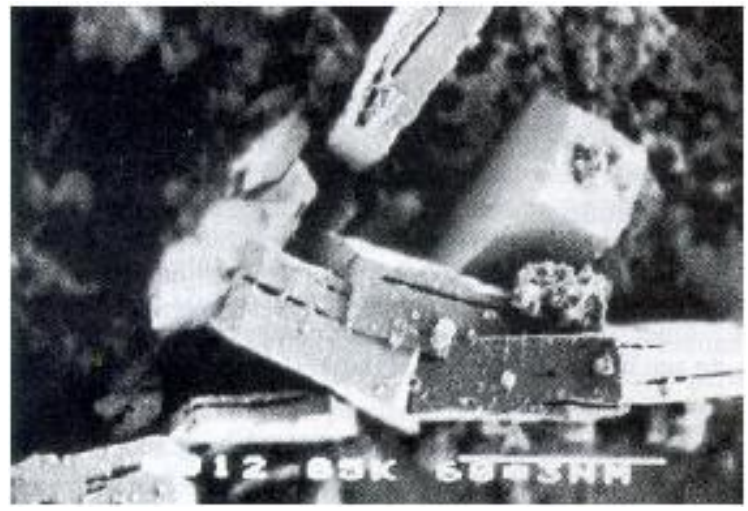

Figura 2.11- Micrografia eletrônica de varredura de cristais de hidróxido de cálcio na zona de transição (MEHTA; MONTEIRO, 1994, p.38)

Dessa maneira, aparecem as primeiras consequências irreversíveis que provocam o fechamento de poros quando o esforço for de compressão e fissuração quando o esforço for de tração ou cisalhamento. Sob carregamento, a tendência é o aumento dessas fissuras iniciais até que elas atinjam outra zona de transição e assim sucessivamente, geralmente percorrendo o contorno dos agregados.

Aïticin (2000) explica que as fissuras podem iniciar-se antes mesmo da atuação do carregamento com as tensões de tração provenientes das deformações de retração ou dilatação térmica e de secagem.

Paulon (2005) sintetiza o estudo da zona de transição dizendo que as suas características dependem de vários fatores, como o tipo de agregado, a relação água/aglomerante, o efeito de aditivos e adições, a natureza e a quantidade de componentes menores no material cimentício, entre outras. Além disso, quanto maiores forem as proporções de partículas chatas e alongadas dos agregados, maior será a tendência de acúmulo de água próxima às partículas, tornando mais fraca a pasta de cimento na região da interface, o que gera uma exsudação interna responsável pela microfissuração da pasta na região junto ao agregado.

Diante do exposto, seria óbvio pensar em reforçar essa região mais frágil, ou seja, a zona de transição. Para isso, uma opção é a utilização de materiais cimentícios como substituição de parte do cimento Portland. A sílica ativa, por exemplo, absorve água de amassamento suficiente para diminuir a fluidez da pasta próxima aos agregados e como consequência, diminui a espessura da zona de transição. Além disso, como veremos no item 2.4.1, ela é responsável por reagir com o hidróxido de cálcio, que é um cristal de baixa resistência do concreto, para formar o silicato de cálcio hidratado (CSH), que é o cristal 
responsável em conferir resistência à pasta. Isso estreita a auréola de transição a alguns micrômetros do agregado. Sem contar seu efeito filler onde, resumidamente, as pequenas partículas da sílica ocupam espaços vazios impedindo a comunicação entre os poros.

Utilizando ensaios de difratometria de raios $\mathrm{X}$ e estudando agregados e materiais pozolânicos brasileiros, Paulon (1995) concluiu que a sílica ativa demonstrou ser o material pozolânico mais eficiente em comparação com as cinzas volantes e a pozolana de argila calcinada, resultando na menor espessura da zona de transição em qualquer idade e agregado utilizado.

É importante lembrar que em concretos reforçados com fibras, sejam elas de qualquer origem, os perímetros das mesmas também funcionam como zona de transição. A diferença é que, dependendo o material da fibra, pode haver maior ou menor adesão à matriz.

\subsubsection{Sílica Ativa}

Segundo a ABNT NBR 13956-1997, sílica ativa ou microssílica é um "material decorrente do processo de produção de silício metálico ou ligas de ferro silício em fornos elétricos. Durante o processo é gerado o gás $\mathrm{SiO}$ que, ao sair do forno, oxida-se formando partículas de $\mathrm{SiO}_{2}$, sendo então captadas por sistemas de filtros coletores".

Antigamente esse pó fino era liberado para a atmosfera, mas com as fortes pressões das regulamentações ambientais dos governos dos países industrializados, os produtores tiveram que investir grandes recursos em sistemas de coletas daquela poeira, sem garantia alguma de retorno financeiro.

Embora a primeira utilização desse material tenha sido relatada em 1952 por um pesquisador norueguês, foi somente ao final dos anos 70 na Escandinávia que a sílica ativa começou a ser utilizada como material cimentício suplementar no concreto. As descobertas de pesquisadores dinamarqueses também ajudaram a popularizar o material, levando a uma rápida aceitação do material cimentício em quase todo o mundo em menos de cinco anos. Na América do Norte, ela só foi introduzida em meados dos anos 80. Então, o que era um problema para os fabricantes de silício e ferro silício passou a ser uma fonte rentável.

A microssílica pode apresentar uma cor que varia do cinza claro ao cinza escuro, dependente do teor de carbono existente. Suas partículas são esféricas, vítreas e extremamente pequenas. Seu diâmetro médio é da ordem de $0,1 \mu \mathrm{m}$, enquanto o cimento apresenta $10 \mu \mathrm{m}$. 
Outra comparação possível é em relação à sua área específica, que fica em torno de 20.000 $\mathrm{m}^{2} / \mathrm{kg}$, contra $300 \mathrm{~m}^{2} / \mathrm{kg}$ do cimento e $550 \mathrm{~m}^{2} / \mathrm{kg}$ da cinza volante, segundo o ACI 226 (1987). Além do tamanho extremamente reduzido, Aïtcin (2000) explica que o alto teor de sílica amorfa (não cristalina) das partículas, faz com que o material possua características peculiares que o tornam um material pozolânico muito reativo e bastante apropriado para adição em concretos e argamassas. As partículas se introduzem entre os grãos de cimento e se alojam nos vazios da pasta, proporcionando altíssima reatividade com os produtos decorrentes da hidratação do cimento. Além disso, reduzem o espaço disponível para a água e atuam como ponto de nucleação dos produtos de hidratação. Isso quer dizer que o crescimento dos cristais ocorrerá não somente a partir da superfície dos grãos de cimento, mas também nos poros ocupados pela microssílica e pela água. Como o espaço é bastante reduzido, ocorre a formação de um grande número de pequenos cristais ao invés de poucos cristais de grande tamanho, o que proporciona um refinamento da estrutura dos poros, gerando uma redução tanto da exsudação interna quanto superficial da mistura. E como tem origem metalúrgica, apresenta maior estabilidade em relação as suas propriedades físicas e químicas.

Como há uma redução na porosidade da pasta de cimento, consequentemente há uma maior impermeabilidade do concreto, que pode ser traduzida como o aumento da durabilidade da estrutura, melhorando o desempenho frente a agressões químicas, penetração de íons cloreto, reatividade álcali-agregado, resistência mecânica, abrasão, erosão, absorção, entre outras propriedades.

Em contrapartida aos efeitos benéficos da extrema finura da microssílica, o consumo de água necessário para o amassamento do concreto tende a aumentar com o aumento da taxa de sílica. Porém esse problema pode ser perfeitamente resolvido com a utilização de superplastificante. Alguns estudos (MEHTA, 1984; MEHTA, 1989) relatam que pequenas adições, em torno de 2 a $3 \%$ da massa de cimento, ao invés de aumentar o consumo de água, podem ser úteis no sentido de melhorar a estabilidade e trabalhabilidade do concreto. Segundo o autor, as microesferas, apesar de consumirem mais água para molhagem, atuam como rolamentos, facilitando o bombeamento e lançamento do concreto.

Ao ser adicionada ao concreto, a microssílica atua através de dois mecanismos: um físico e outro químico. A ação física ou efeito filler, caracteriza-se por importantes mudanças no comportamento reológico do concreto, transformando a microestrutura da zona de transição entre a pasta de cimento e os agregados e entre a pasta de cimento e as armaduras (barras ou fibras). Essas ligações se apresentam muito mais compactadas em comparação a 
um concreto sem adição, resultando em um material com desempenho superior. No estado endurecido, ajuda a eliminar os vazios, contribuindo para o fechamento granulométrico da pasta de cimento.

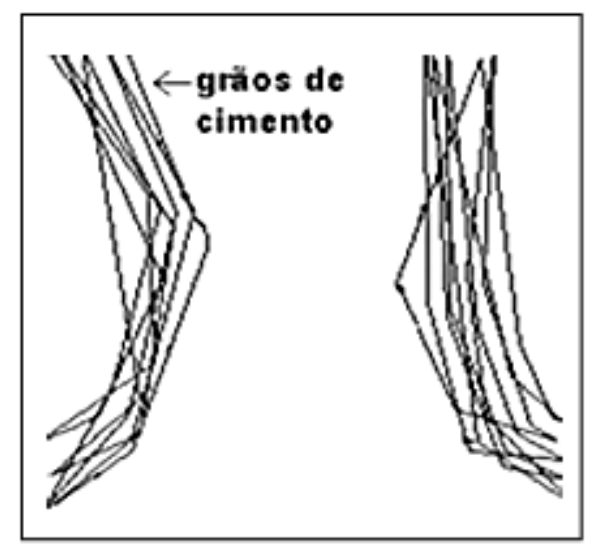

SEM SÍLICA ATIVA

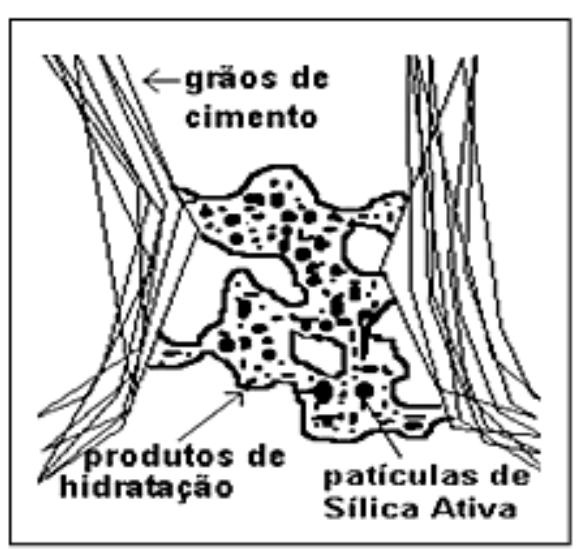

COM SÍLICA ATIVA

Figura 2.12 - Ação física ou efeito filler (TECNOSIL, 2008)

Já a ação química ou pozolânica, caracteriza-se pela reação de hidratação dos compostos do cimento Portland com a água, que produzem o silicato de cálcio hidratado (CSH) responsável pela resistência da pasta de cimento, e um sub-produto, o hidróxido de cálcio (15 a 25\% do volume da pasta), que é um cristal de baixa resistência, solúvel em água e que não contribui para a resistência ou durabilidade dos concretos. A sílica reage com o hidróxido de cálcio, transformando o cristal fraco em cristal resistente (CSH), o que proporciona grande aumento de resistência, impermeabilidade e durabilidade em concretos e argamassas. Segundo Dal Molin (1995), essas reações são rápidas e pouco variáveis o que possibilita períodos de cura mais curtos para atingir as resistências e estrutura de poros desejada. Este mesmo comportamento não ocorre com as pozolanas naturais, escórias e cinzas volantes. 
Concreto sem Sílica Ativa

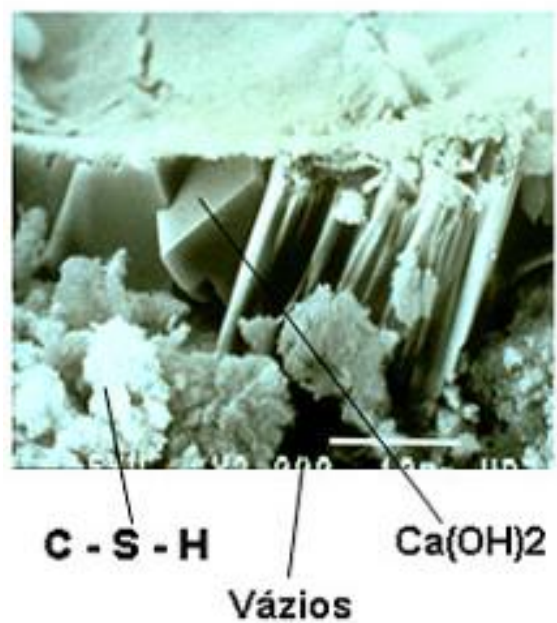

\section{Concreto com Sílica Ativa}

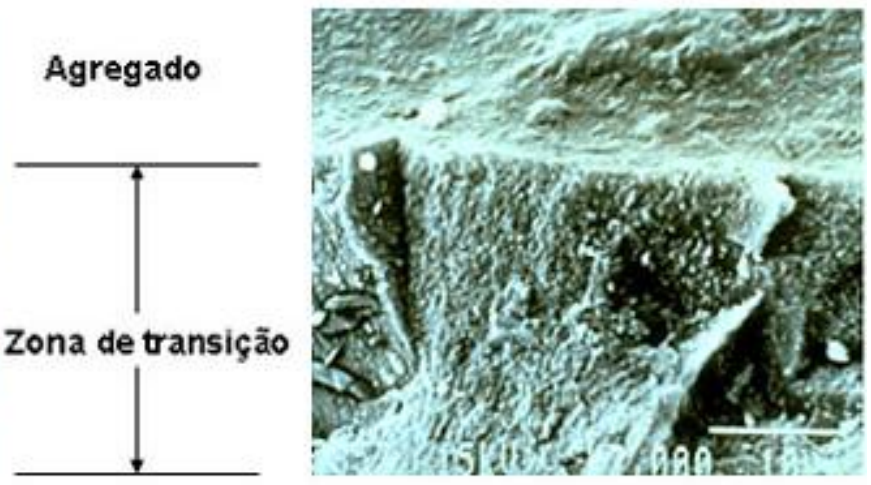

Figura 2.13 - Ação química ou pozolânica (TECNOSIL, 2008)

Normalmente, a dosagem de sílica ativa é expressa em porcentagem da massa de cimento utilizada no traço em questão. Em ambientes laboratoriais, a taxa pode variar de 25 a $30 \%$ para fixar todo o potencial de cal liberada pela hidratação do $\mathrm{C}_{3} \mathrm{~S}$ e do $\mathrm{C}_{2} \mathrm{~S}$. Porém essa medida é inviável no meio prático, já que elevaria muito o consumo de superplastificante e com isso, o custo do concreto. Por isso, recomenda-se uma quantidade variando de 3 a $10 \%$ da massa de cimento. Superior a essa taxa a relação custo $\mathrm{x}$ benefício fica prejudicada, já que extrapolando o limite de $10 \%$ há muito pouco ganho de resistência.

Seus benefícios aparecem especialmente entre 7 e 28 dias com o aumento da resistência à compressão. O produto é normatizado pela ABNT, conforme normas ABNT NBR 13956 e ABNT NBR 13957.

\subsection{Laminado}

Os polímeros reforçados com fibras (PRF) são considerados materiais compósitos. Ou seja, são compostos por dois materiais diferentes, sendo um classificado como matriz e o outro classificado como reforço. Nesse caso, a matriz são as resinas, responsáveis por envolver e unir o reforço, permitindo boa transferência de tensões. $\mathrm{O}$ reforço são as fibras propriamente ditas, de pequeno diâmetro, alta resistência e elevado módulo de elasticidade. Os polímeros são materiais compósitos não homogêneos, anisotrópicos e de comportamento perfeitamente elásticos até a ruína. 
Para Soares e Martins (2006), a eficiência dos polímeros reforçados com fibras, depende da escolha apropriada de seus constituintes, destacando-se: as propriedades, o comprimento, a orientação, a forma, a concentração e a composição das fibras, as propriedades mecânicas da matriz, as propriedades mecânicas do adesivo, a adesão entre fibras e matriz, a proporção da mistura e o método de aplicação. Juvandes (1999) explica que a resistência à tração e o módulo de elasticidade são máximos para a direção principal das fibras e reduzem proporcionalmente de valor, quando o ângulo das fibras se afasta daquela direção.

De todas as fibras disponíveis (vidro, carbono e aramida, por exemplo), os filamentos de carbono são os mais apropriados para reforço de estruturas em concreto armado. Características como alta resistência à tração, elevado módulo de elasticidade, resistência à fadiga, leveza, durabilidade, resistência à corrosão e resistência à elevada temperatura, fazem deles uma boa opção para a construção civil.

As principais formas de comercialização dos polímeros reforçados com fibra de carbono (PRFC), como comentado na seção 1.2, são: unidirecionais, bidirecionais ou multidirecionais, de acordo com a distribuição das fibras. Ainda podem ser classificados em sistemas pré-fabricados ou curados “in situ”. Nesse trabalho, interessará estudar o PRFC unidirecional pré-fabricado, na forma de laminado.

Os laminados "resultam da impregnação de um conjunto de feixes ou camadas contínuas de fibras por uma resina termoendurecível, consolidadas por um processo de pultrusão com controle da espessura e da largura do compósito.” (JUVANDES, 1999, p.2.21). A Figura 2.14 representa o aspecto geral de um sistema de PRF pré-fabricado:

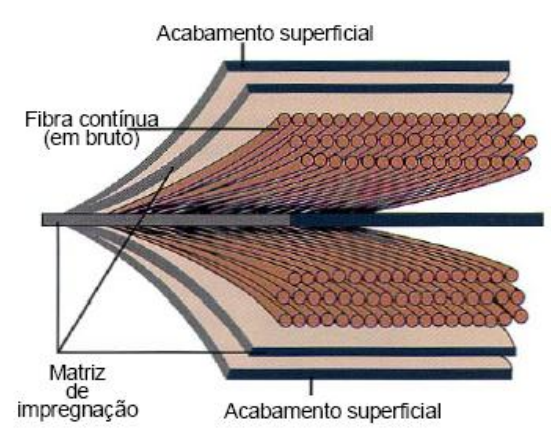

a) fases do laminado

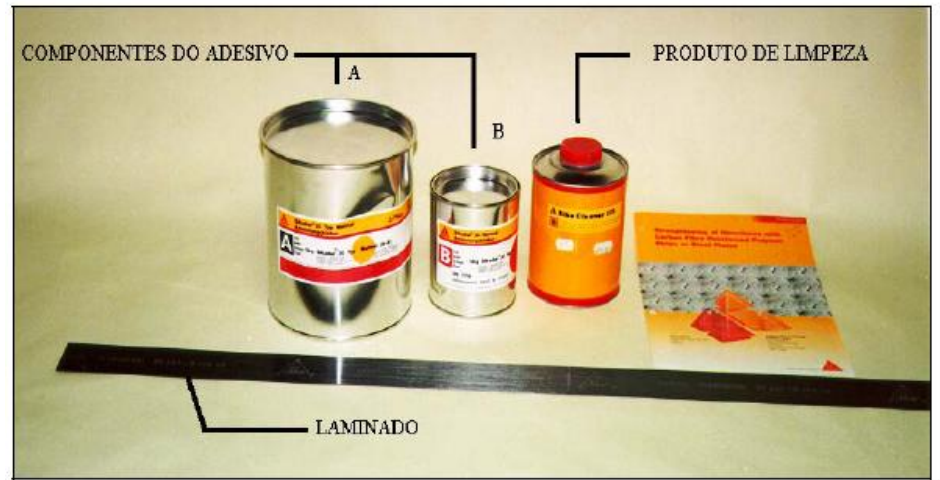

b) componentes de um sistema laminado de PRFC

Figura 2.14 - Aspecto geral de um sistema de PRFC pré-fabricado (Adaptado de JUVANDES, 1999, p.2.22) 
A orientação unidirecional das fibras do laminado lhe confere a maximização da resistência e da rigidez na direção longitudinal. Por isso, ele é indicado para esforços provenientes de momento fletor e cisalhamento, por exemplo.

Os polímeros são fixados às estruturas por resinas. Logo, o desempenho final do reforço, depende do comportamento, a curto e longo prazo, dos dois materiais. A resina, por exemplo, tem limitada resistência ao fogo, no entanto, essas consequiências são levadas em consideração pelos coeficientes de segurança.

\subsubsection{Produção das fibras}

Segundo Soares e Martins (2006), as fibras são produzidas através de um processo de carbonatação (grafitização) a uma temperatura entre $1000{ }^{\circ} \mathrm{C}$ e $3000{ }^{\circ} \mathrm{C}$, "adicionando-se átomos de carbono ao longo de fibras de polímeros orgânicos", que podem ser vidro ou peças em acrílico, por exemplo.

A microestrutura das fibras pode classificá-las em dois tipos: o carbono de elevado módulo de elasticidade (HM) e o carbono de elevada resistência (HS). A resistência e o módulo de elasticidade são extremamente influenciados pela temperatura de carbonatação final. Com o aumento da temperatura, a resistência da fibra aumenta até uma faixa entre 1300 e $1500{ }^{\circ} \mathrm{C}$. Depois disso, a resistência decresce devido ao surgimento de falhas, conforme aumenta o número de camadas de carbono.

A Figura 2.15 apresenta um modelo da seção transversal da fibra de carbono. Nota-se uma textura radial no centro e uma orientação circunferencial na região superficial.

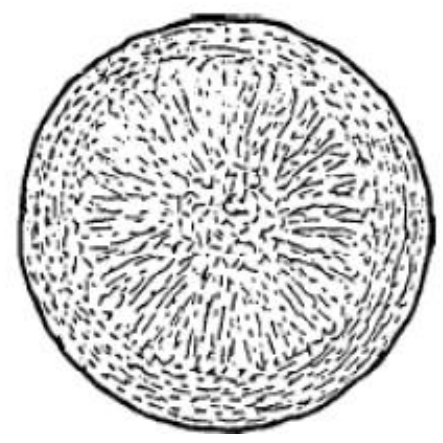

Figura 2.15 - Modelo da seção transversal da fibra de carbono (Adaptado de SOARES E MARTINS, 2006, p.26) 


\subsubsection{Matriz}

Para que as fibras possam funcionar corretamente, é imprescindível que a matriz apresente propriedades satisfatórias. É ela quem transmite os esforços entre as fibras, protege as fibras das agressividades ambientais (físicas ou químicas), de danos mecânicos e auxilia na resistência ao cisalhamento dos polímeros, seja no plano ou interlaminar. Além disso, dá suporte contra a instabilidade das fibras sob ações de compressão. (SOARES; MARTINS, 2006).

As matrizes podem ser do tipo termoendurecíveis ou termoplásticas. No primeiro caso, o compósito é curado pela ação de calor ou tratamento químico, transformando-se num produto infusível ou insolúvel, com uma estrutura molecular tridimensional complexa. No segundo, o compósito torna-se um produto plástico quando aquecido e rígido quando arrefecido, com uma estrutura molecular disposta linearmente. Por essas diferenças, a escolha da matriz influencia no custo final do PRF, sendo a termoendurecível do tipo epóxi a mais indicada e também a mais cara.

\subsubsection{Fatores Condicionantes}

O comportamento dos polímeros pode sofrer alteração dependendo das condições à que estão sujeitos. Os principais itens que podem intervir no desempenho do reforço estrutural estão listados abaixo:

- umidade e temperatura: essas condições ambientais são mais significativas para a matriz termoendurecível, causando uma aceleração na deteriorização do material. Em locais onde ocorre gelo e desgelo, a escolha correta do polímero é imprescindível. Por isso, é fundamental que o profissional se informe junto ao fornecedor sobre essas recomendações;

- comportamento à fluência e à relaxação: os polímeros menos influenciados por este comportamento são os unidirecionais. A deterioração do reforço pode acontecer através do aumento de tensões de tração, associado a um ambiente úmido ou agressivo quimicamente, que provoca o amolecimento da resina da matriz, com conseqüente diminuição da ligação interlaminar. Posteriormente, ocorre a antecipação da ruína por fluência;

- radiações ultravioleta: a presença desses raios pode provocar reações químicas na matriz do compósito, causando a deterioração do material. Mas, a solução é bastante simples e 
pode ser conquistada através da proteção do polímero com o uso de tintas de base aquosa ou de base em solventes, resina epóxi ou mesmo, argamassas hidráulicas;

- comportamento ao fogo: o efeito do fogo, por um período de tempo, pode comprometer o reforço através da dissolução da matriz termoendurecível. É interessante que haja uma proteção do polímero, sobretudo para reforço com aderência externa.

\subsection{Resina Epóxi}

As resinas são materiais usados como ponte de aderência entre dois elementos, sendo em geral um deles a superfície do concreto velho. A palavra epóxi vem do grego "EP" (sobre ou entre) e do inglês "OXI" (oxigênio). Em um sentido geral, o termo refere-se a um grupo constituído por um átomo de oxigênio ligado a dois átomos de carbono. As resinas epóxi são resinas sintéticas bastante diversificadas em relação às suas propriedades e são encontradas desde o estado líquido com baixa viscosidade e sem solvente até sólidas com alto ponto de fusão.

Helene (1995) e Konrad (2003) relatam que o inventor desse material foi o Dr. Pierre Castan em 1936 na Suíça, que trabalhava para a companhia De Trey Frères e desenvolvia um produto para a fabricação de dentaduras e outras próteses odontológicas. Segundo Konrad (2003), posteriormente sua patente foi adquirida pela empresa Ciba Pharma \& Plastics Ltd (atual Huntsman) que, após apreciável trabalho de pesquisa e desenvolvimento, lançou o epóxi para aplicação industrial, inicialmente como adesivo, o Araldite.

De lá para cá, os produtos se popularizaram no mercado da construção civil e segundo Helene (1995) estão cada vez mais, sendo utilizados em função com maior responsabilidade, como por exemplo, na construção de elementos pré-fabricados, na correção de manifestações patológicas (reforços estruturais, preenchimento de fissuras e juntas de concreto novo com antigo), em pisos industriais, entre outras aplicações.

As resinas epóxi são bi-componentes (resina e endurecedor) e são formadas pela reação química do oxigênio contido na resina com o hidrogênio das aminas contidas no endurecedor. É essa mistura, recomendada de acordo com cada fabricante, que garante a qualidade do produto final. Qualquer molécula do primeiro componente deve estabelecer ligação com as moléculas do segundo componente. Esta mistura está condicionada ao tempo de mistura, à temperatura e à umidade local (JUVANDES, 1999). 
Dois termos são importantes no contexto das resinas: tempo de utilização ("pot life") e tempo de contato (“open time”). O primeiro refere-se ao tempo de manuseio a partir do início da mistura. É mais curto a altas temperaturas e maior sob baixas temperaturas. Quanto maior a quantidade misturada, mais curto o tempo de manuseio, já que a reação é exotérmica (com liberação de calor). Como alternativa, é possível resfriar os componentes antes de misturá-los. Esgotado o tempo de manuseio, a mistura perde drasticamente suas características de aderência. $\mathrm{O}$ segundo refere-se ao intervalo de tempo que decorre entre a aplicação e o início do endurecimento. É diretamente influenciado pela temperatura do ambiente e da superfície de aplicação.

Por apresentarem elevada adesão ao concreto, elevada resistência mecânica, serem impermeáveis e possuírem elevada durabilidade ao ataque químico (resistem a solventes e muitos produtos químicos), as resinas epoxídicas são as responsáveis pela ligação entre o laminado de polímero reforçado com fibra de carbono e o entalhe realizado no cobrimento de concreto, através da técnica de NSM. Mas, segundo De Lorezins e Teng (2007), na tentativa de baixar o custo do reforço, reduzir o perigo para os trabalhadores, minimizar o impacto ambiental, permitir a ligação efetiva a substratos úmidos, conseguir uma melhor resistência a altas temperaturas e melhorar a compatibilidade com o substrato de concreto, o uso de pasta de cimento ou argamassa está sendo explorado. Porém, tanto esses autores como De Lorenzis e Rizzo (2004) relatam a inferioridade significativa das propriedades mecânicas desse material em comparação com os resultados obtidos com resinas epóxi.

Atenção especial deve ser tomada na escolha dessas resinas, já que existem diversas formulações e viscosidades no mercado. Existe também a possibilidade de adicionar solventes, flexibilizantes e pigmentos nas resinas para obter compósitos específicos para cada aplicação (JUVANDES, 1999). Helene (1995) diz que a formação do engenheiro civil é insuficiente para entender as complexas formulações das resinas além de se deparar com os sigilos industriais dos fabricantes. A escolha incorreta da resina pode reduzir a eficiência do reforço estrutural, como será comentado na seção 2.7.1.4, ou mesmo levar a estrutura ao colapso.

Segundo Juvandes (1999) todas as formulações poliméricas são higroscópicas, ou seja, absorvem umidade. Por isso, certas formulações não podem ser aplicadas em substratos já úmidos (KAZMIERCZAK, 2005). Como resultado, pode haver redução de até $50 \%$ na resistência à flexão em comparação com o estado seco. Felizmente esse efeito é reversível e 
como os efeitos de encurtamento e alongamento são muito pequenos, a influência destes parâmetros nas propriedades mecânicas da resina é desprezível.

Em contrapartida, outras desvantagens das resinas são preocupantes como: a sensibilidade à ambientes alcalinos e ácidos, as reações álcalis-sílica com constituintes do concreto, as ações de vento e poeiras ambientais e a condutividade elétrica. Kazmierczak (2005) completa esse cenário falando da dificuldade de repintura da estrutura reforçada e alerta para o principal problema: a tendência à deterioração quando expostas a radiação ultravioleta, em ambientes externos. Contudo Juvandes (1999) faz uma ressalva pertinente: um bom técnico pode introduzir um aditivo para proteger a composição, o que explicaria a troca do aço por materiais compósitos na indústria de aeronaves que está muito mais susceptível à exposição solar que uma estrutura reforçada, mesmo que em ambiente externo.

\subsection{Reforço com laminado de PRFC inserido no cobrimento de concreto}

A técnica conhecida por Near Surface Mounted (NSM), que na livre tradução quer dizer abertura próxima à superfície, iniciou-se na Europa e é conhecida desde 1947. O primeiro trabalho relatado foi de Asplund (1949 apud HASSAN e RIZKALLA, 2003, p.248), que estudou vigas reforçadas à flexão com aço inserido em ranhura executada no concreto e aderido a este com argamassa. Suas análises concluíram que as vigas reforçadas tiveram resultados idênticos aos das vigas de referência.

Mais tarde, Blaschko (1999) estudou a mesma técnica trocando o aço por laminado de polímero reforçado com fibra de carbono (PRFC). Sua pesquisa foi baseada no reforço ao cisalhamento de viga de concreto armado e concluiu que a técnica NSM tem maior capacidade de ancoragem em comparação com o mesmo material colado externamente.

A ranhura executada no elemento de concreto, que a partir de agora recebe o nome de entalhe, localiza-se no cobrimento das armaduras, ou seja, entre a face externa do concreto e a armadura mais externa da peça (Figura 2.16).

ASPLUND, S. O. (1949). Strengthening bridge slabs with grouted reinforcement. ACI Struct. J., 20(4) 397406. 


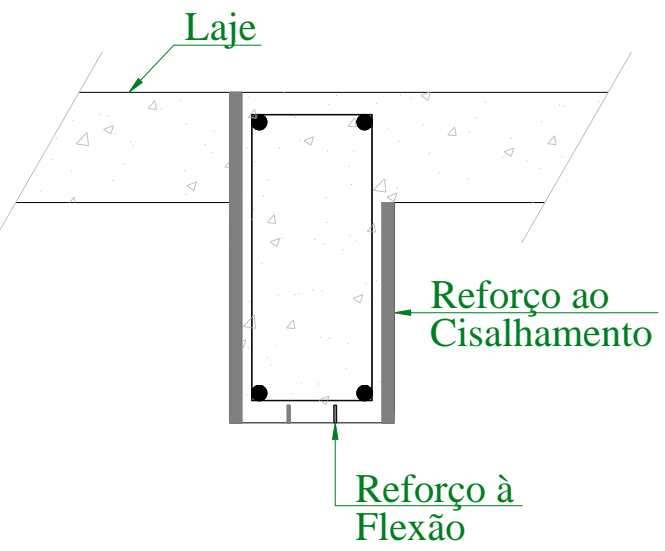

Figura 2.16 - Sistema de reforço à flexão e ao cisalhamento através da técnica NSM

A técnica NSM veio para suprir uma deficiência encontrada no sistema de colagem externa, que é o desprendimento prematuro do reforço. Com dupla área de aderência entre laminado e concreto, há um melhor aproveitamento do material sem esse inconveniente discriminado por qualquer engenheiro. Outras vantagens também são associadas a essa técnica, como proteção ao vandalismo, ao fogo e aos raios ultravioleta.

Atualmente, os laminados são fixados ao concreto por intermédio de um adesivo epóxi. Por ficarem quase imperceptíveis após o acabamento final, são indicados para recuperação de patrimônios históricos.

Nesse contexto, diversos grupos de pesquisa se motivaram a estudar o reforço tanto em vigas (lajes) quanto em pilares, tanto à flexão quanto ao esforço cortante. Obras reforçadas estão sendo monitoradas por sensores de fibra óptica, que podem ser estruturalmente integrados durante o processo de fabricação de barras e laminados de polímeros reforçados com fibra (PRF).

No Brasil, a falta de normalização é uma barreira à técnica NSM. Países como Japão e Canadá já estabeleceram procedimentos de projeto específicos para a utilização do reforço de PRF em estruturas de concreto. Nos Estados Unidos, as fases de análises e ensaios experimentais estão suficientemente completas, e os esforços estão sendo feitos para estabelecer as recomendações para projeto. O Comitê 440 do American Concrete Institute é o responsável por essa elaboração através do guia 440.1R (“Guia para concepção e construção de estruturas de concreto reforçado com barras de PRF"). 
Uma norma específica para estrutura reforçada com PRF se faz necessária, já que o comportamento mecânico do reforço é diferente do comportamento do aço. Duas características são fundamentais para esse esclarecimento: os compósitos são anisotrópicos, por isso, apresentam resistência à tração apenas na direção de orientação das fibras e, além disso, possuem comportamento elástico, portanto sem patamar de escoamento, gerando elementos reforçados frágeis. Essas incompatibilidades entre os materiais evidenciam a necessidade de mudanças na filosofia do projeto de estruturas de concreto armado reforçados com polímeros.

\subsubsection{Trabalhos anteriores que utilizaram a técnica NSM}

Nesta seção serão expostos alguns trabalhos que utilizaram a técnica NSM. Resultados interessantes foram obtidos tanto em reforço ao cisalhamento quanto à flexão e serão apresentados nas seções 2.7.1.1 e 2.7.1.2.

\subsubsection{Reforço ao cisalhamento}

Dias e Barros (2004) compararam vigas reforçadas com estribos convencionais de aço, mantas aderidas externamente e laminados inseridos no cobrimento de concreto (entalhes verticais e entalhes inclinados). Para isso realizaram duas séries de ensaios, A e B. Na primeira série as vigas tinham seção de 15 x $30 \mathrm{~cm}$ e $1,5 \mathrm{~m}$ de vão e na segunda, tinham seção 15 x $15 \mathrm{~cm}$ e $0,90 \mathrm{~m}$ de vão. Em cada uma das séries foram considerados dois tipos de armaduras longitudinais na face tracionada: $4 \Phi 10$ e 4Ф12. Após realizarem ensaio à flexão em quatro pontos de carga, os resultados foram os seguintes (Tabela 2.4):

Tabela 2.4 - Principais resultados dos ensaios das vigas ensaiadas (DIAS; BARROS, 2004, p. 5)

\begin{tabular}{|c|c|c|c|c|c|c|c|}
\hline $\begin{array}{c}\text { Vigas } \\
\text { (Série A: } \\
\text { 4Ф10) }\end{array}$ & $\begin{array}{c}\text { Reforço ao } \\
\text { Corte }\end{array}$ & $\begin{array}{l}F_{\text {máx }} \\
(\mathbf{k N})\end{array}$ & $\begin{array}{c}F_{\text {máx }} / F_{\text {máx }}, \\
\quad V A 10\end{array}$ & $\begin{array}{c}F_{\text {máx }} / F_{\text {máx }}, \\
\quad V A E-30\end{array}$ & $\delta_{P}(\mathbf{m m})$ & $\begin{array}{c}\delta_{P} / \delta_{P, V A 10} \\
(\mathbf{m m})\end{array}$ & $\begin{array}{c}\delta_{P} / \\
\delta_{P, V A E-30} \\
(\mathrm{~mm})\end{array}$ \\
\hline VA10 & - & 100,40 & 1,00 & 0,59 & 2,80 & 1,00 & 0,17 \\
\hline VAE-30 & Estribos & 169,35 & 1,69 & 1,00 & 16,25 & 5,80 & 1,00 \\
\hline VAM-19 & Manta & 122,06 & 1,22 & 0,72 & 3,75 & 1,34 & 0,23 \\
\hline VACV-20 & $\begin{array}{c}\text { Laminados } \\
\text { Verticais }\end{array}$ & 158,64 & 1,58 & 0,94 & 12,86 & 4,59 & 0,79 \\
\hline VACI-30 & $\begin{array}{l}\text { Laminados } \\
\text { Inclinados }\end{array}$ & 157,90 & 1,57 & 0,93 & 30,96 & 11,06 & 1,91 \\
\hline
\end{tabular}


Capítulo 2 - Revisão Bibliográfica

\begin{tabular}{|c|c|c|c|c|c|c|c|}
\hline $\begin{array}{c}\text { Vigas } \\
\text { (Série A: } \\
\text { 4Ф12) }\end{array}$ & $\begin{array}{c}\text { Reforço ao } \\
\text { Corte }\end{array}$ & $\begin{array}{l}F_{\text {máx }} \\
(\mathbf{k N})\end{array}$ & $\begin{array}{c}F_{\text {máx }} / F_{\text {máx }}, \\
\quad \text { VA12 }\end{array}$ & $\begin{array}{c}F_{\text {máx }} / F_{\text {máx }}, \\
\quad \text { VAE-15 }\end{array}$ & $\delta_{P}(\mathbf{m m})$ & $\begin{array}{c}\delta_{P} / \delta_{P, V A 12} \\
(\mathbf{m m})\end{array}$ & $\begin{array}{c}\delta_{P} / \\
\delta_{P, V A E-15} \\
(\mathbf{m m})\end{array}$ \\
\hline VA12 & - & 116,50 & 1,00 & 0,54 & 2,74 & 1,00 & 0,43 \\
\hline VAE-15 & Estribos & 215,04 & 1,85 & 1,00 & 6,34 & 2,31 & 1,00 \\
\hline VAM-9,5 & Manta & 179,54 & 1,54 & 0,83 & 4,91 & 1,79 & 0,77 \\
\hline VACV-10 & $\begin{array}{l}\text { Laminados } \\
\text { Verticais }\end{array}$ & 235,11 & 2,02 & 1,09 & 6,70 & 2,45 & 1,06 \\
\hline VACI-15 & $\begin{array}{l}\text { Laminados } \\
\text { Inclinados }\end{array}$ & 262,38 & 2,25 & 1,22 & 11,75 & 4,29 & 1,85 \\
\hline $\begin{array}{c}\text { Vigas } \\
\text { (Série B: } \\
\text { 4Ф10) }\end{array}$ & $\begin{array}{c}\text { Reforço ao } \\
\text { Corte }\end{array}$ & $\begin{array}{l}F_{\text {máx }} \\
(\mathbf{k N})\end{array}$ & $\begin{array}{c}F_{m a ́ x} / F_{m a ́ x}, \\
V B 10\end{array}$ & $\begin{array}{c}F_{\text {máx }} / F_{\text {máx }}, \\
\quad V B E-15\end{array}$ & $\delta_{P}(\mathbf{m m})$ & $\begin{array}{c}\delta_{P} / \delta_{P, V B 10} \\
\quad(\mathbf{m m})\end{array}$ & $\begin{array}{c}\delta_{P} / \\
\delta_{P, V B E-15} \\
(\mathbf{m m})\end{array}$ \\
\hline VB10 & - & 74,02 & 1,00 & 0,61 & 2,00 & 1,00 & 0,23 \\
\hline VBE-15 & Estribos & 120,64 & 1,63 & 1,00 & 8,53 & 4,27 & 1,00 \\
\hline VBM-8 & Manta & 111,14 & 1,50 & 0,92 & 4,40 & 2,20 & 0,52 \\
\hline VBCV-10 & $\begin{array}{l}\text { Laminados } \\
\text { Verticais }\end{array}$ & 131,22 & 1,77 & 1,09 & 6,83 & 3,42 & 0,80 \\
\hline VBCI-15 & $\begin{array}{l}\text { Laminados } \\
\text { Inclinados }\end{array}$ & 120,44 & 1,63 & 1,00 & 4,27 & 2,14 & 0,50 \\
\hline $\begin{array}{c}\text { Vigas } \\
\text { (Série B: } \\
\text { 4Ф12) }\end{array}$ & $\begin{array}{c}\text { Reforço ao } \\
\text { Corte }\end{array}$ & $\begin{array}{l}F_{\text {máx }} \\
(\mathbf{k N})\end{array}$ & $\begin{array}{c}F_{m a ́ x} / F_{m a ́ x}, \\
\quad V B 12\end{array}$ & $\begin{array}{c}F_{\text {máx }} / F_{\text {máx }}, \\
\quad V B E-7,5\end{array}$ & $\delta_{P}(\mathbf{m m})$ & $\begin{array}{c}\delta_{P} / \delta_{P, V B 12} \\
\quad(\mathbf{m m})\end{array}$ & $\begin{array}{c}\delta_{P} / \\
\delta_{P, V B E-7,5} \\
(\mathbf{m m})\end{array}$ \\
\hline VB12 & - & 75,7 & 1,00 & 0,48 & 2,03 & 1,00 & 0,40 \\
\hline VBE-7,5 & Estribos & 159,1 & 2,10 & 1,00 & 5,09 & 2,51 & 1,00 \\
\hline VBM-4 & Manta & 143,0 & 1,89 & 0,90 & 3,52 & 1,73 & 0,69 \\
\hline VBCV-5 & $\begin{array}{c}\text { Laminados } \\
\text { Verticais }\end{array}$ & 139,2 & 1,84 & 0,87 & 4,44 & 2,19 & 0,87 \\
\hline VBCI-7,5 & $\begin{array}{l}\text { Laminados } \\
\text { Inclinados }\end{array}$ & 148,5 & 1,96 & 0,93 & 4,92 & 2,42 & 0,97 \\
\hline
\end{tabular}

Observa-se que a técnica com laminados inseridos apresentou evidentes melhoras nos resultados em termos de carga máxima e de deformação em comparação com as vigas de referência. A nova técnica aumentou em 83\% a carga máxima e em 307\% a deformação da viga, enquanto que o reforço com manta aumentou em $54 \%$ e $77 \%$, respectivamente. Os resultados comprovaram que a técnica de inserção de laminados proporcionou um comportamento menos frágil que àquela com uso de mantas coladas externamente. 


\subsubsection{Reforço à flexão}

Fortes (2004) realizou em seu trabalho uma comparação entre as técnicas de colagem interna de laminados e colagem externa de mantas e laminados de PRFC. Para isso, foram preparadas inicialmente duas séries (S1 e S2), na qual a primeira referia-se à técnica NSM e a segunda, à comparação entre as técnicas convencionais de colagem externa de laminados e mantas e a técnica NSM. Mais tarde, foi criada a série S3, semelhante a S1, porém com a viga mais larga e contendo os laminados externos menores que o laminado interno, com o intuito de diminuir as tensões nas extremidades laterais das vigas.

$\mathrm{Na}$ Tabela 2.5 encontra-se o resumo das quantidades, dimensões e técnicas utilizadas em cada série:

Tabela 2.5 - Resumo das características das três séries analisadas por Fortes (2004)

\begin{tabular}{c|c|c|c}
\hline Série & Quantidade & Seção $(\mathbf{m m})$ & Técnica \\
\hline S1 & 8 & $100 \times 170 \times 1600$ & NSM \\
\hline S2 & 24 & $120 \times 170 \times 1000$ & $\begin{array}{c}\text { Colagem Externa de } \\
\text { Manta e Laminado }\end{array}$ \\
\hline S3 & 6 & $120 \times 170 \times 1600$ & NSM \\
\hline
\end{tabular}

Fortes (2004) sugere a Equação 2.7 para calcular a taxa equivalente de armaduras (aço + fibras de carbono) a partir do conceito de seção homogeneizada. Na pesquisa foi observado que quanto maior essa taxa, maior é a carga de ruptura da viga reforçada. Isso, segundo o autor, "pode ser utilizado como parâmetro para indicar entre algumas opções de seção reforçada, qual a mais adequada" (FORTES, 2004, p. 29).

$$
\rho_{e q}=\left(\frac{A_{s}}{b . d_{s}}\right)+\left(\frac{A_{f} \frac{E_{f}}{E_{s}}}{b \cdot d_{f}}\right)
$$

onde:

$A_{s}=$ área de aço;

$b=$ largura da viga;

$d_{s}=$ altura útil da viga a partir do centro de gravidade da barra de aço; 
$A_{f}=$ área de fibra de carbono;

$d_{f}=$ altura útil da viga a partir do centro de gravidade do laminado;

$E_{f}=$ módulo de elasticidade do laminado;

$E_{s}=$ módulo de elasticidade do aço.

A Figura 2.17 representa a geometria das vigas, a disposição das armaduras convencionais e dos reforços, o esquema de carregamento e as condições de apoio do ensaio da série $\mathrm{S} 1$.
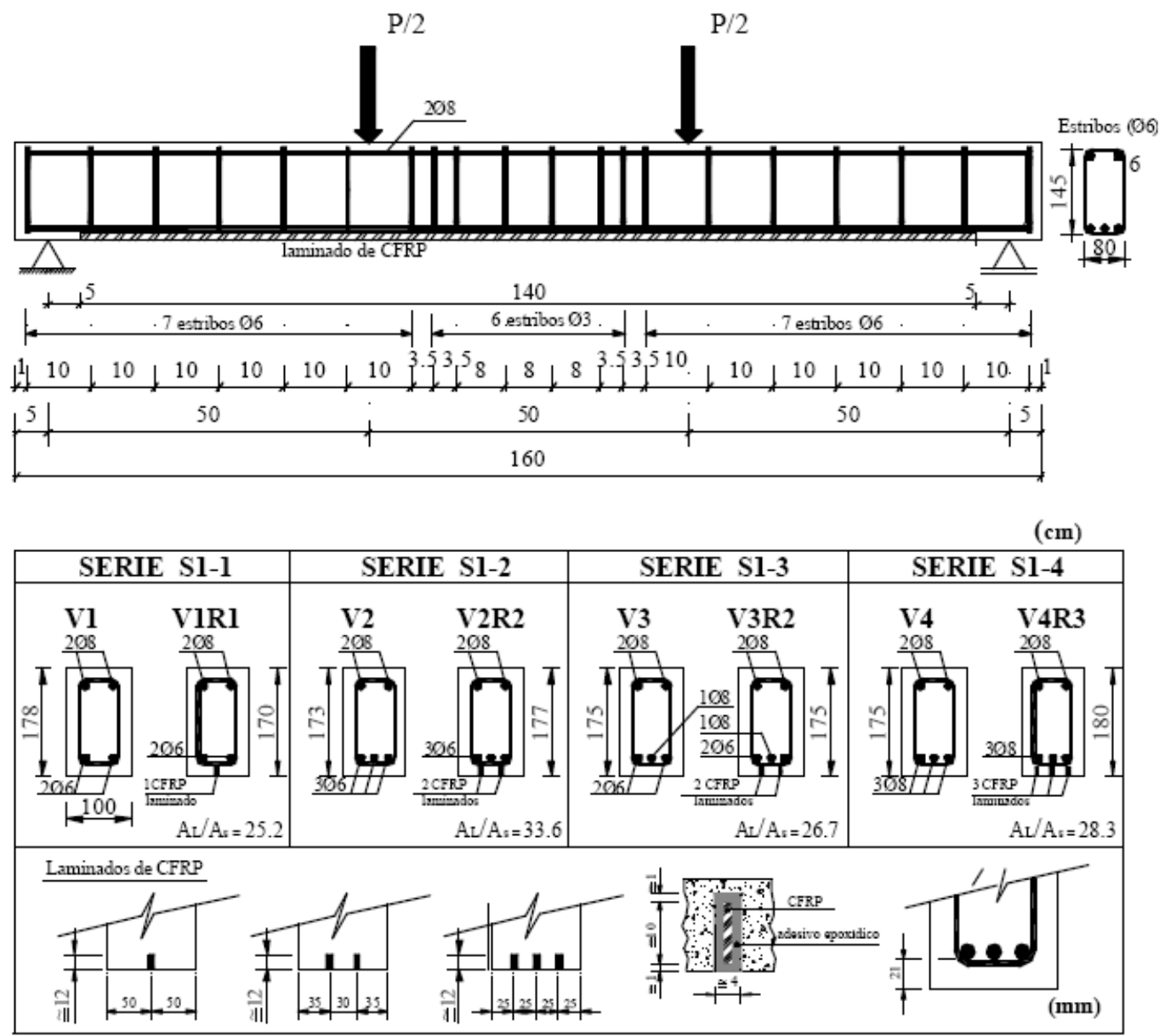

Figura 2.17 - Esquema de ensaio e detalhamento das vigas da série S1 (Adaptado de FORTES, 2004, p. 158)

A área de reforço foi calculada com o objetivo de duplicar a capacidade resistente das vigas. Como houve variação na taxa de armadura longitudinal, aumentou-se a quantidade de laminados inseridos (vigas com um, dois e três laminados). 
Verificou-se que esse objetivo foi praticamente alcançado, com aumento de até $96 \%$ da capacidade na série S1 e $95 \%$ na série S3.

Tanto na série S1 quanto na S3, o ganho nas capacidades de carga e rigidez, ambas de serviço, foi inferior aos respectivos valores últimos. Além disso, nas duas séries a capacidade do laminado foi mobilizada quase integralmente, variando entre $62 \%$ e $91 \%$ da deformação máxima. Na série $\mathrm{S} 1$, com exceção de uma viga, a ruptura deu-se por falha no concreto tracionado. As armaduras longitudinais ficaram expostas, com destacamento do concreto de cobrimento variando entre 5 e $6 \mathrm{~cm}$ de espessura. Observou-se que o laminado continuou aderido ao adesivo, que continha fragmentos de concreto. Pode-se concluir que o incremento de carga depende não somente da inserção de laminados, mas também da capacidade resistente à tração do concreto.

Na série S3, houve três formas diferentes de ruptura: deslizamento do laminado na região central com ruptura interlaminar, ruptura do concreto tracionado deixando à mostra a armadura longitudinal e ruptura dos laminados externos (menores), deixando íntegro o laminado central.

Na série S2, como comentado anteriormente, foi realizada uma comparação entre as três técnicas existentes com laminados e mantas de PRFC. As vigas de referência foram denominadas de $\mathrm{V}$, as vigas reforçadas com laminados inseridos em entalhes, de VLI, as vigas reforçadas com laminados colados externamente, de VLC e as vigas reforçadas com manta, de VM.

A Figura 2.18 representa as características, o esquema de carregamento e as condições de apoio do ensaio da série S2. 


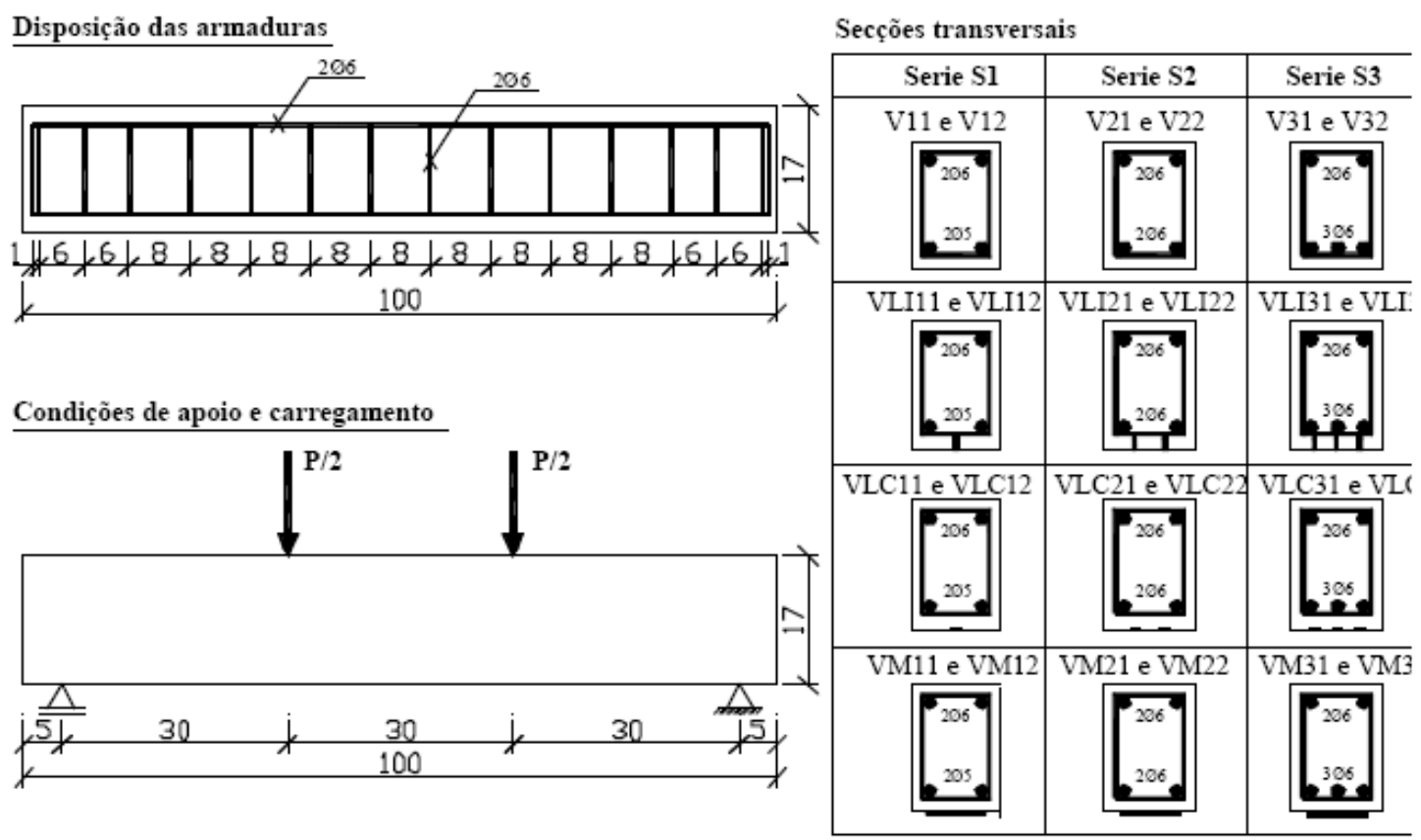

Figura 2.18 - Esquema de ensaio e detalhamento das vigas da série S2 (Adaptado de FORTES, 2004, p. 198)

A Tabela 2.6 apresenta as cargas de ruptura encontradas experimentalmente:

Tabela 2.6 - Cargas de ruptura obtidas experimentalmente na série S2 (Adaptado de FORTES, 2004, p. 203)

\begin{tabular}{c|c|c|c|c|c}
\hline \multicolumn{2}{c|}{ Série S2-1 } & \multicolumn{2}{c|}{ Série S2-2 } & \multicolumn{2}{c}{ Série S2-3 } \\
\hline Viga & $\mathbf{P}_{\mathbf{u}}(\mathbf{k N})$ & Viga & $\mathbf{P}_{\mathbf{u}}(\mathbf{k N})$ & Viga & $\mathbf{P}_{\mathbf{u}}(\mathbf{k N})$ \\
\hline V & 36,6 & V & 48,5 & V & 71,8 \\
\hline VLI & 79,9 & VLI & 93,3 & VLI & 96,6 \\
\hline VLC & 38,6 & VLC & 83,5 & VLC & 86,5 \\
\hline VM & 43,0 & VM & 79,5 & VM & 87,3 \\
\hline
\end{tabular}

É possível observar a eficácia da técnica NSM através das cargas últimas apresentadas. Na série S2-1, a carga aumentou $118 \%$ em comparação com a viga de referência. Por outro lado, quanto maior a taxa de armadura longitudinal, menor a eficiência do reforço. Na série S2-3 o aumento de carga foi de apenas 35\%. O mesmo ocorreu para as cargas de serviço. 
Assim como nas séries S1 e S3, o incremento da capacidade de carga de serviço da técnica NSM foi reduzido em comparação com a capacidade de carga última. Nesse quesito, a colagem de manta foi a mais eficiente das técnicas, seguida pela NSM.

$\mathrm{Na}$ série S2, todas as vigas reforçadas com a técnica NSM romperam por destacamento do concreto de cobrimento. A falha nas vigas reforçadas com uma e duas camadas de manta deu-se por ruptura da manta. Já os laminados aderidos externamente destacaram-se, do mesmo modo como ocorreu com as vigas reforçadas com três camadas de manta.

A carga de início de fissuração da técnica NSM foi retardada em comparação com os reforços externos. Das três técnicas estudadas, a de colagem externa de laminados apresentou os menores valores de carga de fissuração.

É natural que cada vez que se acrescenta um laminado no cobrimento de concreto, como fez Fortes (2004), a distância entre eles diminua. Bonaldo, Barros e Lourenço (2007) estudaram a influência dessa distância, com consequente estudo da taxa de reforço sobre o incremento de carga final da peça e a dependência da resistência do concreto. Eles utilizaram quinze lajes com três resistências de concreto diferentes (C12/16, C35/45 e C50/60), reforçadas conforme as cinco maneiras abaixo descritas (Figura 2.19): 


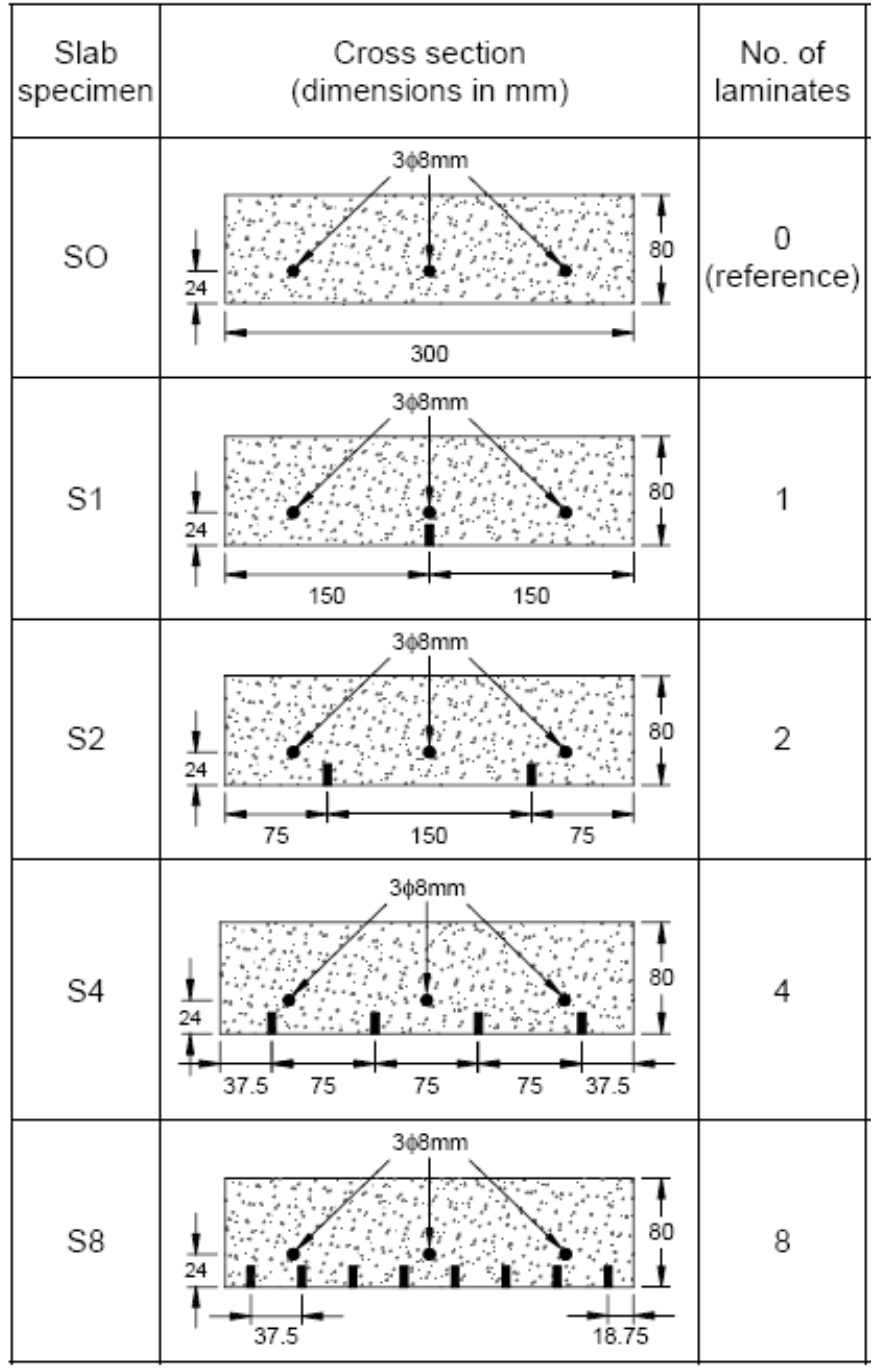

Figura 2.19 - Configuração das lajes reforçadas (Adaptado de BONALDO; BARROS; LOURENÇO, 2007, p. 2)

Os autores concluíram que o aumento da taxa de reforço favorece o destacamento do cobrimento de concreto. Isso pode ocorrer pelas altas tensões de aderência instaladas no concreto compreendido entre os laminados, nas extremidades longitudinais do laminado ou devido à formação de uma fissura de cisalhamento. Os fenômenos são afetados pela distância entre laminados, a classe do concreto e a porcentagem de armadura de aço convencional disposta longitudinalmente.

O trabalho de Bonaldo, Barros e Lourenço (2007), discute o limite de reforço para as respectivas resistências de concreto. Classe de concreto com baixa resistência, por exemplo, fica limitada à sua tensão de esmagamento.

Esse tipo de transtorno pode ser evitado, segundo Bonaldo, Barros e Lourenço (2006), com o uso de um concreto mais resistente na parte comprimida, que pode ser conquistado 
com a adição de fibras de aço. Eles descrevem que em faixas de lajes com 1,80 m, taxa de armadura longitudinal de $0,63 \%$ e taxa de reforço com laminado de 0,25\%, houve um aumento de 55\% na carga de serviço em relação à laje sem reforço. Esse valor aumentou para 244\% quando utilizaram o sistema híbrido de reforço, ou seja, com adição do concreto reforçado com fibras de aço. Além disso, houve aumento de $122 \%$ na carga correspondente à flecha para estados limites de utilização e uma melhor distribuição das fissuras, com maior número de aberturas de menores espessuras.

Uma comparação entre técnicas e materiais também foi realizada por Castro (2005), que estudou vigas "T" reforçadas com laminado e barra de PRFC inseridos em entalhes, barras de aço e de vidro na mesma situação e tecido de fibra de carbono aderido externamente. Foram criadas duas séries de vigas variando a taxa de armadura longitudinal ( $\rho$ $=0,63 \%$ e $\rho=1,57 \%$ ).

Pode-se concluir que, em geral, a técnica NSM apresentou melhor desempenho que a técnica de colagem externa de PRFC em vigas com menor taxa de armadura longitudinal, e o mesmo desempenho quando a taxa era a mais alta. $\mathrm{O}$ reforço com aço apresentou os piores resultados comparado às duas taxas.

Os modos de ruptura nos reforços com PRF (carbono e vidro) foram sempre frágeis, independentemente da técnica utilizada. Foram observadas rupturas por destacamento do cobrimento de concreto, descolamento ou ruptura do reforço e esmagamento do concreto. No caso das barras de polímeros reforçados com fibras de vidro (PRFV) e de laminados de PRFC inseridos em entalhes, as deformações do reforço foram superiores a $11 \%$ antes do destacamento do cobrimento de concreto. Particularmente, as vigas reforçadas com os laminados de PRFC tiveram incremento de carga última de $34 \%$ para as vigas com baixa taxa de armadura e de $25 \%$ para a alta taxa. Isso demonstra que o reforço nas vigas com menor taxa de armadura é mais eficiente comparado ao reforço com taxa mais alta, já que pode haver esmagamento do concreto antes mesmo de desenvolver toda a resistência do reforço.

Nenhuma das técnicas aumentou significativamente a rigidez das vigas na fase pósfissuração, mas observou-se maior diferença nas vigas reforçadas com baixa taxa de armadura.

Continuando os estudos com vigas “T”, El-Hacha e Rizkalla (2004) realizaram um programa experimental composto por oito vigas, sob carga concentrada ao meio do vão. A Figura 2.20 representa o esquema de ensaio, assim como as dimensões e armaduras das vigas: 


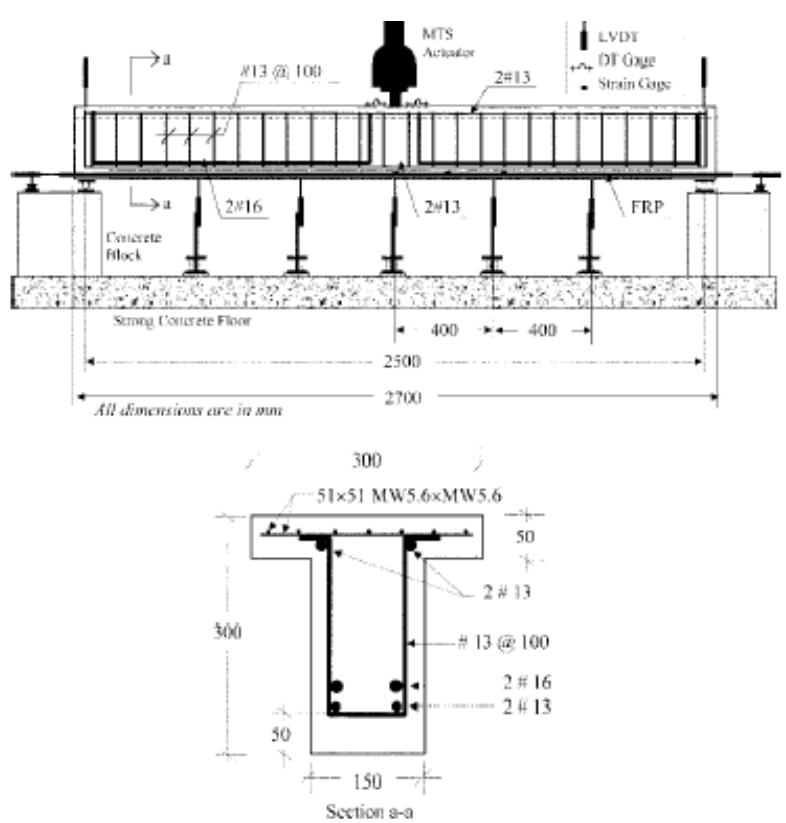

Figura 2.20 - Representação do esquema de ensaio, dimensão e armadura das vigas (Adaptado de EL-HACHA; RIZKALLA, 2004, p. 719)

Nota-se que há uma redução de armadura no meio do vão. Isso foi planejado para que a ruptura por flexão ocorresse nessa seção e simulasse as condições reais de vigas com armaduras corroídas.

Das oito vigas analisadas, uma serviu como referência (sem reforço), quatro foram reforçadas com diferentes sistemas de NSM (barras e laminados de PRFC e laminados de PRFV) e três foram reforçadas com laminados de PRFC e PRFV colados externamente.

Pelos resultados obtidos, pode-se observar a superioridade da técnica NSM em comparação com os polímeros aderidos externamente. Houve aumento significativo na rigidez e na capacidade de carga final das vigas. Em comparação com a viga sem reforço, antes da primeira fissura aparecer, o comportamento das vigas era bastante semelhante. Após a primeira fissura, o reforço limitou as deflexões e diminuiu as aberturas das fissuras.

\subsubsection{Aderência}

No que diz respeito à técnica NSM, é notável que a aderência é a característica essencial para o correto funcionamento do reforço. Muitos pesquisadores trabalham para desvendar o que realmente ocorre na zona de ancoragem e como se dá a transmissão das 
tensões de cisalhamento do laminado para o concreto, passando pela resina. Por isso, faz-se uma exposição dos estudos realizados e das incompatibilidades encontradas pelos autores.

Os autores De Lorenzis e Teng (2007) relatam em seu trabalho muito mais que as características individuais dos materiais envolvidos. Para eles, o desempenho da ligação depende de parâmetros como as dimensões dos entalhes, as formas e dimensões dos laminados ou barras e o grau de rugosidade do entalhe.

Blaschko (2003) sugere que a profundidade $\left(h_{g}\right)$ e a largura $\left(b_{g}\right)$ do entalhe sejam aproximadamente $3 \mathrm{~mm}$ maiores que a altura e a espessura do laminado respectivamente, de maneira a obter uma camada adesiva com cerca de 1 a $2 \mathrm{~mm}$ de espessura. Outra recomendação é de Parretti e Nanni (2004) que dizem que a largura mínima $\left(b_{g}\right)$ do entalhe não deve ser inferior a três vezes a espessura do laminado e a profundidade mínima $\left(h_{g}\right)$ superior a uma vez e meia a altura do laminado.

Em relação ao posicionamento do entalhe na seção transversal da viga, Blaschko (2003) observou que seria necessária uma distância superior a $20 \mathrm{~mm}$ do canto da viga para que não houvesse destacamento do concreto e $30 \mathrm{~mm}$ para que não houvesse fissuras no concreto. Por isso, ele sugere que o entalhe se localize a uma distância $\left(a_{e}\right)$ não inferior a 30 mm ou ao diâmetro do agregado.

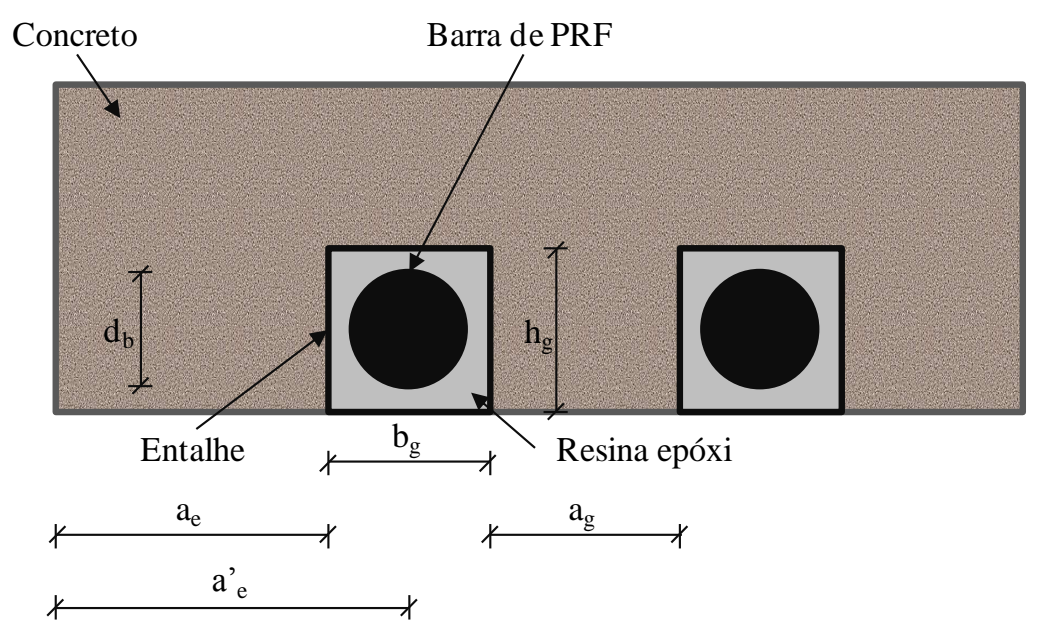

Figura 2.21 - Posicionamento do entalhe estudado por Blaschko (2003)

Depois de posicionar corretamente o laminado, é necessário descobrir o comprimento de ancoragem necessário para evitar o destacamento do laminado. Para avaliar a influência desse comprimento, Cruz e Barros (2002) propuseram um ensaio de aderência baseado na 
proposta da RILEM (1982) que caracteriza a ligação de armaduras convencionais ao concreto. $\mathrm{O}$ esquema de ensaio pode ser observado na Figura 2.22, porém maiores detalhes serão relatados no Capítulo 4:

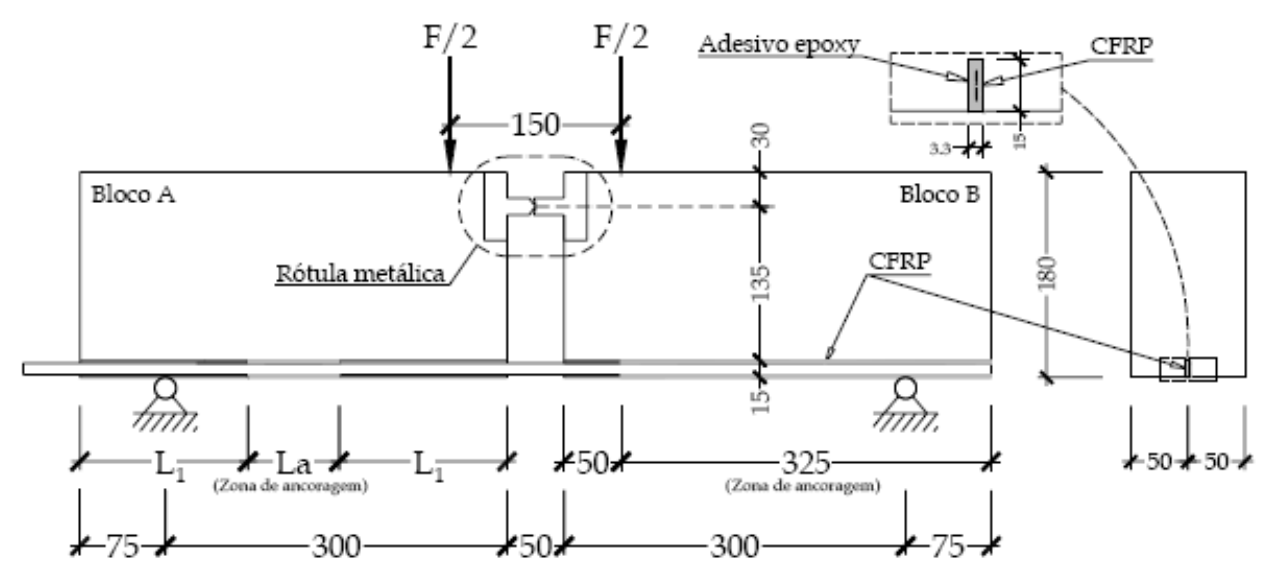

Figura 2.22 - Esquema do ensaio de aderência (Adaptado de CRUZ; BARROS, 2002, p. 10)

Os autores estudaram três comprimentos de ancoragem $(\mathrm{La}=40,60$ e $80 \mathrm{~mm})$ e três resistências de concreto $\left(\mathrm{f}_{\mathrm{ck}}=35,45\right.$ e $\left.70 \mathrm{MPa}\right)$, chegando às conclusões de que quando se aumenta o comprimento de ancoragem: a força máxima no laminado cresce proporcionalmente obtendo melhor aproveitamento do reforço, a tensão de cisalhamento diminui e o deslizamento do laminado cresce. Em relação à variação da resistência do concreto, não foi observada influência significativa na resposta final do ensaio. Sobre esse assunto, Bonaldo et al. (2005) realizaram ensaios de "pull-off" em concreto reforçado com fibras de aço sobre um substrato de concreto simples unidos por três adesivos epoxídicos diferentes. Foram realizadas seis séries de ensaios com as seguintes resistências do concreto (Tabela 2.7):

Tabela 2.7 - Resistências dos concretos (Adaptado de BONALDO et al., 2005, p. 3)

\begin{tabular}{c|c}
\hline $\begin{array}{c}\text { Concreto do Substrato } \\
\text { (concreto simples) }\end{array}$ & $\begin{array}{c}\text { Concreto Reforçado } \\
\text { com Fibras de Aço }\end{array}$ \\
\hline \multirow{2}{*}{$\mathrm{C} 16 / 20$} & $\mathrm{C} 20 / 25$ \\
\cline { 2 - 2 } & $\mathrm{C} 25 / 30$ \\
\hline \multirow{2}{*}{$\mathrm{C} 35 / 45$} & $\mathrm{C} 35 / 45$ \\
\cline { 2 - 2 } & $\mathrm{C} 45 / 55$ \\
\hline
\end{tabular}




\begin{tabular}{l|l}
\hline \multirow{2}{*}{$\mathrm{C} 55 / 67$} & $\mathrm{C} 55 / 67$ \\
\cline { 2 - 2 } & $\mathrm{C} 60 / 75$ \\
\hline
\end{tabular}

Os adesivos utilizados foram: Icosit $^{\circledR} \mathrm{K}(P 1)$, Sikadur ${ }^{\circledR} 32 \mathrm{~N}(P 2)$ e Sikatop ${ }^{\circledR}$ Amatec 110 EpoCem $^{\circledR}(P 3)$. A Figura 2.23 mostra os resultados obtidos:

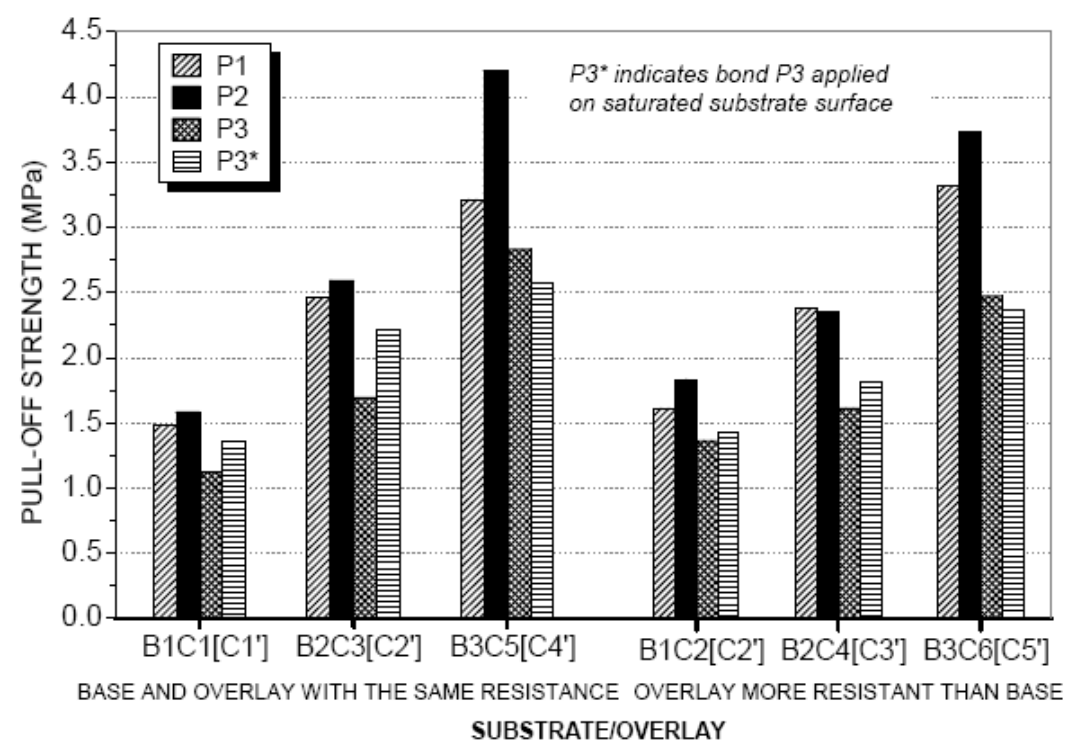

onde: $\mathrm{B}_{\mathrm{n}} \mathrm{C}_{\mathrm{m}}\left[\mathrm{C}_{\mathrm{m}}{ }^{\prime}\right]$ indica: $\mathrm{B}_{\mathrm{n}}$ é o concreto simples do substrato, $\mathrm{C}_{\mathrm{m}}$ é o concreto reforçado com fibra de aço e $\left[\mathrm{C}_{\mathrm{m}}{ }^{\prime}\right]$ é o concreto reforçado com fibra de aço colado com $\mathrm{P} 3$, na superfície do substrato saturado (P3*).

Figura 2.23 - Forças de arrancamento encontradas nos ensaios (Adaptado de BONALDO et al.,2005, p. 6)

O estudo revelou que as forças de arrancamento e os modos de falha são extremamente influenciados pela força de aderência dos adesivos, independentemente das resistências dos concretos. Em contrapartida, Hassan e Rizkalla (2002), embora não tenham realizado ensaios experimentais, acreditam que o concreto de alta resistência auxilia na resistência à ruptura do reforço. Essa explicação será relatada adiante.

Em outro trabalho, Cruz e Barros (2003) dizem que é fisicamente impossível instrumentar todo o comprimento de ancoragem para analisar a evolução das deformações. Entretanto, pelo ensaio de aderência, foi possível concluir que a distribuição das tensões de cisalhamento é essencialmente não linear em seu comprimento. Então, para entender melhor esse sistema de distribuição de tensões, os autores construíram um modelo analítico, utilizando como forma de calibração os resultados obtidos experimentalmente. A intenção era 
conhecer a relação entre a tensão de cisalhamento e o deslizamento ente laminado e concreto $(\tau-s)$. A equação diferencial utilizada foi a seguinte:

$$
\tau(x)=\frac{E_{f} \cdot t_{f}}{2} \cdot \frac{d \varepsilon_{f}}{d x}
$$

onde: $\tau(x)$ é a tensão de cisalhamento entre laminado e adesivo, $E_{f}$ é o módulo de elasticidade do laminado, $t_{f}$ é a espessura do laminado e $\varepsilon_{f}$ é a deformação do laminado.

A Figura 2.24 representa a condição de equilíbrio do laminado:
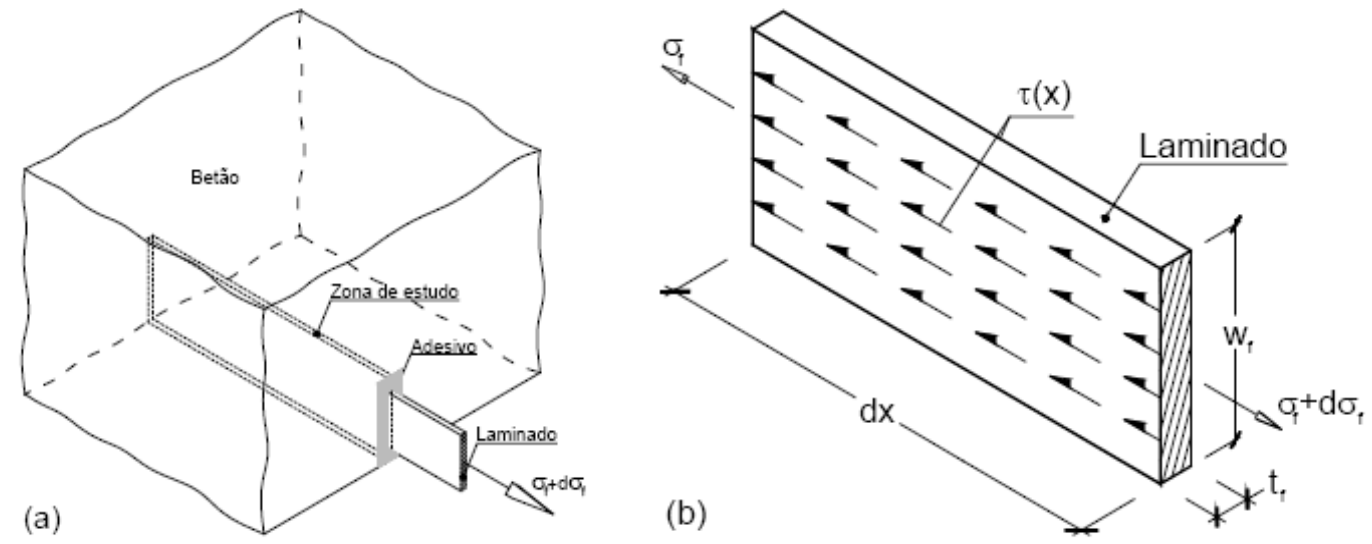

Fig. 1 - (a) Zona de estudo; (b) Condições de equilíbrio do laminado.

Figura 2.24 - Condição de equilíbrio do modelo analítico proposto (Adaptado de CRUZ; BARROS, 2003, p. 589)

Desenvolvendo a Equação 2.8 com algumas suposições apresentadas no trabalho, é possível determinar o comprimento de ancoragem, a distância entre entalhes e a largura dos entalhes.

Os autores compararam o resultado experimental com o método teórico proposto e o resultado pode ser visto na Figura 2.25. Os diagramas são referentes à força $x$ deslizamento no início e no final da zona de ancoragem: 

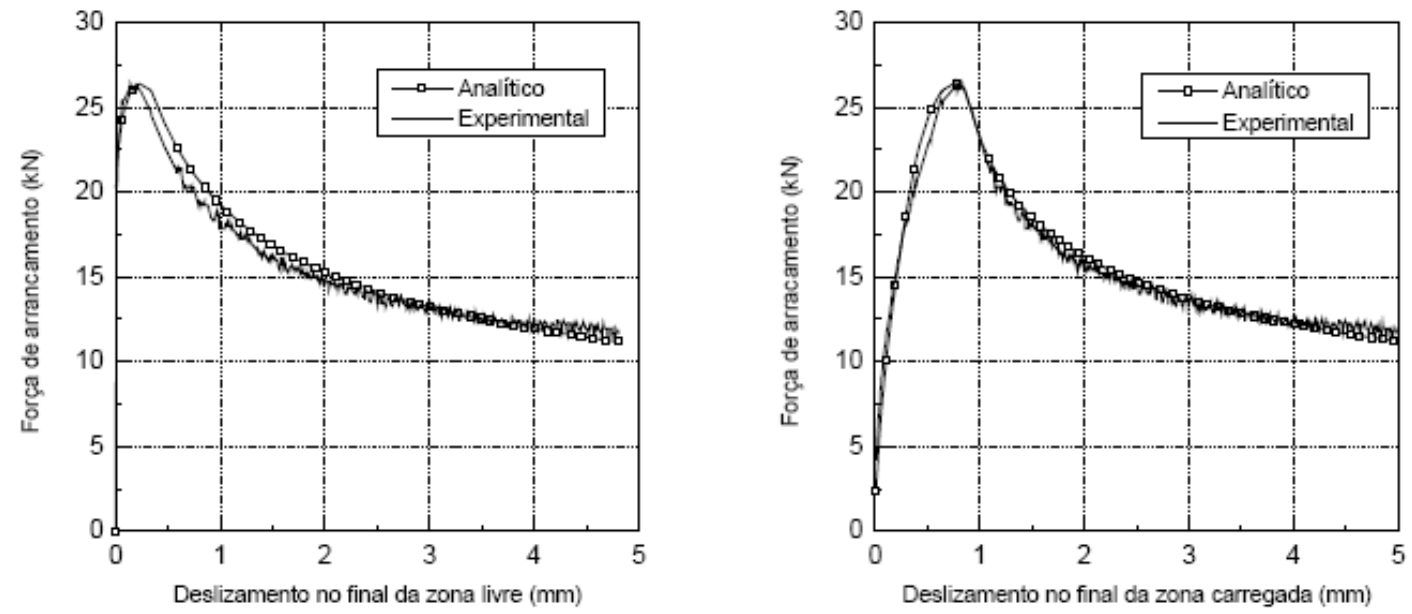

Figura 2.25 - Comparação entre resultados obtidos pelos métodos analítico e experimental (Adaptado de CRUZ; BARROS ,2003, p. 595)

Observa-se uma boa concordância entre os resultados, validando o método proposto pelos autores.

Outro modelo analítico foi proposto por Hassan e Rizkalla (2002) para investigar a transferência de tensão do laminado ao concreto. Ele foi baseado na transferência do esforço cisalhante de laminados colados externamente, com a modificação que contempla a dupla área de aderência (Figura 2.26). O modelo também contou com a redução da rigidez à flexão devido à fissuração do concreto.

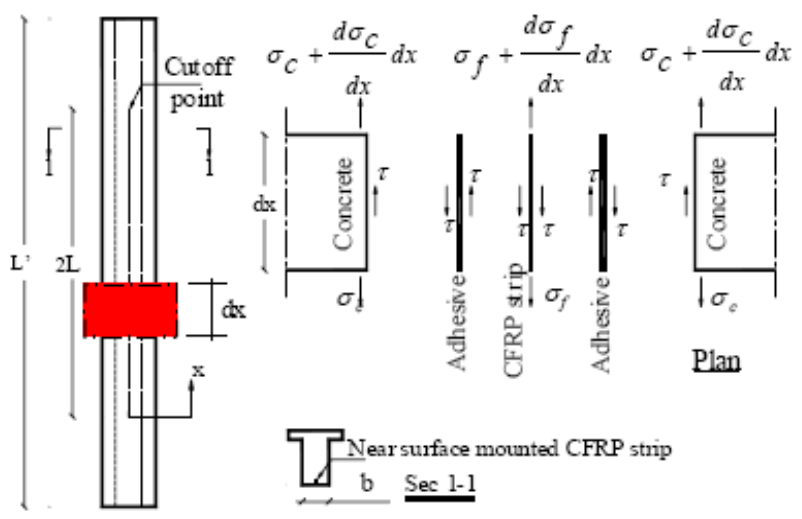

Figura 2.26 - Modelo analítico proposto, contemplando dupla área de aderência (Adaptado de HASSAN; RIZKALLA, 2002, p. 7)

Para viga simplesmente apoiada, com uma carga concentrada aplicada no meio do vão, a tensão de cisalhamento máxima foi expressa pelas seguintes equações: 


$$
\begin{gathered}
\tau=\frac{t_{f}}{2} \cdot\left\lceil\frac{n \cdot P \cdot l_{o} \cdot y}{2 \cdot I_{e f f}} \cdot \omega+\frac{n \cdot P \cdot y}{2 \cdot I_{e f f}}\right\rceil \\
\omega^{2}=\frac{2 \cdot G_{a}}{t_{a} \cdot t_{f} \cdot E_{f}} \\
n=\frac{E_{f}}{E_{c}}
\end{gathered}
$$

onde:

$E_{f}=$ módulo de elasticidade do laminado;

$E_{c}=$ módulo de elasticidade do concreto;

$G_{a}=$ módulo de cisalhamento do adesivo;

$t_{a}=$ largura do laminado;

$l_{o}=$ comprimento de ancoragem;

$Y=$ distância entre o laminado e a linha neutra da seção reforçada, e

$I_{e f f}=$ momento de inércia da seção reforçada.

A ruptura da aderência ocorre quando a tensão de cisalhamento atinge um valor máximo que depende exclusivamente das propriedades do concreto. Essa tensão crítica de cisalhamento do concreto pode ser retirada do círculo de Mohr-Coulomb e ser expressa por:

$$
\tau_{\max }=\frac{f^{\prime}{ }_{c} \cdot f_{c t}}{f^{\prime}{ }_{c}+f_{c t}}
$$

onde: $f_{c}^{\prime}$ é a resistência à compressão do concreto aos 28 dias e $f_{c t}$ é a resistência à tração do concreto.

Ou seja, a resistência máxima de cisalhamento do reforço depende exclusivamente da resistência do concreto, retomando o assunto da importância dessa característica. Os autores 
explicam que os outros componentes do reforço, como o adesivo e o laminado, têm resistências superiores às do concreto, assim como melhores propriedades de aderência. Para eles a eficiência do reforço depende altamente, além das propriedades do concreto, das dimensões do laminado, das propriedades do adesivo, da taxa interna de armação, do tipo de carga e das dimensões do entalhe.

A Figura 2.27 apresenta a curva obtida através das Equações 2.9 e 2.12, e pode ser utilizada para estimar o comprimento de ancoragem.

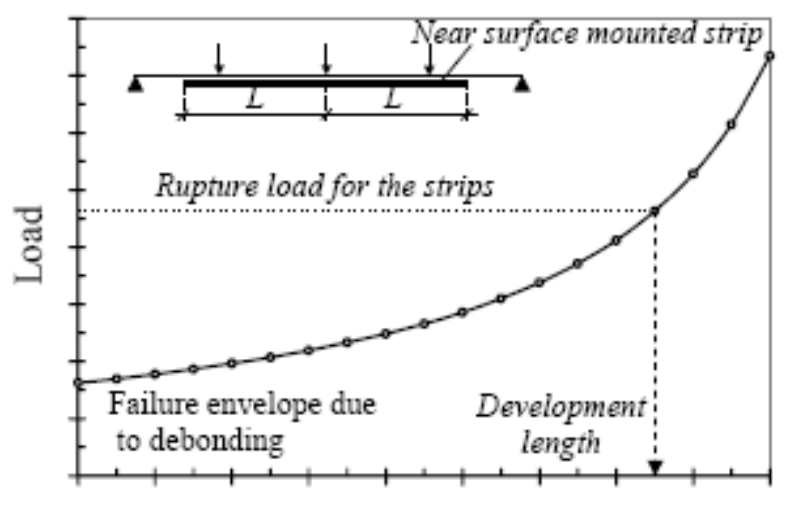

Embedment length

Figura 2.27 - Gráfico para determinação do comprimento de ancoragem (Adaptado de HASSAN; RITZKALLA, 2002, p. 9)

Em comparação com resultados experimentais, os valores encontrados através do modelo subestimaram as cargas em menos de $6 \%$.

Com relação à geometria dos elementos de reforço, De Lorenzis e Teng (2007) explicam que é menos provável ocorrer o destacamento do cobrimento de concreto quando o reforço é realizado com laminado de PRFC em comparação com as barras do mesmo material. As tensões de tração presentes no reforço são transmitidas ao adesivo epoxídico de maneira radial, que por sua vez transmitem ao concreto. Dependendo da capacidade do adesivo e do tamanho do entalhe, a ruptura pode dar-se nessa região. Todavia, como a capacidade do adesivo, em geral, é maior que a capacidade do concreto, quando a resistência à tração do concreto é excedida, ocorre a formação de fissuras cisalhantes em planos inclinados em relação ao eixo do reforço. No caso dos laminados, essas tensões instaladas no reforço são transmitidas apenas através de suas faces laterais, ao contrário das barras, que, devido a sua geometria, formam um plano de destacamento do cobrimento de concreto (Figura 2.28). 


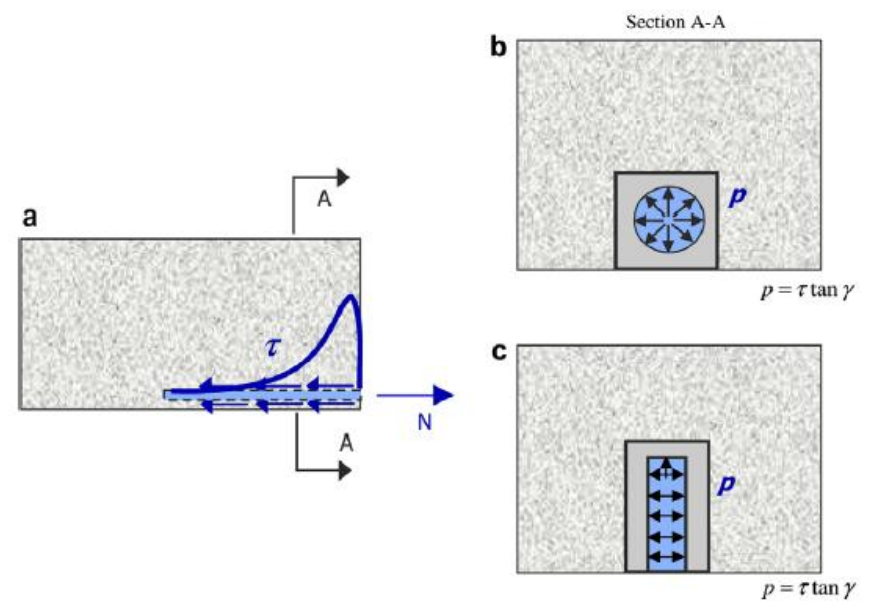

Figura 2.28 - Distribuição das tensões de tração em barras e laminados de PRFC (Adaptado de DE LORENZIS; TENG, 2007, p. 128)

Caso o fenômeno ocorra, segundo os autores, dar-se-á da seguinte maneira (Figura 2.29):

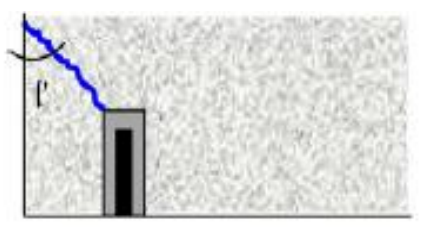

SP-ED: Fracture of the concrete edge

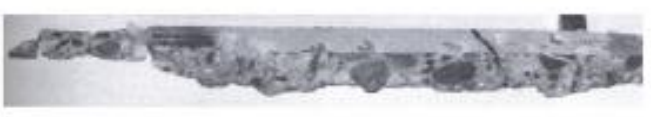

Figura 2.29 - Formação de fissuras cisalhantes na região do reforço (Adaptado de DE LORENZIS; TENG, 2007, p. 127)

Outro aspecto importante a ser considerado é a situação da estrutura existente antes de ser reforçada. Segundo Juvandes (1999), aspectos iniciais da estrutura podem condicionar o sistema de reforço. Concretos de baixa resistência e em más condições, armaduras internas corroídas e fissuras na superfície do concreto são passíveis de serem encontrados. Ocorrendo tal situação, é fundamental reparar o substrato antes de receber o reforço.

Em seu trabalho, o autor estudou algumas formas de preparação da base do substrato para receber o laminado colado externamente em vigas novas e em vigas com oito anos de idade. Foram criadas três séries de ensaios: A e B com vigas novas e a série $\mathrm{C}$ formada por vigas com oito anos, que apresentavam sinais de degradação. Essa última série foi subdivida em dois grupos para analisar a influência do envelhecimento do adesivo epóxi. Uma dessas sub-séries foi ensaiada um ano após o reforço. 
Concluiu-se que o grau de deterioração de uma viga, pode alterar as propriedades mecânicas da interface de aderência, sobretudo pela baixa resistência do concreto. A série C teve aumento de apenas $41 \%$ sobre a capacidade de carga das vigas. Com relação ao envelhecimento do adesivo, observou-se que um ano de cura trouxe aumento significativo à capacidade de carga da viga (até $63 \%$ ), sem repercussão negativa da deterioração do concreto.

Em ensaios de "pull-off” realizados nas vigas da série $\mathrm{C}$, todos apresentaram valores inferiores aos de norma, variando entre 0,7 e 1,1 MPa. Os valores mínimos de aderência a serem encontrados em ensaios de arrancamento por tração (“pull-off”) são de 1,4 MPa para o ACI 440F e de 1,5 MPa para o CEB.

A preparação da superfície de concreto e o tipo de adesivo utilizado no reforço também tiveram grande influência sobre os resultados. Antes de aplicar a resina (Sikadur ${ }^{\circledR} 30$ ) em uma das vigas da série B, espalhou-se outra resina (Sikadur ${ }^{\circledR} 31$ ) funcionando como primário. $\mathrm{O}$ resultado foi que a distribuição de tensões ao longo do laminado foi mais regular em comparação aos outros modelos e o destacamento do laminado deu-se por ruína interlaminar em toda a extensão. Em geral, o modo de falha das demais vigas dessa série deuse por destacamento antecipado do laminado de maneira frágil.

Experiência semelhante foi adquirida por Barros e Antunes (2004) que realizaram reforços com laminados inseridos em pisos de edifícios industriais. No dimensionamento do reforço, foram consideradas duas situações: a primeira na qual as fissuras existentes eram preenchidas e a segunda, onde não eram. O momento resistente de cálculo só foi superado nos casos onde as fissuras existentes foram preenchidas antes da aplicação do reforço.

\subsubsection{Resinas}

As propriedades da resina são fundamentais para garantir a integridade do conjunto laminado-resina-concreto, compondo assim o reforço. É ela quem transmite a força de tração mobilizada pelo laminado para o concreto adjacente. Juvandes (1999, p. 2.60) explica que

[...] um adesivo deve ajustar-se às circunstâncias que envolvem cada caso prático de reforço, através da seleção de um material com resistência à tração e ao cisalhamento superiores ao da camada de base e capaz de diminuir as hipóteses de uma ruptura frágil.

As características mais relevantes da resina são as resistências à tração e ao cisalhamento, a capacidade de aderência e a consistência. Reforço em regiões de momentos 
negativos permite o uso de um material mais fluido. Nos outros casos, é necessário um material com alta viscosidade para evitar gotejamento, gerando dificuldade na trabalhabilidade, além da falta de garantia de que o laminado aderiu ao concreto. Tal problema foi relatado no trabalho de Fonseca (2007) no qual, mesmo utilizando a resina indicada pelo fabricante, houve dificuldade na aplicação do produto. A Figura 2.30 mostra a configuração do ensaio realizado no trabalho citado:

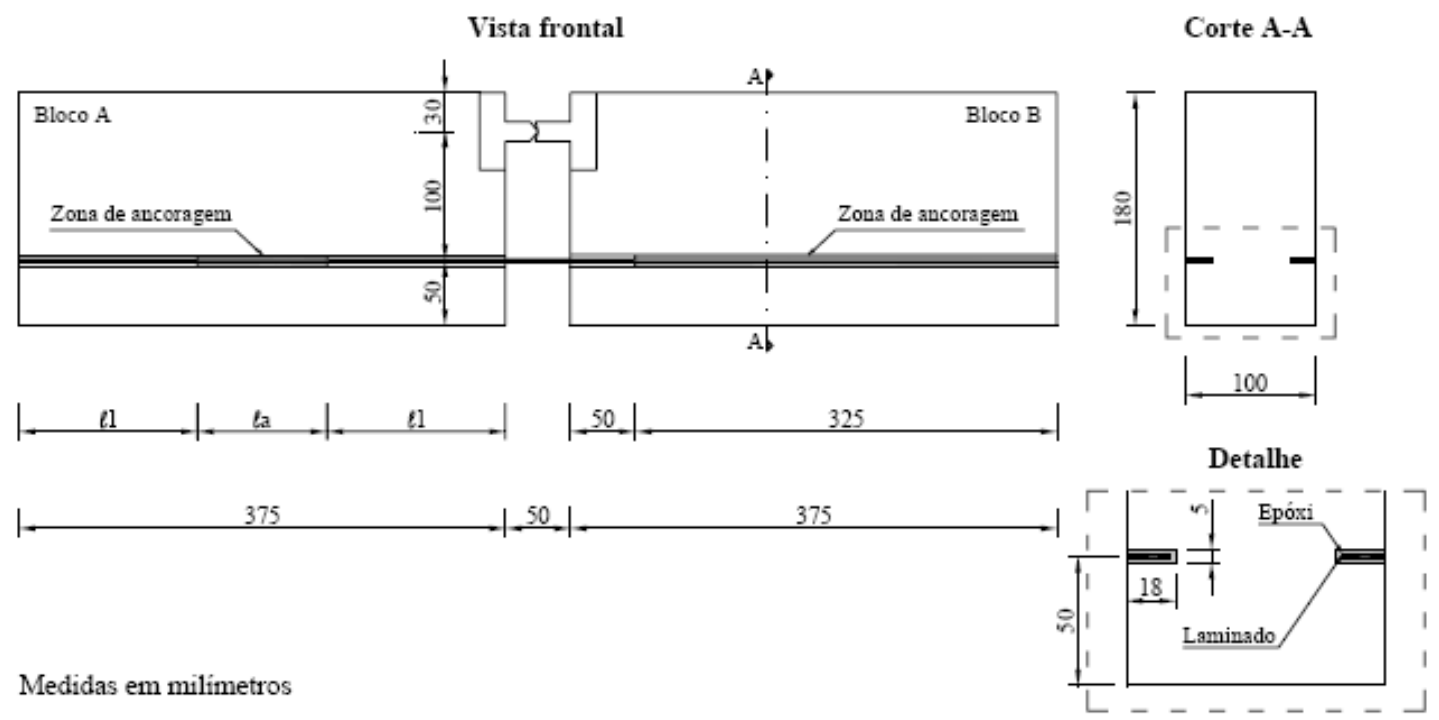

Figura 2.30 - Configuração do ensaio (Adaptado de FONSECA, 2007, p. 87)

Para delimitar a área de ancoragem e conseguir que a resina não espalhasse além do necessário, foram utilizadas fitas adesivas. Mesmo com o cuidado de confinar o adesivo, observou-se um mau acabamento do elemento, além da apresentação de vazios. Isso gerou resultados inferiores aos esperados, com ruptura por deslizamento na interface entre o adesivo e o concreto. Refazendo os ensaios com produto de outra marca (Sikadur $330^{\circledR}$ ), obteve-se melhor aproveitamento do reforço, como observado nos gráficos da Figura 2.31: 


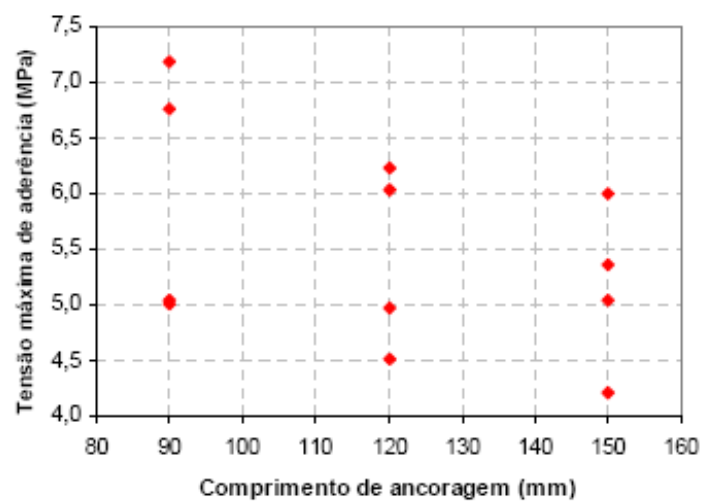

(a)

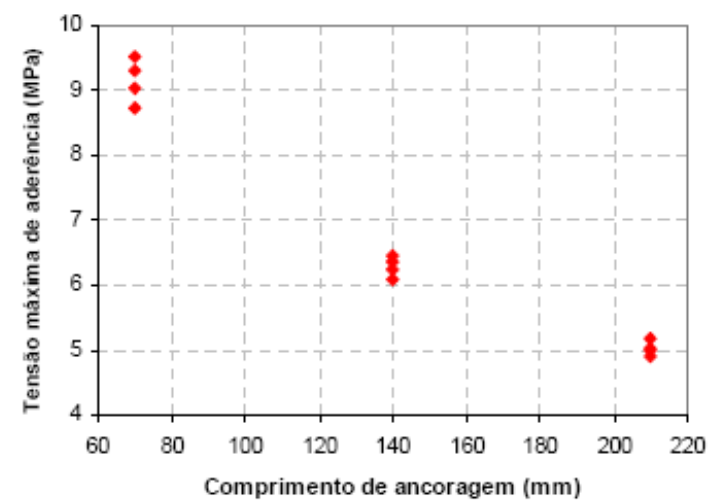

(b)

Figura 2.31 - Variação da tensão de aderência com o comprimento de ancoragem: (a) resina que apresentou problema; (b) resina Sikadur 330®. (Adaptado de FONSECA, 2007, p. 105)

De Lorenzis e Teng (2007) falam da possibilidade de misturar areia à resina epóxi como forma de aumentar o volume, controlar a viscosidade, diminuir o coeficiente de dilatação térmica e elevar a temperatura de transição vítrea. Em contrapartida, alertam para a redução da aderência quando se utilizam barras de superfície lisa.

Oliveira Junior (2005) teve problemas semelhantes de consistência. Após perceber que a resina não endurecia mesmo depois de duas semanas, enquanto o tempo indicado na ficha técnica era de uma hora e meia, o autor entrou em contato com o fabricante. As informações eram de que a dosagem 1:1 da resina poderia ser tanto em peso quanto em volume. Pequenos corpos de prova foram confeccionados com as duas formas de dosagem e observou-se que a informação não era verídica. Os corpos de prova dosados em volume tiveram endurecimento mais rápido e sem formação de bolhas como observado nos corpos de prova dosados em peso, que no mesmo período de tempo ainda tinha a superfície pegajosa. Como esse problema só foi detectado após o reforço de suas vigas, das três técnicas utilizadas (barra de PRFC, barra de aço e manta de fibra de carbono), apenas no caso das mantas coladas externamente não houve deslizamento, o que impossibilitou uma melhor análise dos demais reforços.

Castro (2005) relata problemas de aderência de barras de PRFC inseridas em entalhes, que produziram deslizamento no decorrer dos ensaios. Na série em que trabalhou com essas barras, não houve ruptura do reforço, mesmo após outras tentativas com diversos métodos de fixação, inclusive com cimento expandido. Deixando a sensação de que o problema possa estar na propriedade de aderência da barra. 


\subsection{Dimensionamento}

Como comentado na seção 2.7, o Brasil e muitos outros países ainda não apresentam normas específicas para reforço de estruturas utilizando a técnica NSM. Por isso, para dimensionar esse tipo de reforço é necessário adaptar algumas normas vigentes, como por exemplo, a de dimensionamento de concreto armado convencional e a de dimensionamento de concreto reforçado com barras de PRF (ACI 440.1R-03).

Longe de ser a condição ideal, esse tipo de procedimento deve ser acompanhado de fatores de segurança que absorvam as considerações realizadas, ocasionando gastos desnecessários. Soares e Martins (2006) comentam que muitos projetistas e pesquisadores limitam a capacidade máxima de tração dos compósitos entre $50 \%$ e $60 \%$, até mesmo porque não se conhece o efeito de fluência do material ao longo do tempo.

No projeto de reforço continuam válidas as hipóteses básicas indicadas nas normas de dimensionamento de concreto armado convencional, como a ABNT NBR 6118 (2003):

- as seções transversais consideradas planas antes da deformação provocada pelo momento fletor permanecem planas após a deformação;

- a deformação das barras passivas (nesse caso, também dos laminados) submetidas à tração ou à compressão é a mesma do concreto em seu entorno;

- as tensões de tração no concreto, normais à seção transversal, podem ser desprezadas;

- a distribuição de tensões no concreto se faz de acordo com o diagrama parábolaretângulo, com tensão igual a $0,85 f_{c d}$.

O ACI 440.1R-03 acrescenta apenas que o comportamento à tração do reforço de PRF é linearmente elástico até a ruptura.

Soares e Martins (2006) explicam que assumindo essas hipóteses e considerando o estado inicial de tensão e deformação do elemento no ato do reforço, além das leis constitutivas dos materiais e dos critérios de cedência, é possível prever o comportamento de uma estrutura reforçada.

Para esses autores, deve haver um limite máximo de reforço objetivando a segurança da estrutura. Por isso, recomendam que o excedente de carga, à qual a estrutura deve ser reforçada, não ultrapasse $50 \%$ da capacidade de carga da estrutura existente. Além disso, caso 
haja rompimento do reforço, a estrutura original deve ter resistência suficiente para suportar a carga inicial e evitar o colapso geral.

Para dimensionamento à flexão no estado limite último, o modo de ruína desejável ocorre pela ruptura do reforço ou esmagamento do concreto, sendo a ocorrência dos dois simultaneamente a condição ideal. O ACI 440.1R-03 dimensiona a estrutura pelos estados limites último e de serviço. Em muitos casos, critérios de manutenção, fadiga e limites de resistência de ruptura, controlam a capacidade de reforço do elemento.

A norma relata a diferença de comportamento entre a viga reforçada com barras de aço e reforçada com barras de PRF. No primeiro caso, a plastificação do aço permite a alta deformação da viga, que funciona como um alerta. Já no segundo caso, a falta de ductilidade exige uma reconsideração no dimensionamento, já que sem aviso, ocorre a ruptura do reforço e o súbito colapso. Para compensar esse problema, o elemento reforçado deverá ter uma maior reserva de capacidade de carga. Ou seja, os coeficientes de segurança de estruturas reforçadas com PRF devem ser maiores que àqueles do concreto armado convencional.

O uso de concreto de alta resistência pode proporcionar melhor aproveitamento das barras de PRF e maior resistência da peça fissurada. Em contrapartida, torna a estutrura ainda mais rígida.

Dependendo das condições ambientais às quais o reforço está inserido, utiliza-se um fator de segurança para compensar eventuais perdas de capacidade de carga, resistência à fadiga e capacidade de deformação do material. Para polímeros reforçados com fibra de carbono, esse coeficiente é igual a 1, no caso de estruturas protegidas de intempéries e sem contato com o solo, e 0,9 caso contrário. Esse valor já contempla variações de temperatura, desde que não exceda a temperatura vítrea da resina. O módulo de elasticidade não sofre alteração.

A tensão de cálculo é obtida através da Equação 2.13:

$$
f_{f u}=C_{E} x f_{f u}^{*}
$$

onde:

$f_{f u}=$ resistência à tração de cálculo de uma barra de PRF; 
$C_{E}=$ fator de redução;

$f_{f u}^{*}=$ resistência à tração de uma barra de PRF definida como a força média de tração de uma amostragem menos três vezes o desvio padrão $\left(f_{f u}^{*}=f_{u, a v e}-3 \sigma\right)$.

A deformação máxima é encontrada de maneira análoga (Equação 2.14):

$$
\varepsilon_{f u}=C_{E} x \varepsilon_{f u}^{*}
$$

A recomendação do ACI 440.1R-03 é para o dimensionamento à flexão de vigas de seção retangular com uma única camada de um único tipo de reforço de PRF. Porém, os conceitos propostos podem ser utilizados para dimensionamento utilizando diferentes formas em múltiplas camadas do material. Embora não haja evidência de que a teoria não se aplica a vigas com seções diferentes da retangular, o comportamento ainda não confirmado por ensaios experimentais.

A capacidade de carga da viga reforçada depende de onde ocorre a falha: no concreto, no reforço ou em ambos. O modo de falha pode ser determinado comparando a taxa de armadura de PRF (Equação 2.15) com a taxa de armadura equivalente (Equação 2.16), situação na qual ocorre simultaneamente o esmagamento do concreto e a ruptura do reforço.

$$
\begin{gathered}
\rho_{f}=\frac{A_{f}}{b \cdot d} \\
\rho_{f b}=0,85 \cdot \beta_{1} \cdot \frac{f_{c}^{\prime}}{f_{f u}} \cdot \frac{E_{f} \cdot \varepsilon_{c u}}{E_{f} \cdot \varepsilon_{c u}+f_{f u}}
\end{gathered}
$$

onde:

$A_{f}=$ área de reforço de PRF $\left(\right.$ in $\left.^{2}\right)$;

$d=$ distância do centro de gravidade de PRF à fibra mais comprimida do concreto (in);

$b=$ largura da seção transversal da viga (in); 
$f^{\prime}{ }_{c}=$ resistência do concreto $(\mathrm{psi})$;

$f_{f u}=$ resistência de cálculo do PRF (psi);

$E_{f}=$ módulo de elasticidade do PRF, definido como módulo médio de uma amostra de corpos de prova (psi);

$\varepsilon_{c u}=$ deformação última do concreto.

Se a taxa de armadura $\left(\rho_{f}\right)$ for inferior à taxa equivalente $\left(\rho_{f b}\right)$, o colapso é regido pela ruptura do reforço, caso contrário ocorre o esmagamento do concreto. Geralmente a taxa equivalente de estruturas reforçadas com PRF é menor que a encontrada para estuturas reforçadas com aço.

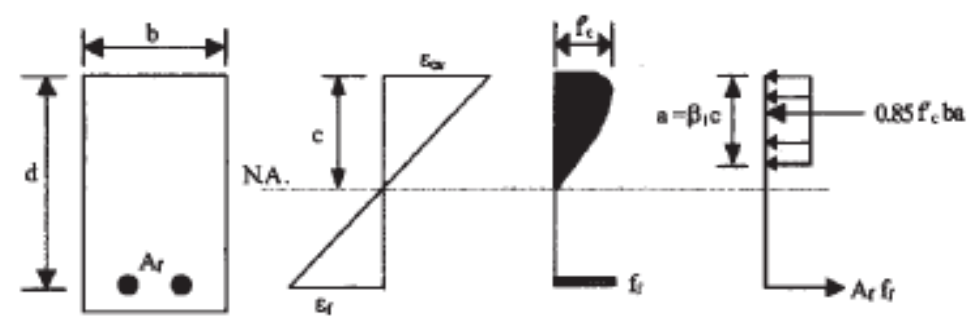

(a) Failure governed by concrete crushing

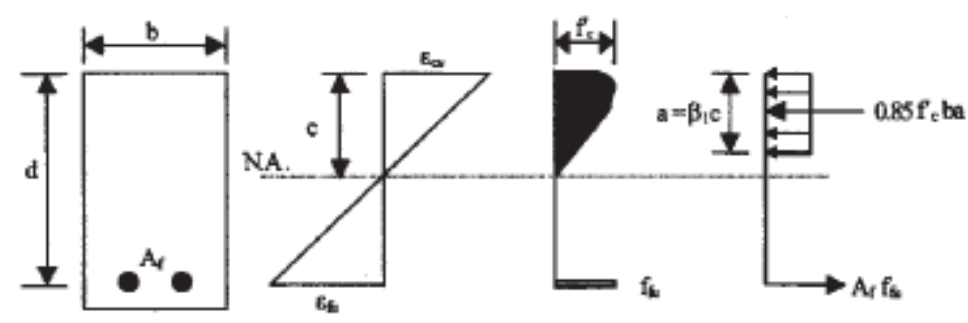

(b) Balanced failure condition

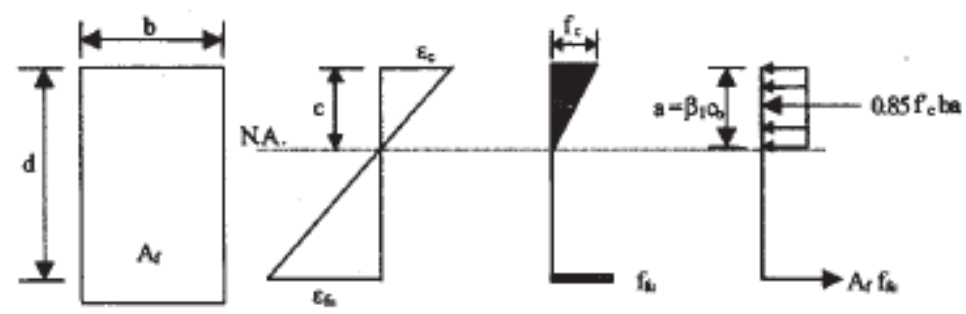

(c) Failure governed by FRP rupture (concrete stress may be nonlinear)

Figura 2.32 - Tensões e deformações no estado limite último (Adaptado de ACI 440.1R, 2003, p.18) 
Quando $\rho_{f}>1,4 . \rho_{f b}$ o colapso é iniciado pelo esmagamento do concreto e o momento resistente da seção pode ser calculado através das Equações 2.17 à 2.19:

$$
\begin{gathered}
M_{n}=A_{f} \cdot f_{f} \cdot\left(d-\frac{a}{2}\right) \\
a=\frac{A_{f} \cdot f_{f}}{0,85 \cdot f_{c}^{\prime} \cdot b} \\
f_{f}=E_{f} \cdot \varepsilon_{c u} \cdot \frac{\beta_{1} \cdot d-a}{a}
\end{gathered}
$$

onde:

$M_{n}=$ momento resistente (lb.in);

$A_{f}=$ área de reforço de PRF $\left(\right.$ in $\left.^{2}\right)$;

$f_{f}=$ resistência do PRF (psi);

$d=$ distância do centro de gravidade de PRF à fibra mais comprimida do concreto (in);

$a$ = distância do centro do retângulo equivalente de tensões à fibra mais comprimida do concreto (in);

$b=$ largura da seção transversal da viga (in);

$f_{c}^{\prime}=$ resistência do concreto $(\mathrm{psi})$;

$E_{f}=$ módulo de elasticidade do PRF, definido como módulo médio de uma amostra de corpos de prova (psi);

$\varepsilon_{c u}=$ deformação última do concreto.

Quando $\rho_{f}<\rho_{f b}$ o colapso ocorre pela ruptura do reforço e o momento resistente pode ser calculado através das Equações 2.20 à 2.21 


$$
\begin{gathered}
M_{n}=0,8 \cdot A_{f} \cdot f_{f u} \cdot\left(d-\frac{\beta_{1} c_{b}}{2}\right) \\
c_{b}=\left(\frac{\varepsilon_{c u}}{\varepsilon_{c u}+\varepsilon_{f u}}\right) \cdot d
\end{gathered}
$$

onde:

$f_{f u}=$ resistência à tração de cálculo de uma barra de PRF (psi);

$c_{b}=$ distância da fibra de concreto mais comprimida à linha neutra na condição de tensão equilibrada (in);

$\varepsilon_{f u}=$ deformação de cálculo do PRF.

O coeficiente de segurança também é diferente para os dois modos de ruptura. Quando a ruptura se der pelo esmagamento do concreto, o fator é igual à 0,70 assim como ocorre nas estruturas reforçadas com aço. Quando ocorrer por ruptura do reforço, o valor passa a ser 0,50 por apresentar menor ductilidade.

Enquanto o esmagamento do concreto pode ser previsto com base no cálculos, a viga reforçada pode não falhar em conformidade. Por exemplo, se a resistência do concreto for maior que a especificada, pode haver ruptura do reforço. Por essa razão, e para estabelecer uma transição entre os dois valores de $\Phi$, a Equação 2.22 fornece uma transição linear entre os limites:

$$
\Phi=\left\{\begin{array}{c}
0,50 \text { para } \rho_{f} \leq \rho_{f b} \\
\frac{\rho_{f}}{2 \cdot \rho_{f b}} \operatorname{para} \rho_{f b}<\rho_{f}<1,4 \rho_{f b} \\
0,70 \text { para } \rho_{f} \geq 1,4 \rho_{f b}
\end{array}\right.
$$

Com relação à abertura de fissuras, o ACI 440.1R-03 é bastante flexível. Como os PRF não são corrosivos, as aberturas das fissuras apresentam carater mais estético que funcional, desde que não estejam associados à barras de aço. Os limites são 0,3 mm para exposição interna e 0,4 mm para exposição externa. Caso o ambiente seja agressivo, maiores 
cuidados devem ser previstos. Por outro lado, se as estruturas apresentarem vida curta, onde a estética não é uma preocupação, os requisitos de abertura de fissura podem ser desprezados. 

Muitas vezes, estruturas a serem reforçadas devem passar por um processo de reparo antes de receberem os materiais de reforço. É possível se deparar com estruturas sem condições de uso e com quadro patológico bastante avançado, como ilustra a Figura 3.1. Concreto de má qualidade, baixa resistência e deteriorado, por exemplo, deve ser substituído para garantir a integridade e o aproveitamento do reforço. Do mesmo modo, as condições das armaduras existentes devem ser observadas e analisadas, tomando-se as devidas providências, caso necessário.

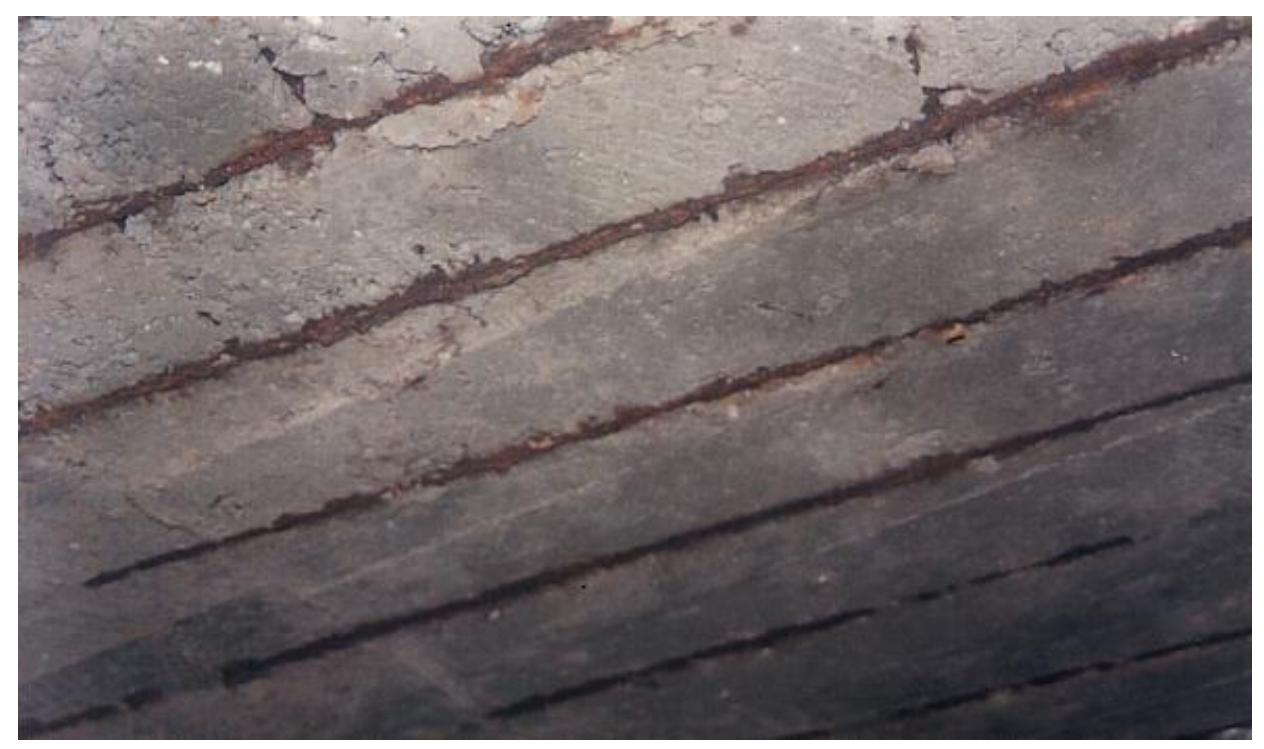

Figura 3.1 - Laje com quadro patológico avançado

Associado a esse fato, tem-se a característica natural da baixa resistência à tração do concreto, mesmo que em boas condições. O valor, que fica em torno de $10 \%$ da resistência à compressão é, inclusive, desprezado no dimensionamento à flexão de estruturas de concreto armado.

No caso de reforço à flexão de vigas e lajes, sobretudo a momentos positivos, a junção desses dois fatores (patologia e baixa resistência) pode limitar o incremento de resistência fornecido ao elemento através do reforço. Para reforço a momentos negativos, geralmente as estruturas encontram-se mais protegidas de ataques físicos e químicos por terem a seu favor a regularização e o acabamento dos pisos. 
Admitindo que o laminado de polímero reforçado com fibra de carbono (PRFC) é mais resistente à tração que o aço e deverá estar aderido ao concreto, que apresenta menor resistência a essa solicitação, fica evidente que existente uma certa incompatibilidade no sistema de reforço.

Pensando nisso, Ferrari (2007), que estudou reforço de vigas à flexão utilizando manta de PRFC, propôs a substituição do concreto situado na parte tracionada da viga por um compósito que respondesse melhor à solicitação. $\mathrm{O}$ objetivo foi produzir um material que controlasse a fissuração do concreto e retardasse o desprendimento prematuro da manta.

Uma maneira de atender a essas exigências foi inserir fibras de aço no concreto, de modo a obter um material mais dúctil, com consequente controle da abertura das fissuras. Porém, as fibras de aço só apresentam resposta significativa na fase pós-pico de carga, o que permite que microfissuras se formem na matriz cimentícia com cargas inferiores à máxima. Para esse fato, foi desenvolvida uma microfibra de aço, ainda não encontrada comercialmente, com o intuito de atenuar o processo de microfissuração e melhorar a transferência de tensões da matriz para as fibras na fase pré-pico de carga, através do aumento da aderência.

Para receber as fibras, o Ferrari (2007) analisou duas matrizes diferentes, uma de concreto e outra de argamassa. Na busca pelos melhores resultados, vinte compósitos diferentes foram analisados, variando-se as proporções de fibras e microfibras incorporadas às matrizes. Por ter uma aplicação específica e buscar uma elevação no nível de desempenho estrutural, Ferrari (2007) chamou o material de compósito cimentício de alto desempenho (CCAD). Para facilitar o estudo, decidiu-se manter nesse trabalho, as mesmas nomenclaturas utilizadas por ele.

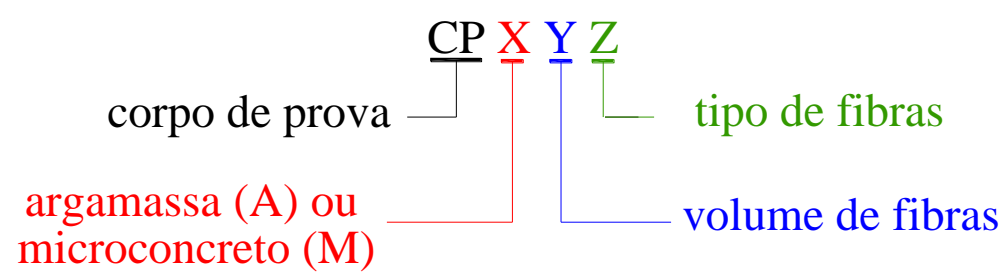

Figura 3.2 - Nomenclatura dos compósitos cimentícios de alto desempenho (Adaptado de FERRARI, 2007, p.133) 
Capítulo 3 - Desenvolvimento do Compósito

Os compósitos analisados estão apresentados na Tabela 3.1:

Tabela 3.1 - Compósitos analisados (FERRARI, 2007, p.135)

\begin{tabular}{|c|c|c|c|c|}
\hline Material & Grupo & Compósitos & Taxa de fibra & Tipo de fibra \\
\hline \multirow{15}{*}{ 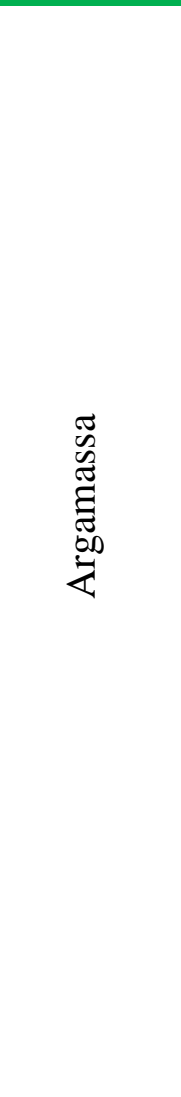 } & 1 & $\mathrm{CPA}$ & $0 \%$ & - \\
\hline & 2 & CPA1A & $1 \%$ & A \\
\hline & 3 & CPA1.5A & $1.5 \%$ & $\mathrm{~A}$ \\
\hline & 4 & CPA2A & $2 \%$ & $\mathrm{~A}$ \\
\hline & 5 & CPA1B & $1 \%$ & $\mathrm{~B}$ \\
\hline & 6 & CPA1.5B & $1.5 \%$ & B \\
\hline & 7 & CPA2B & $2 \%$ & $\mathrm{~B}$ \\
\hline & 8 & CPA2.5B & $2.5 \%$ & B \\
\hline & 9 & CPA0.5A1.5B & $0.5 \%+1.5 \%$ & $A+B$ \\
\hline & 10 & CPA1A1B & $1 \%+1 \%$ & $A+B$ \\
\hline & 11 & CPA1.5A0.5B & $1.5 \%+0.5 \%$ & $A+B$ \\
\hline & 12 & CPA1.5A0.5C & $1.5 \%+0.5 \%$ & $A+C$ \\
\hline & 13 & CPA1.5A1.5C & $1.5 \%+1.5 \%$ & $A+C$ \\
\hline & 14 & CPA1.5A2.5C & $1.5 \%+1.5 \%$ & $A+C$ \\
\hline & 15 & CPA1.5A3.5C & $1.5 \%+3.5 \%$ & $A+C$ \\
\hline \multirow{5}{*}{$\begin{array}{l}\stackrel{0}{0} \\
0 \\
0 \\
0 \\
0 \\
0 \\
0 \\
:\end{array}$} & 16 & $\mathrm{CPM}$ & $0 \%$ & - \\
\hline & 17 & CPM1A & $1 \%$ & A \\
\hline & 18 & CPM1A1C & $1 \%+1 \%$ & $A+C$ \\
\hline & 19 & CPM1A2C & $1 \%+2 \%$ & $A+C$ \\
\hline & 20 & CPM1A2.5C & $1 \%+2.5 \%$ & $A+C$ \\
\hline
\end{tabular}

*Volume de fibra em relação ao volume de concreto

As fibras tipo A, B e C são as seguintes: 
Tabela 3.2 - Características das fibras de aço utilizadas na produção dos compósitos (FERRARI, 2007, p.136)

\begin{tabular}{c|c|c|c}
\hline Parâmetros & $\begin{array}{c}\text { Fibra A: FS8 } \\
\text { WIRAND }\end{array}$ & Fibra B & Fibra C \\
\hline $\begin{array}{c}\text { Formato } \\
\text { Longitudinal }\end{array}$ & $25 \mathrm{~mm}$ & $0,60 \mathrm{~mm}$ & $0,75 \mathrm{~mm}$ \\
\hline $\begin{array}{c}\text { Diâmetro } \\
\text { nominal }\end{array}$ & $0,75 \mathrm{~mm}$ & $0,2827 \mathrm{~mm}^{2}$ & $0,4418 \mathrm{~mm}^{2}$ \\
\hline $\begin{array}{c}\text { Área da seção } \\
\text { transversal }\end{array}$ & $0,4418 \mathrm{~mm}^{2}$ & 22 & 17 \\
\hline $\begin{array}{c}\text { Fator de forma } \\
\text { Tensão máxima } \\
\text { de tração }\end{array}$ & $1100 \mathrm{MPa}$ & $1100 \mathrm{MPa}$ & $1100 \mathrm{MPa}$ \\
\hline Peso Específico & $7850 \mathrm{~kg} / \mathrm{m}^{3}$ & $7850 \mathrm{~kg} / \mathrm{m}^{3}$ & $7850 \mathrm{~kg} / \mathrm{m}^{3}$ \\
\hline
\end{tabular}

$\mathrm{Na}$ análise dos resultados, em termos de resistência ao fraturamento, o autor concluiu que o compósito de argamassa CPA1.5A1.5C apresentou desempenho compatível ao do microconcreto CPM1A2C. Mas optou-se pelo segundo, por possuir agregado graúdo, que melhora a aderência da manta ao substrato.

A configuração do ensaio final de Ferrari (2007), utilizando o CCAD na face tracionada da viga foi a seguinte (Figura 3.3):

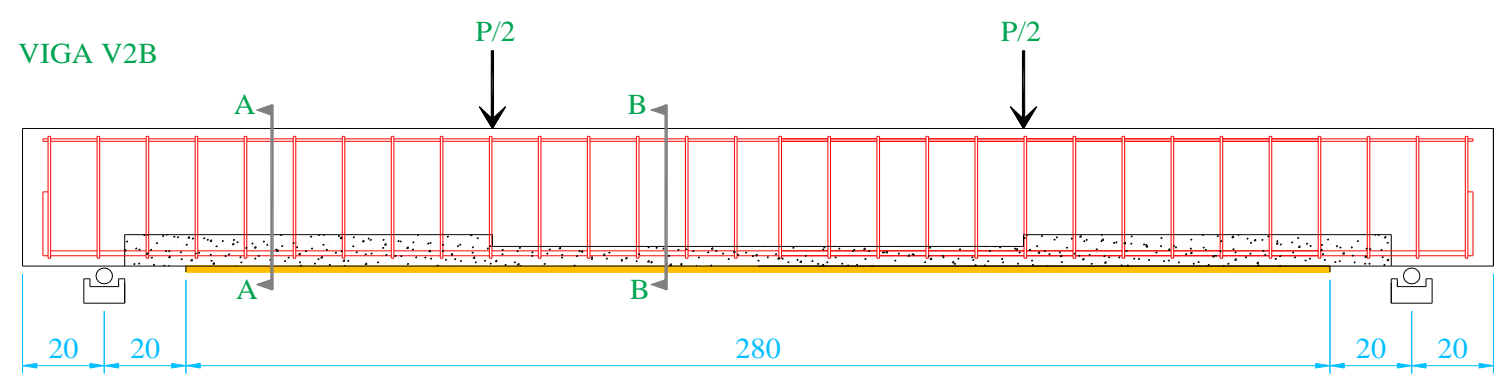



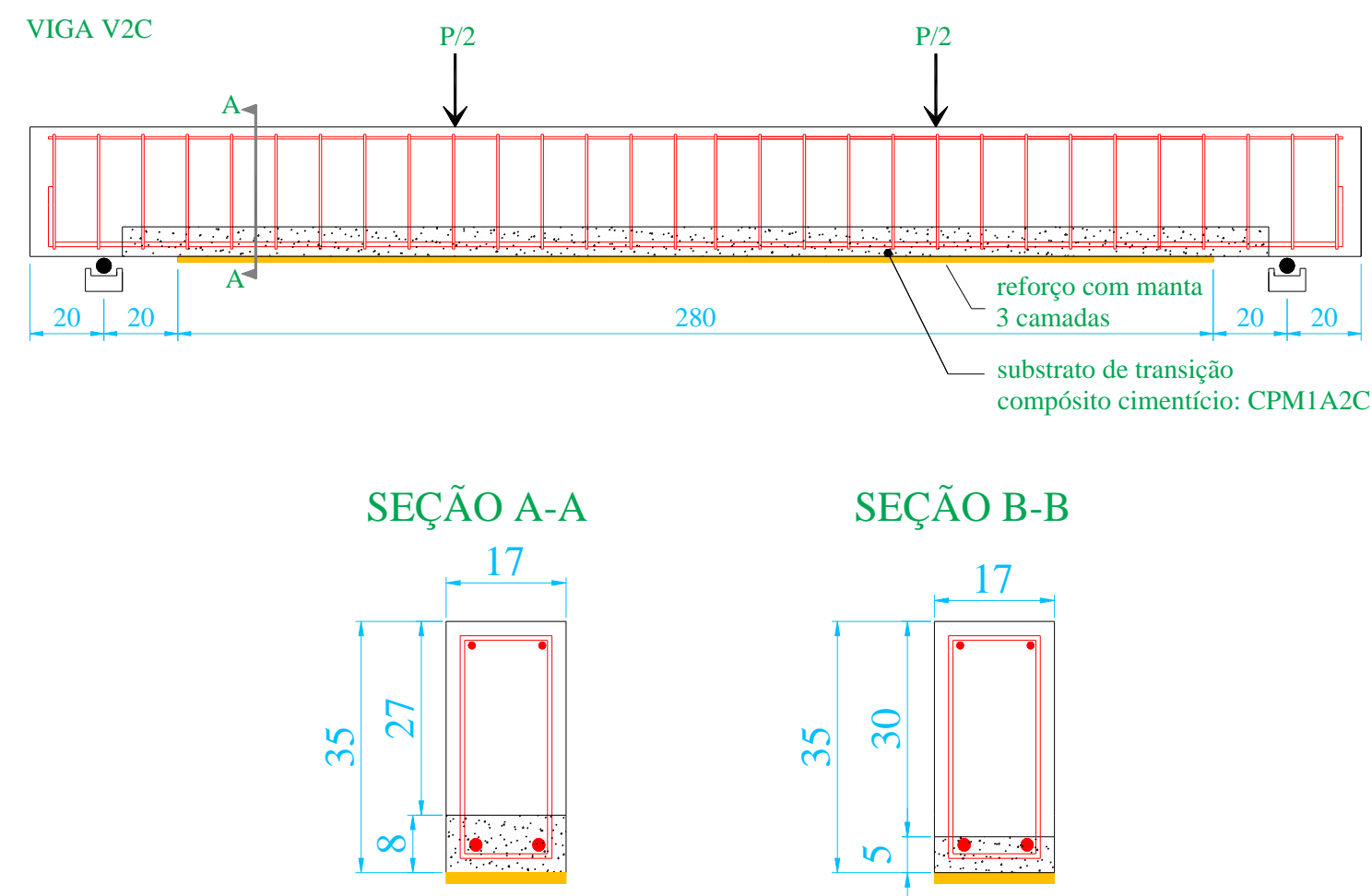

Figura 3.3 - Configuração do ensaio realizado por Ferrari (2007) com reconstituição da face tracionada da viga (Adaptado de FERRARI, 2007, p.214)

Analisando os ensaios à flexão a quatro pontos, Ferrari (2007, p.299) concluiu que

[...] a reconstituição prévia do banzo tracionado com um compósito cimentício de alto desempenho à base de macro e microfibras de aço evita a rápida propagação de fissura crítica na extremidade do reforço e retarda o desprendimento prematuro da manta. Com a presença de um material de maior resistência ao fraturamento no banzo tracionado da viga, as fissuras são mais distribuídas e de menor abertura ao longo da extensão do reforço.

O uso de fibras de aço no substrato juntamente com a aplicação da manta de PRFC proporcionou um expressivo aumento na resistência final (até 120\%) e na rigidez da viga (até 67\%) em comparação com a viga de referência.

Diante dos bons resultados e como forma de complementar o estado da arte sobre reforço com PRFC, manteve-se no presente trabalho o uso do CCAD aplicado na região tracionada da viga. No entanto, apesar dos resultados satisfatórios obtidos por Ferrari (2007), entendeu-se que nesta pesquisa os traços de concreto deveriam ser reestudados para efeito de aprendizado da autora e também com o objetivo de alcançar possíveis melhorias na capacidade de carga do reforço.

A seguir encontram-se os estudos, as análises e resultados obtidos nessa pesquisa. 


\subsection{Caracterização dos Materiais}

\subsubsection{Fibras de aço}

As fibras de aço foram adquiridas junto à empresa Maccaferri do Brasil Ltda, a mesma que forneceu o material para Ferrari (2007).

$\mathrm{Na}$ época do trabalho citado, como não existia no mercado microfibra de aço, houve um acordo entre o Departamento de Engenharia de Estruturas da EESC e a empresa para desenvolver o novo material.

A primeira proposta referiu-se à microfibra do tipo $B$, que apresentou aderência insatisfatória e os resultados em termos de ductilidade e tenacidade ao fraturamento não foram os esperados, excluindo essa configuração de fibra. Aprimorando o material, foram acrescentados ganchos nas extremidades da fibra, criando-se a microfibra do tipo C, e aí sim, os resultados foram compatíveis às expectativas. Isso motivou outros pesquisadores do laboratório a adotarem a microfibra do tipo $\mathrm{C}$ em seus trabalhos.

Quase dois anos depois, quando houve necessidade de outro lote da microfibra do tipo C para realização do presente trabalho, a empresa não aceitou reafirmar o acordo. $\mathrm{O}$ representante contactado explicou que a empresa esperava que nesse período de tempo houvesse interesse comercial na nova tecnologia, o que obviamente não ocorreu, posto que a presente pesquisa ainda não fora concluída e a divulgação dos resultados ainda incipiente. A justificativa dada foi que para produzir as microfibras, a produção das fibras comerciais deveria ser paralisada e os equipamentos, comuns para fabricação de ambas, teriam de ser reconfigurados. Como a procura por fibras convencionais havia crescido com o reaquecimento do mercado, tal paralisação seria inconveniente para a empresa.

Mesmo entendendo a posição da empresa, foi elaborado um relatório apontando os trabalhos que utilizaram a microfibra e seus respectivos resultados. Chamou-se a atenção também, para o curto espaço de tempo pelo qual a empresa esperava retorno comercial. Nesse período, apenas o trabalho de Ferrari (2007) havia sido concluído e publicado.

Assim, o material disponível para esse trabalho resumiu-se às sobras do trabalho anterior e mais cinco caixas de $20 \mathrm{~kg}$ encontradas no estoque da empresa e que foram fornecidas à pesquisa.

Em decorrência desse incidente, o fator "consumo de microfibras de aço" passou a ser um aspecto limitador. 
A fibra convencional Wirand ${ }^{\circledR}$ FS8, por ser comercial, não representou qualquer problema. Ela foi escolhida desde o trabalho de Ferrari (2007), por respeitar critérios como comprimento igual ou superior ao dobro do diâmetro do agregado e inferior a $1 / 3$ da menor dimensão do elemento estrutural.

Para facilitar a visualização do leitor a respeito dos dados das fibras utilizadas, repetem-se aqui suas informações:

Tabela 3.3 - Características das fibras de aço utilizadas no presente trabalho (Adaptado de FERRARI, 2007, p.136)

\begin{tabular}{c|c|c}
\hline Parâmetros & Fibra: Wirand ${ }^{\circledR}$ FS8 & Microfibra (tipo C) \\
\hline $\begin{array}{c}\text { Formato } \\
\text { Longitudinal }\end{array}$ & $25 \mathrm{~mm}$ & $0,75 \mathrm{~mm}$ \\
\hline $\begin{array}{c}\text { Diâmetro } \\
\text { nominal }\end{array}$ & $0,75 \mathrm{~mm}$ & $0,4418 \mathrm{~mm}^{2}$ \\
\hline $\begin{array}{c}\text { Área da seção } \\
\text { transversal }\end{array}$ & $0,4418 \mathrm{~mm}^{2}$ & 17 \\
\hline $\begin{array}{c}\text { Fator de forma } \\
\text { de tração }\end{array}$ & 33 & $1100 \mathrm{MPa}$ \\
\hline $\begin{array}{c}\text { Tensão máxima } \\
\text { Peso Específico }\end{array}$ & $7850 \mathrm{~kg} / \mathrm{m}^{3}$ & $7850 \mathrm{~kg} / \mathrm{m}^{3}$ \\
\hline
\end{tabular}

\subsubsection{Concreto}

Como se explicou anteriormente, embora os resultados de Ferrari (2007) tenham sido considerados satisfatórios, propôs-se nesse trabalho adotar um novo traço de concreto com o objetivo de aprendizado e aperfeiçoamento do compósito. Para isso, o traço do trabalho anterior foi adotado como referência inicial e alguns ajustes cabíveis foram efetuados.

O método e as considerações utilizadas para a dosagem do novo traço de concreto estão descritos no Apêndice A e o resultado final, com o objetivo de conseguir uma resistência à compressão de $50 \mathrm{MPa}$, foi o seguinte: 
Alguns quesitos práticos foram incorporados à metodologia para a preparação do concreto. O uso de aditivo superplastificante, por exemplo, tornou-se indispensável pela finalidade do concreto, que é de reconstituir viga existente, possivelmente com dimensão reduzida, congestionada por armaduras. Outro item importante foi o uso de cimento de alta resistência inicial (ARI) por possibilitar a liberação da estrutura reforçada em pouco tempo.

Com o intuito de melhorar a resistência da zona de transição (ligação entre agregados e fibras com a argamassa) foi proposta a utilização de sílica ativa. Sua principal propriedade é reduzir a porosidade do concreto através de seus mecanismos físicos e químicos, melhorando a aderência entre agregados e fibras com a argamassa (Capítulo 2). Dessa maneira, $10 \%$ do cimento foram substituídos por esse material.

Para verificar se os resultados obtidos pelo traço proposto foram os esperados, compararam-se os resultados com o traço idealizado por Ferrari (2007). Assim, foram confeccionados corpos de prova compostos pelos dois traços, com e sem adição de sílica ativa, divididos em duas séries (Tabela 3.4):

Tabela 3.4 - Traços de concreto ensaiados

\begin{tabular}{|c|c|c|c|}
\hline Séries & Origem & Traço & Sílica ativa $(10 \%)$ \\
\hline \multirow{2}{*}{$\stackrel{0}{:}$} & \multirow{2}{*}{ Ferrari (2007) } & \multirow{2}{*}{$1: 2,13: 1,83: 0,48$} & Sem sílica (SS) \\
\hline & & & Com sílica (CS) \\
\hline \multirow{2}{*}{ 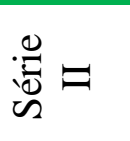 } & \multirow{2}{*}{ Novo traço } & \multirow{2}{*}{$1: 2,30: 1,70: 0,48$} & Sem sílica (SS) \\
\hline & & & Com sílica (CS) \\
\hline
\end{tabular}

Os consumos de materiais para moldagem de seis corpos de prova cilíndricos 10 x 20 cm estão apresentados na Tabela 3.5:

Tabela 3.5 - Consumo de material para modelagem dos corpos de prova

\begin{tabular}{c|c|c}
\hline Material & $\begin{array}{c}\text { Consumo } \\
\text { (Série I) }\end{array}$ & $\begin{array}{c}\text { Consumo } \\
\text { (Série II) }\end{array}$ \\
\hline Cimento CPV ARI & $5,26 \mathrm{~kg}\left(4,73 \mathrm{~kg}^{*}\right)$ & $5,21 \mathrm{~kg}\left(4,69 \mathrm{~kg}^{*}\right)$ \\
\hline Areia & $11,20 \mathrm{~kg}$ & $11,99 \mathrm{~kg}$ \\
\hline Brita 0 & $9,62 \mathrm{~kg}$ & $8,86 \mathrm{~kg}$ \\
\hline Água & 2,521 & 2,501 \\
\hline
\end{tabular}


Capítulo 3 - Desenvolvimento do Compósito

\begin{tabular}{c|c|c}
\hline $\begin{array}{c}\text { Superplastificante } \\
\text { Glenium }^{\circledR} 51\end{array}$ & $0,026 \mathrm{~kg}$ & $0,026 \mathrm{~kg}$ \\
\hline Sílica Ativa & $0,53 \mathrm{~kg}$ & $0,52 \mathrm{~kg}$ \\
\hline
\end{tabular}

*Consumo de cimento quando $10 \%$ foram substituídos por sílica ativa

Embora as taxas de fibras também fossem objeto de estudo, utilizou-se inicialmente a mesma quantidade proposta por Ferrari (2007), com o intuito de verificar o comportamento da matriz cimentícia. Foram utilizados $1 \%$ do volume de concreto de fibra (tipo A) e $2 \%$ do volume de microfibra (tipo C) para aferir a trabalhabilidade, sem ocorrência de segregação das fibras.

Os traços foram produzidos no Laboratório de Estruturas em misturadora de eixo vertical com capacidade para $0,25 \mathrm{~m}^{3}$. A sequência foi uma mistura rápida de areia e brita. Em seguida, acrescentou-se o cimento, parte da água, e novamente procedeu-se a mistura. $\mathrm{O}$ restante da água foi adicionado durante o movimento da misturadora, que em seguida recebeu as fibras e microfibras de aço. Por último adicionou-se o superplastificante e a mistura perdurou por mais três minutos.

Em duas misturas, a sequência foi alterada, acrescentando-se superplastificante antes das fibras, o que diminuiu significativamente a trabalhabilidade. $\mathrm{O}$ fato ocorreu com os dois traços que utilizavam sílica ativa. Mais adiante ver-se-á que a sílica, em ambos os casos, foi mera coincidência, sendo a sequência dos materiais responsável pela perda de fluidez.

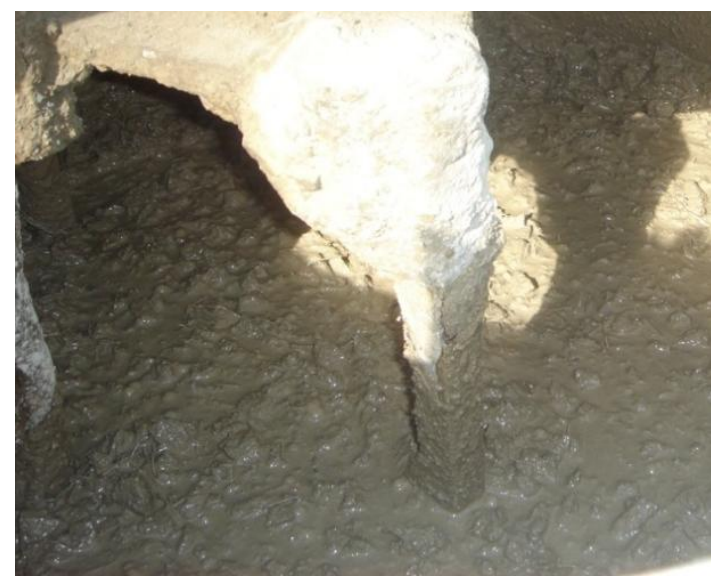

a) mistura dos componentes

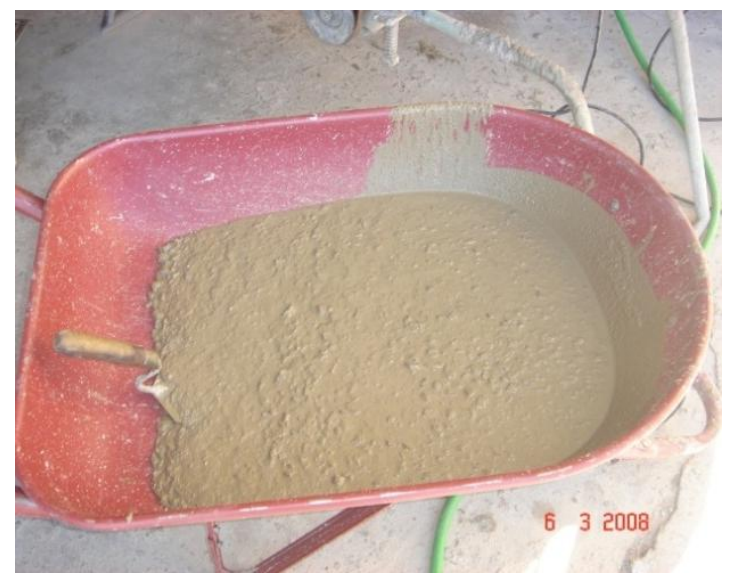

b) aspecto do concreto 


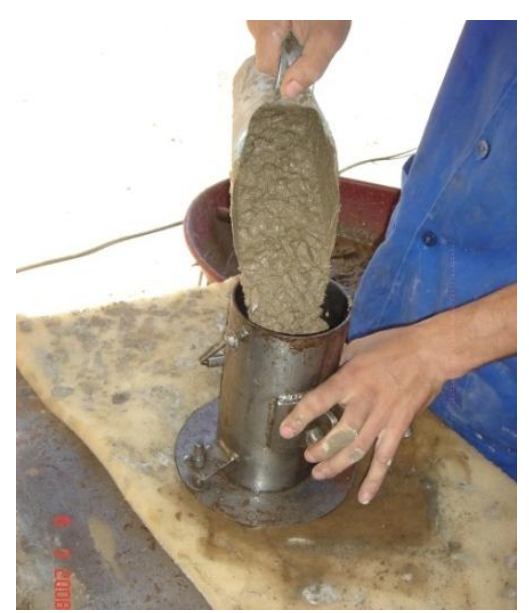

c) moldagem dos corpos de prova

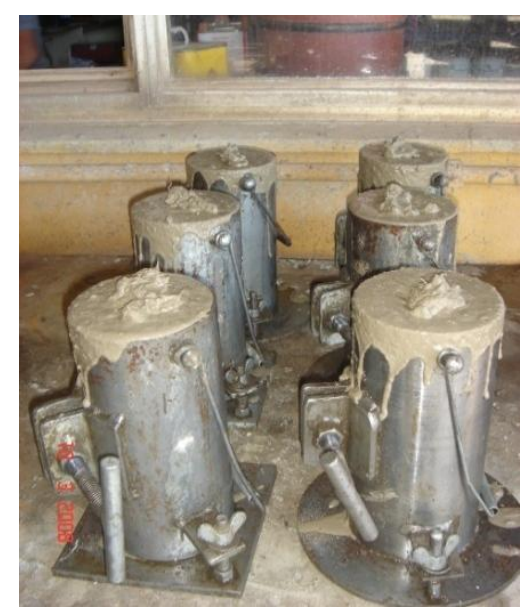

d) corpos de prova $10 \times 20 \mathrm{~cm}$

Figura 3.4 - Processo de fabricação dos corpos de prova

Após a moldagem, os seis corpos de prova cilíndricos de cada dosagem, foram vibrados em mesa vibratória por no máximo três segundos para que houvesse a compactação do concreto sem a orientação preferencial das fibras de aço (ACI 544.2R-89). Vinte e quatro horas depois, foram desmoldados e levados para a câmara úmida, onde permaneceram por mais seis dias.

Os corpos de prova foram testados à compressão e à tração aos sete dias de acordo com as normas ABNT NBR 5739 (1994) e ABNT NBR 7222 (1994) respectivamente, e os resultados encontram-se na Tabela 3.6:

Tabela 3.6 - Resultados médios da caracterização do concreto à compressão e à tração aos 7 dias

\begin{tabular}{c|c|c}
\hline Corpo de Prova & $\mathbf{f}_{\mathbf{c}}(\mathbf{M P a})$ & $\mathbf{f}_{\mathbf{c t}}(\mathbf{M P a})$ \\
\hline Série I SS & 47,35 & 5,43 \\
\hline Série I CS & 41,38 & 4,51 \\
\hline Série II SS & 43,76 & 5,69 \\
\hline Série II CS & 39,36 & 4,24 \\
\hline
\end{tabular}

Pela análise quantitativa, pode-se observar que em ambas as séries com sílica, a resistência à compressão do concreto foi inferior quando comparada aos respectivos traços sem sílica. Isso pode ser justificado pelo fato de que $10 \%$ do cimento de alta resistência inicial foram substituídos. Essa inferioridade não foi preocupante, já que a característica relevante para o trabalho é a resistência à tração. Nesse caso, a resposta não foi a esperada. A 
resistência à tração também foi significativamente reduzida em comparação com os respectivos traços sem sílica.

Sabendo que a sílica ativa precisa de um período de cura maior para apresentar resultados satisfatórios, os dois traços foram refeitos e rompidos com sete e quatorze dias para analisar a evolução da resistência à tração.

O consumo de material foi o mesmo, assim como a sequência da mistura, acrescentando-se o superplastificante por último. Ambos os traços apresentaram trabalhabilidade satisfatória, concluindo-se que a baixa fluidez do primeiro processo de mistura não estava relacionada à adição de sílica, mas sim à sequência de mistura dos materiais.

Os resultados obtidos à compressão e à tração das duas séries, aos sete e quatorze dias, estão na Tabela 3.7:

Tabela 3.7 - Resultados médios da caracterização do concreto à compressão e à tração

\begin{tabular}{cccc}
\hline Corpo de Prova & Idade & $\mathbf{f}_{\mathbf{c}}(\mathbf{M P a})$ & $\mathbf{f}_{\mathbf{c t}}(\mathbf{M P a})$ \\
\hline Série I CS & 7 dias & 50,44 & 4,51 \\
Série I CS & 14 dias & 53,56 & 4,67 \\
\hline Série II CS & 7 dias & 51,10 & 4,90 \\
Série II CS & 14 dias & 55,46 & 4,86 \\
\hline
\end{tabular}

Percebe-se que o período de quatorze dias ainda não foi suficiente para obter uma boa resposta da sílica. As melhoras foram mais representativas na resistência à compressão, que no caso específico do trabalho, não é de grande relevância. Além disso, o tempo também é um fator preponderante quando o assunto é reforço estrutural. Esperar mais que quatorze dias para obter resultados satisfatórios, seria contrário à proposta de um concreto em que se utiliza cimento de alta resistência inicial para rápida liberação da estrutura reforçada. Por isso, a proposta de usar sílica ativa foi descartada.

Voltando a analisar a Tabela 3.6, observa-se que a melhor resposta à tração foi obtida pelo traço Série II SS, embora com pouca diferença em relação ao traço Série I SS (cerca de 5\% superior). Mesmo assim, ele foi escolhido para dar continuidade ao trabalho.

Com relação aos aspectos físicos dos traços, pode-se observar, após os rompimentos dos corpos de prova, que em nenhum caso houve segregação de agregados ou fibras. 


\subsection{Compósito cimentício de alto desempenho (CCAD)}

Escolhida a matriz do compósito, o próximo passo foi encontrar as taxas adequadas de fibra e microfibra de aço a serem incorporadas. Nessa fase, como as características das fibras já estavam definidas, a atenção foi para que o volume não fosse exagerado a ponto de criar ninhos no concreto durante a mistura e para que não houvesse perda da trabalhabilidade. Por outro lado, o volume não poderia ser muito pequeno a ponto de não possibilitar melhoras à matriz. Ferrari (2007) não relatou problemas dessa natureza em seus compósitos, por isso, mais uma vez seu trabalho serviu como base.

Analisando o trabalho anterior, verificou-se que não houve variação no volume das fibras (tipo A), permanecendo constante e igual a $1 \%$ do volume de concreto (Tabela 3.8). Isso motivou a primeira proposta de estudo, que foi a inclusão da taxa de 1,5\%. A segunda proposta refere-se à observação de que a resistência encontrada para o traço CPM1A2C foi superior à encontrada para o traço CPM1A1C. Isso gerou a expectativa, de que, de repente, a taxa de 1,5\% de microfibra (tipo $\mathrm{C}$ ) pudesse apresentar resultados ainda melhores. Por último, a taxa de $2,5 \%$ de microfibra (tipo C) foi eliminada por proporcionar baixos resultados.

Tabela 3.8 - Taxas de fibra e microfibra analisadas no trabalho anterior (Adaptado de FERRARI, 2007, p.135)

\begin{tabular}{|c|c|c|c|}
\hline Material & Compósitos & Taxa de fibra & Tipo de fibra \\
\hline \multirow{5}{*}{$\begin{array}{l}0 \\
0 \\
0 \\
0 \\
0 \\
0 \\
0 \\
: 0 \\
:\end{array}$} & CPM & $0 \%$ & - \\
\hline & CPM1A & $1 \%$ & $\mathrm{~A}$ \\
\hline & CPM1A1C & $1 \%+1 \%$ & $A+C$ \\
\hline & CPM1A2C & $1 \%+2 \%$ & $A+C$ \\
\hline & CPM1A2.5C & $1 \%+2,5 \%$ & $A+C$ \\
\hline
\end{tabular}

Resumindo, as taxas de fibras (tipo A) e microfibras (tipo C) propostas neste trabalho foram: 
Tabela 3.9 - Taxas de fibra e microfibra analisadas neste trabalho

\begin{tabular}{|c|c|c|c|}
\hline Material & Compósitos & Taxa de fibra & Tipo de fibra \\
\hline \multirow{6}{*}{ 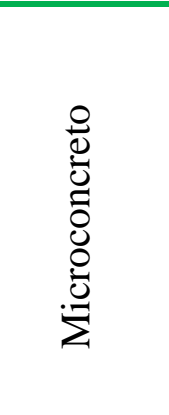 } & CPM1A1C & $1 \%+1 \%$ & $A+C$ \\
\hline & CPM1A1,5C & $1 \%+1,5 \%$ & $A+C$ \\
\hline & CPM1A2C & $1 \%+2 \%$ & $A+C$ \\
\hline & CPM1,5A1C & $1,5 \%+1 \%$ & $A+C$ \\
\hline & CPM1,5A1,5C & $1,5 \%+1,5 \%$ & $A+C$ \\
\hline & CPM1,5A2C & $1,5 \%+2 \%$ & $A+C$ \\
\hline
\end{tabular}

Observa-se que a escolha das taxas não foi baseada em métodos técnicos, mas de maneira empírica. Embora muitos autores relatem pesquisas sobre fibras de aço, poucos discutem o assunto de dosagem. Além disso, o material microfibra ainda é uma incógnita.

Para escolha de um compósito, dentre as seis possibilidades idealizadas, foi realizado ensaio à flexão, descrito na próxima seção, com o objetivo de obter as resistências relevantes do material que fará parte do reforço da viga.

\subsection{RILEM TC 162-TDF}

A escolha de um compósito que apresente as características requeridas para um material de reforço, passa pelo custo do material, pela trabalhabilidade apresentada, pelas resistências adquiridas e pelo seu comportamento durante o tempo de vida útil. Sabe-se que no reforço à flexão de vigas, necessita-se de uma propriedade do concreto que é praticamente desprezível, que é a tração. Por isso, optou-se por incorporar fibras de aço ao material, não com o objetivo de melhorar a resistência à tração da matriz, mas sim com o objetivo de aumentar a tenacidade à abertura de fissuras do compósito, o que proporcionaria maior vida útil à estrutura e maior capacidade de carga do reforço, evitando em muitos casos, o desprendimento do laminado.

Para avaliar as melhorias proporcionadas pela adição de fibras de aço ao concreto, foi realizado o ensaio proposto pela RILEM TC 162-TDF (2002b). Optou-se por esse ensaio por ser de fácil realização, fornecer resultados satisfatórios e pela respeito no âmbito mundial que a entidade goza. 
O método da RILEM TC 162-TDF (2002b) avalia o comportamento do concreto pelo ensaio à flexão em três pontos, realizado em viga entalhada no sentido transversal, no meio de seu comprimento. Com base nos gráficos força $x$ deslocamento vertical ou força $x$ abertura da fissura obtidos durante o ensaio, obtém-se o limite de proporcionalidade e mais quatro parâmetros, designados de resistências equivalentes e resistências residuais em flexão determinados em pontos específicos. Mesmo adquirindo cinco índices, a RILEM TC 162TDF (2003) classifica o concreto reforçado com fibras de aço com base em apenas dois deles, que são as forças de flexão residual.

O ensaio consiste em uma viga de concreto não armado entalhada, onde são medidos o deslocamento vertical e a abertura da fissura pré-existente durante a aplicação da carga. A Figura 3.5 apresenta a configuração do ensaio, que possui como vantagem rápida montagem:

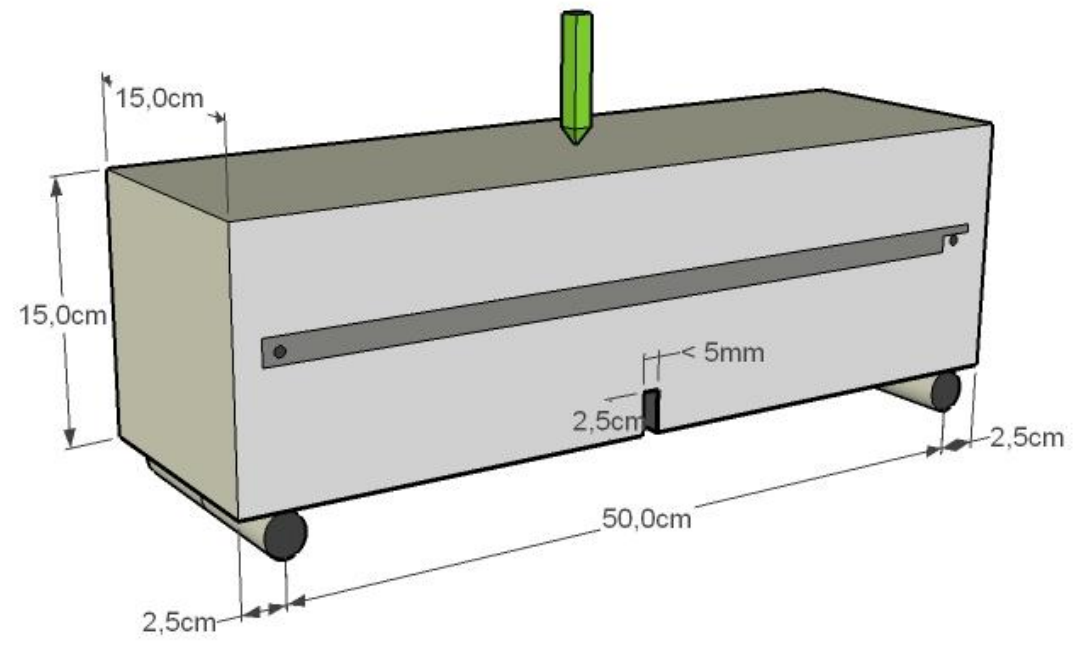

Figura 3.5 - Configuração do ensaio

O gráfico desenhado com os dados obtidos durante a execução do ensaio é semelhante ao apresentado na Figura 3.6. Por dele é possível calcular os parâmetros que caracterizam o comportamento do concreto. 


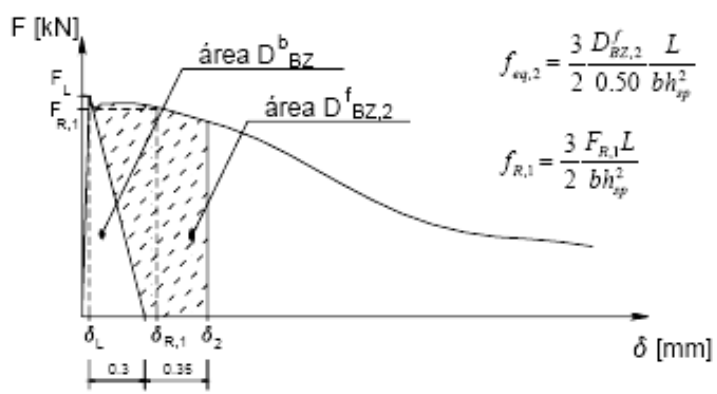

a)

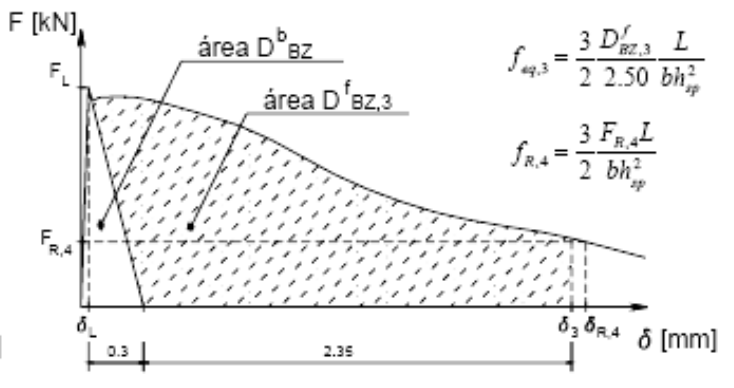

b)

Resistência equivalente e residual à tração em flexão: a) $f_{e q, 2}$ e $f_{R l}$; b) $f_{e q, 3}$ e $f_{R 4}\left(\delta_{\mathrm{L}}=0,05 \mathrm{~mm}\right)$

Figura 3.6 - Exemplo do gráfico obtido no ensaio de fraturamento (Adaptado de BARROS, 2003, p.2.7)

O primeiro valor retirado do gráfico é o de $F_{L}$ que corresponde ao maior valor de carga compreendido no intervalo entre 0 e $0,05 \mathrm{~mm}$ do deslocamento vertical ou abertura da fissura. Este valor corresponde ao limite de proporcionalidade. Com isso, é possível calcular a resistência à tração na flexão ou tensão no limite de proporcionalidade (Equação 3.1):

$$
f_{f c t, L}=\frac{3 \cdot F_{L} \cdot L}{2 \cdot b \cdot h_{s p}^{2}}
$$

onde:

$f_{f c t, L}=$ resistência à tração na flexão ou tensão no limite de proporcionalidade $\left(\mathrm{N} / \mathrm{mm}^{2}\right)$;

$F_{L}=$ carga máxima dentro do intervalo 0 e $0,05 \mathrm{~mm}$ do deslocamento vertical ou abertura da fissura $(\mathrm{N})$;

$L=$ comprimento do corpo de prova $(\mathrm{mm})$

$b=$ largura do corpo de prova $(\mathrm{mm})$;

$h_{s p}=$ distância entre a ponta do entalhe e a face superior do corpo de prova $(\mathrm{mm})$.

A capacidade de absorção de energia $\left(D_{B Z, 2}\right.$ e $\left.D_{B Z, 3}\right)$ do compósito pode ser dividida em duas partes: uma referente à matriz cimentícia $\left(D^{b}{ }_{B Z}\right)$ e outra referente às fibras $\left(D_{B Z, 2}^{f} \mathrm{e}\right.$ $D_{B Z, 3)}^{f}$. Esta última parcela é calculada pela área abaixo da curva força $x$ deslocamento até as deformações pré-determinadas $\delta_{2}$ e $\delta_{3}$, descontada a área referente à matriz cimentícia. 
A linha que divide a influência da matriz, da influência das fibras, pode ser simplificada por uma reta cujo ponto inicial é o valor de $F_{L}$ e ponto final o valor de deslocamento correspondente à $\delta_{L}+0,3 \mathrm{~mm}$, onde $\delta_{L}$ corresponde ao deslocamento do limite de proporcionalidade (Figura 3.5). A partir desse ponto, define-se também, os valores prédeterminados de $\delta_{2}$ e $\delta_{3}$ (Equações 3.2 e 3.3):

$$
\begin{aligned}
& \delta_{2}=\delta_{L}+0,65(\mathrm{~mm}) \\
& \delta_{3}=\delta_{L}+2,65(\mathrm{~mm})
\end{aligned}
$$

Ainda de acordo com a RILEM TC 162-TDF (2002b), considerando uma distribuição linear de tensões na seção de fratura e desprezando a parcela de energia absorvida pela matriz cimentícia, as tensões equivalentes de tração na flexão $f_{e q, 2}$ e $f_{e q, 3}$ podem ser calculadas pelas seguintes expressões:

$$
\begin{aligned}
f_{e q, 2} & =\frac{3 \cdot D_{B Z, 2}^{f} \cdot L}{2 \cdot 0,50 \cdot b \cdot h_{s p}^{2}} \\
f_{e q, 3} & =\frac{3 \cdot D_{B Z, 3}^{f} \cdot L}{2 \cdot 0,50 \cdot b \cdot h_{s p}^{2}}
\end{aligned}
$$

onde:

$f_{e q, i .}=$ tensão equivalente à tração na flexão ou tensão no limite de proporcionalidade nos pontos 2 e $3\left(\mathrm{~N} / \mathrm{mm}^{2}\right)$;

$D_{B Z, 2}^{f}=$ área abaixo da curva força $x$ deslocamento até o ponto $\delta_{2}=\delta_{L}+0,65(\mathrm{~mm})$, desprezando a parcela referente à $D^{b}{ }_{B Z}$;

$D_{B Z, 3}^{f}=$ área abaixo da curva força $x$ deslocamento até o ponto $\delta_{3}=\delta_{L}+2,65(\mathrm{~mm})$, desprezando a parcela referente à $D^{b}{ }_{B Z}$;

$L=$ comprimento do corpo de prova (mm);

$b=$ largura do corpo de prova (mm); 
$h_{s p}=$ distância entre a ponta do entalhe e a face superior do corpo de prova (mm).

Por fim, as tensões residuais podem ser calculadas através da Equação 3.6:

$$
\begin{gathered}
f_{R, i}=\frac{3 \cdot F_{R, i} \cdot L}{2 \cdot b \cdot h_{s p}^{2}} \\
\mathrm{CMOD}_{1}=0,5 \mathrm{~mm}-\delta_{\mathrm{R}, 1}=0,46 \mathrm{~mm} \\
\mathrm{CMOD}_{2}=1,5 \mathrm{~mm}-\delta_{\mathrm{R}, 2}=1,31 \mathrm{~mm} \\
\mathrm{CMOD}_{3}=2,5 \mathrm{~mm}-\delta_{\mathrm{R}, 3}=2,15 \mathrm{~mm} \\
\mathrm{CMOD}_{4}=3,5 \mathrm{~mm}-\delta_{\mathrm{R}, 4}=3.00 \mathrm{~mm}
\end{gathered}
$$

onde:

$f_{r i}=$ tensão de flexão residual no ponto $i\left(\mathrm{~N} / \mathrm{mm}^{2}\right)$;

$F_{R i}=$ carga registrada no ponto de $C M O D_{i}$ ou $\delta_{R, i}(\mathrm{~N}) ;$

$L=$ comprimento do corpo de prova $(\mathrm{mm})$;

$b=$ largura do corpo de prova $(\mathrm{mm})$;

$h_{s p}=$ distância entre a ponta da fissura e a face superior do corpo de prova (mm).

Com as tensões de flexão residual $f_{R l}$ e $f_{R 4}$, são determinados os parâmetros $\mathrm{F}_{\mathrm{L} 0,5}$ e $\mathrm{F}_{\mathrm{L} 3,5}$, respectivamente, como exposto na seção 2.1.5. O s valores de $\mathrm{F}_{\mathrm{L} 0,5}$ e $\mathrm{F}_{\mathrm{L} 3,5}$, que coincidem com os valores de $f_{R I}$ e $f_{R 4}$, devem ser reduzidos em múltiplos de $0,5 \mathrm{MPa}$ e devem variar entre $1 \mathrm{e}$ $6 \mathrm{MPa}$ e 0 e $4 \mathrm{MPa}$, respectivamente. Com isso, a classe de resistência residual é representada por $\mathrm{F}_{\mathrm{L}} \mathrm{F}_{\mathrm{L} 0,5} / \mathrm{FL}_{3,5}$ com seus correspondentes valores.

\subsection{Configuração e realização do ensaio}

Conforme exposto, o ensaio de fraturamento foi baseado nas exigências propostas pela RILEM TC 162-TDF (2002b). Porém, alguns itens tiveram que ser revistos por questões de 
tempo disponível no laboratório, como por exemplo, número de corpos de prova e velocidade de ensaio. A norma exige que sejam realizados ao menos seis ensaios para cada traço de concreto mas, no caso, foram realizados cinco. A velocidade do ensaio, controlado pela abertura da fissura, deve ser de $50 \mu \mathrm{m} / \mathrm{min}$ até abertura de $0,1 \mathrm{~mm}$ e daí em diante, permanecer constante e igual a $0,2 \mathrm{~mm} / \mathrm{min}$. Nos ensaios, foram utilizadas as velocidades de $0,06 \mathrm{~mm} / \mathrm{min}$ como inicial e depois constante e igual a $0,3 \mathrm{~mm} / \mathrm{min}$.

Outra alteração foi com relação às dimensões do corpo de prova que, segundo a norma, são de 15 x 15 x $550 \mathrm{~mm}$, mas as formas metálicas disponíveis no laboratório são de 15 x 15 x $500 \mathrm{~mm}$. Com isso, o vão entre apoios, que deveria ser de $500 \mathrm{~mm}$, foi de $450 \mathrm{~mm}$.

Com exceção dos itens relatados, as demais imposições feitas pela RILEM TC 162TDF (2002b) foram devidamente cumpridas. O entalhe realizado na viga segue a exigência da norma, que especifica espessura menor ou igual a $5 \mathrm{~mm}$ e a altura igual a $2,5 \mathrm{~cm} \pm 1 \mathrm{~mm}$. O objetivo é criar uma fissura a partir da qual o ensaio deve se desenvolver. Caso uma nova fissura se forme fora do entalhe, o ensaio deve ser descartado. Outro item importante e também respeitado faz menção à base de sustentação da viga, que deve ser suficientemente rígida para evitar zonas de instabilidade no gráfico força $x$ deslocamento. Rótulas foram utilizadas nos apoios e no ponto de aplicação de carga para permitir a livre rotação do corpo de prova, como sugere a norma.

\subsubsection{Caracterização do concreto}

Para analisar o comportamento dos seis compósitos propostos, foram confeccionadas cinco vigas não armadas, mais seis corpos de prova cilíndricos 10 x $20 \mathrm{~cm}$ para cada traço. Todos os concretos foram produzidos no Laboratório de Estruturas, divididos em três datas de moldagem.

O consumo de material para produção da matriz cimentícia, comum a todos os compósitos, pode ser visualizado na Tabela 3.10: 
Capítulo 3 - Desenvolvimento do Compósito

Tabela 3.10 - Consumo de material para produção da matriz cimentícia

\begin{tabular}{c|c|c}
\hline \multicolumn{3}{c}{ Traço $=\mathbf{1}: \mathbf{2 , 3 0}: \mathbf{1 , 7 0 : 0 , 4 8}(\mathbf{e m ~ m a s s a})$} \\
\hline Material & Consumo $(\mathbf{k g})$ & Consumo $\left(\mathbf{k g} / \mathbf{m}^{\mathbf{3}}\right)$ \\
\hline Cimento CPV ARI & 32,0 & 443,0 \\
\hline Areia & 73,59 & 1018,9 \\
\hline Brita 0 & 54,39 & 753,1 \\
\hline Água & 15,36 & 212,6 \\
\hline $\begin{array}{c}\text { Superplastificante } \\
\text { Glenium }\end{array}{ }^{\circledR} 51$ & 0,16 & 2,22 \\
\hline
\end{tabular}

Os consumos de fibra (tipo A) e microfibra (tipo C) para cada compósito foram os seguintes (Tabela 3.11):

Tabela 3.11 - Consumo de fibras para produção dos compósitos

\begin{tabular}{c|c|c}
\hline Traços & $\begin{array}{c}\text { Fibra (tipo A) } \\
(\mathbf{k g})\end{array}$ & $\begin{array}{c}\text { Microfibra (tipo C) } \\
(\mathbf{k g})\end{array}$ \\
\hline CPM1A1C & 5,66 & 5,66 \\
\hline CPM1A1,5C & 5,66 & 8,50 \\
\hline CPM1A2C & 5,66 & 11,33 \\
\hline CPM1,5A1C & 8,50 & 5,66 \\
\hline CPM1,5A1,5C & 8,50 & 8,50 \\
\hline CPM1,5A2C & 8,50 & 11,33 \\
\hline
\end{tabular}

A sequência foi a mesma descrita anteriormente e em seguida realizou-se a moldagem das vigas e dos corpos de prova cilíndricos. Assim como no ensaio precedente a este, todos foram vibrados em mesa vibratória por no máximo três segundos, para que houvesse a compactação do concreto sem a orientação preferencial das fibras de aço. Após 24 horas da moldagem, os corpos de prova e as vigas foram retirados das formas e levados para a câmara úmida, onde permaneceram até a data do ensaio.

Notou-se uma considerável perda de trabalhabilidade nos traços CPM1,5A1,5C e CPM1,5A2C. 


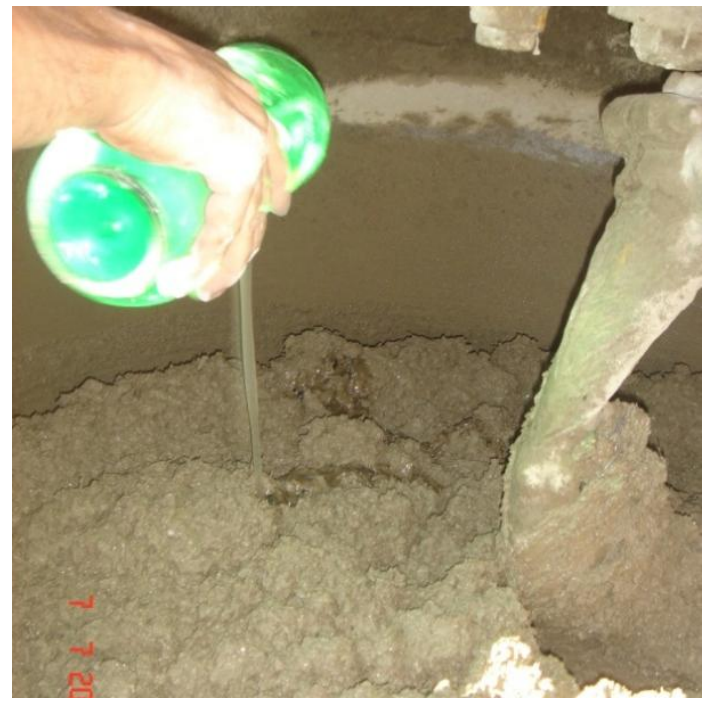

a) aspecto do concreto antes da adição de superplastificante

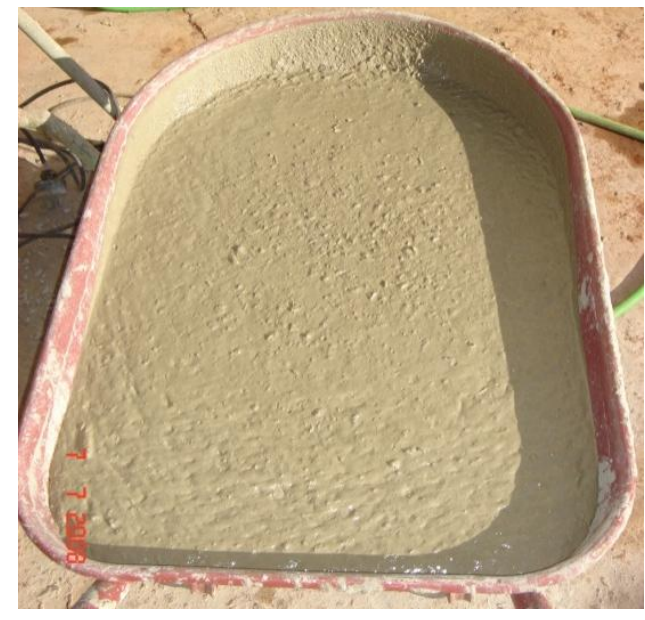

c) aspecto final do concreto

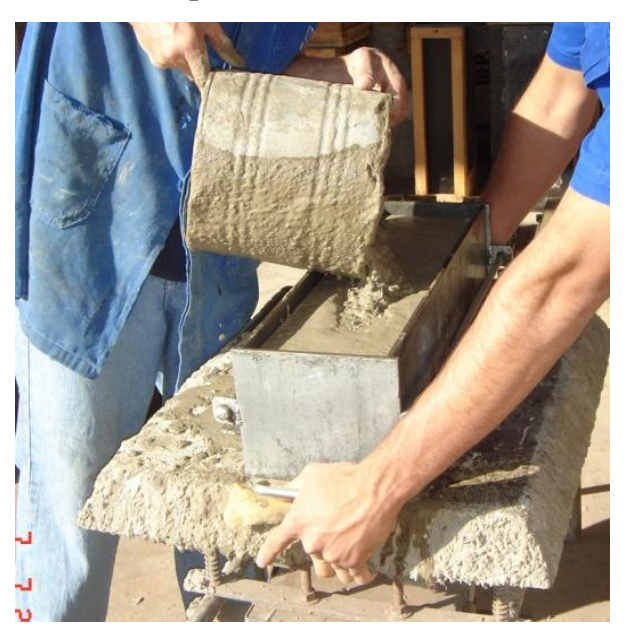

e) moldagem das vigas

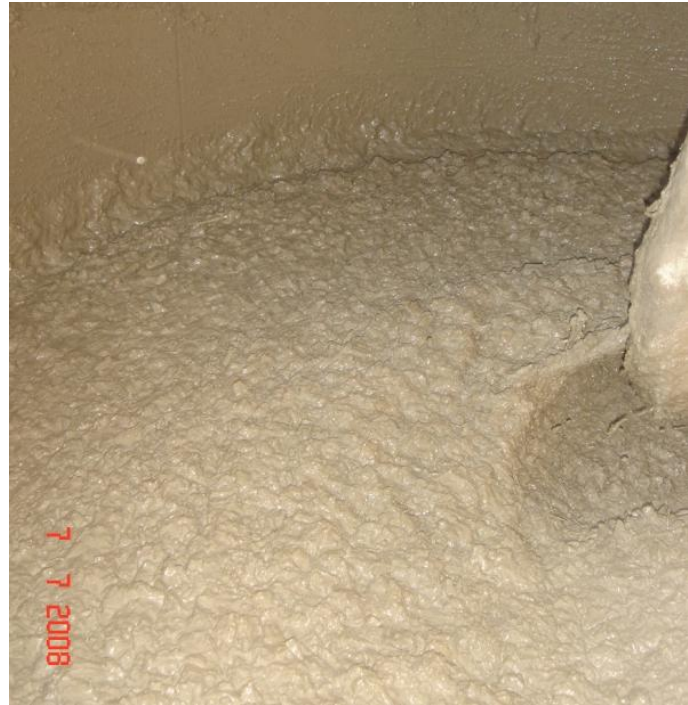

b) aspecto do concreto após a adição de superplastificante

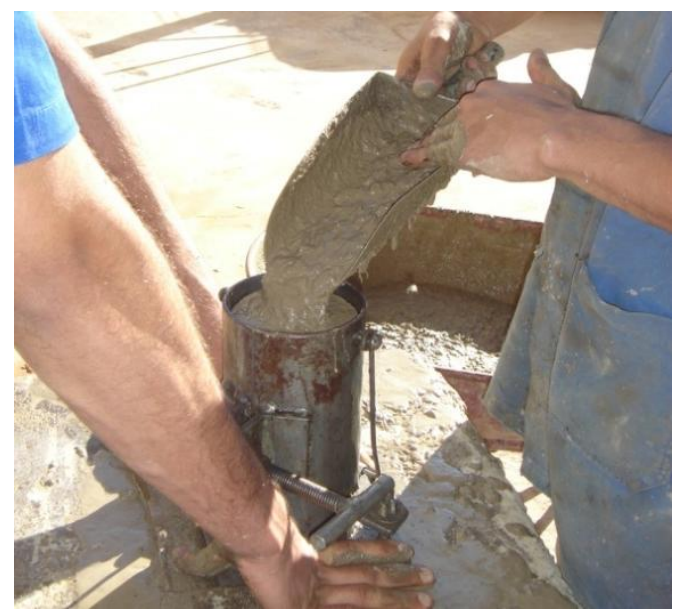

d) moldagem dos corpos de prova cilíndricos

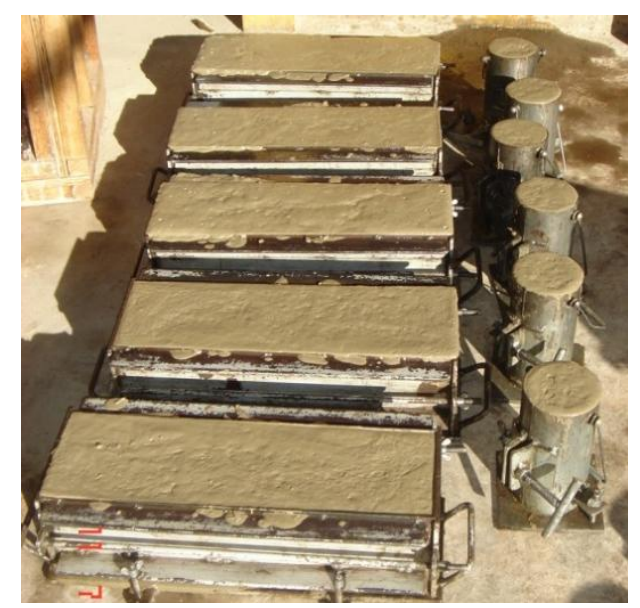

f) corpos de prova

Figura 3.7 - Processo de preparação das vigas e corpos de prova 
Quase dois meses depois, os corpos de prova cilíndricos foram ensaiados à compressão (ABNT NBR 5739:1994) e à tração (ABNT NBR 7222:1994), nos mesmos dias em que as vigas de seus respectivos traços foram ensaiadas ao fraturamento. Os resultados médios encontram-se na Tabela 3.12:

Tabela 3.12 - Resultados médios dos ensaios de caracterização do concreto à compressão e à tração

\begin{tabular}{c|c|c|c|c}
\hline $\begin{array}{c}\text { Corpo de } \\
\text { Prova }\end{array}$ & $\mathbf{f}_{\mathbf{c}}(\mathbf{M P a})$ & $\left.\mathbf{f}_{\mathbf{t}} \mathbf{( M P a}\right)$ & $\begin{array}{c}\text { Módulo de } \\
\text { elasticidade } \\
\mathbf{( M P a})\end{array}$ & $\begin{array}{c}\text { Módulo de } \\
\text { elasticidade }(\mathbf{M P a}) \\
\text { ABNT NBR 6118 }\end{array}$ \\
\hline CPM1A1C & 33,21 & 2,48 & 25644,21 & 32271,75 \\
\hline CPM1A1,5C & 30,63 & 2,24 & 26165,88 & 30992,85 \\
\hline CPM1A2C & 33,40 & 3,17 & 28830,86 & 32363,93 \\
\hline CPM1,5A1C & 28,31 & 2,63 & 23016,31 & 29795,00 \\
\hline CPM1,5A1,5C & 30,49 & 2,86 & 23485,31 & 30921,94 \\
\hline CPM1,5A2C & 29,15 & 2,39 & 23053,95 & 30234,81 \\
\hline
\end{tabular}

Comparando esses resultados com aqueles obtidos nos ensaios preliminares (Tabela 3.6), nota-se uma considerável perda de resistência do concreto, estando bem abaixo do objetivo proposto que é de $50 \mathrm{MPa}$, mesmo em idade mais avançada. Nenhum motivo notável foi verificado durante a produção desses compósitos para justificar tal fato, a não ser a mudança de lotes dos componentes do concreto.

Observa-se que o traço CPM1A2C, que coincide com o traço do estudo preliminar da matriz cimentícia, embora tenha apresentado a melhor resposta no ensaio à tração, ficou abaixo do resultado encontrado anteriormente, que foi de 5,69 MPa. Nenhum motivo específico foi percebido para justificar tal diferença.

Com a taxa de fibra (tipo A) de 1,5\%, os valores da resistência à compressão foram inferiores aos traços com 1\%. O aumento do volume de fibras dificulta a compactação, ocasionando a incorporação de ar na matriz cimentícia. Essa redução é esperada e até comentada no ACI 544-2R (1989). Já a resistência à tração não teve muita variação a não ser pelo valor de 3,17 MPa do traço CPM1A2C. Coincidência ou não, os melhores resultados à tração, foram conquistados com traços que somavam 3\% de inserção de fibras. 
Com relação aos módulos de elasticidade, os resultados foram satisfatórios. Com o aumento da taxa de fibra (tipo A), os compósitos se tornaram mais dúcteis, com maiores deformações para a mesma carga aplicada. Se esses valores forem comparados aos valores teóricos sugeridos pela ABNT NBR 6118 (2003), fica mais evidente a melhora conquistada.

\subsubsection{Ensaio}

Um dia antes da realização do ensaio, as vigas foram entalhadas com auxílio de disco de corte por meio de via úmida, ficando a abertura com aproximadamente $2 \mathrm{~mm}$ de espessura e 2,5 $\mathrm{mm}$ de profundidade. Ao término, as vigas foram lavadas e mantidas na parte externa do laboratório para secagem.

Em geral, a montagem do ensaio foi bastante simples e consistiu na utilização de um atuador servo-hidráulico Instron com capacidade nominal de 100 kN, um sistema de aquisição de dados System 5000 da Vishay, um Clip Gauge da marca MSI com abertura inicial de 10 mm e um transdutor de deslocamento da marca Vishay com percurso de $25 \mathrm{~mm}$, fixado a um suporte de aço conhecido por "Yoke". Esse suporte é exigido em todas as normas recentes de ensaios de tenacidade à flexão, por ser de alta confiabilidade uma vez que toma o próprio corpo de prova como referência para medir o deslocamento vertical (FIGUEIREDO, 2005). Para isto, é importante sua correta fixação, que deve acontecer no alinhamento dos apoios e à meia altura da viga.

A Figura 3.8 mostra a situação esquemática do ensaio:

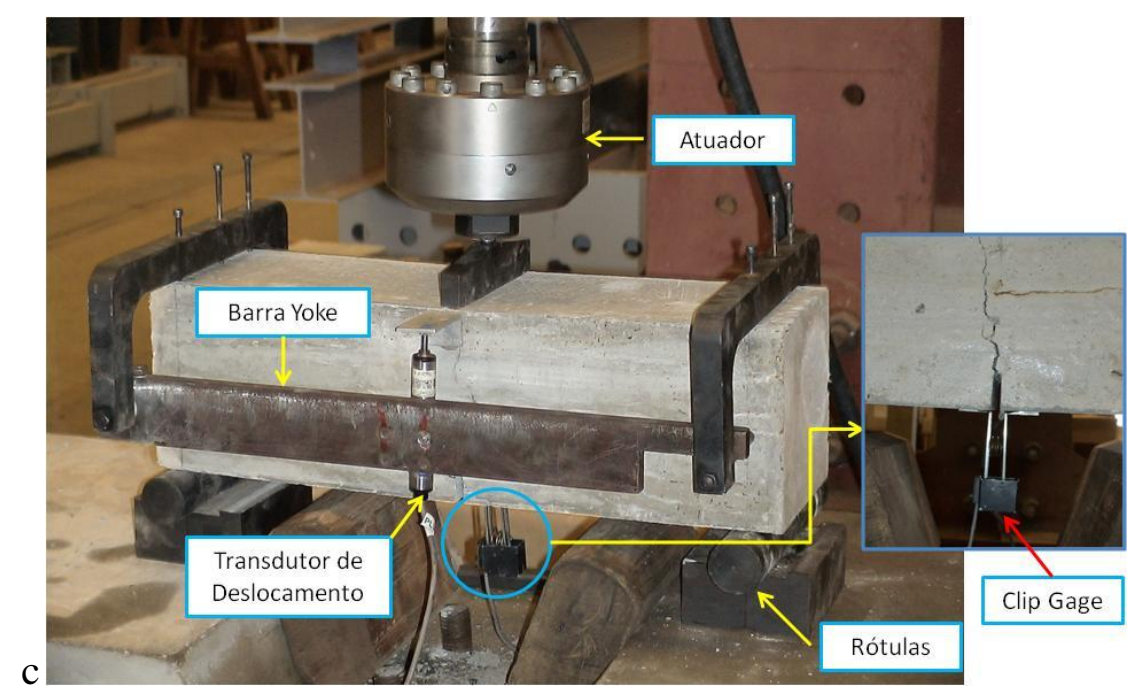

Figura 3.8 - Situação esquemática do ensaio 
A Figura 3.9 apresenta a viga em um processo mais avançado de fissuração:

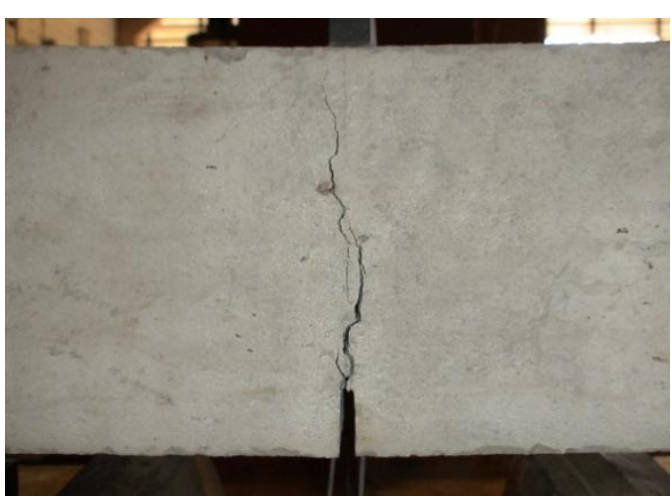

a) detalhe da abertura da fissura

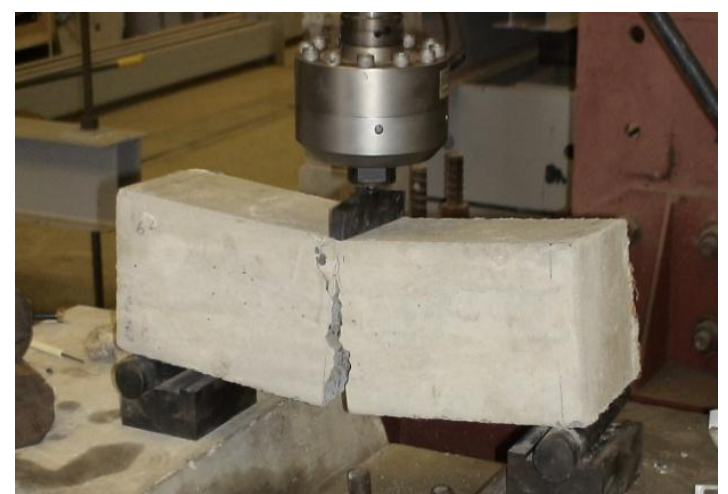

b) rompimento da viga após ensaio

Figura 3.9 - Vigas em processo avançado de fissuração

Após o rompimento das vigas, foi possível observar as fibras distribuídas aleatoriamente na seção sem qualquer indício de segregação. A Figura 3.10 mostra a situação de uma delas:

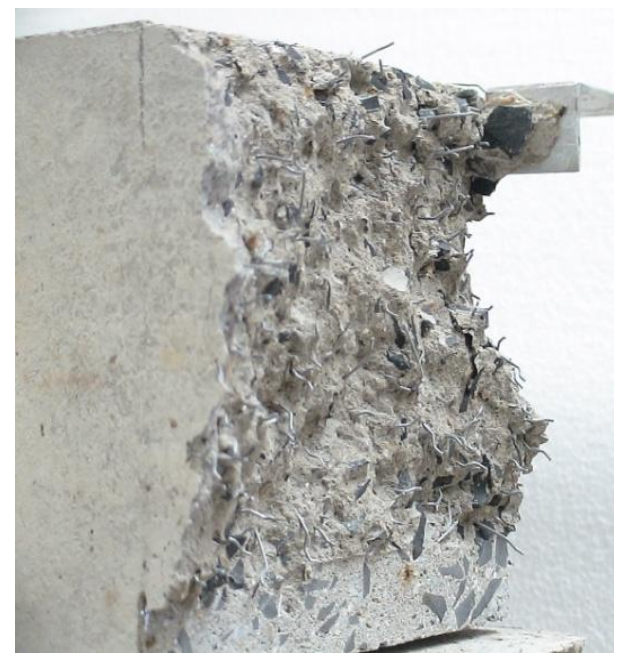

Figura 3.10 - Aspecto da distribuição aleatória das fibras

\subsection{Resultados e análises}

Após a realização dos ensaios, o gráfico força $x$ deslocamento vertical foi construído para todos os corpos de provas (Figura 3.11) e em seguida foram calculados os parâmetros discutidos na seção 3.3, cujos resultados estão apresentados na Tabela 3.13: 
Capítulo 3 - Desenvolvimento do Compósito

Tabela 3.13 - Resultados dos parâmetros propostos pela RILEM (2002b)

\begin{tabular}{|c|c|c|c|c|c|c|c|c|c|c|}
\hline \multirow{2}{*}{\multicolumn{2}{|c|}{ Compósitos }} & \multicolumn{4}{|c|}{ Forças } & \multicolumn{5}{|c|}{ Resistências } \\
\hline & & \multirow{2}{*}{$\begin{array}{c}\begin{array}{c}\mathbf{F}_{\mathbf{L}} \\
(\mathbf{k N})\end{array} \\
13,13 \\
\end{array}$} & \multirow{2}{*}{$\begin{array}{c}\begin{array}{c}\mathbf{F}_{\mathbf{M}}{ }^{*} \\
(\mathbf{k N})\end{array} \\
17,48\end{array}$} & \multirow{2}{*}{$\begin{array}{l}\mathbf{F}_{\mathbf{R}, \mathbf{1}} \\
(\mathbf{k N})\end{array}$} & \multirow{2}{*}{$\begin{array}{c}\begin{array}{c}\mathbf{F}_{\mathbf{R}, \mathbf{4}} \\
(\mathbf{k N})\end{array} \\
4,83 \\
\end{array}$} & \multirow{2}{*}{$\begin{array}{c}\begin{array}{c}\mathbf{f}_{\text {fct, }} \\
\text { (MPa) }\end{array} \\
3,86 \\
\end{array}$} & \multirow{2}{*}{$\begin{array}{c}\begin{array}{c}\mathbf{f}_{\text {eq,2 }} \\
(\mathbf{M P a})\end{array} \\
4,65\end{array}$} & \multirow{2}{*}{$\begin{array}{c}\begin{array}{c}\mathbf{f}_{\text {eq,3 }} \\
(\mathbf{M P a})\end{array} \\
2,99\end{array}$} & \multirow{2}{*}{$\begin{array}{c}\begin{array}{c}\mathbf{f}_{\mathbf{R}, \mathbf{1}} \\
(\mathbf{M P a})\end{array} \\
4,25 \\
\end{array}$} & \multirow{2}{*}{$\begin{array}{c}\begin{array}{c}\mathbf{f}_{\mathbf{R}, 4} \\
(\mathbf{M P a})\end{array} \\
1,42 \\
\end{array}$} \\
\hline \multirow{6}{*}{ 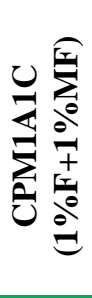 } & 1 & & & & & & & & & \\
\hline & 2 & 12,07 & 12,83 & 10,09 & 0,00 & 4,01 & 3,10 & 2,17 & 3,15 & 0,00 \\
\hline & 3 & 14,16 & 15,83 & 14,21 & 0,00 & 4,19 & 4,35 & 3,20 & 4,20 & 0,00 \\
\hline & 4 & 10,69 & 12,95 & 8,45 & 0,00 & 3,02 & 2,57 & 1,52 & 2,39 & 0,00 \\
\hline & 5 & 10,91 & 12,38 & 9,64 & 0,00 & 3,13 & 2,91 & 2,05 & 2,76 & 0,00 \\
\hline & Média & 12,19 & 14,29 & 11,37 & 0,97 & 3,64 & 3,52 & 2,39 & 3,35 & 0,28 \\
\hline \multirow{6}{*}{ 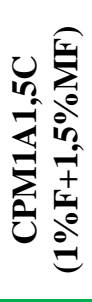 } & 1 & 11,31 & 12,65 & 9,59 & 3,59 & 3,31 & 2,87 & 1,93 & 2,81 & 1,05 \\
\hline & 2 & 13,08 & 17,84 & 15,32 & 0,00 & 3,89 & 4,94 & 3,26 & 4,56 & 0,00 \\
\hline & 3 & 15,34 & 18,06 & 15,06 & 5,60 & 4,55 & 4,70 & 3,16 & 4,47 & 1,66 \\
\hline & 4 & 9,23 & 14,51 & 11,79 & 4,45 & 2,65 & 3,80 & 2,47 & 3,39 & 1,28 \\
\hline & 5 & 11,15 & 12,67 & 8,76 & 0,00 & 3,27 & 2,72 & 1,65 & 2,57 & 0,00 \\
\hline & Média & 12,02 & 15,15 & 12,11 & 2,73 & 3,53 & 3,81 & 2,49 & 3,56 & 0,80 \\
\hline \multirow{6}{*}{ 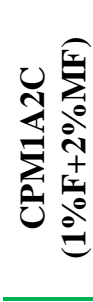 } & 1 & 13,81 & 18,81 & 15,66 & 0,00 & 3,88 & 4,80 & 2,96 & 4,40 & 0,00 \\
\hline & 2 & 12,78 & 17,46 & 13,26 & 3,46 & 3,81 & 4,39 & 2,42 & 3,95 & 1,03 \\
\hline & 3 & 14,78 & 20,38 & 17,18 & 0,00 & 4,25 & 5,37 & 3,36 & 4,94 & 0,00 \\
\hline & 4 & 15,21 & 18,49 & 15,87 & 0,00 & 4,31 & 4,74 & 2,94 & 4,50 & 0,00 \\
\hline & 5 & 15,27 & 19,56 & 17,38 & 5,76 & 4,33 & 5,22 & 3,31 & 4,93 & 1,63 \\
\hline & Média & 14,37 & 18,94 & 15,87 & $\mathbf{1 , 8 4}$ & 4,12 & 4,90 & 3,00 & 4,54 & 0,53 \\
\hline \multirow{6}{*}{ 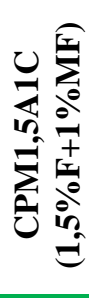 } & 1 & 13,85 & 18,61 & 15,15 & 0,00 & 3,97 & 4,72 & 2,78 & 4,34 & 0,00 \\
\hline & 2 & 13,40 & 18,55 & 14,92 & 0,00 & 3,81 & 4,68 & 3,05 & 4,24 & 0,00 \\
\hline & 3 & 16,54 & 22,93 & 20,19 & 0,00 & 4,78 & 6,38 & 0,00 & 5,84 & 0,00 \\
\hline & 4 & 11,04 & 15,33 & 14,35 & 6,07 & 3,20 & 4,40 & 3,03 & 4,16 & 1,76 \\
\hline & 5 & 9,26 & 16,97 & 15,45 & 5,78 & 2,60 & 4,75 & 3,11 & 4,34 & 1,62 \\
\hline & Média & 12,82 & 18,48 & 16,01 & 2,37 & 3,67 & 4,99 & 2,39 & 4,59 & 0,68 \\
\hline \multirow{6}{*}{ 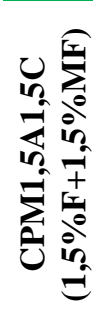 } & 1 & 16,65 & 22,24 & 21,29 & 0,00 & 4,65 & 6,21 & 4,21 & 5,94 & 0,00 \\
\hline & 2 & 14,13 & 17,27 & 13,73 & 0,00 & 4,07 & 4,27 & 3,03 & 3,95 & 0,00 \\
\hline & 3 & 13,70 & 18,39 & 15,56 & 6,52 & 3,81 & 4,70 & 3,17 & 4,32 & 1,81 \\
\hline & 4 & 16,00 & 20,68 & 18,42 & 0,00 & 4,60 & 5,61 & 3,58 & 5,29 & 0,00 \\
\hline & 5 & 15,30 & 20,32 & 18,58 & 0,00 & 4,49 & 5,80 & 3,77 & 5,45 & 0,00 \\
\hline & Média & 15,16 & 19,78 & 17,51 & 1,30 & 4,32 & 5,32 & 3,55 & 4,99 & 0,36 \\
\hline \multirow{6}{*}{ 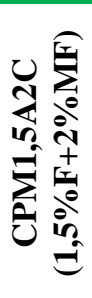 } & 1 & 13,13 & 16,19 & 14,49 & 0,00 & 3,84 & 4,47 & 2,86 & 4,33 & 0,00 \\
\hline & 2 & 7,15 & 15,36 & 13,30 & 5,25 & 1,95 & 4,21 & 2,68 & 3,62 & 1,43 \\
\hline & 3 & 12,81 & 15,47 & 12,50 & 4,82 & 3,89 & 4,05 & 2,77 & 3,80 & 1,46 \\
\hline & 4 & 10,96 & 15,37 & 13,80 & 0,00 & 3,14 & 4,22 & 2,71 & 3,95 & 0,00 \\
\hline & 5 & 10,68 & 15,79 & 14,20 & 6,09 & 3,39 & 4,89 & 3,36 & 4,50 & 1,93 \\
\hline & Média & 10,95 & 15,63 & 13,66 & 3,23 & 3,24 & 4,37 & 2,88 & 4,04 & 0,96 \\
\hline
\end{tabular}

* $\mathrm{F}_{\mathrm{M}}$ é a força máxima atingida pelo compósito

Nota-se que os resultados obtidos estão dentro dos intervalos fixados pela RILEM TC 162-TDF (2003) para as resistências residuais $f_{R, 1}$ e $f_{R, 4}$, que são 1 e $6 \mathrm{MPa}$ e 0 e $4 \mathrm{MPa}$, respectivamente. 
Os gráficos obtidos em todos os ensaios podem ser vistos abaixo (Figuras 3.11):

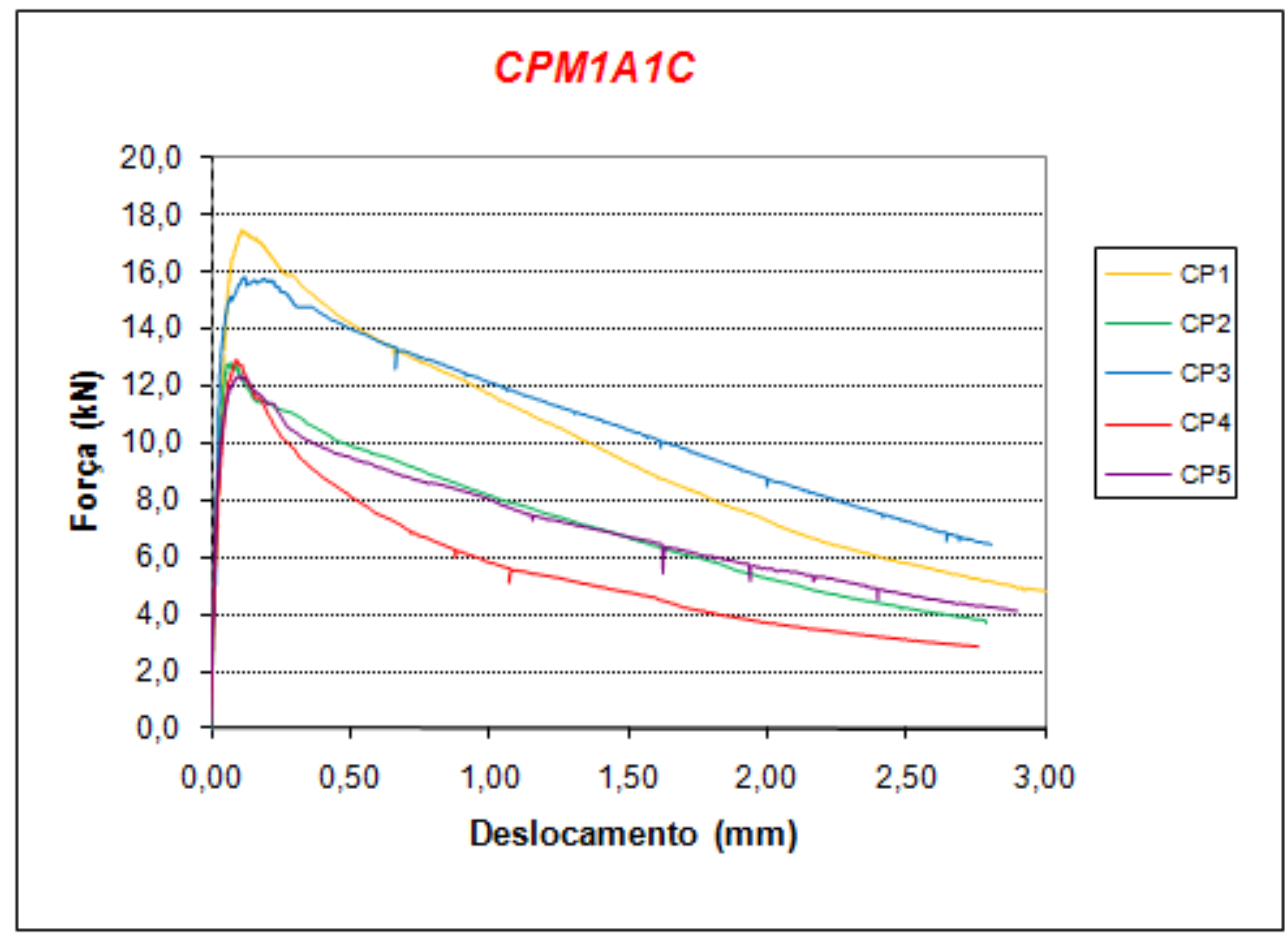

a) Compósito CPM1 $\mathrm{A} 1 \mathrm{C}$

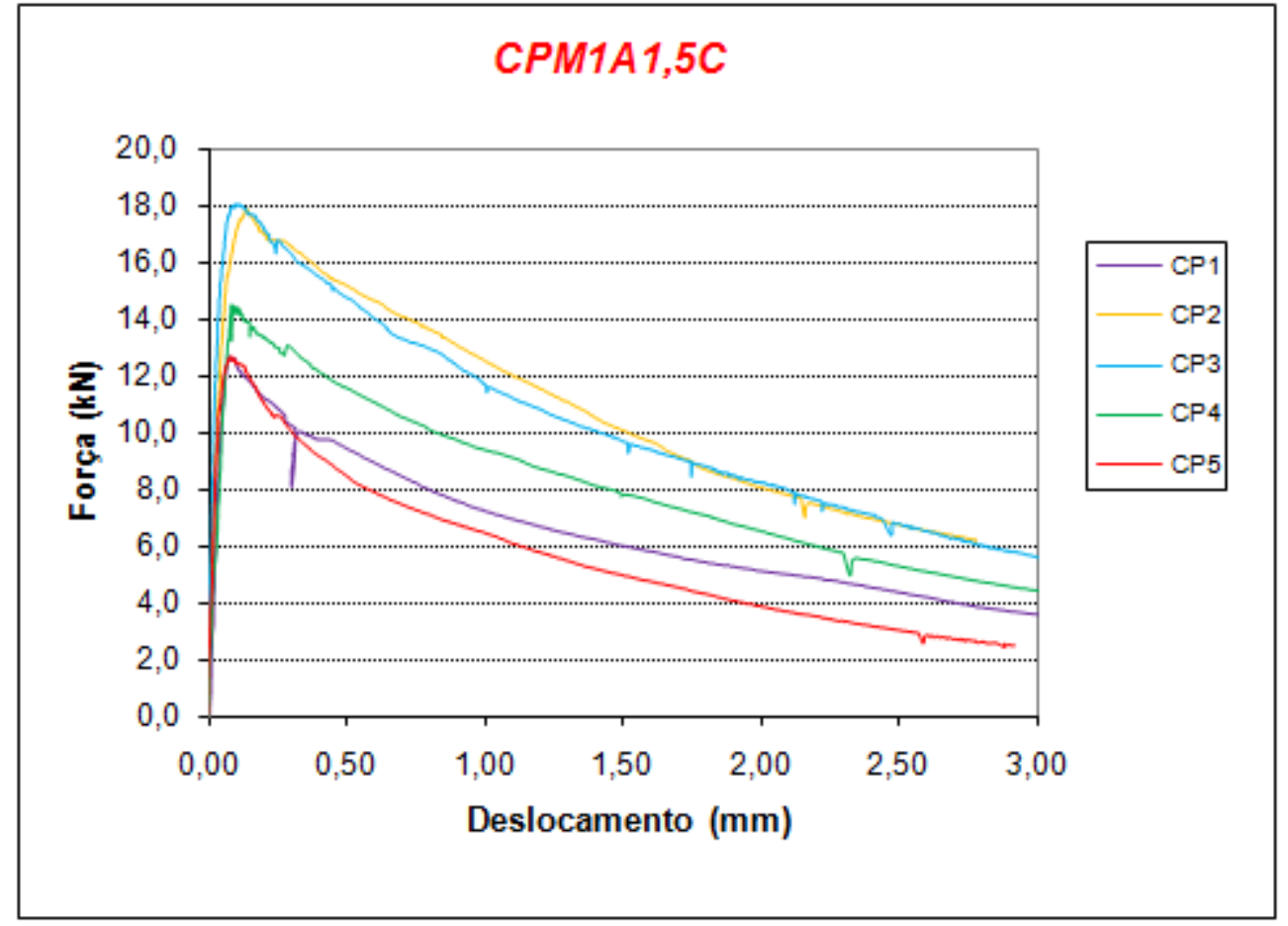

b) Compósito CPM1A1,5C 


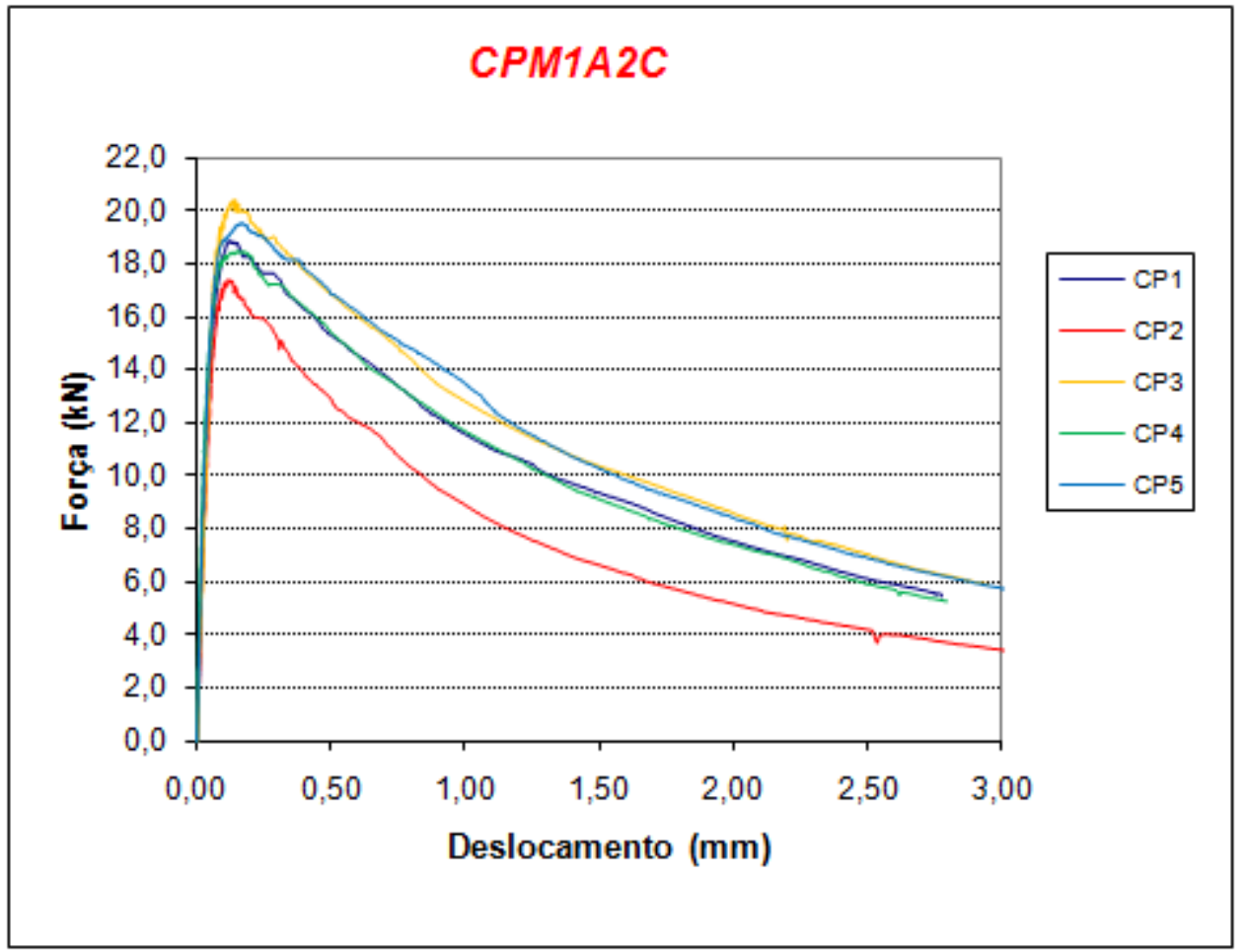

c) Compósito CPM1A2C

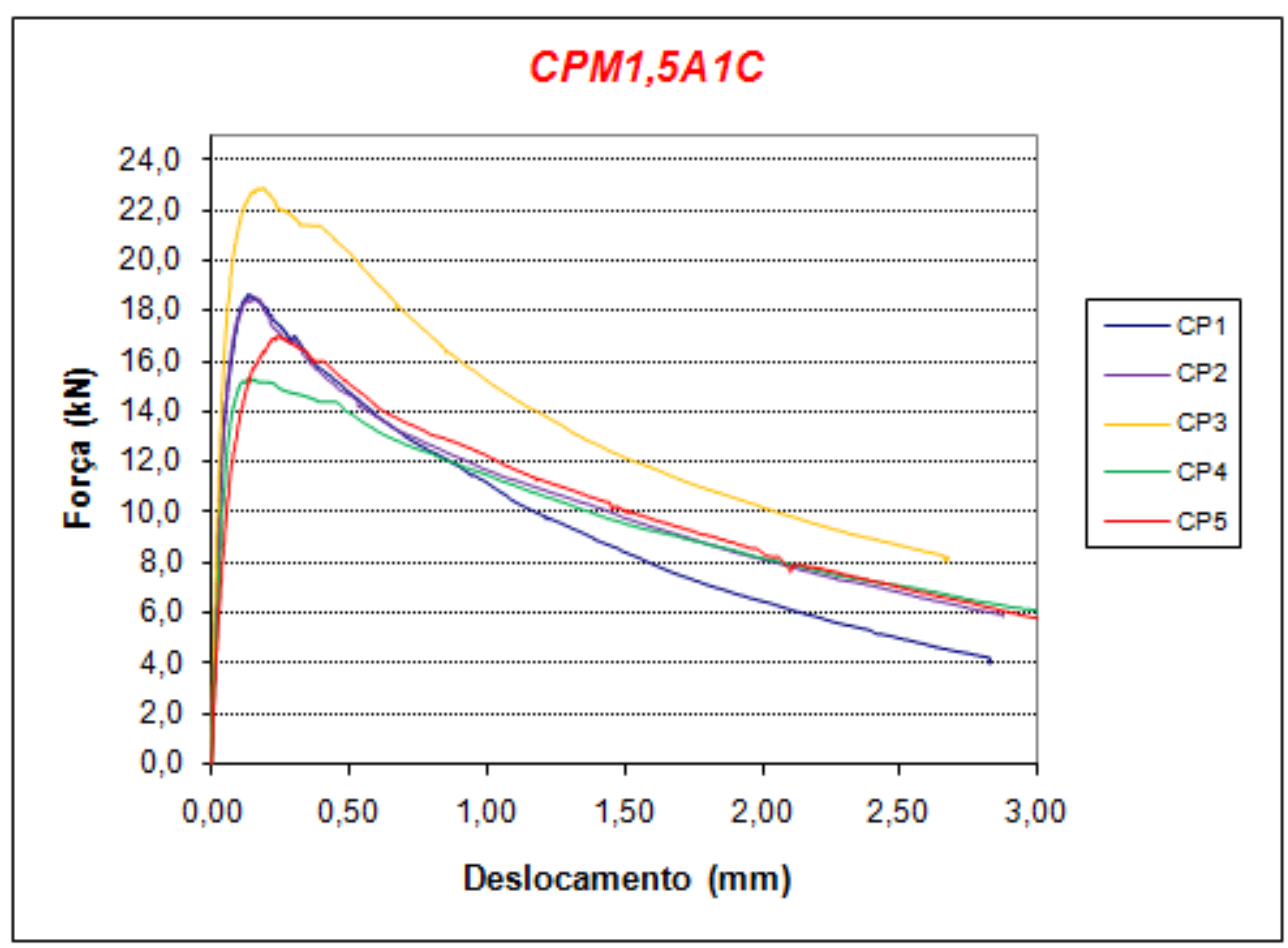

d) Compósito CPM1,5A1C 


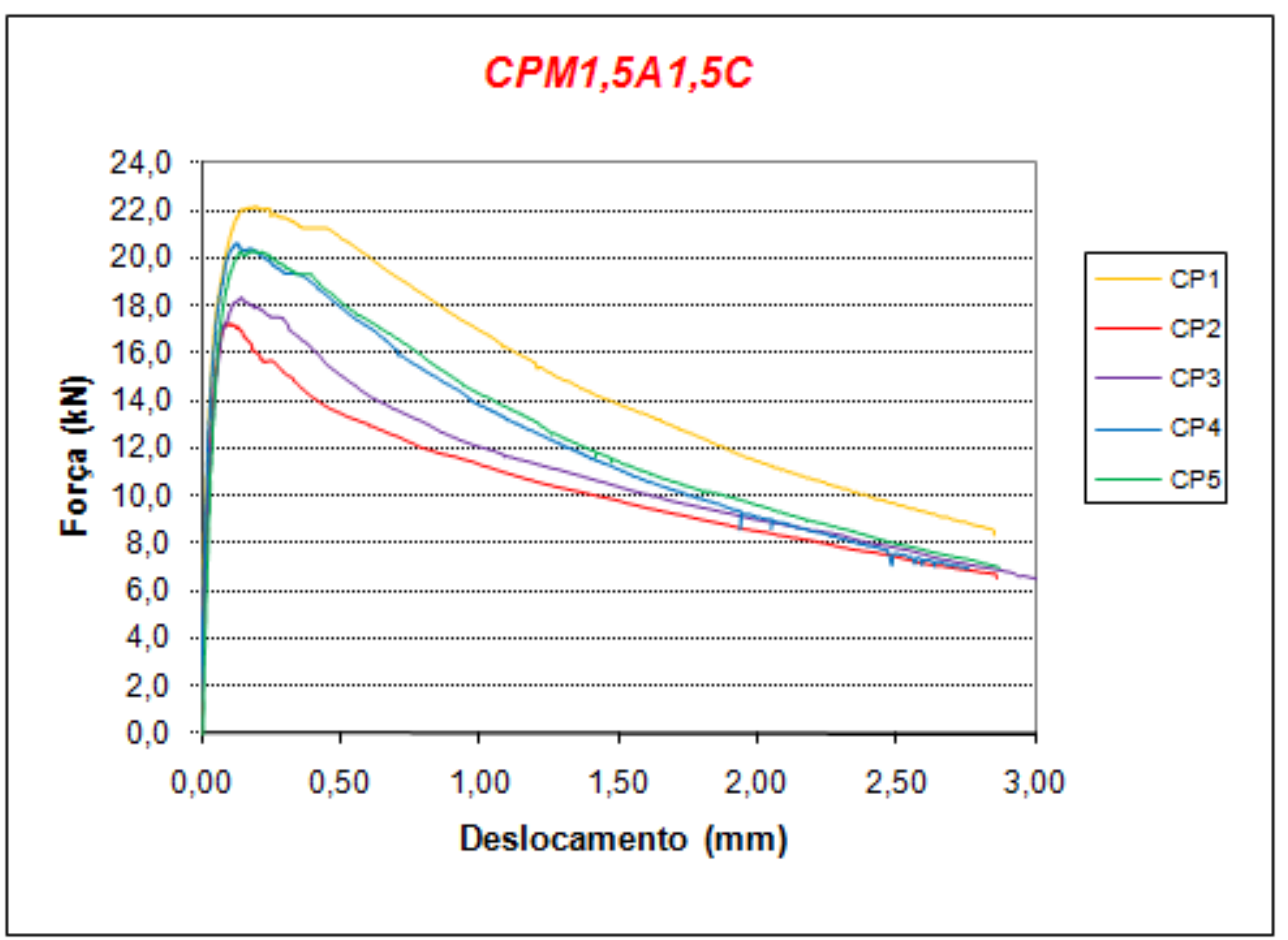

e) Compósito CPM1,5A1,5C

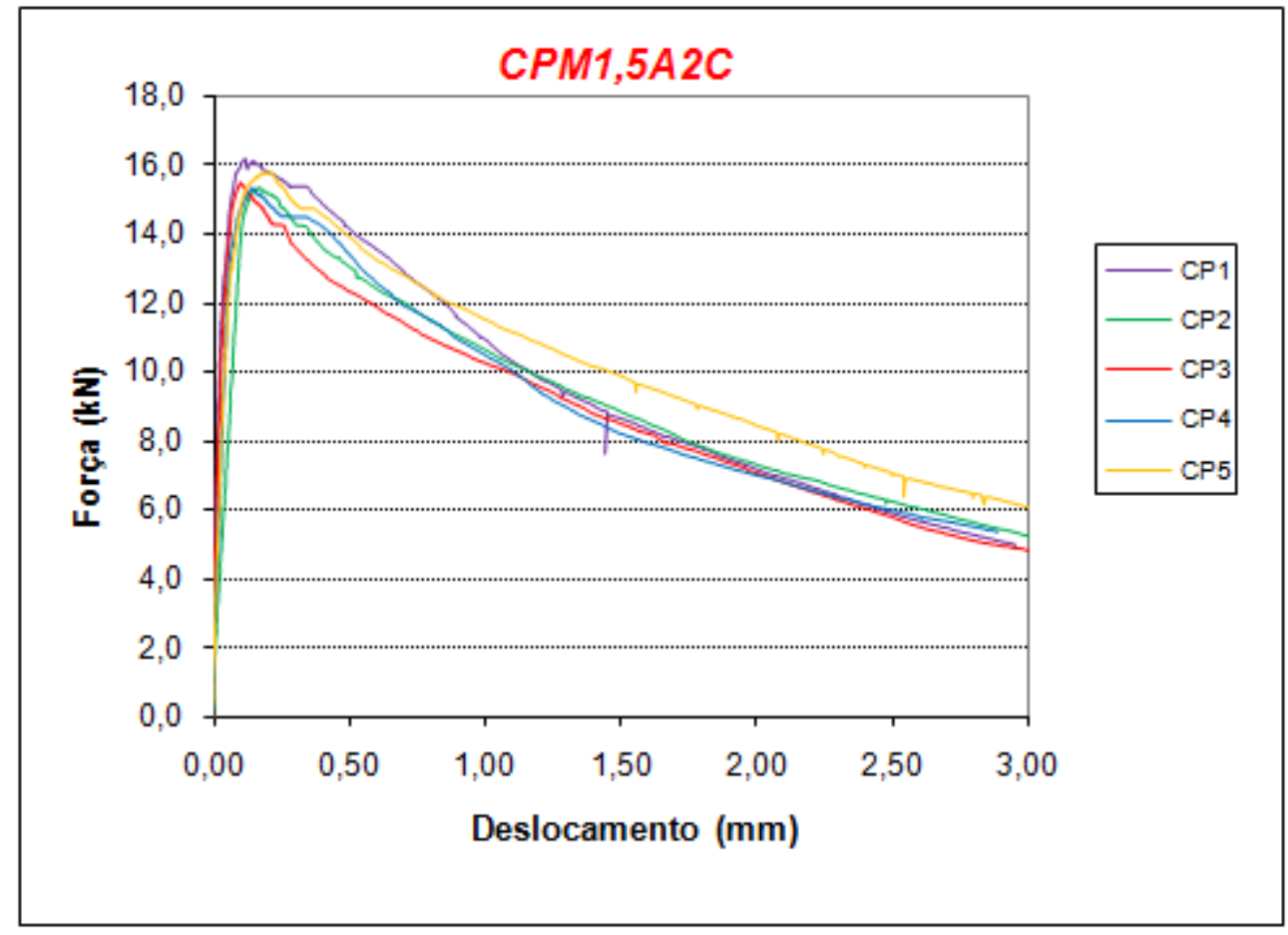

f) Compósito CPM1,5A2C

Figura 3.11 - Curvas força $x$ deslocamento vertical dos compósitos

Em todos os compósitos é possível observar uma grande variação nos resultados, principalmente até atingir a carga máxima (Figura 3.11). Depois, as curvas tendem a uma aproximação nos maiores valores de deslocamentos. Isso explica o grande número de corpos 
de prova exigidos pela RILEM TC 162-TDF (2002b). Os compósitos com maiores taxas de fibras (tipo A) apresentaram menor dispersão nos resultados.

Todos os compósitos apresentaram no gráfico um trecho inicial linear, onde o concreto apresentava-se íntegro e em seguida, após o pico de carga, apresentaram uma região não linear com perdas progressivas de carga (início das fissuras). Essa região ficou condicionada às propriedades inerentes à inserção de fibras e por isso, quanto menos brusca a perda de carga, maior a área abaixo do gráfico, consequentemente, maior a tenacidade do compósito.

Os compósitos que mais suportaram carga após o início da fissuração foram os CPM1A2C, CPM1,5A1C e CPM1,5A1,5C. Na Figura 3.12 são apresentadas as curvas força $x$ abertura da fissura (CMOD) para aberturas até $0,25 \mathrm{~mm}$, com o objetivo de melhorar a visualização do processo de transferência de tensões das microfibras (tipo C) e fibras (tipo A) para o concreto.

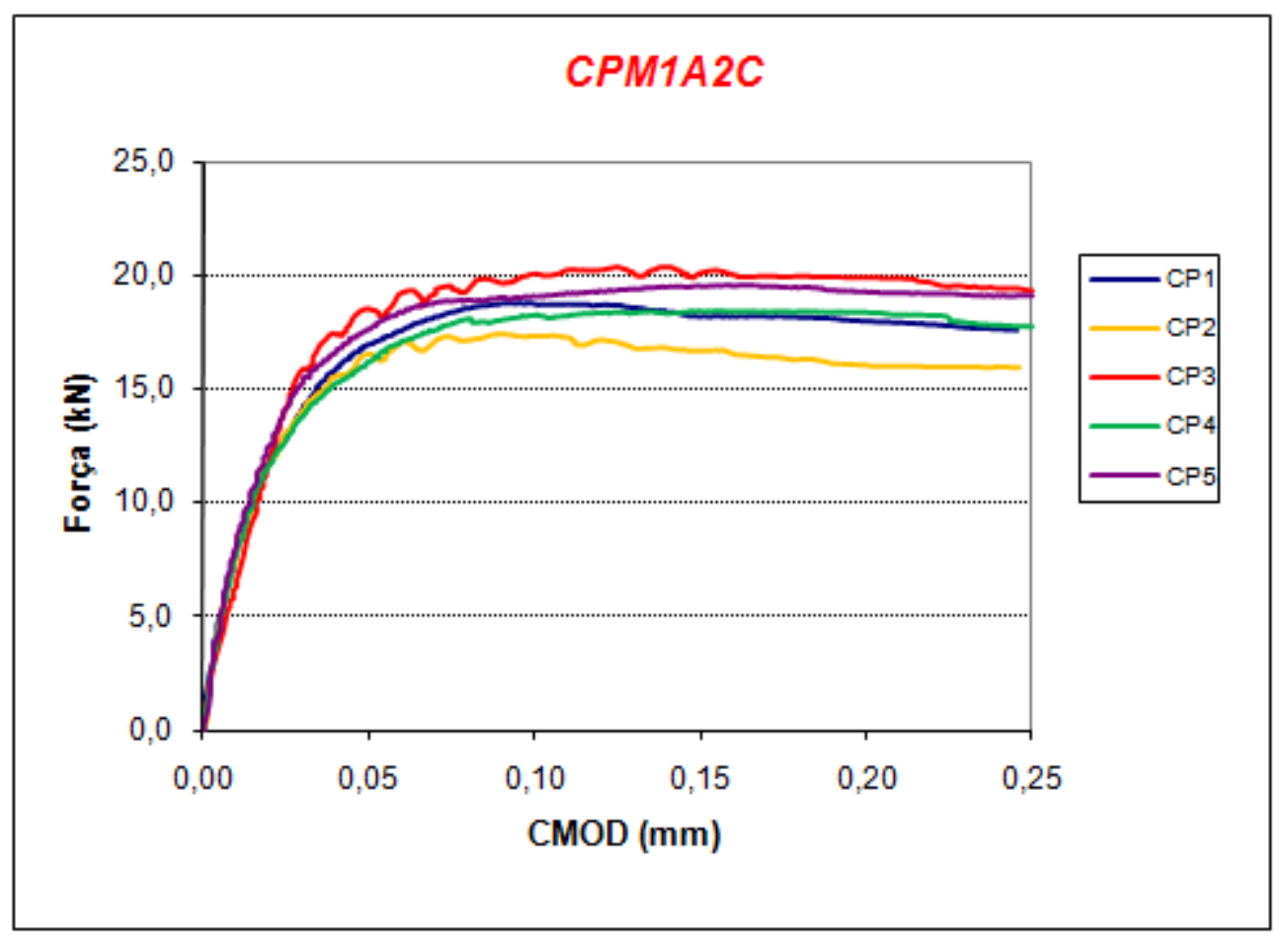

a) Compósito CPM1A2C 


\section{Capítulo 3 - Desenvolvimento do Compósito}

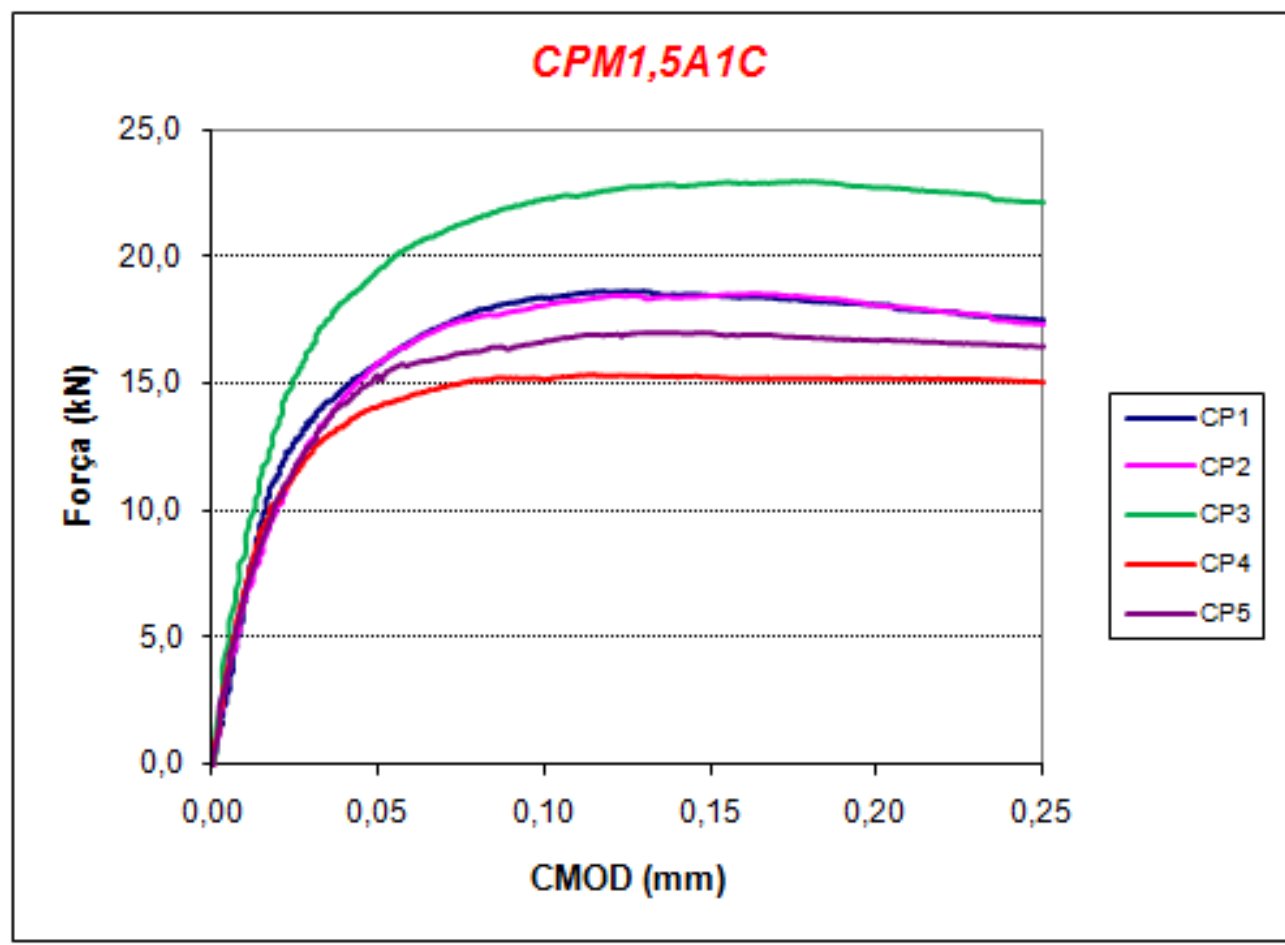

b) Compósito CPM1,5A1C

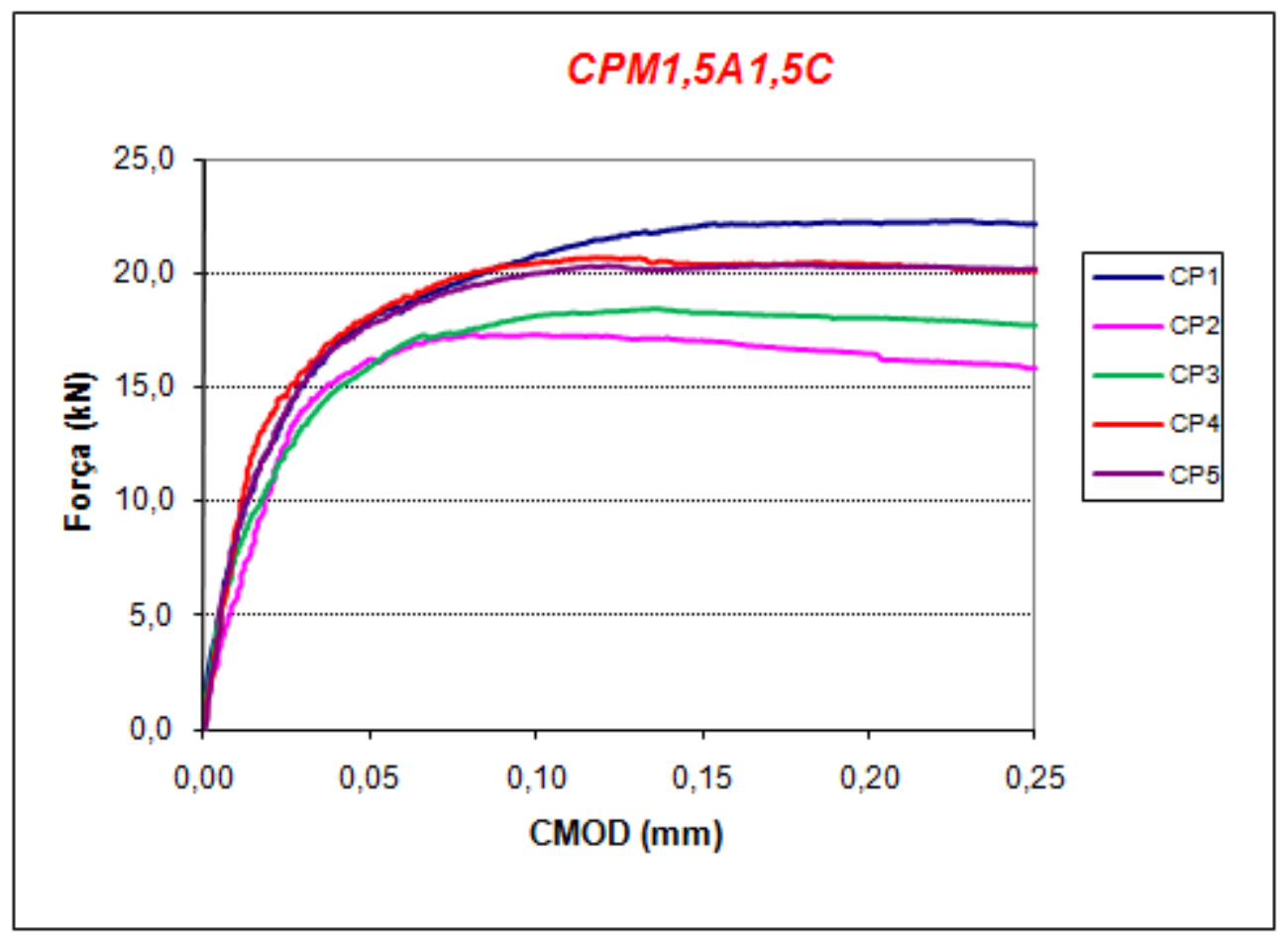

c) Compósito CPM1,5A1,5C

Figura 3.12 - Curvas força x abertura da fissura dos compósitos

O compósito CPM1A2C manteve a força máxima após o início da fissuração, passando por uma região turbulenta até atingir a estabilidade. O CPM1,5A1C teve 
comportamento semelhante, mas sem a região de instabilidade. Já o CPM1,5A1,5C esboçou até um aumento de carga após a fissuração. Nota-se que o início da fissuração é adiado com o aumento da taxa de microfibra (tipo C).

Na Figura 3.13 encontra-se uma comparação entre a força máxima resistida pelo concreto $\left(F_{M}\right)$ e a força máxima atingida no intervalo de deslocamento entre 0 e $0,05 \mathrm{~mm}$ $\left(F_{L}\right)$, que corresponde ao limite de proporcionalidade. Em todos os casos, a $F_{M}$ foi superior à $F_{L}$. Isso significa que para atingir a carga máxima houve uma deformação maior do corpo de prova, adentrando ao intervalo correspondente à parcela de contribuição das fibras. Em outras palavras, foram elas que proporcionaram o aumento da capacidade de carga do compósito. Observa-se que a força $F_{L}$, que delimita a contribuição da matriz, apresenta pequena variação entre os compósitos. O comportamento é o esperado já que todos os compósitos apresentam a mesma matriz. A diferença perdura na taxa de microfibras. Com exceção do compósito CPM1,5A2C, o aumento da taxa de microfibras, aumenta a força $F_{L}$. Em contrapartida, a força $F_{M}$, que já faz parte da contribuição das fibras, apresenta variação de até $38 \%$.

$\mathrm{O}$ aumento da $F_{M}$ em relação à $F_{L}$ foi maior para o compósito CPM1,5A1C, que obteve $44 \%$ de melhoria, mas a melhor resposta foi do CPM1,5A1,5C.

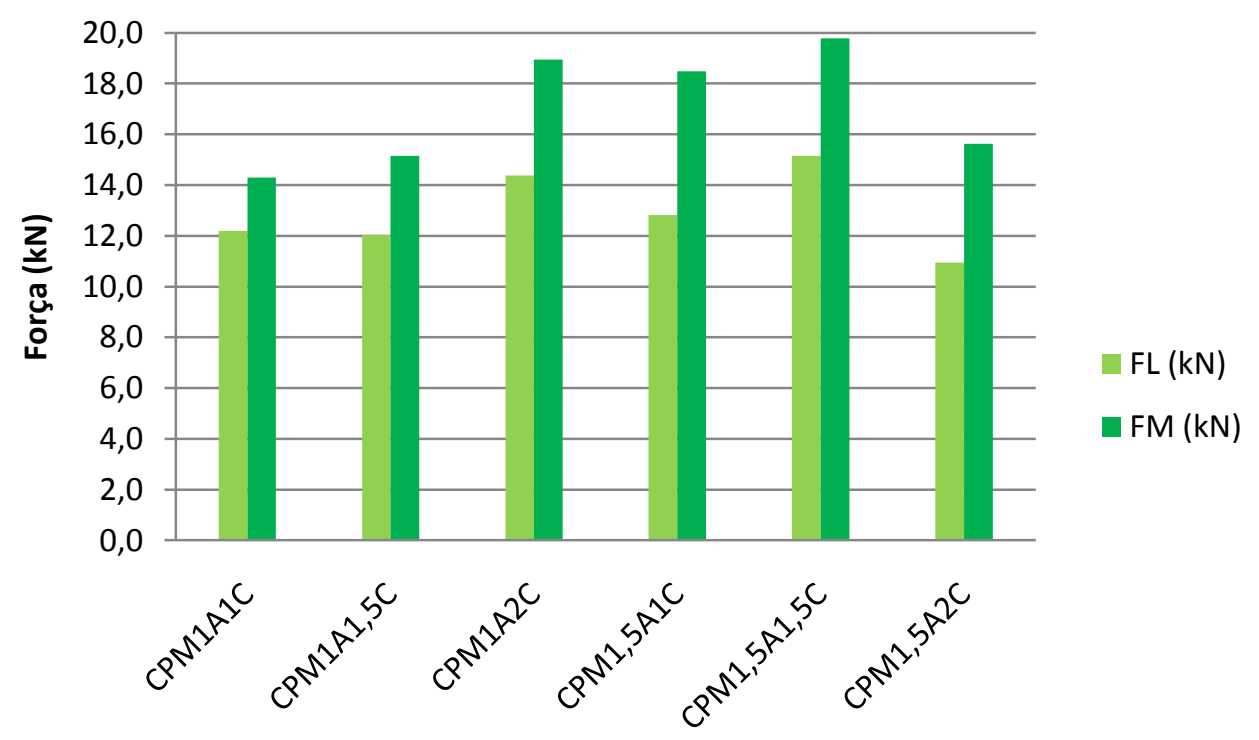

Figura 3.13 - Comparação entre as forças $F_{L}$ e $F_{M}$

No gráfico da Figura 3.14, são comparadas as resistências dos compósitos antes e após o limite de proporcionalidade até o ponto $\delta_{2}$. Assim como ocorreu com as forças, as tensões 
de flexão equivalente $\left(f_{e q, 2}\right)$ tiveram considerável aumento em relação às resistências da matriz cimentícia, com exceção do compósito CPM1A1C. Em geral, as resistências da matriz também obtiveram pouca variação, com seu aumento atrelado ao aumento da taxa de microfibras, com exceção do compósito CPM1,5A2C.

Com relação ao CPM1A1C, observa-se na Figura 3.11a que, para atingir a $F_{L}$ a viga teve de se deformar mais que as outras, aumentando a área correspondente à matriz cimentícia. Por isso, embora a força máxima tenha sido atingida com auxílio das fibras, a matriz cimentícia apresentou maior área abaixo do gráfico, consequentemente, maior resistência.

O aumento da $f_{e q, 2}$ em relação à $f_{f c t, L}$ chegou a $36 \%$ no compósito CPM1,5A1C, mas a tensão equivalente máxima foi obtida pelo compósito CPM1,5A1,5C.

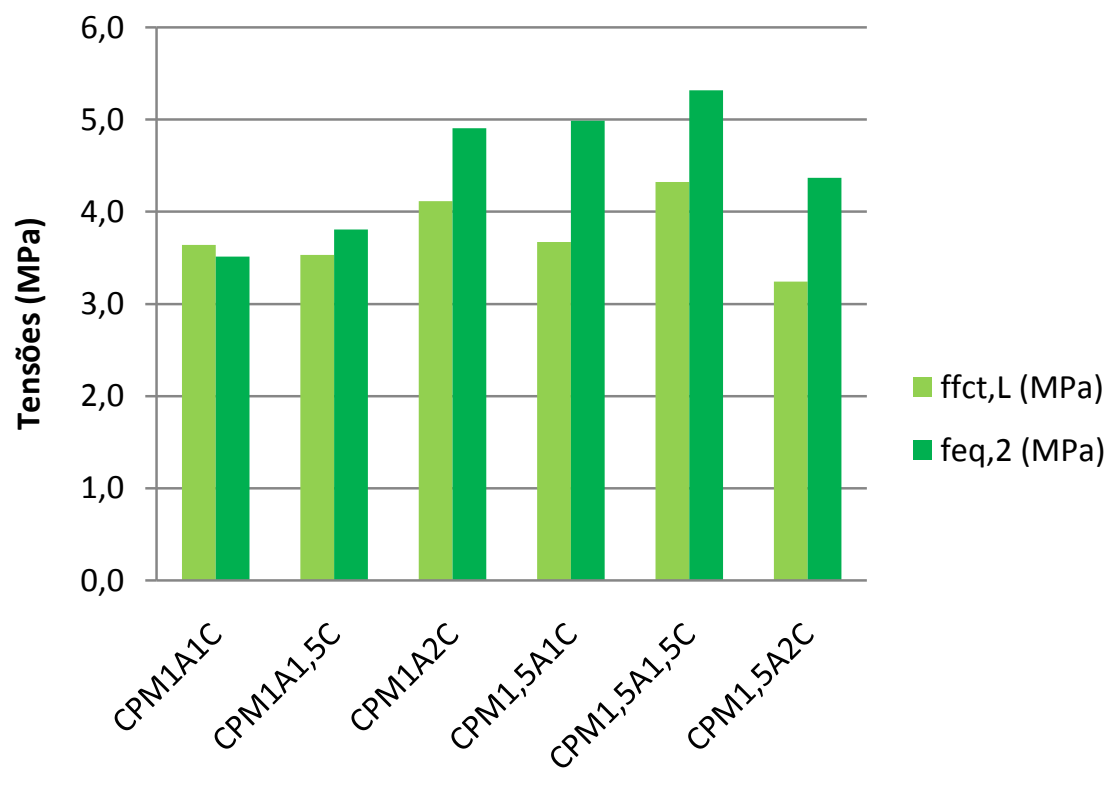

Figura 3.14 - Comparação entre as tensões $f_{f c t, L} \mathrm{e} f_{e q, 2}$

Esse fato comprova a eficiência da inserção de fibras (tipo A) e microfibras (tipo C) de aço ao concreto. O que não foi possível concluir através dos resultados desse trabalho foi que as microfibras (tipo C) auxiliaram no processo pré-fissuração do concreto, já que não houve ensaio sem a incorporação delas para comparação. Além disso, se adotar um valor fixo de microfibra (tipo C), observa-se que os valores das resistências à tração na flexão também melhoram com o aumento da taxa de fibra (tipo A). Mas, essa resposta pode ser trazida do 
trabalho de Ferrari (2007) que comprovou que a inserção apenas da fibra (tipo A) ao concreto reduziu os valores das resistências das matrizes quando comparados aos do concreto convencional (CPM). Por outro lado, ao associar a microfibra (tipo C), os traços CPM1A1C e CPM1A2C aumentaram suas resistências à tração na flexão em 28\% e 37\% respectivamente, comparadas às resistências do concreto convencional (CPM).

Utilizando o valor de tensão de flexão equivalente $f_{e q, 3}$ para analisar a área abaixo do gráfico no deslocamento mais avançado $\left(\delta_{3}\right)$, obteve-se a seguinte resposta (Figura 3.15):

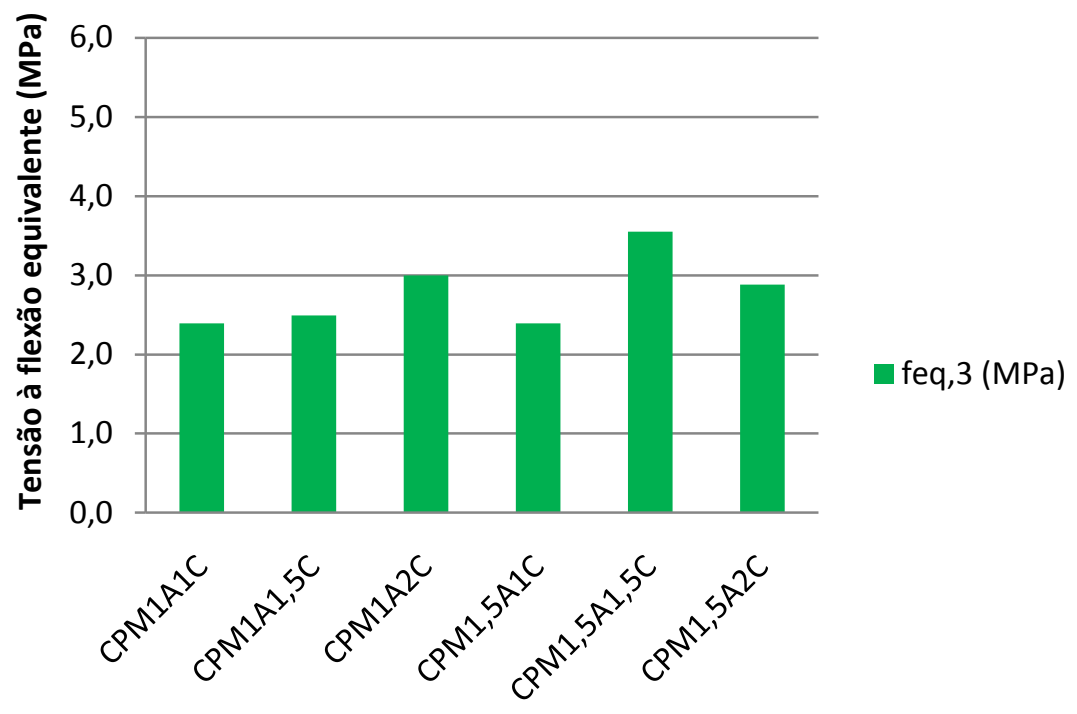

Figura 3.15 - Análise dos valores de tensão de flexão equivalente $f_{q e, 3}$

O compósito de maior tenacidade, ou com maior energia absorvida até ponto $\delta_{3}$, foi o CPM1,5A1,5C, seguido do CPM1A2C. Isso demonstra que, para uma maior deformação, ele é o compósito mais resistente. O fato torna-se interessante quando o objetivo é produzir uma viga reforçada com característica mais dúctil, capaz de se deformar sem desprender o laminado através da formação de fissuras. Em média, os compósitos com maior taxa de fibra (tipo A) apresentaram os maiores valores de $f_{e q, 3}$, indicando que as fibras corresponderam às expectativas.

Comparando as tensões residuais $f_{R, 1}$ e $f_{R, 4}$ dos compósitos, ou seja, as tensões correspondentes aos deslocamentos verticais pré-determinados e iguais a $0,46 \mathrm{~mm}$ e $3,0 \mathrm{~mm}$ respectivamente, tem-se a seguinte situação (Figura 3.16): 


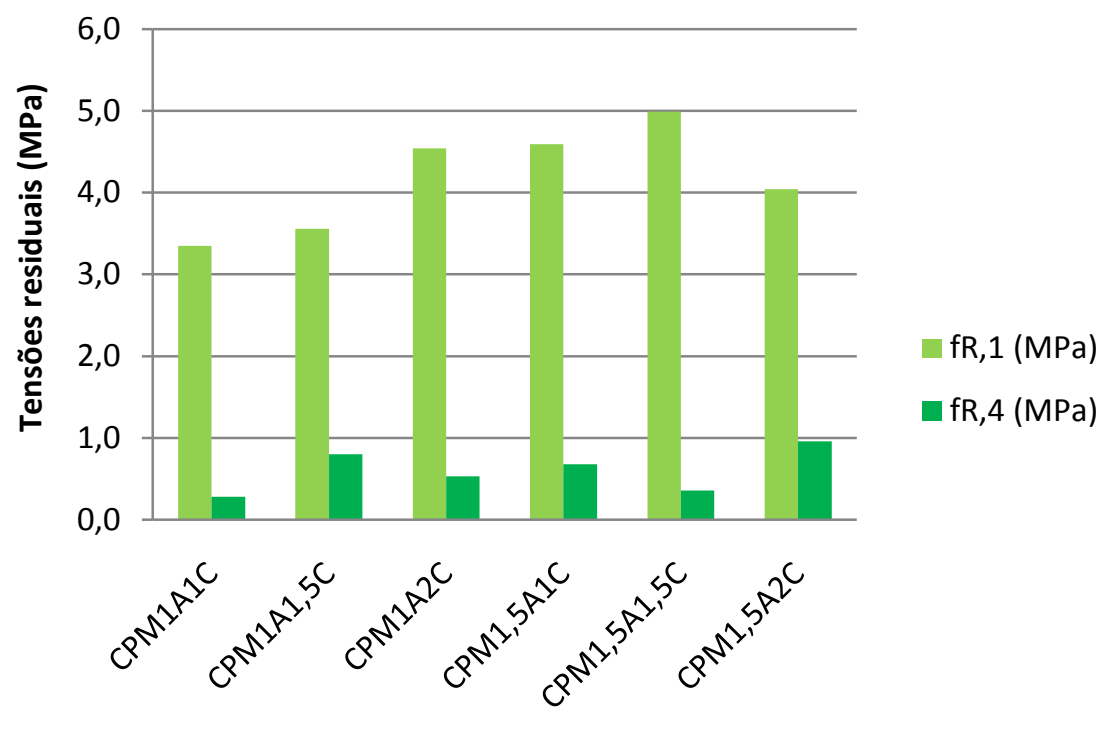

Figura 3.16 - Comparação entre as tensões residuais

As tensões residuais estão relacionadas às forças e não às áreas, como acontece com as tensões equivalentes. Para o menor deslocamento vertical $\left(\delta_{R, 1}=0,46 \mathrm{~mm}\right)$, o que ocorre, geralmente, é que a força correspondente fica localizada entre o limite de proporcionalidade e a força máxima. Por isso, o comportamento dos resultados apresentados aqui é semelhante ao comportamento apresentado na Figura 3.13. Na região onde se localiza o ponto $\delta_{R, 1}=0,46$ mm, já houve o início de fissuração, por isso quanto maior a taxa de fibra (tipo A), maior a força resistida. A exceção ficou por conta do CPM1,5A2C. Novamente a melhor resposta foi do compósito CPM1,5A1,5C, seguido dos compósitos CPM1,5A1C e CPM1A2C.

Já a tensão residual no ponto com maior deslocamento vertical $\left(\delta_{R, 4}=3,0 \mathrm{~mm}\right)$, representa a força resistida pela viga em seu processo mais avançado de fissuração, com abertura do entalhe igual a 3,5 mm. Nesse caso, todos os compósitos apresentaram tensões reduzidas, com destaque apenas para o CPM1,5A2C, seguido pelo CPM1,5A1C.

\subsection{Conclusão}

Diante dos resultados, foi perceptível que o concreto com as melhores respostas ao objetivo proposto foi o compósito CPM1,5A1,5C. A inserção de fibras proporcionou tanto o aumento da carga $F_{M}$ quanto de resistência para os deslocamentos $\delta_{2}$ e $\delta_{3}$. A inserção das microfibras, por sua vez, condicional o compósito a obter maior resistência antes do limite de 
proporcionalidade, ou seja, melhorou a característica da matriz cimentícia em resposta ao esforço de tração na flexão.

O problema é que, além de apresentar menor trabalhabilidade, o compósito possui uma taxa de microfibras igual a 1,5\%, lembrando que o consumo desse material é um fator limitador da pesquisa, dada a dificuldade de fornecimento. A questão da trabalhabilidade do CPM1,5A1,5C poderia ser facilmente resolvida com o aumento da adição de superplastificante. Mas na tentativa de prevenir o problema da falta de microfibras para o ensaio final, optou-se em adotar o compósito CPM1,5A1C, também com resultados satisfatórios, porém com menor consumo de microfibras e melhor trabalhabilidade. 
Nessa etapa do trabalho, propõe-se estudar o conjunto concreto-resina-laminado. O bom desempenho da técnica de inserção do laminado no concreto de cobrimento depende do conhecimento da transferência de forças do laminado para o concreto. Por isso, a falha de qualquer um desses componentes pode prejudicar o sistema levando a falência do reforço à viga. Além do mais, é necessário caracterizar e quantificar a mobilização de esforços no laminado, como parte do estudo de sua ancoragem no substrato de concreto reforçado com fibras de aço.

Com esse objetivo, buscou-se um ensaio que permitisse a análise das interfaces dos materiais, gerando resultados em termos de tensão no laminado versus deslizamento. Como não há um ensaio regulamentado para a análise da ancoragem do laminado, optou-se por realizar o ensaio de aderência proposto por Cruz e Barros (2003), que é uma adaptação da proposta da RILEM para a caracterização da ligação de armaduras convencionais ao concreto (RILEM, 1982). Essa escolha foi fundamentada pela qualidade dos resultados obtidos em trabalhos anteriores, como de Fonseca (2007), pela experiência adquirida pelo laboratório, além da facilidade de montagem do ensaio.

Com exceção da resina, os demais materiais foram ensaiados individualmente seguindo normas específicas, e por fim, ensaiados em conjunto.

\subsection{Configuração do ensaio}

A Figura 4.1 mostra a configuração do ensaio, que consiste basicamente em dois blocos de concreto não armado reforçados com fibras de aço, unidos na parte superior por uma rótula metálica e na parte inferior pelo laminado. 


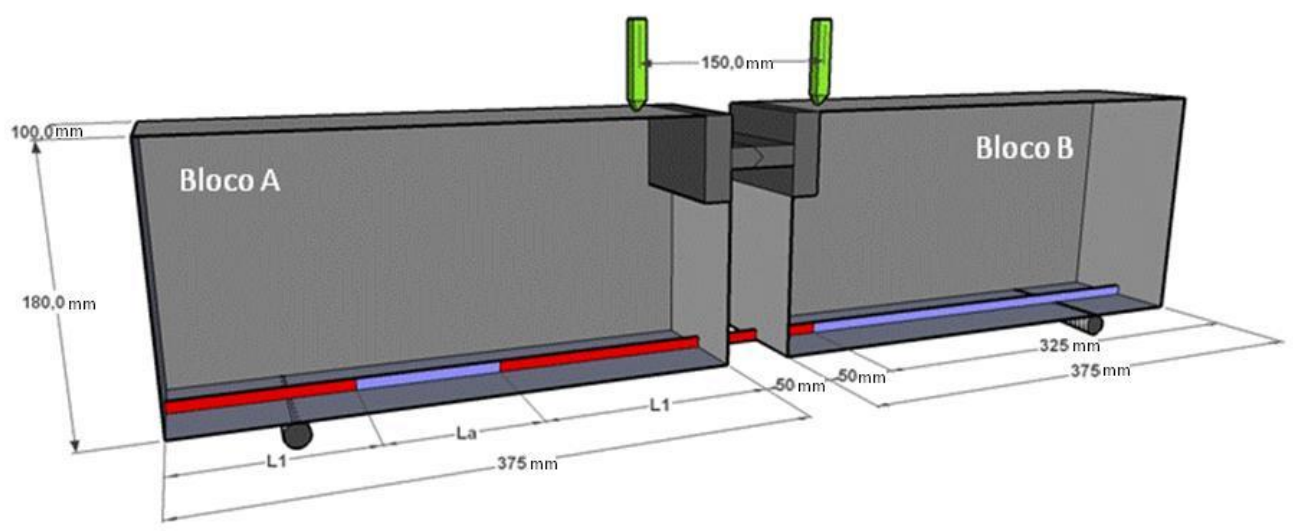

Figura 4.1 - Esquema do ensaio de aderência proposto por Cruz e Barros (2003)

Do trabalho de Cruz e Barros (2003), já se sabe que o bloco de concreto reforçado com fibras resiste ao ensaio sem necessidade de armação. Dessa forma, utilizou-se o compósito cimentício desenvolvido no Capítulo 3 com o objetivo de refinar o estudo de suas propriedades do concreto e observar seu comportamento mediante a tração do laminado.

$\mathrm{O}$ ensaio restringiu-se ao bloco $\mathrm{A}$, onde variou o comprimento de ancoragem do laminado $\left(\mathrm{L}_{\mathrm{a}}\right)$, enquanto que no bloco $\mathrm{B}$, o laminado teve comprimento de ancoragem constante $(325 \mathrm{~mm})$, suficiente para que não houvesse deslizamento.

Foram testados três comprimentos de ancoragem: 70, 140 e $210 \mathrm{~mm}$, sendo confeccionados dois modelos para cada comprimento. Suas nomenclaturas ficam assim designadas: MxLAy onde $\underline{x}$ é o número do modelo (1 ou 2) e $\underline{y}$ o comprimento de ancoragem (Tabela 4.1).

Tabela 4.1 - Nomenclatura dos modelos

\begin{tabular}{c|c|c}
\hline $\begin{array}{c}\text { Comprimento de } \\
\text { Ancoragem }(\mathbf{m m})\end{array}$ & Modelo & Nomenclatura \\
\hline 70 & 1 & M1LA70 \\
\cline { 2 - 3 } & 2 & M2LA70 \\
\hline \multirow{2}{*}{140} & 1 & M1LA140 \\
\cline { 2 - 3 } & 2 & M2LA140 \\
\hline 210 & 1 & M1LA210 \\
\cline { 2 - 3 } & 2 & M2LA210 \\
\hline
\end{tabular}




\subsection{Caracterização dos materiais}

\subsubsection{Concreto}

O concreto utilizado para a confecção dos modelos foi aquele desenvolvido no Capítulo 3, ou seja:

Tabela 4.2 - Consumo de material utilizado para modelagem dos blocos e corpos de prova

$$
\text { Traço= } 1: 2,30: 1,70: 0,48
$$

\begin{tabular}{c|c}
\hline Material & Consumo $\left(\mathbf{k g} / \mathbf{m}^{\mathbf{3}}\right)$ \\
\hline Cimento CPV ARI & 443,0 \\
\hline Areia & 1018,9 \\
\hline Brita 0 & 753,1 \\
\hline Água & 212,6 \\
\hline Fibra de Aço FS8 Wirand & $11,5 \mathrm{~kg}^{*}$ \\
\hline Microfibra de Aço & $7,7 \mathrm{~kg}^{*}$ \\
\hline Superplastificante Glenium 51 & $0,22 \mathrm{~kg}^{*}$
\end{tabular}

*Quantidade utilizada para confecção dos modelos.

No misturador foram colocadas areia, brita e realizada uma mistura rápida. Em seguida, acrescentou-se o cimento, parte da água, e novamente procedeu-se a mistura. $\mathrm{O}$ restante da água foi adicionado durante o movimento do misturador, que em seguida recebeu as fibras e microfibras de aço. Por último adicionou-se o superplastificante e a mistura perdurou por mais três minutos. Vale ressaltar que essa sequência foi a que trouxe melhores resultados em termos de resistência e trabalhabilidade do concreto, como comentado no capítulo anterior. 


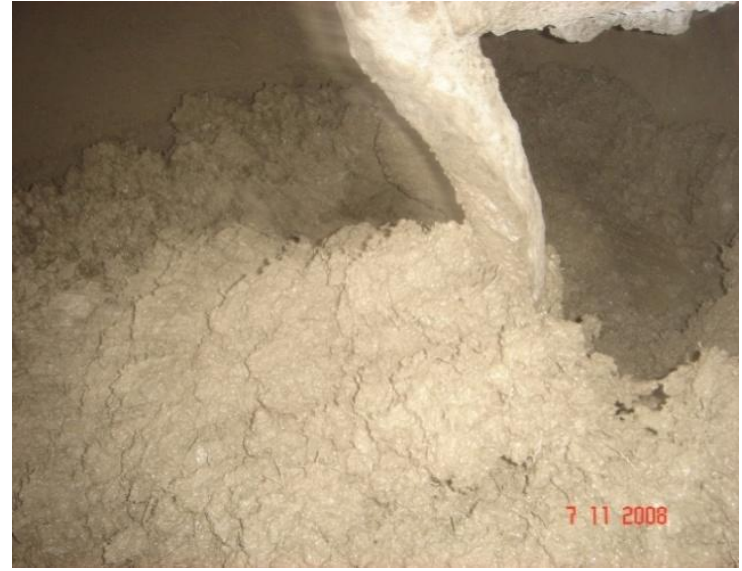

a) aspecto do concreto antes do uso de superplastificante

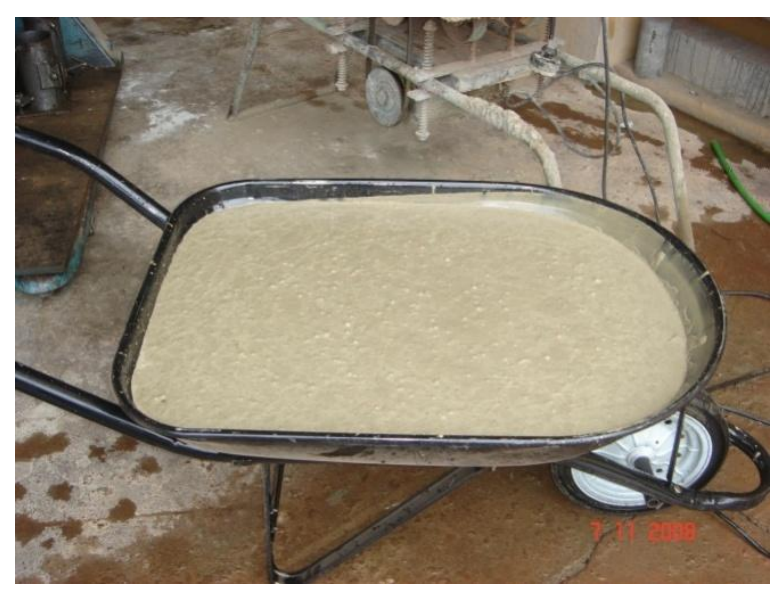

c) fluidez do concreto

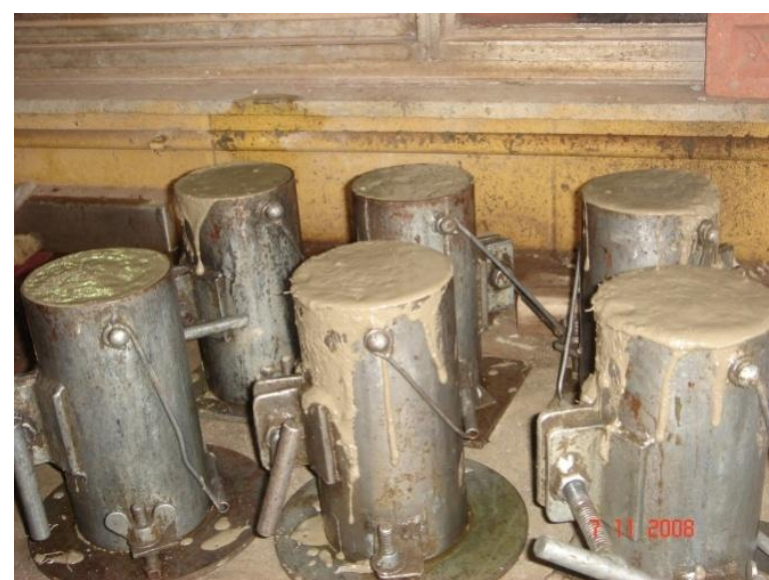

e) corpos de prova $10 \times 20 \mathrm{~cm}$

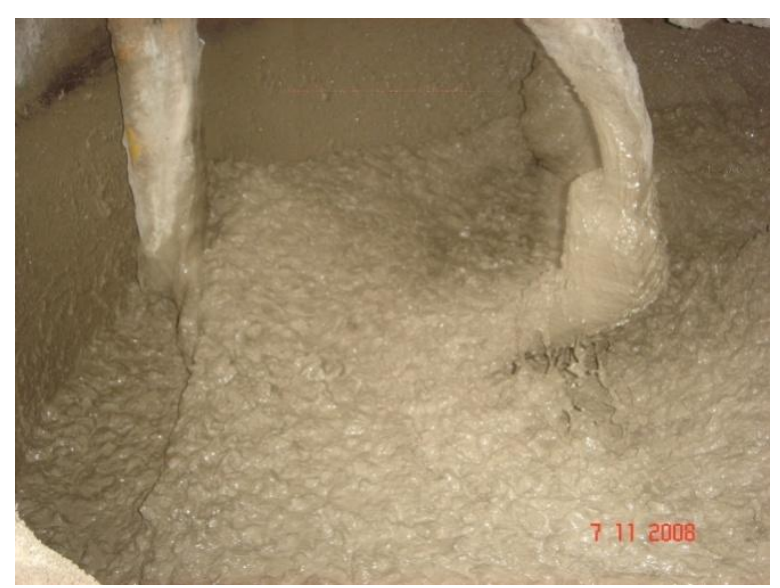

b) aspecto do concreto após o uso de superplastificante

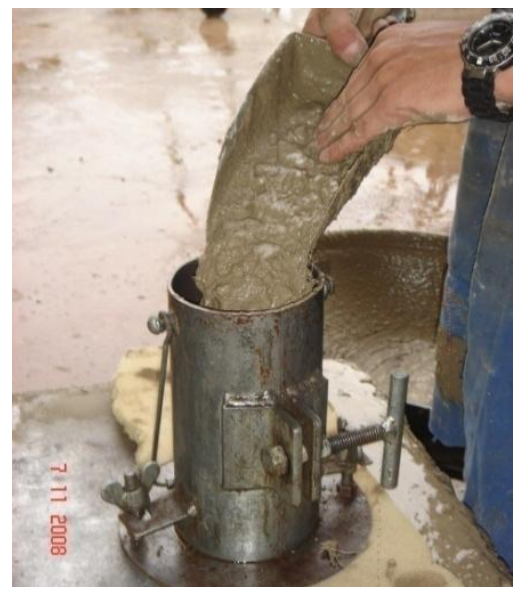

d) moldagem dos corpos de prova

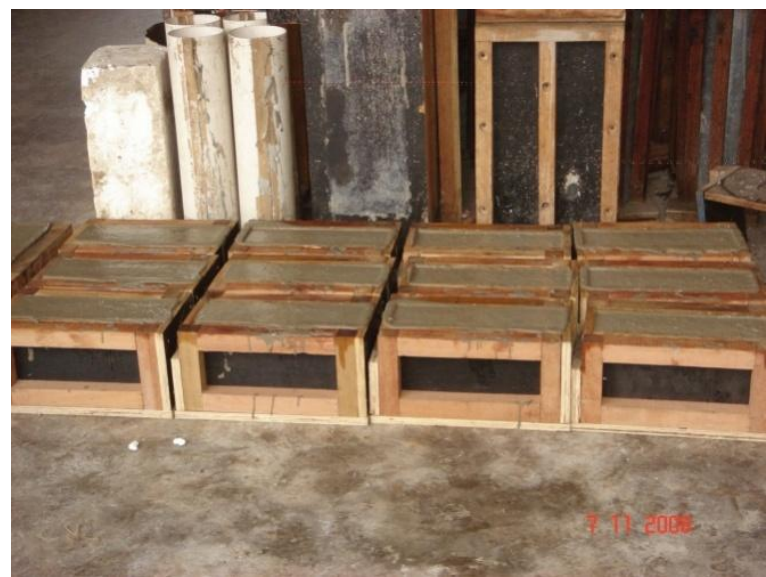

f) blocos de concreto

Figura 4.2 - Processo desde a mistura do concreto até a moldagem dos blocos

Tanto os corpos de prova cilíndricos quanto os blocos de concreto, foram vibrados em mesa vibratória por no máximo três segundos para que houvesse a compactação do concreto sem a orientação preferencial das fibras de aço. Apenas para constar, as fôrmas de madeira foram molhadas antes de receber o concreto evitando a absorção da água de hidratação. 
Por fim, vinte e quatro horas após a concretagem, os corpos de prova e os blocos foram retirados das formas e levados para a câmara úmida, onde permaneceram até a data do ensaio. Treze dias depois, os corpos cilíndricos foram testados à compressão e à tração de acordo com as normas ABNT NBR 5739 (1994) e ABNT NBR 7222 (1994), respectivamente, e os resultados encontram-se na Tabela 4.3:

Tabela 4.3 - Resultados da caracterização do concreto à compressão e à tração

\begin{tabular}{c|c|c}
\hline Corpo de Prova & $\mathbf{f}_{\mathbf{c}}(\mathbf{M P a})$ & $\mathbf{f}_{\mathbf{t}}(\mathbf{M P a})$ \\
\hline 1 & 32,45 & 2,99 \\
\hline 2 & 30,74 & 3,54 \\
\hline 3 & 32,74 & 3,56 \\
\hline Média & $\mathbf{3 1 , 9 8}$ & $\mathbf{3 , 3 6}$ \\
\hline
\end{tabular}

\subsubsection{Laminado}

O laminado de fibra de carbono foi comprado na empresa Rogertec-Rogermat, que comercializa o produto pelo nome de Fita MFC. Os dados do produto podem ser encontrados no site da empresa e estão apresentados na Tabela 4.4:

Tabela 4.4 - Propriedades físicas do laminado fornecidas pelo fabricante

\begin{tabular}{c|c|c|c|c|c}
\hline \multicolumn{2}{c|}{$\begin{array}{c}\text { Dimensão } \\
\text { mm }\end{array}$} & Área & $\begin{array}{c}\text { Resistência } \\
\text { à tração }\end{array}$ & $\begin{array}{c}\text { Módulo de } \\
\text { elasticidade }\end{array}$ & $\begin{array}{c}\text { Deformação } \\
\text { última }\end{array}$ \\
\cline { 1 - 2 } Largura & Espessura & $\mathbf{m m}^{\mathbf{2}}$ & $\mathbf{M P a}$ & $\mathbf{G P a}$ & \\
\hline 16 & 2 & 32 & 2068 & 131 & 0,017 \\
\hline
\end{tabular}

Cada item da tabela foi verificado, iniciando pelas dimensões. Com auxílio de um paquímetro digital foram recolhidas, de forma aleatória, vinte medidas de largura e espessura em uma amostra representativa do laminado.

Já o ensaio de caracterização, foi baseado na ASTM D3039/D 3039M (2008), que determina as propriedades de polímeros reforçados com fibras de alto módulo, contínuas ou não, posicionadas comportadamente e simetricamente à direção do ensaio. 
Foram preparadas três amostras com um metro de comprimento cada, limpas com álcool isopropílico e fixados extensômetros elétricos com $5 \mathrm{~mm}$ de campo posicionados no meio de seus comprimentos. Também foi utilizado extensômetro removível na outra face do laminado como mostra a Figura 4.3.

A ASTM D3039/D 3039M (2008), recomenda o uso de tiras (tabs) nas extremidades dos laminados para que a aplicação da força seja bem sucedida e previna falhas prematuras no modelo, como o esmagamento da região pela prensa da máquina de ensaio. Essa recomendação é reforçada quando se trata de materiais unidirecionais, como é o caso. Por isso, foram criadas tiras com $15 \mathrm{~cm}$ de comprimento do mesmo material, fixadas ao laminado com cola instantânea. A recomendação da norma em relação à cola é de que ela possua um elevado alongamento e que seja aplicada de forma retilínea e uniforme, evitando uma indesejável concentração de tensões. O uso de resina para essa fixação foi descartado porque no ensaio de Fonseca (2007), houve deslizamentos entre as tiras e o laminado, prejudicando o resultado final.

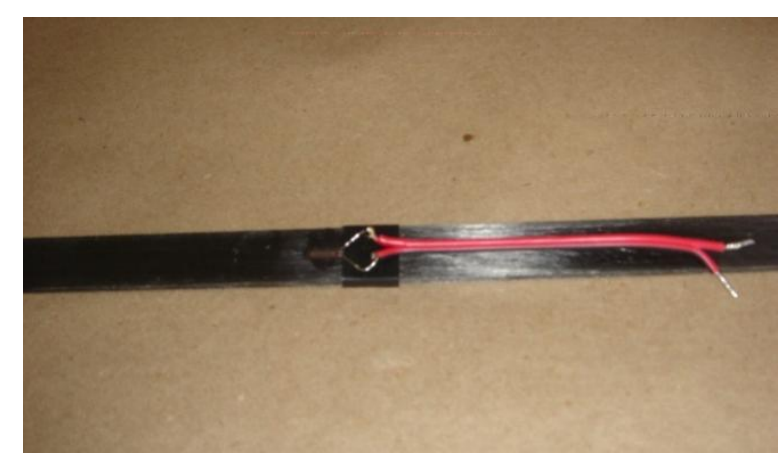

a) extensômetro fixado no laminado

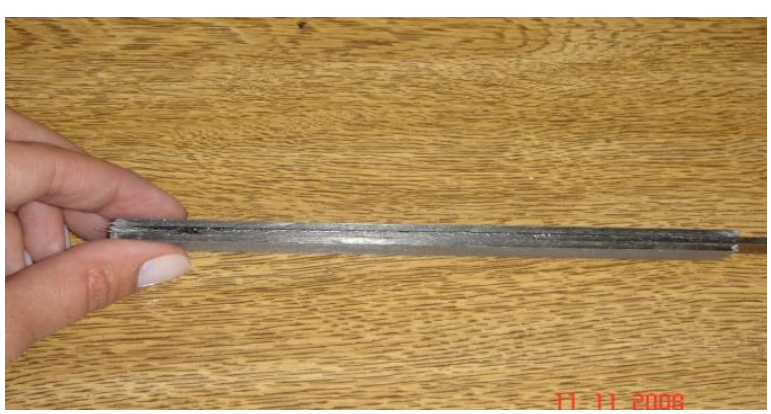

b) detalhe da aba na extremidade do laminado

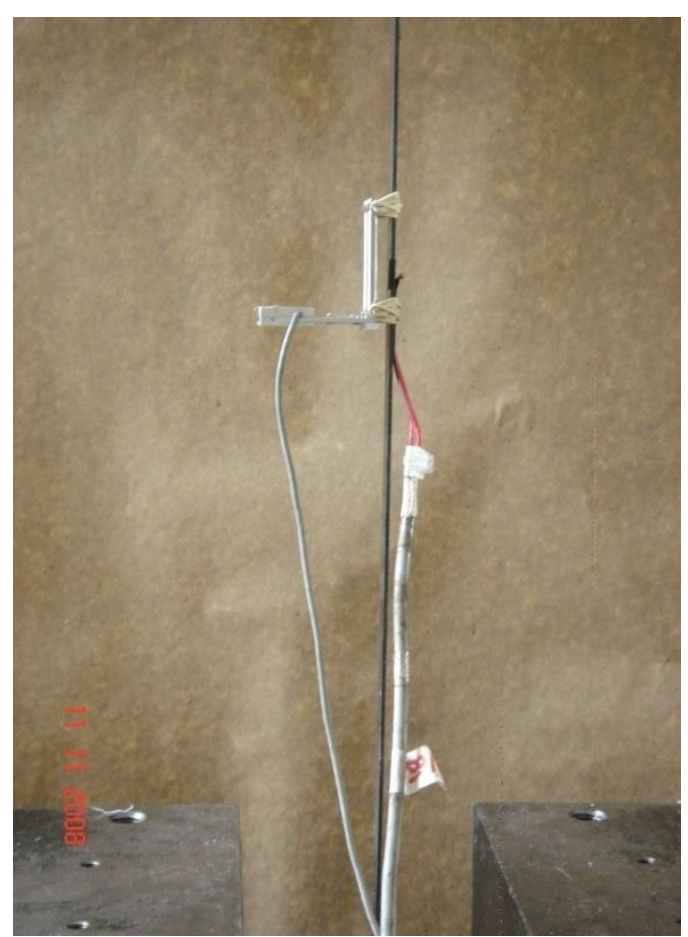

c) esquema do ensaio com extensômetro removível

Figura 4.3 - Detalhes do ensaio de caracterização do laminado 
Os ensaios foram realizados na máquina universal servo-hidráulica da marca Instron com sistema de aquisição de dados System 5000 da marca Vishay, e o aspecto final dos laminados foi o seguinte (Figura 4.4):

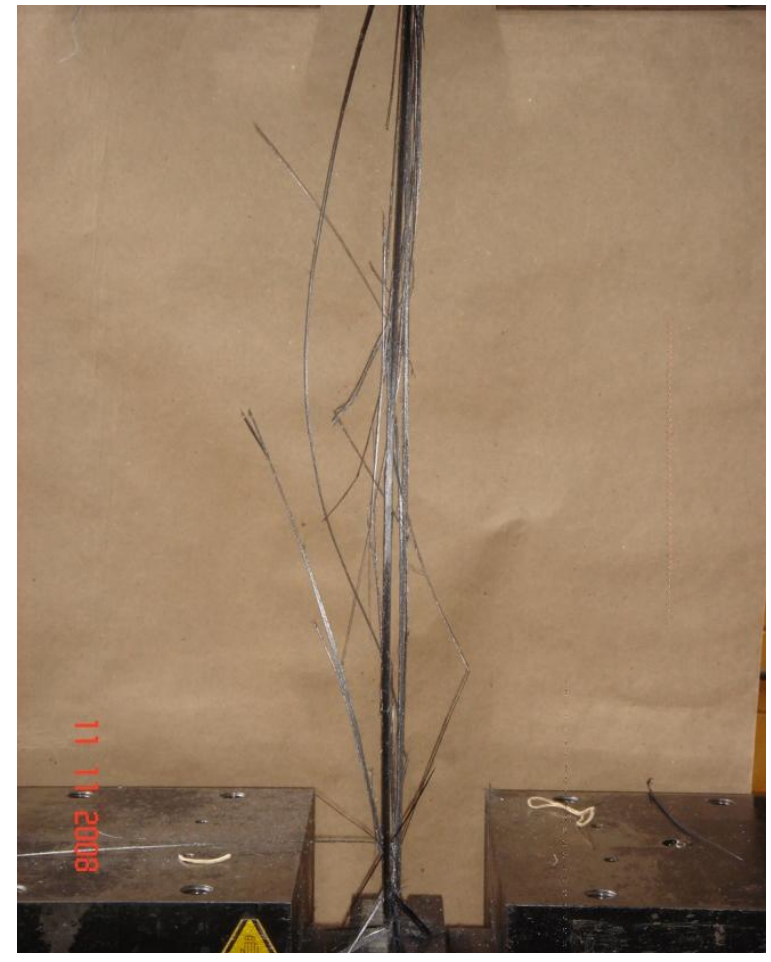

a) corpo de prova após ruptura

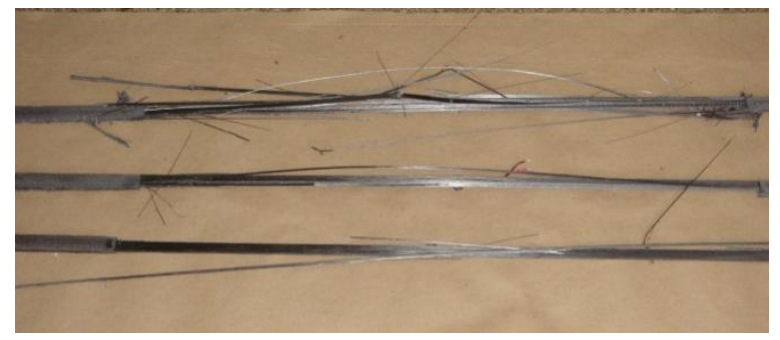

b) corpos de prova após ensaio de caracterização

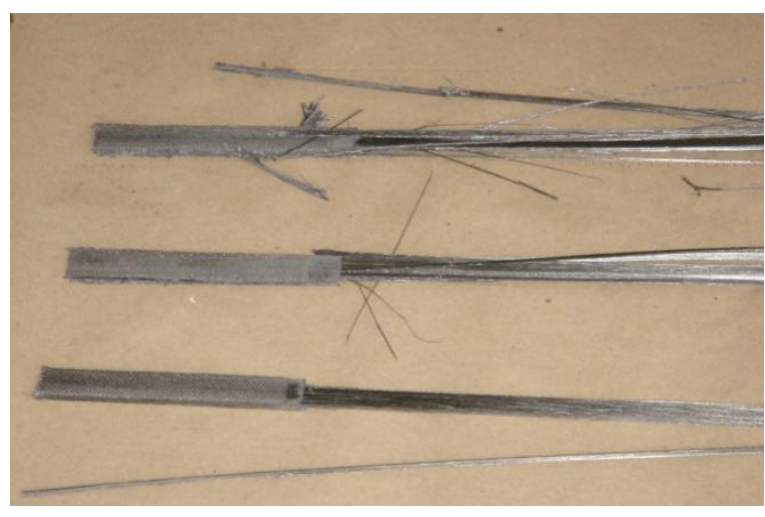

c) detalhe das abas íntegras após ensaios

Figura 4.4 - Aspecto dos laminados após ensaio de caracterização

A Figura 4.5 mostra o comportamento linear do laminado até a ruptura: 


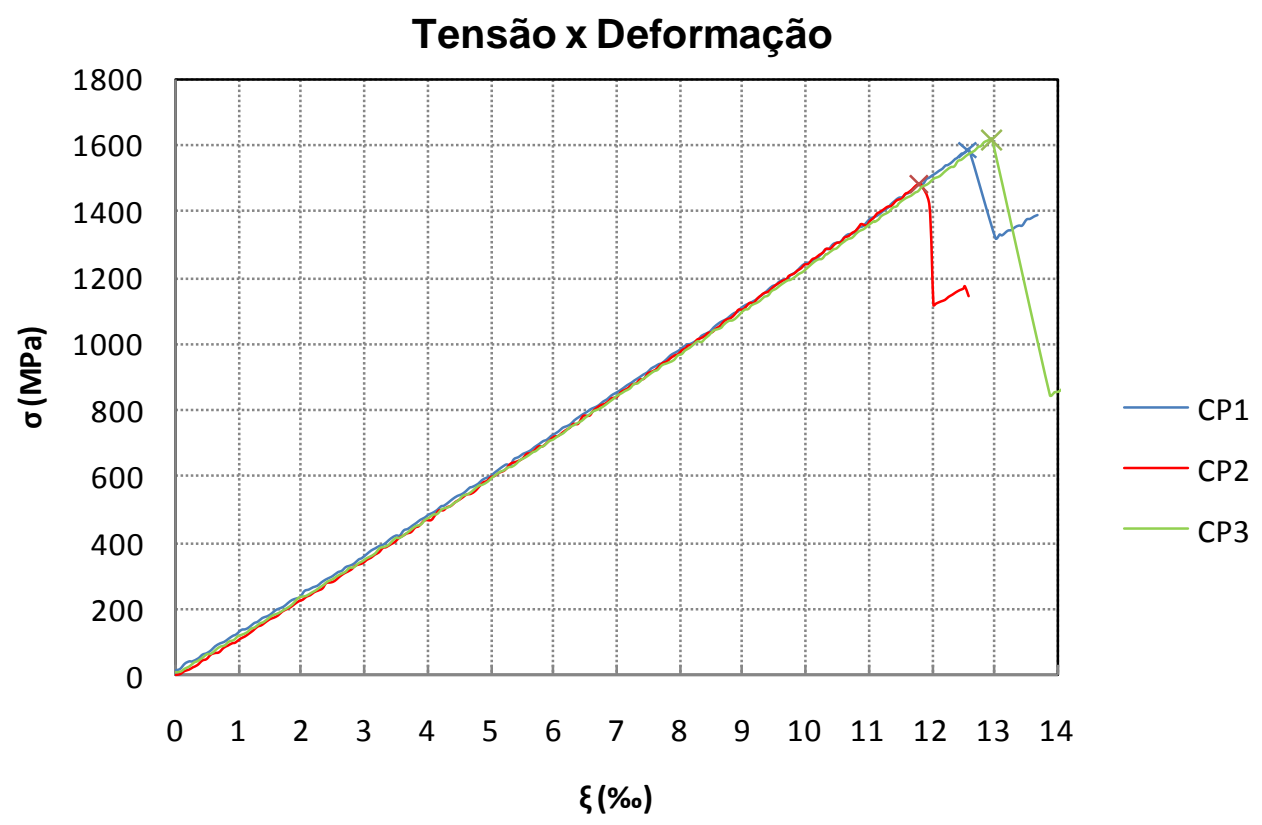

Figura 4.5 - Gráfico tensão x deformação dos três corpos de prova

De acordo com a norma, o módulo de elasticidade é calculado de maneira usual:

$$
E_{c}=\frac{\Delta \sigma}{\Delta \varepsilon}
$$

mas os limites são estabelecidos e têm como ponto inicial o valor de $1000 \mu \varepsilon$ e como ponto final o valor de $3000 \mu \varepsilon$ para materiais que suportam mais que $6000 \mu \varepsilon$ de deformação.

Diante do exposto, a Tabela 4.5 apresenta todos os valores encontrados nos ensaios de caracterização do laminado:

Tabela 4.5 - Propriedades físicas do laminado obtidas em ensaios de caracterização

\begin{tabular}{|c|c|c|c|c|}
\hline $\mathbf{C P}$ & $\begin{array}{c}\text { Força Máxima } \\
(\mathbf{k N})\end{array}$ & $\begin{array}{c}\text { Tensão Máxima } \\
\text { (MPa) }\end{array}$ & $\begin{array}{c}\text { Deformação } \\
\text { última }\left(\xi_{\mathrm{u}}\right) \\
(\%)\end{array}$ & $\begin{array}{c}\text { Módulo de } \\
\text { Elasticidade } \\
\text { (GPa) }\end{array}$ \\
\hline 1 & 53,56 & 1588 & 1,26 & 115 \\
\hline 2 & 49,90 & 1479 & 1,18 & 118 \\
\hline 3 & 54,56 & 1617 & 1,30 & 116 \\
\hline Média & 52,67 & 1562 & 1,25 & 116 \\
\hline
\end{tabular}


Comparando esses valores com àqueles fornecidos pelo fabricante, percebeu-se uma variação significativa e até mesmo preocupante quando se trata de dimensionamento para reforço de estruturas.

Tabela 4.6 - Comparação entre as propriedades físicas do laminado

\begin{tabular}{|c|c|c|c|c|c|c|}
\hline \multirow[t]{2}{*}{$\begin{array}{c}\text { Origem } \\
\text { dos dados }\end{array}$} & \multicolumn{2}{|c|}{$\begin{array}{c}\text { Dimensão } \\
\text { mm }\end{array}$} & \multirow{2}{*}{$\begin{array}{l}\text { Área } \\
\text { mm }^{2}\end{array}$} & \multirow{2}{*}{$\begin{array}{c}\text { Resistência } \\
\text { à tração } \\
\text { MPa }\end{array}$} & \multirow{2}{*}{$\begin{array}{c}\text { Módulo de } \\
\text { elasticidade } \\
\text { GPa }\end{array}$} & \multirow[t]{2}{*}{$\begin{array}{c}\text { Deformação } \\
\text { última }\end{array}$} \\
\hline & Larg. & Esp. & & & & \\
\hline Ensaio & 15,91 & 2,12 & 33,73 & 1562 & 116 & 0,0125 \\
\hline Fabricante & 16,00 & 2,00 & 32,00 & 2068 & 131 & 0,0170 \\
\hline Desvio & $-0,56 \%$ & $6,00 \%$ & $5,41 \%$ & $-24,47 \%$ & $-11,45 \%$ & $-26,47 \%$ \\
\hline
\end{tabular}

\subsubsection{Resina}

Para fixação dos laminados nos entalhes, foi utilizada a resina bi-componente de base epóxi conhecida pelo nome comercial de Sikadur ${ }^{\circledR}$ 330. Por questões de cronograma, nenhum ensaio pode ser realizado para confirmação dos dados fornecidos pelo fabricante. Em contato com um consultor técnico da Sika, para possível acompanhamento de ensaios realizados por eles, veio a informação de que o material é importado e seus dados não são confirmados no Brasil.

Além disso, confirmou-se a utilização inadequada desse tipo de resina para uso em conjunto com o laminado, sendo a resina indicada, a Sikadur ${ }^{\circledR}$ 30. Segundo o consultor, a principal diferença entre elas é a viscosidade, tendo a Sikadur ${ }^{\circledR} 30$ um aspecto menos fluido.

Uma explicação para ocorrência desse fato é que no trabalho de Fonseca (2007), foi utilizada a resina fornecida em conjunto com o laminado (adquiridos junto à empresa Rogermat) e os resultados foram ruins, com pouco aproveitamento do laminado e com problemas de trabalhabilidade, já que sua consistência era bastante fluida. Em paralelo, estavam acontecendo no laboratório, ensaios com tecido de fibra de carbono, onde utilizavam a resina Sikadur ${ }^{\circledR} 330$ e os resultados eram satisfatórios. Então, os ensaios de Fonseca (2007) foram repetidos com essa resina e os resultados e a trabalhabilidade foram de qualidade superior. Decidiu-se na época continuar utilizando o Sikadur ${ }^{\circledR} 330$ e a decisão perdurou para esse trabalho também. 
Capítulo 4 - Ensaio de Aderência

Os dados fornecidos pelo fabricante para o Sikadur ${ }^{\circledR} 330$ podem ser vistos na Tabela 4.7:

Tabela 4.7 - Propriedades da resina fornecidas pelo fabricante

\begin{tabular}{c|c|c|c|c}
\hline \multirow{2}{*}{$\begin{array}{c}\text { Resistência à } \\
\text { Tração }\end{array}$} & $\begin{array}{c}\text { Resistência à } \\
\text { Aderência }\end{array}$ & \multicolumn{2}{|c|}{ Módulo de Elasticidade } & $\begin{array}{c}\text { Alongamento } \\
\text { na Ruptura }\end{array}$ \\
\cline { 3 - 4 } & nPa Flexão & $\begin{array}{c}\text { na Tração } \\
\text { (MPa) }\end{array}$ & $(\%)$ \\
\hline 30 & $(\mathbf{M P a})$ & 3800 & 4500 & 0,9 \\
\hline
\end{tabular}

\subsection{Realização do ensaio}

Passados doze dias da concretagem, os blocos de concreto foram retirados da câmara úmida e procedeu-se a execução dos entalhes. Utilizando dois discos de corte por meio de via úmida, as aberturas ficaram com aproximadamente $5 \mathrm{~mm}$ de espessura e $18 \mathrm{~mm}$ de profundidade. Ao término, os modelos foram lavados e mantidos na parte externa do laboratório para secagem. No outro dia, o pó remanescente foi retirado com jato de ar comprimido e com estopa embebida em álcool.

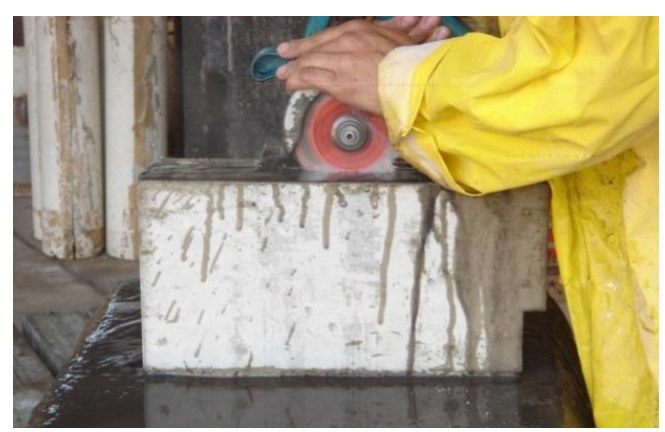

a) execução dos entalhes com discos de corte e via úmida

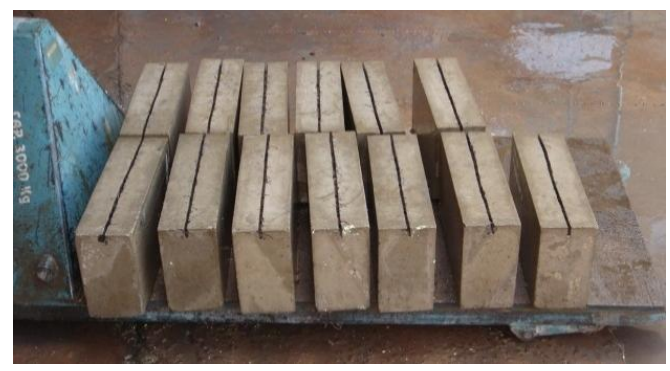

b) blocos entalhados e lavados

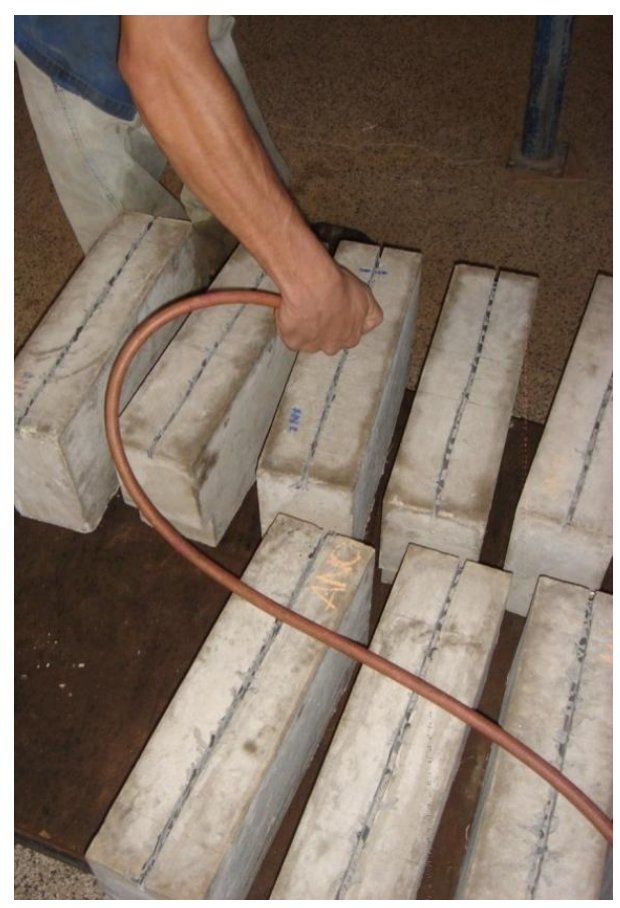

c) limpeza dos blocos com jato de ar comprimido

Figura 4.6 - Procedimentos para execução e limpeza dos entalhes 
Os laminados foram cortados com $82 \mathrm{~cm}$ de comprimento e limpos com álcool isopropílico antes de receberem a marcação da região de ancoragem. Extensômetros semelhantes aos utilizados no ensaio de caracterização foram fixados a $40 \mathrm{~cm}$ de uma das extremidades do laminado, ficando os restantes $42 \mathrm{~cm}$ livres para a região de ensaio (Bloco A). Esses $2 \mathrm{~cm}$ de folga são importantes para a fixação de pequenas chapas no final da zona de ancoragem que servem de base para a medição de deslocamento. Nelas, são acopladas cantoneiras metálicas onde se apoia o cursor do transdutor de deslocamento. É interessante que esse conjunto não fique muito próximo ao apoio para evitar o destacamento durante o desenvolvimento do ensaio. Composição semelhante é utilizada no início da zona de ancoragem.

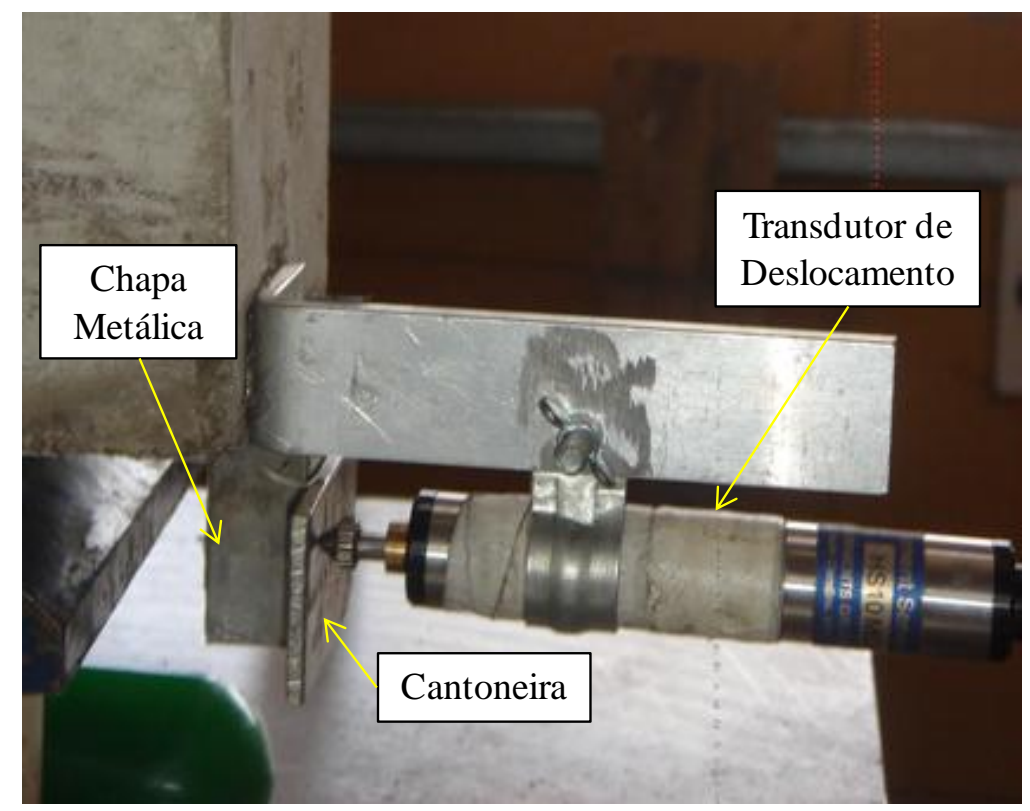

Figura 4.7 - Detalhe do conjunto para medição do deslocamento no final da zona de ancoragem

A região de ancoragem no laminado foi delimitada com fixação de fita adesiva para que a resina não espalhasse mais que o comprimento desejado. Os blocos de concreto (Blocos A) também tiveram os comprimentos de ancoragem marcados, formando um gabarito para facilitar a colocação do laminado e a visualização ao aplicar a resina. Esta, por sua vez, foi misturada nas condições e proporções indicadas pelo fabricante e aplicadas com auxílio de espátula tanto no laminado quanto no entalhe. Após a colocação do laminado no entalhe, o excesso de resina foi retirado e os modelos permaneceram intactos até a realização dos ensaios, que ocorreram vinte dias depois. 
Toda movimentação realizada com os modelos foi precedida da colocação da mesma rótula utilizada no ensaio de modo a não produzir uma flexão no conjunto e com isso tensionar o laminado antes da hora, prejudicando os resultados.

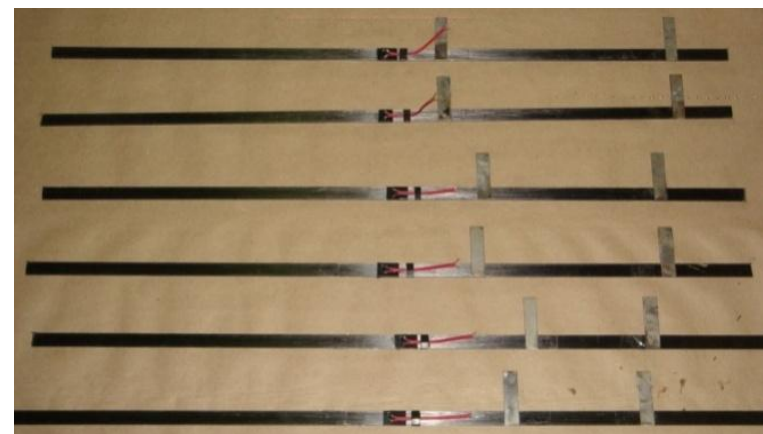

a) laminados com extensômetro e demarcados

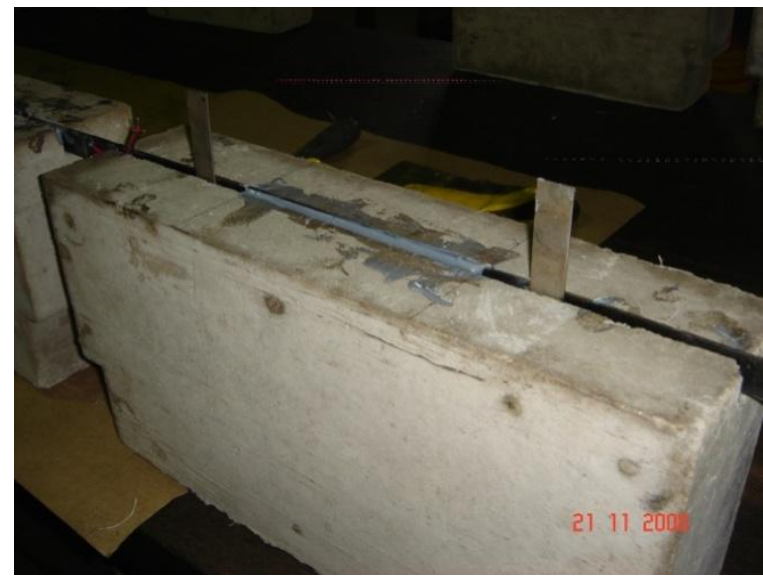

c) aspecto final do reforço

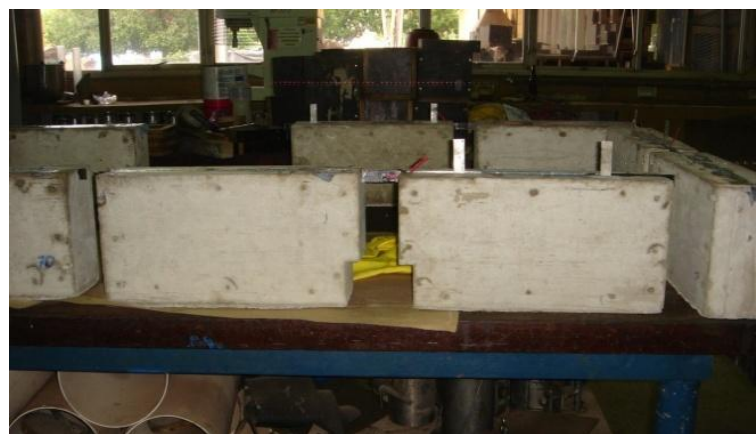

b) processo de inserção do laminado no entalhe

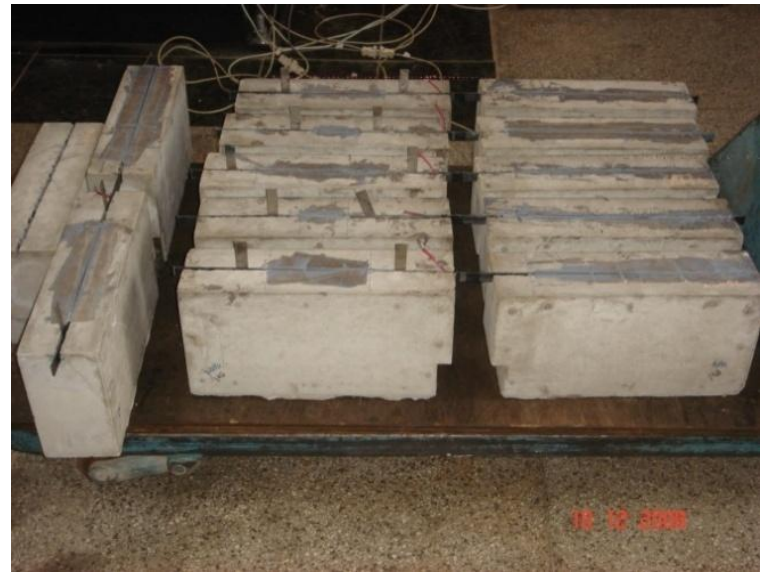

d) corpos de prova prontos para ensaio

Figura 4.8 - Preparação do reforço com seus respectivos comprimentos de ancoragem

O ensaio como já comentado, é simples de ser executado e não requer uma complexa instrumentação. Foi utilizada a máquina servo-hidráulica da marca Instron, sob controle de deslocamento do pistão a uma taxa de $0,005 \mathrm{~mm} / \mathrm{s}$. O sistema de aquisição de dados foi o System 5000 da marca Vishay. Os demais itens podem ser observados na Figura 4.9: 


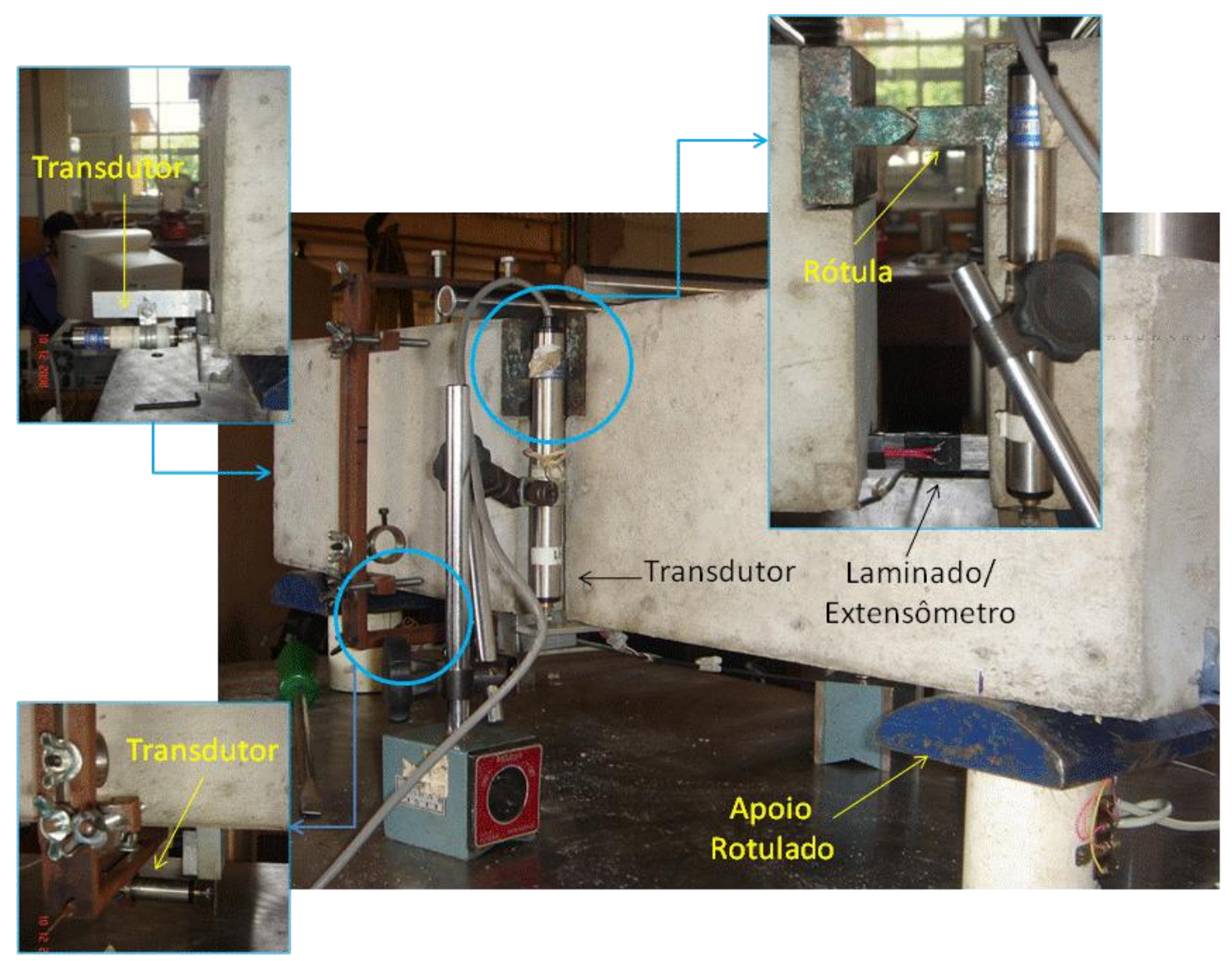

Figura 4.9 - Esquema de montagem do ensaio

\subsection{Resultados e análises}

Após concluir os ensaios, a primeira análise realizada foi em relação à forma de ruptura da ligação. Para isso, uma cuidadosa inspeção visual nos modelos foi necessária e verificou-se que, com exceção de um deles, todas as falhas ocorreram entre o laminado e a resina, sem qualquer sinal de fissuração no concreto. $\mathrm{O}$ modelo acima citado apresentou profundidade do entalhe inferior à largura do laminado, permitindo que parte desse ficasse exposto. A redução da área de aderência possibilitou o deslizamento do laminado.

Esse fato pode ser explicado através da Figura 4.10: 


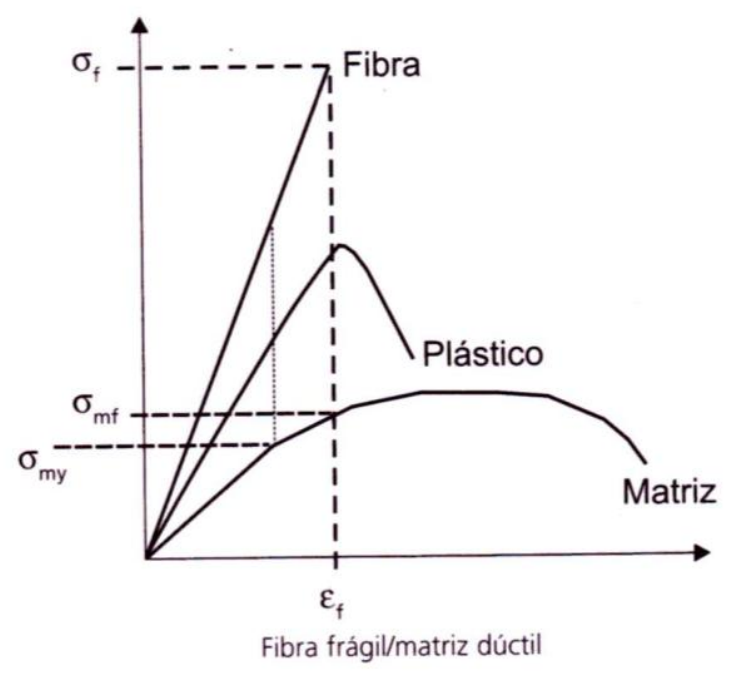

Figura 4.10 - Diagrama tensão $x$ deformação dos sistemas de compósitos de fibras de carbono (CFC) (Adaptado de MACHADO,2002, p.36)

Como a resistência da resina é muito inferior à resistência do laminado, $30 \mathrm{MPa} \mathrm{e}$ $2068 \mathrm{MPa}$, respectivamente (dados fornecidos pelos fabricantes), toda a responsabilidade estrutural fica por conta do polímero. A resina precisa efetivamente responder aos efeitos de deformação do sistema e garantir a aderência entre o conjunto laminado-resina-concreto. Por isso, deve apresentar resistência suficiente até o ponto de deformação máxima do laminado. Ou seja, se o comprimento de ancoragem for inferior ao necessário, a força de aderência será insuficiente para proporcionar a deformação necessária do sistema, provocando o deslizamento do laminado e a falha do reforço.

Em relação ao concreto, como ele tem o segundo menor módulo de elasticidade do conjunto, a chance de ocorrer falha em sua aderência com a resina também é menor. Caso isso ocorresse, o laminado mal seria solicitado. Mas falhas na aplicação da resina e formação de bolhas podem favorecer esse colapso.

\subsubsection{Força no laminado}

Adotando-se o mesmo procedimento das pesquisas de Fonseca (2007) e Cruz e Barros (2002), a força no laminado foi obtida por duas maneiras:

a) Equação de Equilíbrio: assim como descreve Giongo (2008) "momentos fletores solicitantes são equilibrados por momentos resistentes gerados por binários cujas 
forças, uma de tração e outra de compressão são as resultantes de tensões normais".

$$
\begin{gathered}
\frac{V_{A}+V_{B}}{2} . L=F_{l} . d \\
F_{l}=\frac{V_{A}+V_{B}}{2 . d} . L
\end{gathered}
$$

onde:

$F_{l}=$ força no laminado;

$V_{A} \mathrm{e} V_{B}=$ reações de apoio obtidas através das células de carga;

$L=$ distância entre apoio e o ponto de aplicação da carga;

$d=$ altura útil ou braço de alavanca.

b) Deformação do laminado obtida através do extensômetro:

$$
\begin{gathered}
E=\frac{\sigma}{\varepsilon} \\
\frac{F_{l}}{A}=E . \varepsilon \\
F_{l}=\text { E.c.l.e }
\end{gathered}
$$

onde:

$F_{l}=$ força no laminado;

$E=$ módulo de elasticidade do laminado;

$\xi=$ deformação obtida no extensômetro;

$l=$ largura do laminado;

$e=$ espessura do laminado.

Recordando da seção 4.1 a nomenclatura M $\underline{x L A y ~ r e l a c i o n a ~ o ~} \underline{x}$ com o número do modelo (1 ou 2) e o $y$ com o comprimento de ancoragem. 
Como mostra a Figura 4.11, os dois métodos apresentam resultados próximos no início do ensaio, quando os materiais ainda se comportam linearmente. Em seguida os valores se distanciam, sendo os obtidos pelo extensômetro, sempre os mais conservadores. No M2LA140 houve falha no funcionamento do extensômetro e para que as comparações fossem equivalentes, os resultados foram obtidos através das equações de equilíbrio.

Mais crítico foi o problema de confecção ocorrido no M1LA210, como comentado anteriormente, onde o descarte de seus resultados é a atitude mais coerente.

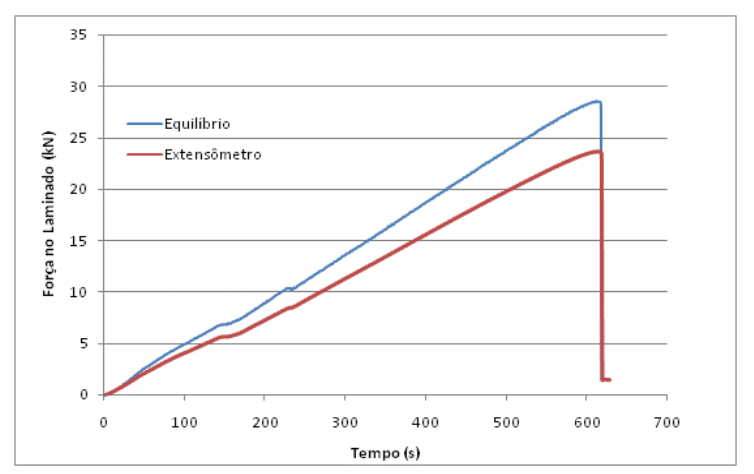

a) M1LA70

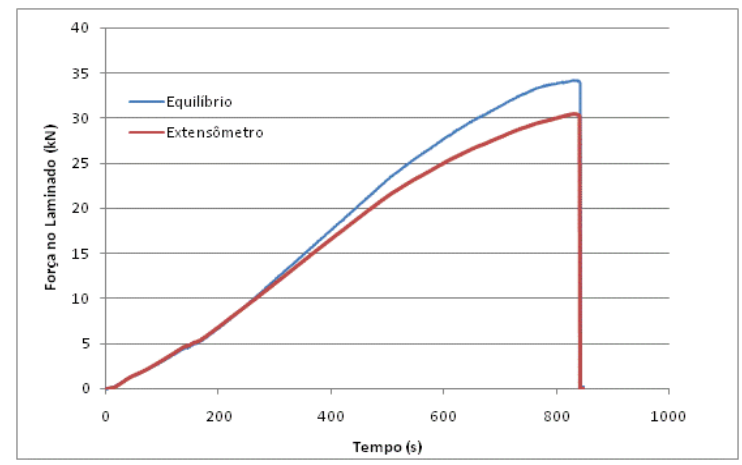

c) M1LA140

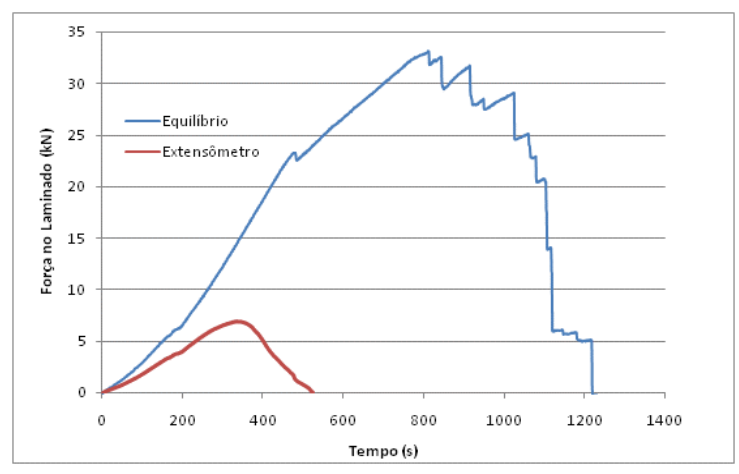

e) M1LA210**

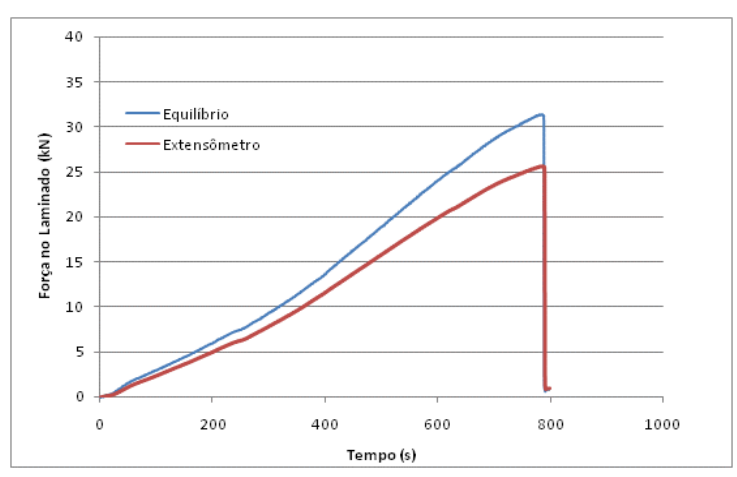

b) M2LA70

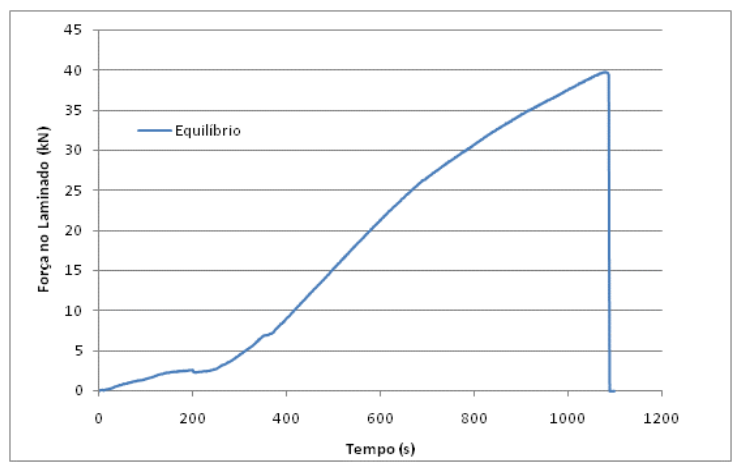

d) M2LA140*

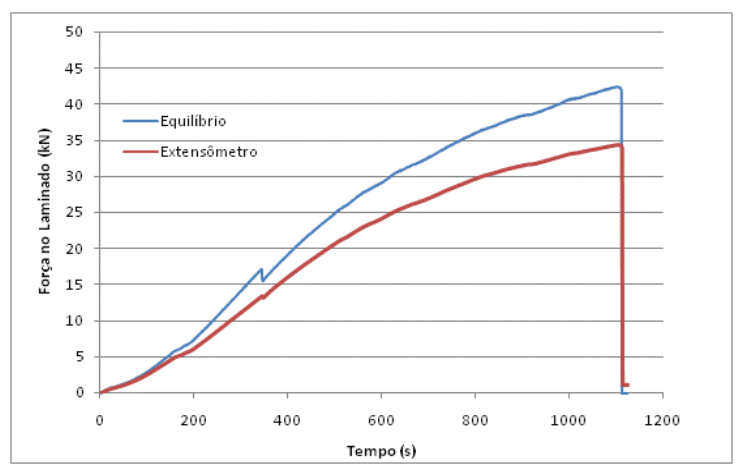

f) M2LA210 
* Problemas com funcionamento do extensômetro

*** Problemas na confecção do modelo e por isso, resultados que serão desconsiderados

Figura 4.11 - Gráficos força no laminado x tempo de todos os modelos obtidos pela equação de equilíbrio e pelo extensômetro

Observa-se na Figura 4.12 que a força imposta ao laminado mostrou-se diretamente proporcional ao comprimento de ancoragem:

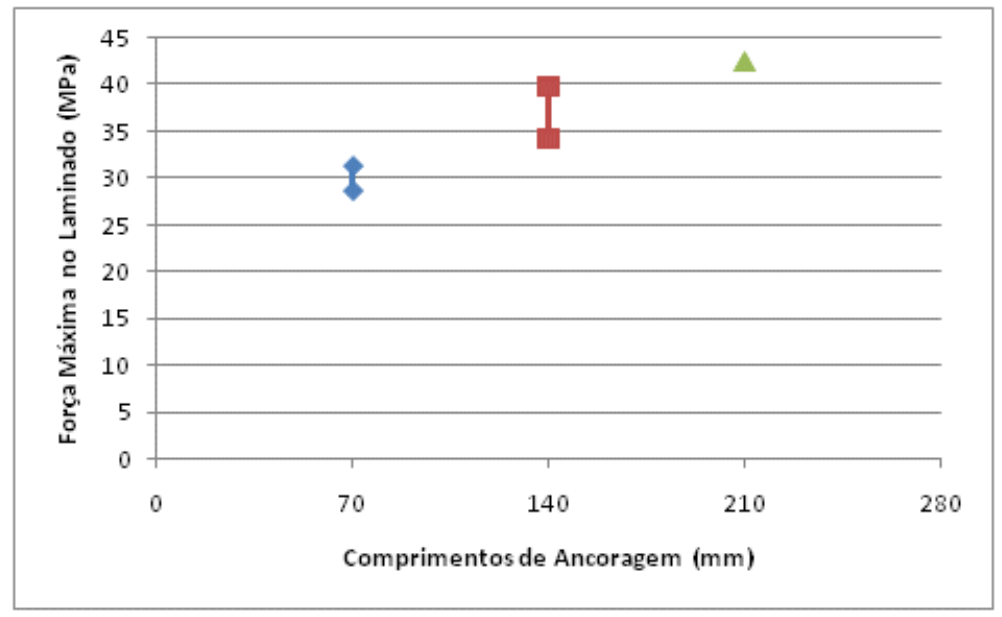

Figura 4.12 - Gráfico força máxima no laminado x comprimento de ancoragem dos modelos com valores obtidos pela equação de equilíbrio

Na Figura 4.13 os gráficos apontam para o deslocamento vertical dos modelos:

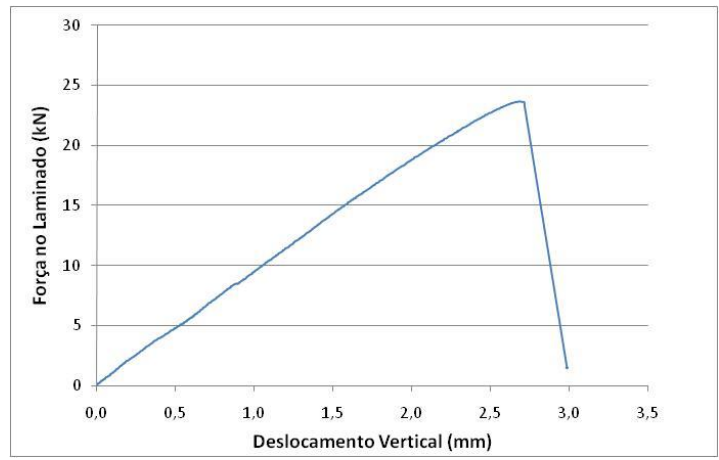

a) M1LA70

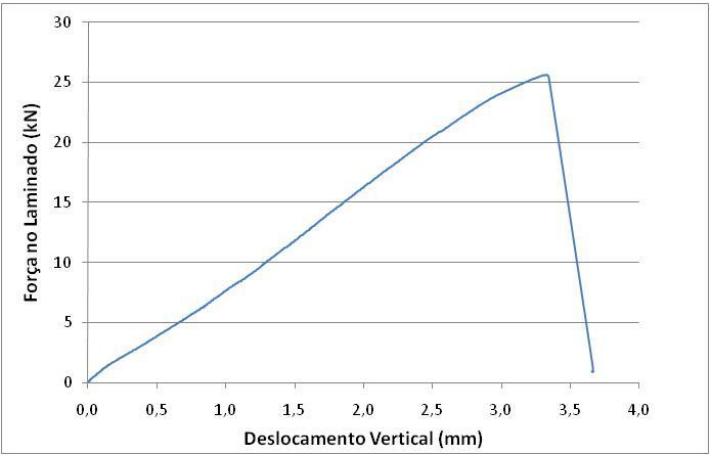

b) M2LA70 


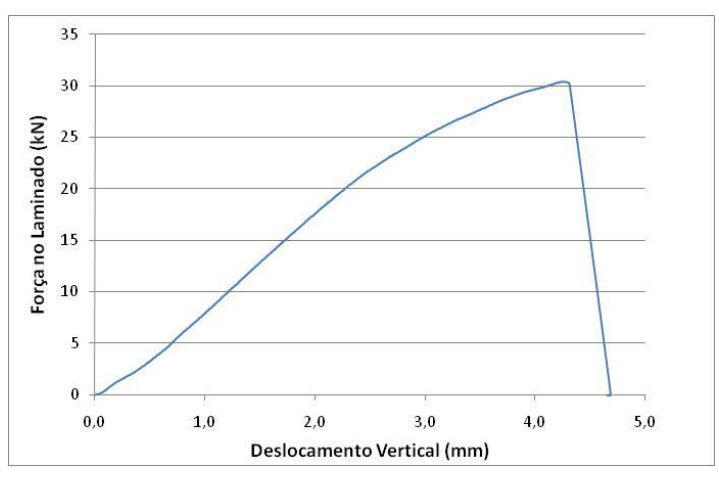

c) M1LA140

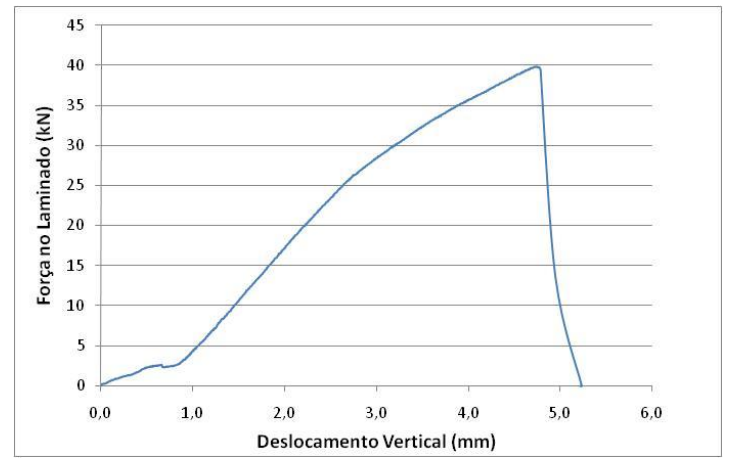

d) M2LA140

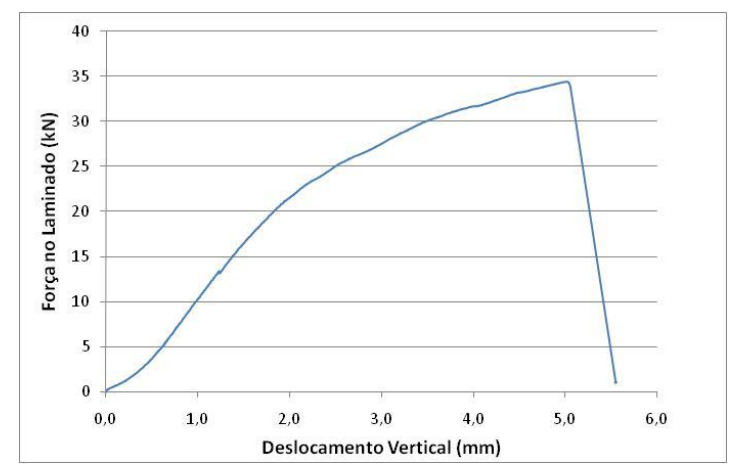

e) M2LA210

Figura 4.13 - Gráfico força no laminado x deslocamento vertical dos modelos com valores obtidos pela equação de equilíbrio

Observa-se um comportamento linear do laminado até atingir o pico de carga, sobretudo para o comprimento de $70 \mathrm{~mm}$ de ancoragem. Essa característica não ocorre para o comprimento de $210 \mathrm{~mm}$. Isso se deve, possivelmente, à maior mobilização e deslizamento do adesivo, permitindo que o laminado atinja cargas maiores, com menores deslocamentos verticais. Por exemplo, se tomar como referência a força no laminado igual a $20 \mathrm{kN}$, percebese que quanto maior o comprimento de ancoragem, menor o deslocamento vertical.

\subsubsection{Tensão de aderência}

Talvez essa seja a característica mais importante do estudo em questão já que a aderência é que torna possível a ação conjunta dos materiais.

Do estudo de ancoragem com barras de aço tem-se:

$$
\tau_{b}=\frac{A_{s}}{\pi \cdot \varphi} \cdot \frac{d \sigma_{s}}{d_{x}}
$$


Capítulo 4 - Ensaio de Aderência

Analogamente para o laminado:

$$
\tau_{l}=\frac{F_{l}}{2 \cdot(e+l) \cdot L A}
$$

onde:

$F_{l}=$ tração no laminado;

$l=$ largura do laminado;

$e=$ espessura do laminado;

$L A=$ comprimento de ancoragem

A Figura 4.14 mostra os gráficos com os valores da tensão de cisalhamento no início e no final da zona de ancoragem obtidos através da Equação 4.9:

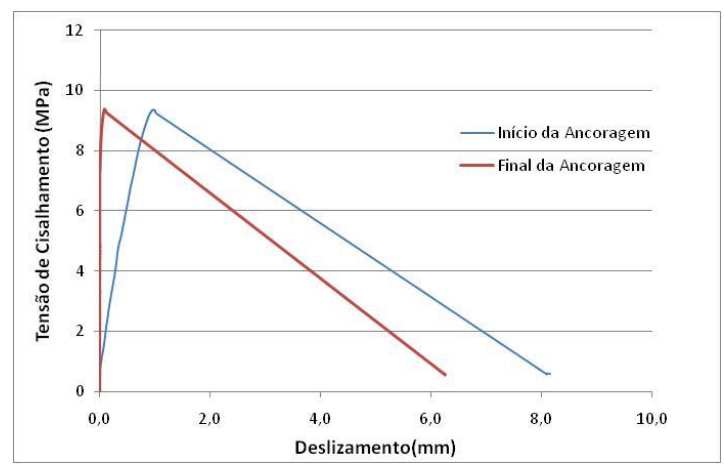

a) M1LA70

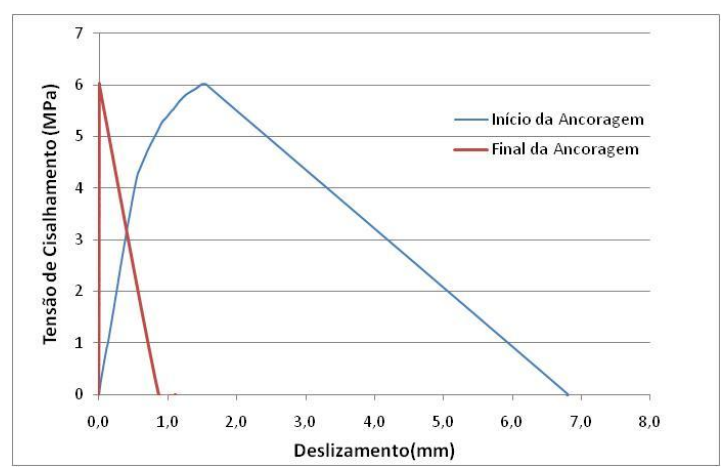

c) M1LA140

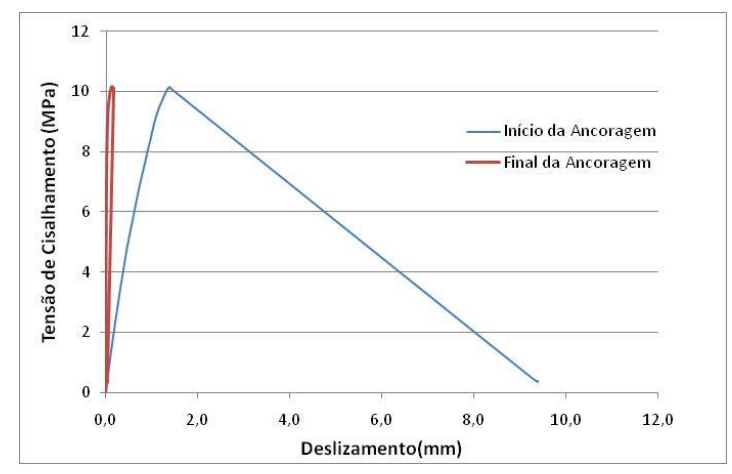

b) M2LA70

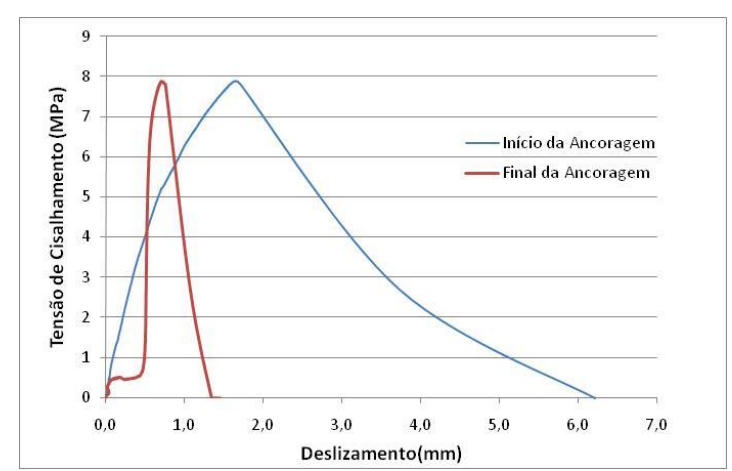

d) M2LA140 


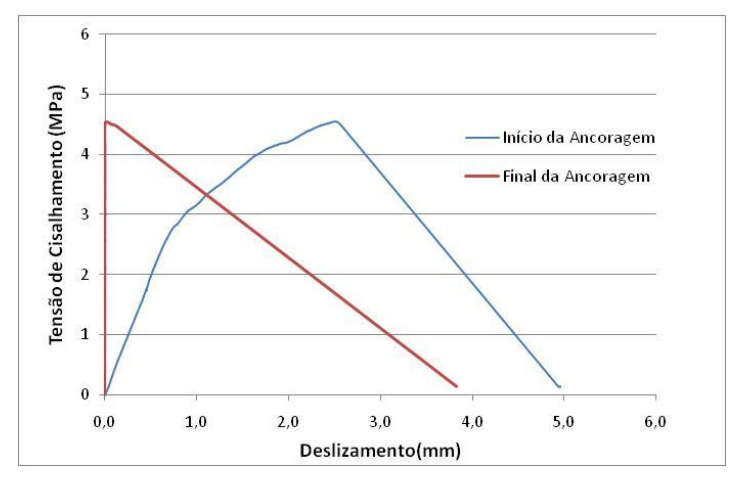

e) M2LA210

Figura 4.14 - Gráficos tensão de cisalhamento x deslizamento

De forma geral, o início da zona de ancoragem tem seu início linear e em seguida passa para um regime não-linear, ditado pelo comportamento do adesivo até a força máxima. Por fim, com a deformação do adesivo e o possível rompimento de aderência entre laminado e resina, há a perda de carga e o deslizamento torna-se mais intenso. Já no final da zona de ancoragem, corresponde àquele esperado para um ensaio de arrancamento clássico: no início o deslizamento é nulo e em seguida aparece uma zona quase linear até atingir a força máxima. Após o pico de força, as variações do deslizamento apresentam um ramo descendente cuja inclinação exprime a fragilidade do comportamento da ruptura da ligação de aderência.

Apenas no M2LA70 houve desprendimento do dispositivo de referência colado ao laminado no final da zona de ancoragem. Todavia, pelo M1LA70, pode-se concluir que a ruptura se deu de maneira mais dúctil, se comparada a dos demais modelos. Surpreendentemente, o comprimento de $140 \mathrm{~cm}$ de ancoragem foi o que apresentou o comportamento mais frágil dos três comprimentos estudados, se se analisar o final do comprimento de ancoragem. Mas ao analisar o início, nota-se que quanto maior o comprimento de ancoragem, maior o deslizamento do conjunto resina-laminado para uma mesma tensão de cisalhamento. Isto remete à conclusão de que quanto maior esse deslizamento, maior o aproveitamento do laminado.

Fazendo um paralelo entre comprimentos de ancoragem, cisalhamento máximo e tensão máxima no laminado, obtém-se o seguinte panorama (Tabela 4.8): 
Capítulo 4 - Ensaio de Aderência

Tabela 4.8 - Tensão no laminado e cisalhamento máximos para cada comprimento de ancoragem

\begin{tabular}{c|c|c}
\hline Modelos & $\begin{array}{c}\text { Cisalhamento máximo } \\
\text { no concreto (MPa) }\end{array}$ & $\begin{array}{c}\text { Tensão máxima no } \\
\text { laminado (MPa) }\end{array}$ \\
\hline M1LA70 & 9,38 & 702 \\
\hline M2LA70 & 10,16 & 760 \\
\hline M1LA140 & 6,03 & 1179 \\
\hline M2LA140 & 7,88 & 1022 \\
\hline M2LA210 & 4,55 & 903 \\
\hline
\end{tabular}

Graficamente a situação é a seguinte (Figura 4.15):

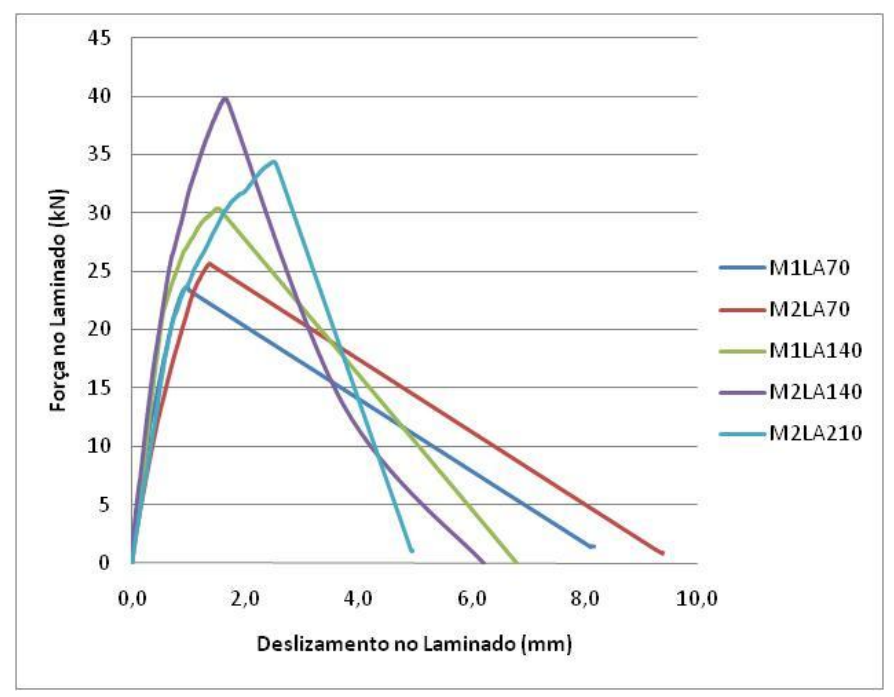

Figura 4.15 - Gráfico força no laminado x deslizamento

Observa-se que quanto maior o comprimento de ancoragem, maior o aproveitamento do laminado. Porém, existe um valor máximo a partir do qual o aumento desse comprimento não incrementa mais eficiência ao reforço.

A Figura 4.16 apresenta esse patamar: 


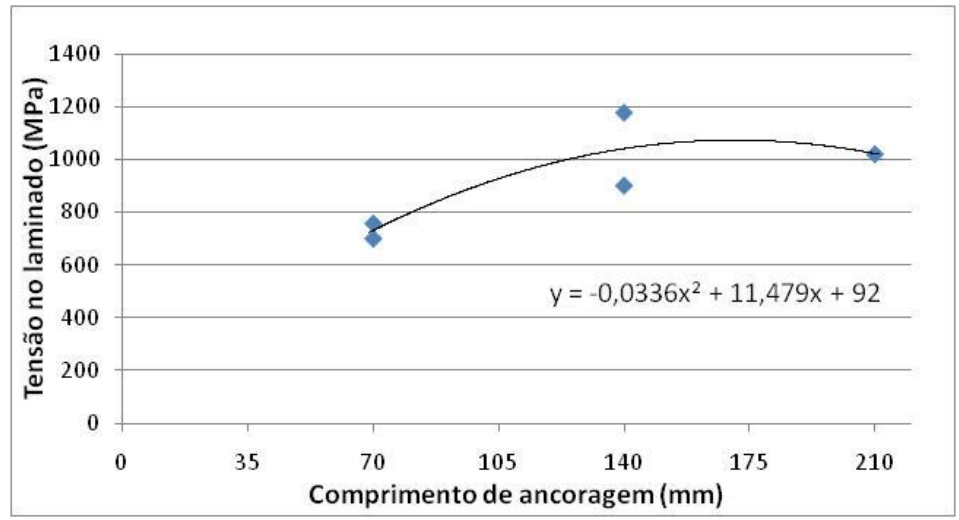

Figura 4.16 - Gráfico tensão no laminado x comprimento de ancoragem

\subsection{Conclusão}

Realizadas as devidas análises, pode-se concluir que:

- com o uso do compósito cimentício não houve fissuração do concreto adjacente à região de ancoragem do laminado, sendo que todas as rupturas ocorreram entre o laminado e a resina;

- a força imposta ao laminado é diretamente proporcional ao comprimento de ancoragem, até que se atinja um patamar de aproveitamento. Existe um comprimento ideal, a partir do qual, o aumento do comprimento não incrementa eficiência ao reforço;

- quanto maior o comprimento de ancoragem, menor a tensão de cisalhamento e menor o deslocamento vertical para uma mesma tensão instalada no laminado. 
Neste capítulo descrevem-se todos os cálculos, procedimentos e equipamentos utilizados para a realização do ensaio à flexão das vigas denominadas como principais. Fazem parte desse grupo, vigas reforçadas com laminado de polímero reforçado com fibra de carbono (PRFC) inserido no cobrimento de concreto, sob três maneiras distintas de ancoragem. Pretende-se incorporar nelas todo o aprendizado adquirido pelos ensaios precedentes, assim como associar resultados e experiências transmitidas por outros pesquisadores.

O concreto para reconstituir a face tracionada da viga foi estudado no Capítulo 3 e recebeu o nome de compósito CPM1,5A1C (1,5\% de fibra e 1\% de microfibra). Dentre as opções apresentadas, foi o que obteve as melhores resistências à tração, com satisfatória trabalhabilidade, dentro da limitação da taxa de microfibra. Utilizando este mesmo compósito para confeccionar blocos não armados, estudou-se a aderência entre ele, a resina e o laminado de PRFC (Capítulo 4). Observou-se que ele resistiu bem às solicitações do laminado, sem qualquer sinal de fissuração. O final do ensaio deu-se sempre por rompimento da aderência entre resina e laminado e pode-se concluir que quanto maior o comprimento de ancoragem, menor a tensão de cisalhamento instalada e maior a força imposta ao laminado.

Com esses subsídios, foi possível idealizar o ensaio final, que passa a ser descrito nas próximas seções.

\subsection{Propriedades das vigas}

No total, foram moldadas oito vigas idênticas com seção transversal 17 x $35 \mathrm{~cm} \mathrm{e}$ comprimento de $360 \mathrm{~cm}$. Em razão do volume, o concreto foi adquirido junto a uma usina da região, sob especificação de resistência à compressão de $30 \mathrm{MPa}$. As fôrmas de madeira receberam desmoldante e as armaduras, espaçadores. A Figura 5.1 apresenta as dimensões das vigas e o detalhamento das armaduras: 
VIGA PRINCIPAL (8X)

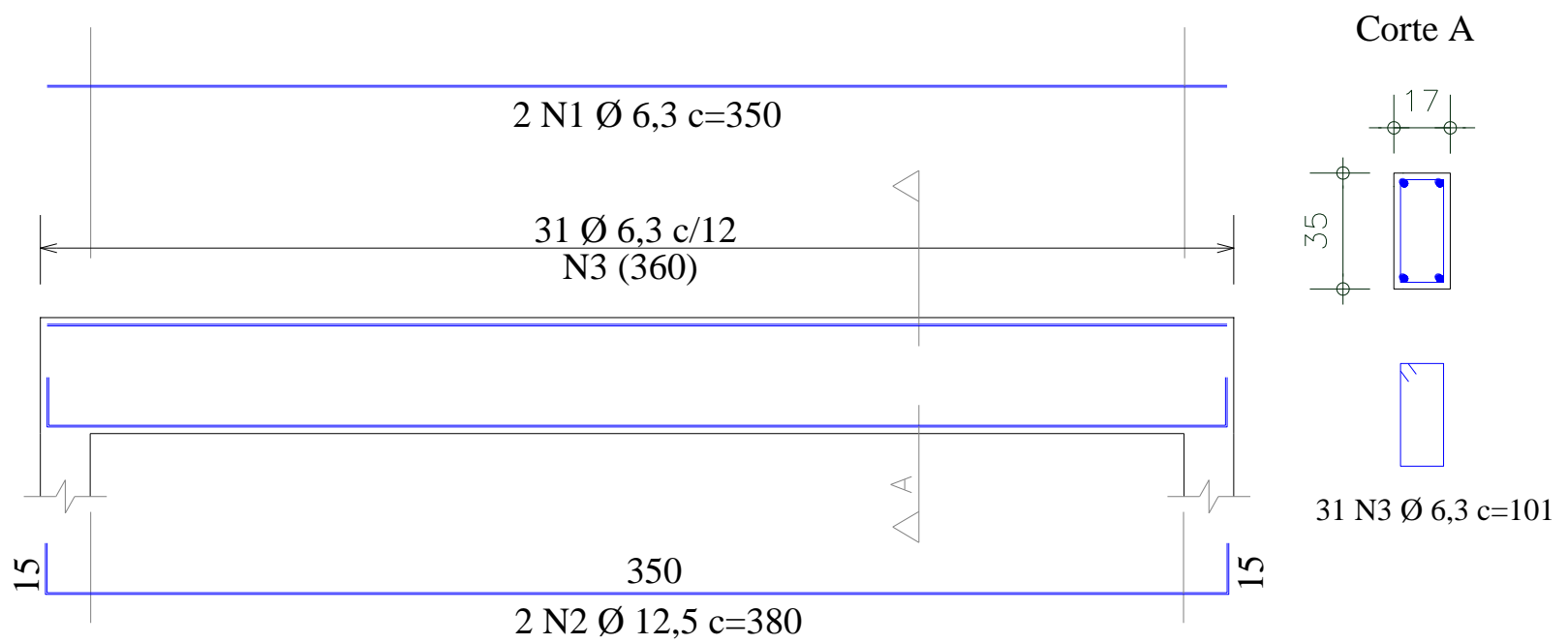

Figura 5.1 - Detalhamento das armaduras das vigas

As vigas aqui apresentadas são idênticas às utilizadas no trabalho de Ferrari (2007), o que possibilita a comparação entre as técnicas e demais análises.

A intenção do autor do trabalho anterior, com relação ao detalhamento das armaduras foi a seguinte:

Essa viga foi dimensionada com reduzida taxa de armadura longitudinal de modo que o seu estado limite último fosse caracterizado pela deformação excessiva da armadura sem ruptura no concreto comprimido. A sua armadura transversal foi superdimensionada para que não ocorresse escoamento das barras de aço dos estribos.

Abaixo, a Figura 5.2 apresenta o processo de concretagem das oito vigas:
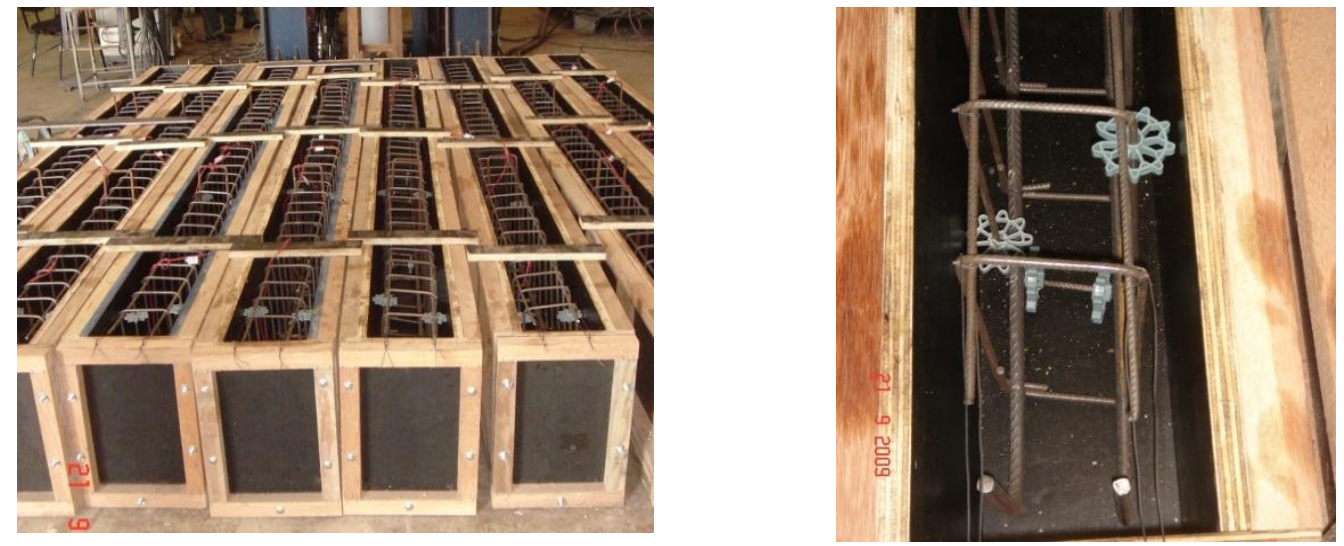
a) fôrmas de madeira

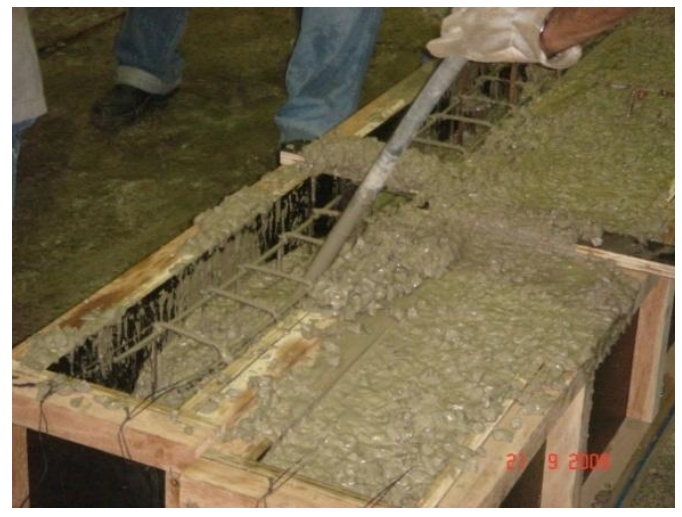

c) concretagem seguida de vibração b) detalhe dos espaçadores

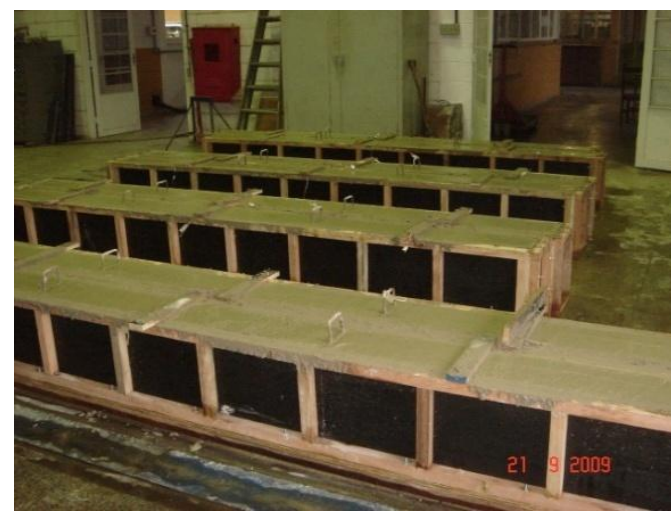

d) vigas concretadas

Figura 5.2 - Concretagem das vigas

Durante a concretagem das vigas, foram moldados seis corpos de prova cilíndricos 10 x $20 \mathrm{~cm}$ para realização dos ensaios de caracterização. Eles aconteceram na mesma data do ensaio principal e estão apresentados na seção 5.2.1.

A cura dos corpos de prova deu-se em câmara úmida, enquanto as vigas ficaram no interior do laboratório, cobertas por lonas plásticas durante três dias.

\subsection{Sistema de reforço}

As oito vigas foram separadas em quatro grupos descritos a seguir (Tabela 5.1), com o objetivo de buscar o melhor aproveitamento do reforço:

Tabela 5.1 - Características das vigas principais

\begin{tabular}{|c|c|c|}
\hline Grupo & Viga & Características \\
\hline \multirow{2}{*}{ A } & VA1 & \multirow{2}{*}{ Vigas de referência (sem reforço) } \\
\hline & VA2 & \\
\hline \multirow{2}{*}{$\mathrm{B}$} & VB1 & \multirow{2}{*}{ Vigas reforçadas com dois laminados de PRFC } \\
\hline & VB2 & \\
\hline $\mathrm{C}$ & VC1 & $\begin{array}{l}\text { Vigas cuja parte da região tracionada do concreto foi } \\
\text { removida de apoio a apoio, reconstituídas com o }\end{array}$ \\
\hline
\end{tabular}




\begin{tabular}{c|c|c}
\cline { 2 - 3 } & VC2 & $\begin{array}{r}\text { concreto CPM1,5A1C e reforçadas com dois laminados } \\
\text { de PRFC }\end{array}$ \\
\hline \multirow{2}{*}{ D } & VD1 & $\begin{array}{r}\text { Vigas cuja parte da região tracionada do concreto foi } \\
\text { removida apenas nos vão de cisalhamento, } \\
\text { reconstituídas com o concreto CPM1,5A1C e } \\
\text { reforçadas com dois laminados de PRFC }\end{array}$ \\
\cline { 2 - 3 } & VD2 & \\
\hline
\end{tabular}

Os detalhes desses grupos podem ser vistos na Figura 5.3:

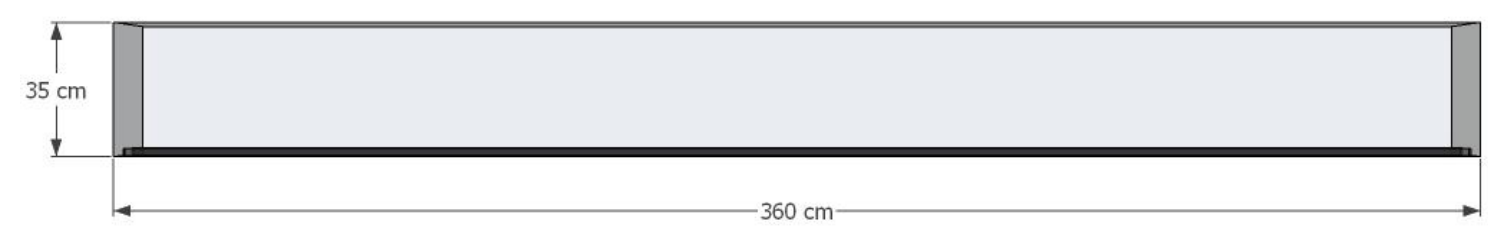

a) Viga do Grupo B

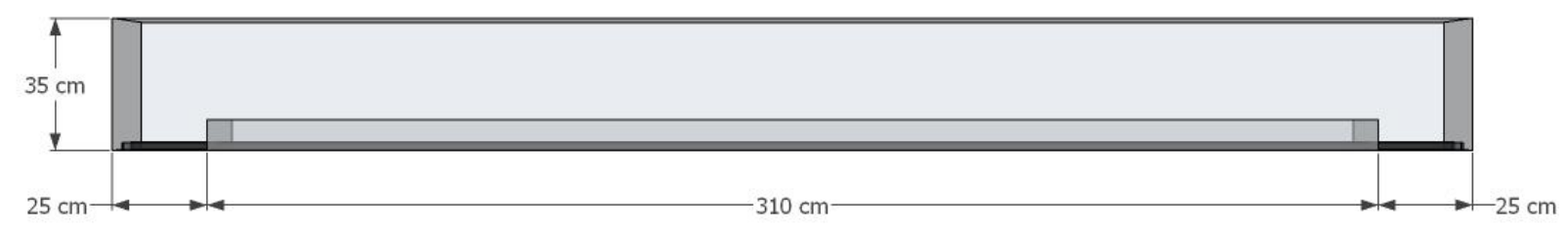

b) Viga do Grupo C

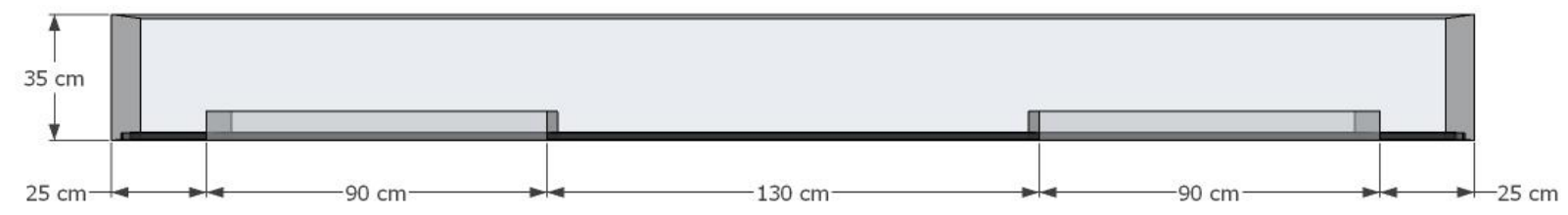

c) Viga do Grupo D

Figura 5.3 - Detalhes dos grupos das vigas

Assim como especificado, as vigas do grupo A são vigas sem qualquer tipo de reforço. As vigas do grupo B recebem dois laminados inseridos em seus cobrimentos. As vigas dos grupos $\mathrm{C}$ e $\mathrm{D}$ passam por um processo de retirada de $8 \mathrm{~cm}$ de concreto na face tracionada, para receber o compósito CPM1,5A1C, onde, após a cura, são inseridos os laminados. A diferença entre esses dois grupos é que no grupo $\mathrm{C}$, o comprimento de substituição do 
concreto é a distância entre apoios. Já no grupo $\mathrm{D}$, a reconstituição é realizada apenas nos vãos de cisalhamento.

Ferrari (2007) recomenda a profundidade de $8 \mathrm{~cm}$ porque dessa maneira os estribos ficam expostos, o que os permite funcionar como um elo entre o concreto da viga e o compósito cimentício. Em seu trabalho, não houve sinal de desprendimento dessa ligação, mesmo sem utilizar qualquer tipo de resina para aderir os dois concretos.

Sendo assim, para realizar essa reconstituição da face tracionada, as vigas dos grupos C e D foram marcadas e em seguidas apicoadas com britadeira manual, 14 dias após a concretagem (Figura 5.4). Tomou-se o cuidado de não extrapolar as marcações, embora alguns desvios fossem inevitáveis.

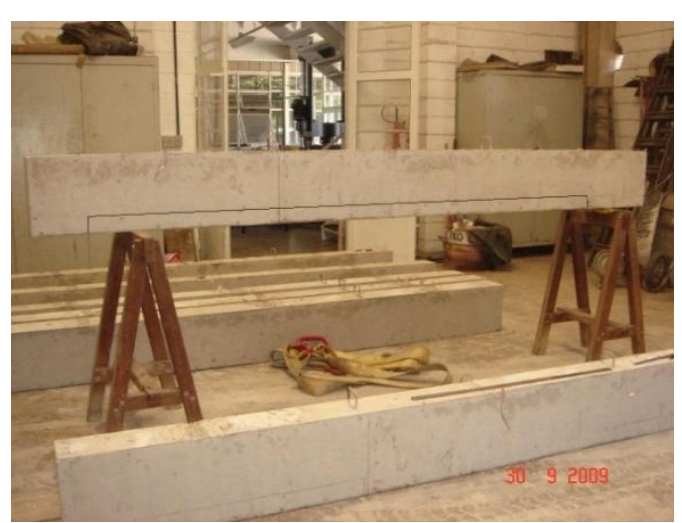

a) viga com marcação

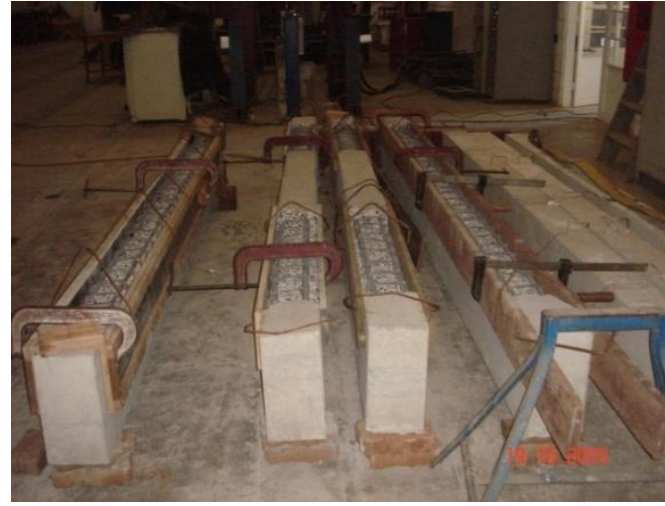

b) vigas apicoadas

Figura 5.4 - Marcação e apicoamento das vigas

O passo seguinte foi a reabilitação das vigas com o compósito cimentício. O concreto foi produzido no Laboratório de Estruturas, segundo a sequêencia já descrita nos capítulos anteriores.

Para permitir a aplicação do compósito, foram colocadas duas fôrmas de madeira nas laterais das vigas, como se observa na Figura 5.4b. A superfície exposta do concreto passou por limpeza com jato de ar e depois de água para eliminar o pó remanescente. Tanto a superfície do concreto como as fôrmas foram molhadas para evitar absorção da água de hidratação do compósito.

Após a viga apresentar superfície seca, o compósito foi adicionado, passando por uma breve vibração, apenas para expulsar o ar aprisionado (Figura 5.5). 


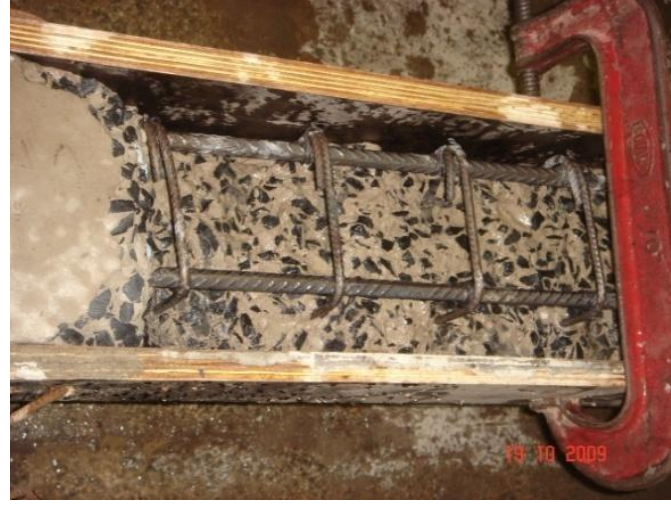

a) processo de limpeza

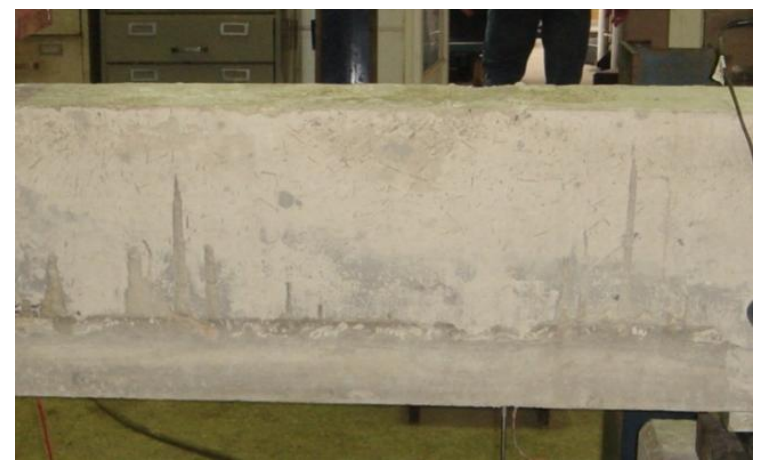

c) aspecto final da reabilitação

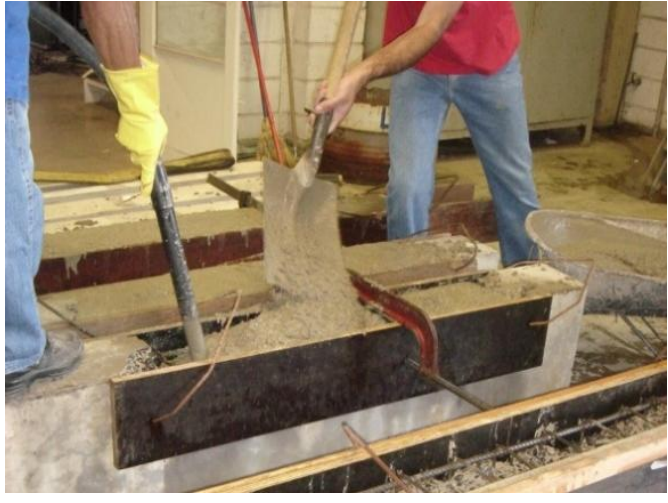

b) processo de reconstituição e vibração

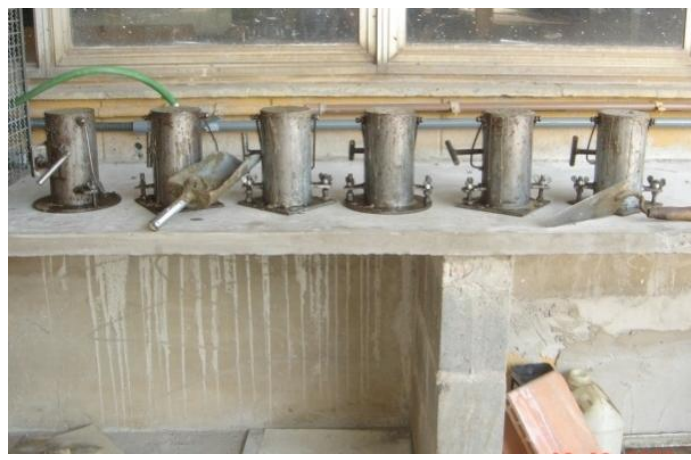

d) corpos de prova

Figura 5.5 - Processo de reabilitação das vigas

Depois de reconstituídas, as vigas permaneceram no interior do laboratório, cobertas por lonas plásticas durante três dias. Seis corpos de prova cilíndricos 10 x $20 \mathrm{~cm}$ foram moldados para ensaios de caracterização e permaneceram em câmara úmida até a data do ensaio principal.

Assim como Ferrari (2007), nesse trabalho não houve uso de qualquer tipo de resina para unir o compósito ao concreto da viga, acreditando que os estribos, associados à grande rugosidade proporcionada pelo apicoamento, fossem suficientes para impedir o descolamento da junção.

Uma semana depois, iniciaram-se os procedimentos para inserção dos laminados nas vigas.

Com base nas conclusões do trabalho realizado por Bonaldo, Barros e Lourenço (2007), descrito no Capítulo 2, os laminados foram posicionados de tal forma que a distância entre os eixos das armaduras longitudinais fosse dividida em três partes iguais, isto é, a 
distância entre o laminado e a armadura mais próxima fosse igual à distância entre os laminados, conforme Figura 5.6:

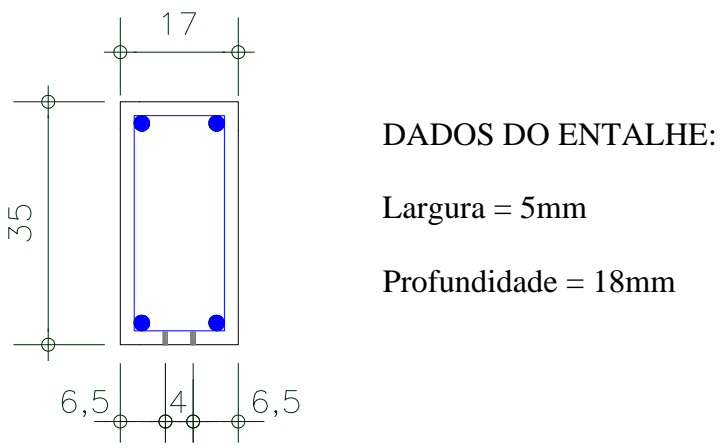

Figura 5.6 - Posicionamento dos laminados na seção transversal da viga

Assim como no ensaio de aderência (Capítulo 4), o entalhe foi demarcado na viga e executado com auxílio de dois discos de corte por meio de via úmida, ficando as aberturas com aproximadamente $5 \mathrm{~mm}$ de largura e $18 \mathrm{~mm}$ de profundidade (Figura 5.7):

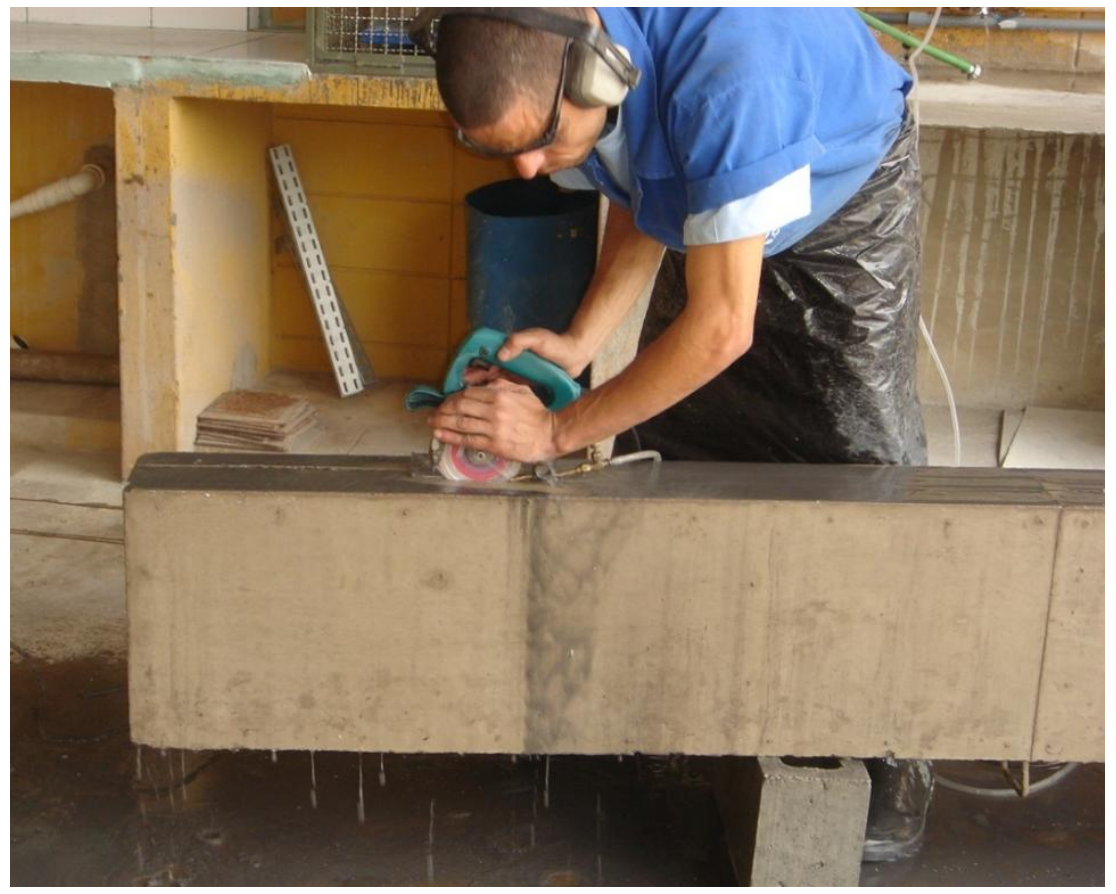

Figura 5.7 - Execução do entalhe por meio de via úmida

$\mathrm{Na}$ região onde se posicionavam os extensômetros dos laminados, o entalhe teve de ficar mais largo. 
Após secagem na área externa do laboratório, as aberturas foram limpas com jato de ar e estopa embebida em álcool.

Enquanto isso, os laminados foram cortados e limpos com álcool. O comprimento foi $2 \mathrm{~cm}$ maior que o comprimento das vigas, para fixação de chapa e cantoneira metálica, que servem de base para a medição do deslizamento do laminado em relação à viga, conforme proposto no Capítulo 4.

Para fixação do laminado no entalhe, foi utilizada a resina epóxi bi-componente Sikadur ${ }^{\circledR} 30$ nas proporções indicadas pelo fabricante:

Parte A : Parte B = 3: 1 em peso ou volume

Nota-se que houve mudança da resina com relação à utilizada no ensaio de aderência e o motivo será esclarecido na seção 5.4.4.

A mistura realizada manualmente foi baseada no peso dos componentes e perdurou por três minutos. $\mathrm{O}$ aspecto final apresentou consistência satisfatória para aplicação na região inferior da viga em uma situação real. A textura da mistura pode ser observada na Figura 5.8:

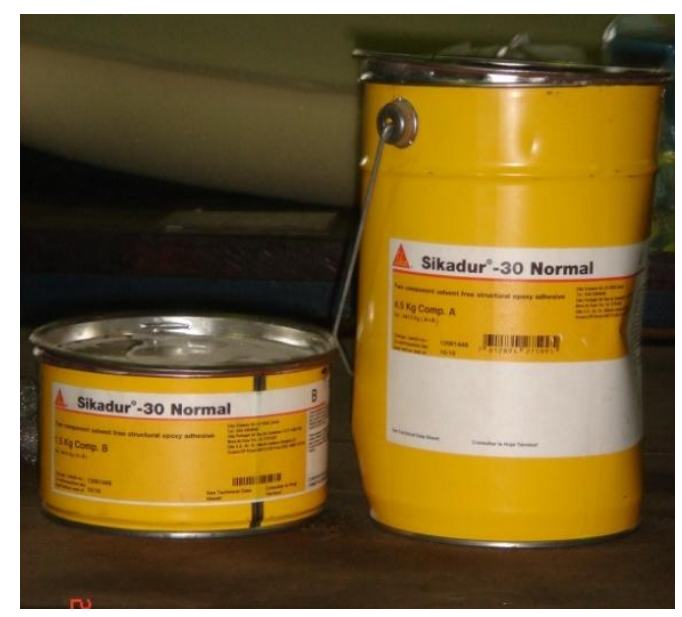

a) componentes $\mathrm{A}$ e B da resina

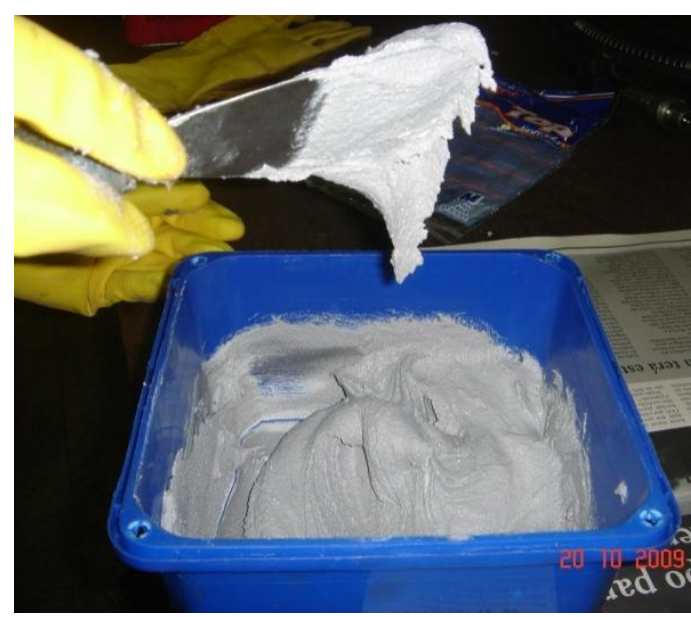

b) consistência da resina após mistura

Figura 5.8 - Mistura da resina

A ficha técnica do produto informa que quanto mais elevada for a temperatura ambiente e maior a quantidade de resina preparada, menor é o tempo de disponível para 
aplicação do adesivo. Por esses motivos e devido à falta de prática da autora, na primeira viga foi preparada resina na quantidade necessária para aplicação dos dois laminados. Porém, a partir da metade da aplicação do segundo laminado, a resina começou a endurecer, dificultando o trabalho. Para não haver diferença na resina, continuou-se a aplicação, mas nas demais vigas a resina foi preparada na quantidade para inserção de apenas um laminado por vez.

A aplicação da resina consiste em sua distribuição nas duas faces da abertura do entalhe utilizando uma espátula, e em seguida o mesmo procedimento é realizado nas duas faces do laminado. Esse processo garante que haverá aderência em toda extensão do reforço.

Após a colocação do laminado no entalhe, o excesso de resina é retirado e utilizado para dar o acabamento final à viga.

Os laminados, assim como as vigas, receberam marcação do comprimento de ancoragem. Mais especificamente, a resina foi aplicada até $5 \mathrm{~cm}$ do eixo do apoio.

A Figura 5.9 apresenta o processo de reforço das vigas:

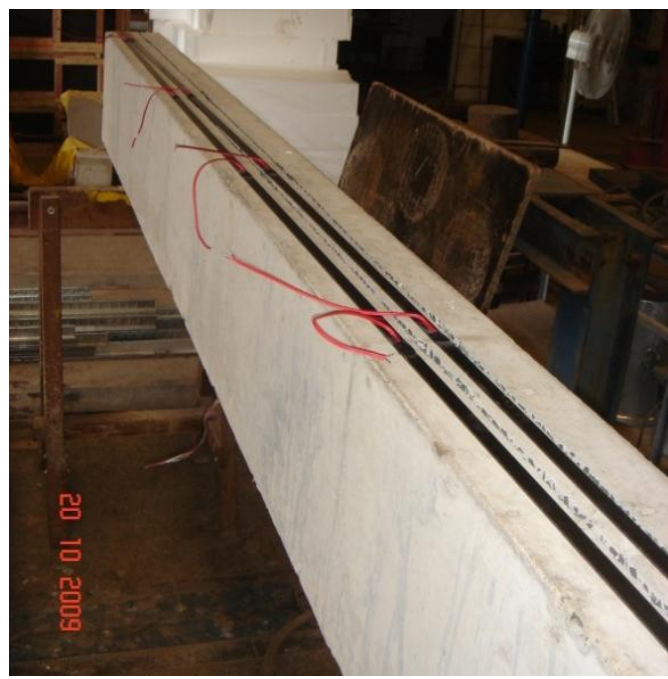

a) posicionamento do laminado ao lado do entalhe para marcação do comprimento de ancoragem

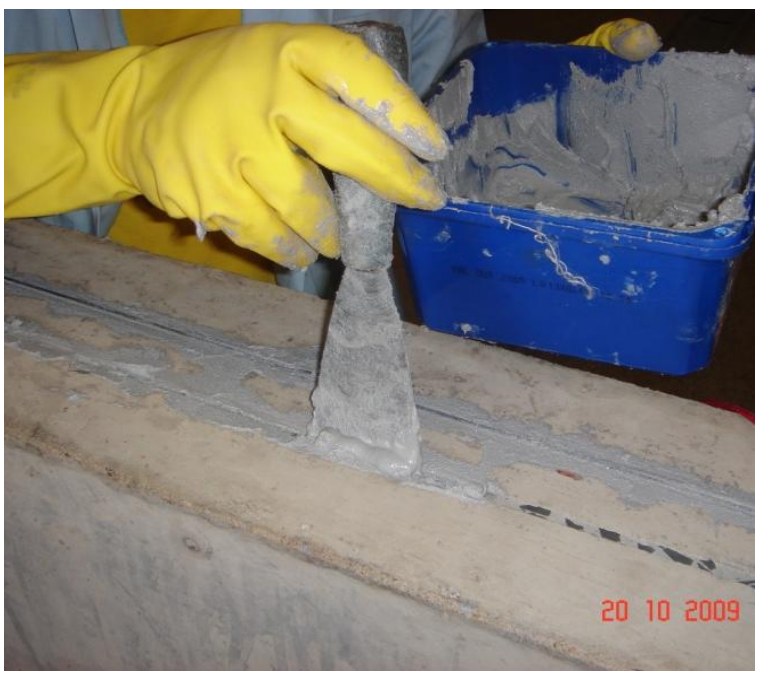

b) aplicação da resina no entalhe 


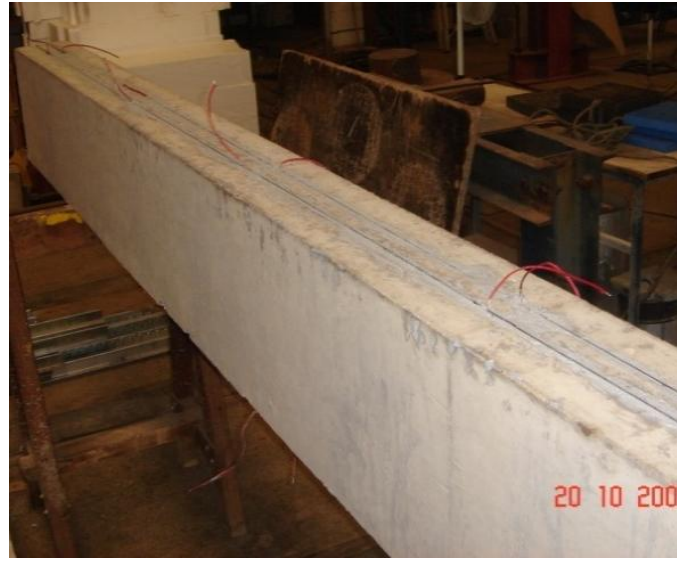

c) aspecto final da viga reforçada

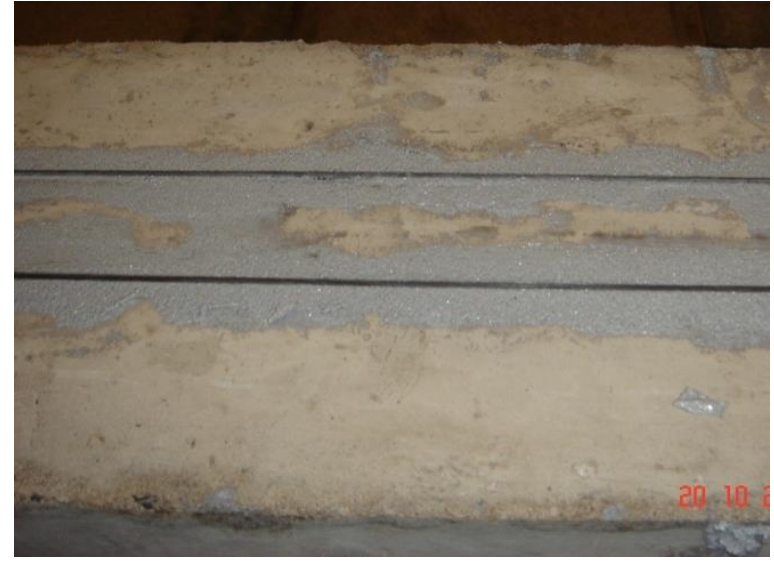

d) detalhe do acabamento da viga

Figura 5.9 - Processo de reforço

Após o término do reforço, as vigas tiveram sete dias para cura da resina, conforme sugere o fabricante para obtenção dos melhores resultados.

\subsection{Configuração do ensaio}

O ensaio das vigas principais foi realizado no Laboratório de Estruturas da Escola de Engenharia de São Carlos com obtenção de dados como: carga aplicada ao longo do tempo, deformações no aço, concreto e laminado, deslocamentos verticais da viga e deslocamento horizontal do laminado.

O esquema estático do ensaio à flexão em quatro pontos pode ser observado na Figura 5.10:

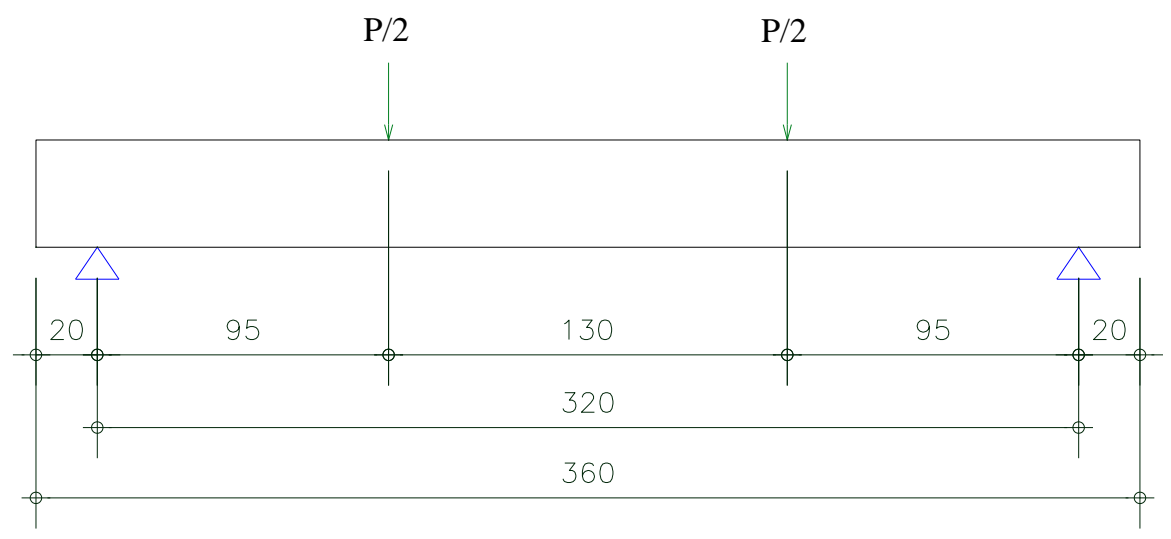

Figura 5.10 - Esquema estático do ensaio das vigas principais 
Para aplicação da carga foi utilizado um atuador servo-hidráulico da marca Instron com capacidade para $500 \mathrm{kN}$ e curso de $150 \mathrm{~mm}$, a uma velocidade de $0,005 \mathrm{~mm} / \mathrm{s}$ de deslocamento do pistão. O sistema de aquisição de dados foi o System 5000 da marca Vishay.

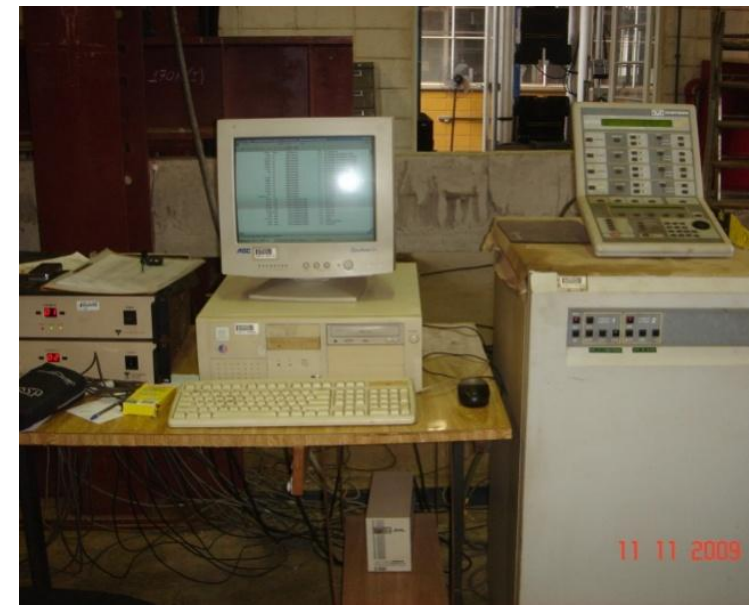

a) sistema de aquisição de dados

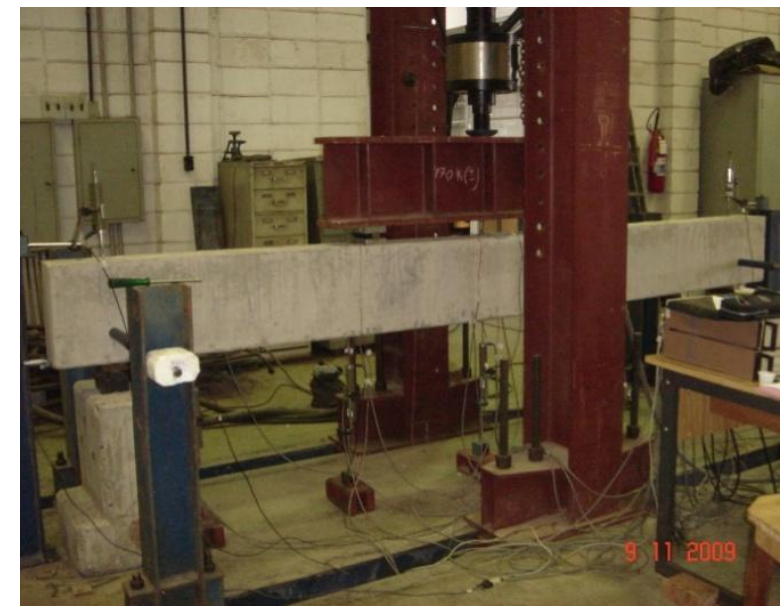

b) situação esquemática do ensaio

Figura 5.11 - Esquema geral do ensaio à flexão

Os apoios foram rotulados. ambos permitindo o deslocamento horizontal da viga. Em contrapartida, outro dispositivo foi acrescentado nos pontos de aplicação de carga para impedir a translação da viga (Figura 5.12):

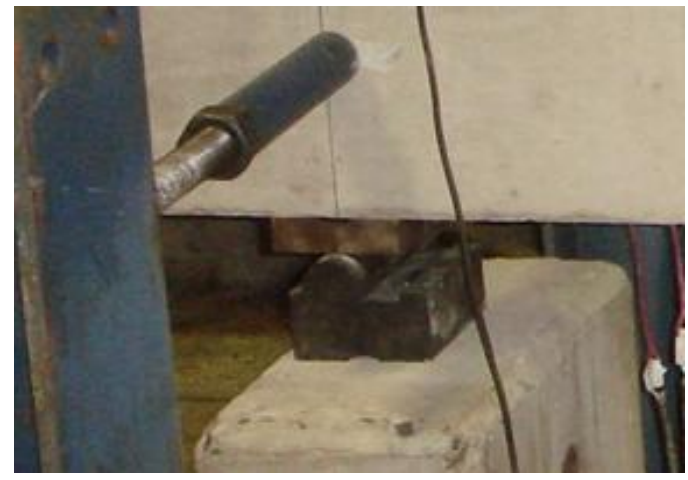

a) dispositivo de apoio

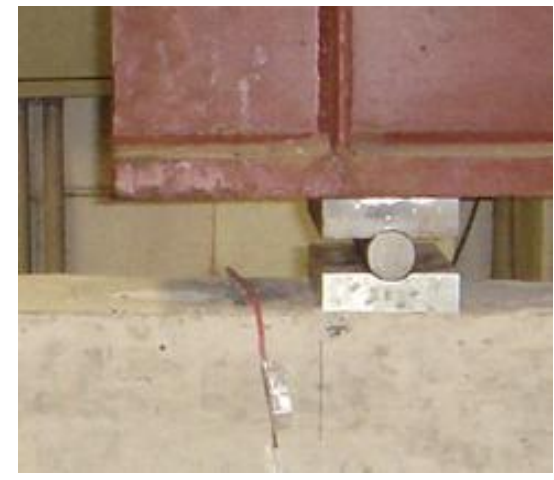

b) dispositivo para aplicação da carga

Figura 5.12 - Esquema geral do ensaio à flexão

Foram utilizados cinco transdutores para medição do deslocamento vertical da viga, um transdutor para medição do deslocamento horizontal do laminado, dois extensômetros elétricos para medir a deformação do concreto, três extensômetros elétricos para medir a 
deformação de cada barra de aço e mais cinco extensômetros elétricos para medir a deformação de cada laminado.

O posicionamento desses equipamentos na viga e suas especificações podem ser vistos na Figura 5.13 e na Tabela 5.2 respectivamente:

\title{
INSTRUMENTAÇÃO
}

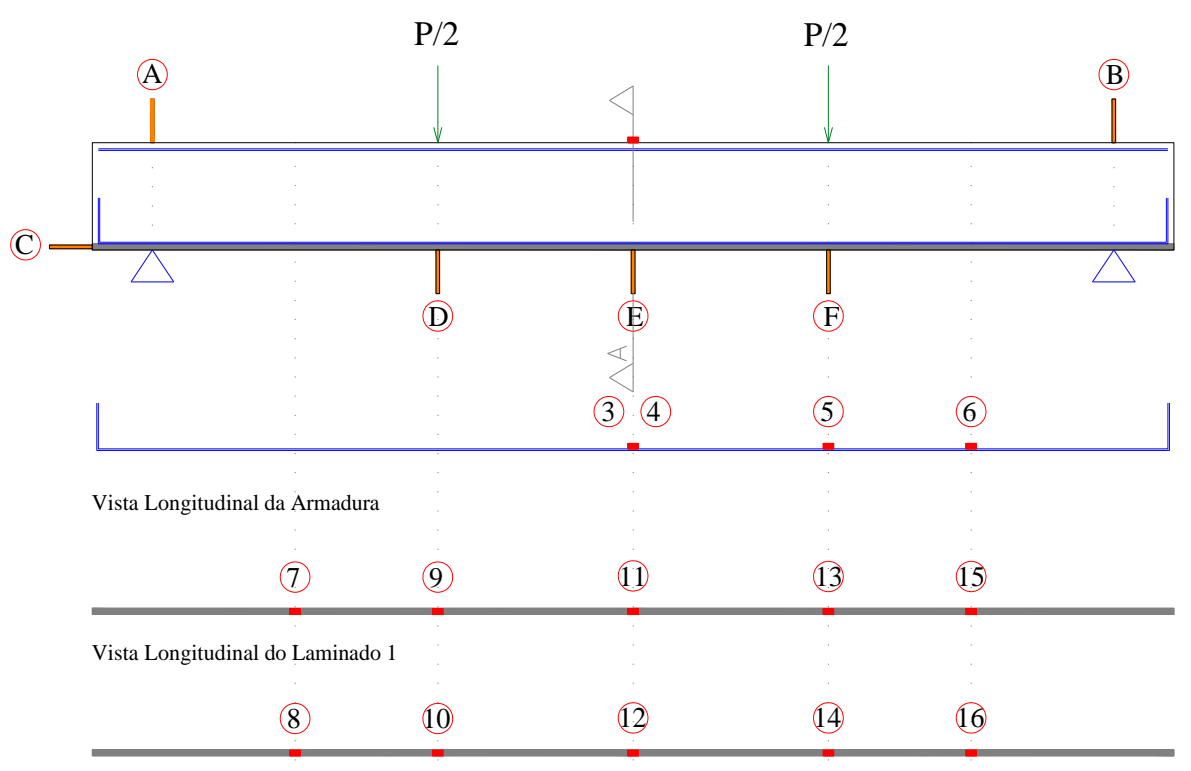

Vista Longitudinal do Laminado 2

LEGENDA

Ponto de aplicação de carga

- Extensômetro

Corte A

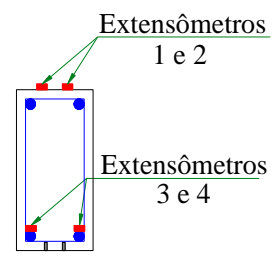

111

\author{
.
}




\begin{tabular}{|c|c|c|c|}
\hline & $\mathrm{D}$ & $\begin{array}{l}\text { Ponto de aplicação da carga } \\
\text { (vão de cisalhamento) }\end{array}$ & $\begin{array}{l}\text { Marca Kyowa, com curso } \\
\text { de } 100 \mathrm{~mm} \text { e sensibilidade } \\
\text { de } 0,02 \mathrm{~mm}\end{array}$ \\
\hline & $\mathrm{E}$ & Meio do vão & $\begin{array}{l}\text { Marca Kyowa, com curso } \\
\text { de } 100 \mathrm{~mm} \text { e sensibilidade } \\
\text { de } 0,02 \mathrm{~mm}\end{array}$ \\
\hline & $\mathrm{F}$ & $\begin{array}{l}\text { Ponto de aplicação da carga } \\
\text { (vão de cisalhamento) }\end{array}$ & $\begin{array}{l}\text { Marca Kyowa, com curso } \\
\text { de } 100 \mathrm{~mm} \text { e sensibilidade } \\
\text { de } 0,02 \mathrm{~mm}\end{array}$ \\
\hline \multirow{11}{*}{ Extensômetro } & 1 & Concreto & $\begin{array}{l}\text { Marca Kyowa, modelo } \\
\text { KFG-5-120-C1-11 (base } \\
\text { de medida de } 5 \mathrm{~mm} \text { ) }\end{array}$ \\
\hline & 2 & Concreto & $\begin{array}{l}\text { Marca Kyowa, modelo } \\
\text { KFG-5-120-C1-11 (base } \\
\text { de medida de } 5 \mathrm{~mm} \text { ) }\end{array}$ \\
\hline & 3 & Armadura Positiva & $\begin{array}{l}\text { Marca Kyowa, modelo } \\
\text { KFG-10-120-C1-11 (base } \\
\text { de medida de } 10 \mathrm{~mm} \text { ) }\end{array}$ \\
\hline & 4 & Armadura Positiva & $\begin{array}{l}\text { Marca Kyowa, modelo } \\
\text { KFG-10-120-C1-11 (base } \\
\text { de medida de } 10 \mathrm{~mm} \text { ) }\end{array}$ \\
\hline & 5 & Armadura Positiva & $\begin{array}{l}\text { Marca Kyowa, modelo } \\
\text { KFG-10-120-C1-11 (base } \\
\text { de medida de } 10 \mathrm{~mm} \text { ) }\end{array}$ \\
\hline & 6 & Armadura Positiva & $\begin{array}{l}\text { Marca Kyowa, modelo } \\
\text { KFG-10-120-C1-11 (base } \\
\text { de medida de } 10 \mathrm{~mm} \text { ) }\end{array}$ \\
\hline & $7 / 8$ & $\begin{array}{l}\text { Laminado (Final da zona de } \\
\text { ancoragem) }\end{array}$ & $\begin{array}{l}\text { Marca Kyowa, modelo } \\
\text { KFG-10-120-C1-11 (base } \\
\text { de medida de } 10 \mathrm{~mm} \text { ) }\end{array}$ \\
\hline & $9 / 10$ & $\begin{array}{c}\text { Laminado (Ponto de aplicação } \\
\text { de carga) }\end{array}$ & $\begin{array}{l}\text { Marca Kyowa, modelo } \\
\text { KFG-10-120-C1-11 (base } \\
\text { de medida de } 10 \mathrm{~mm} \text { ) }\end{array}$ \\
\hline & $11 / 12$ & Laminado (Meio do vão) & $\begin{array}{l}\text { Marca Kyowa, modelo } \\
\text { KFG-10-120-C1-11 (base } \\
\text { de medida de } 10 \mathrm{~mm} \text { ) }\end{array}$ \\
\hline & $13 / 14$ & $\begin{array}{c}\text { Laminado (Ponto de aplicação } \\
\text { de carga) }\end{array}$ & $\begin{array}{l}\text { Marca Kyowa, modelo } \\
\text { KFG-10-120-C1-11 (base } \\
\text { de medida de } 10 \mathrm{~mm} \text { ) }\end{array}$ \\
\hline & $15 / 16$ & $\begin{array}{l}\text { Laminado (Final da zona de } \\
\text { ancoragem) }\end{array}$ & $\begin{array}{l}\text { Marca Kyowa, modelo } \\
\text { KFG-10-120-C1-11 (base } \\
\text { de medida de } 10 \mathrm{~mm} \text { ) }\end{array}$ \\
\hline
\end{tabular}


Abaixo encontra-se em detalhe, a fixação do transdutor para medição do deslocamento horizontal do laminado:

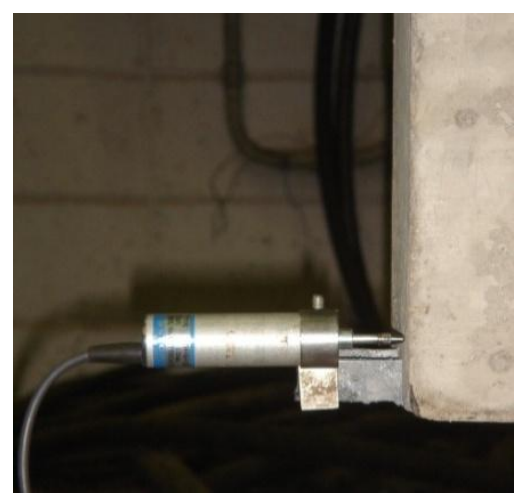

Figura 5.14 - Fixação do transdutor para medição do deslocamento do laminado

\subsection{Caracterização dos materiais}

\subsubsection{Concreto}

Devido ao volume de concreto para moldagem das oito vigas, o material foi adquirido de uma usina da região, sob especificação de resistência à compressão de $30 \mathrm{MPa}$. Além das vigas, foram moldados seis corpos de prova cilíndricos 10 x $20 \mathrm{~cm}$ para ensaios à tração diametral e à compressão, com obtenção do módulo de elasticidade. As normas utilizadas foram a ABNT NBR 5739 (1994), ABNT NBR 7222 (1994) e ABNT NBR 8522 (2003), respectivamente.

Um dia depois de moldados, os corpos de prova foram retirados das fôrmas e levados para câmara úmida onde permaneceram por 50 dias. Os resultados estão apresentados na Tabela 5.3:

Tabela 5.3 - Resultados do ensaio de caracterização do concreto usinado

\begin{tabular}{c|c|c|c}
\hline Corpo de Prova & $\mathbf{f}_{\mathbf{c}}(\mathbf{M P a})$ & $\mathbf{f}_{\mathbf{c t}}(\mathbf{M P a})$ & $\mathbf{E}_{\mathbf{c}}(\mathbf{G P a})$ \\
\hline 1 & 33,99 & 2,55 & 44,30 \\
\hline 2 & 32,47 & 3,06 & 39,49 \\
\hline 3 & 28,03 & 3,17 & 37,46 \\
\hline Média & $\mathbf{3 1 , 5 0}$ & $\mathbf{2 , 9 3}$ & $\mathbf{4 0 , 4 2}$ \\
\hline
\end{tabular}




\subsubsection{Compósito cimentício}

Para reconstituir a face inferior das vigas dos grupos $\mathrm{C}$ e $\mathrm{D}$, buscando o aumento da capacidade de carga do reforço, foi utilizado o compósito cimentício proposto no Capítulo 3. O consumo de material para produção de $0,157 \mathrm{~m}^{3}$ de compósito pode ser visto na Tabela 5.4:

Tabela 5.4 - Consumo de material para produção do compósito cimentício

\begin{tabular}{c|c|c}
\hline \multicolumn{3}{c}{ Traço $\mathbf{1}: \mathbf{2 , 3 0}: \mathbf{1 , 7 0}: \mathbf{0 , 4 8}$} \\
\hline Material & Consumo $\left(\mathbf{k g} / \mathbf{m}^{\mathbf{3}}\right)$ & Consumo $(\mathbf{k g})$ \\
\hline Cimento CPV ARI & 443,0 & 69,54 \\
\hline Areia & 1018,9 & 159,94 \\
\hline Brita 0 & 753,1 & 118,22 \\
\hline Água & 212,6 & 33,38 \\
\hline Fibra de aço FS8 Wirand & - & 18,49 \\
\hline Microfibra de aço & - & 12,32 \\
\hline Superplastificante Glenium 51 & - & 0,35 \\
\hline
\end{tabular}

O processo de mistura, já discutido nos capítulos anteriores, seguiu a seguinte sequência: mistura rápida de areia e brita, acréscimo de cimento, parte da água, e uma nova mistura. O restante da água, as fibras e microfibras de aço e finalmente a adição de superplastificante e uma última mistura que durou três minutos.

Foram moldados seis corpos de prova cilíndricos 10 × $20 \mathrm{~cm}$ para ensaios de caracterização realizados após sete dias de cura. Três corpos de prova foram rompidos à tração diametral, conforme a ABNT NBR 5739 (1994), e os outros três rompidos à compressão, segundo a ABNT NBR 7222 (1994) com obtenção do módulo de elasticidade conforme a ABNT NBR 8522 (2003).

A Tabela 5.5 apresenta os resultados dos ensaios:

Tabela 5.5 - Resultados do ensaio de caracterização do compósito cimentício

\begin{tabular}{c|c|c|c}
\hline Corpo de Prova & $\mathbf{f}_{\mathbf{c}}(\mathbf{M P a})$ & $\mathbf{f}_{\mathbf{c t}}(\mathbf{M P a})$ & $\mathbf{E}_{\mathbf{c}}(\mathbf{G P a})$ \\
\hline 1 & 48,58 & 5,02 & 30,66 \\
\hline 2 & 45,57 & 4,39 & 33,39 \\
\hline 3 & 49,70 & 4,41 & 35,18 \\
\hline Média & $\mathbf{4 7 , 9 5}$ & $\mathbf{4 , 6 1}$ & $\mathbf{3 3 , 0 8}$ \\
\hline
\end{tabular}




\subsubsection{Laminado}

O material foi adquirido da empresa Rogertec-Rogermat, que comercializa o produto pelo nome de Fita MFC. Como o material utilizado nesse ensaio é de lote diferente daquele caracterizado no Capítulo 4, houve necessidade de novos ensaios.

Os ensaios seguiram as recomendações da ASTM D3039/D 3039M (2008). Para isso foram utilizadas três amostras com $1 \mathrm{~m}$ de comprimento cada, preparadas através da fixação de tiras em suas extremidades. Essas tiras eram laminados com $15 \mathrm{~cm}$ fixadas com cola instantânea.

Em uma das faces do laminado, e no meio de seu comprimento, foi instalado um extensômetro elétrico. Na outra face e no mesmo local, foi instalado um transdutor de deslocamento.

Os ensaios foram realizados na máquina servo-hidráulica da marca Instron com sistema de aquisição de dados System 5000 da marca Vishay. A Figura 5.15 apresenta um dos corpos de prova antes e após a ruptura:

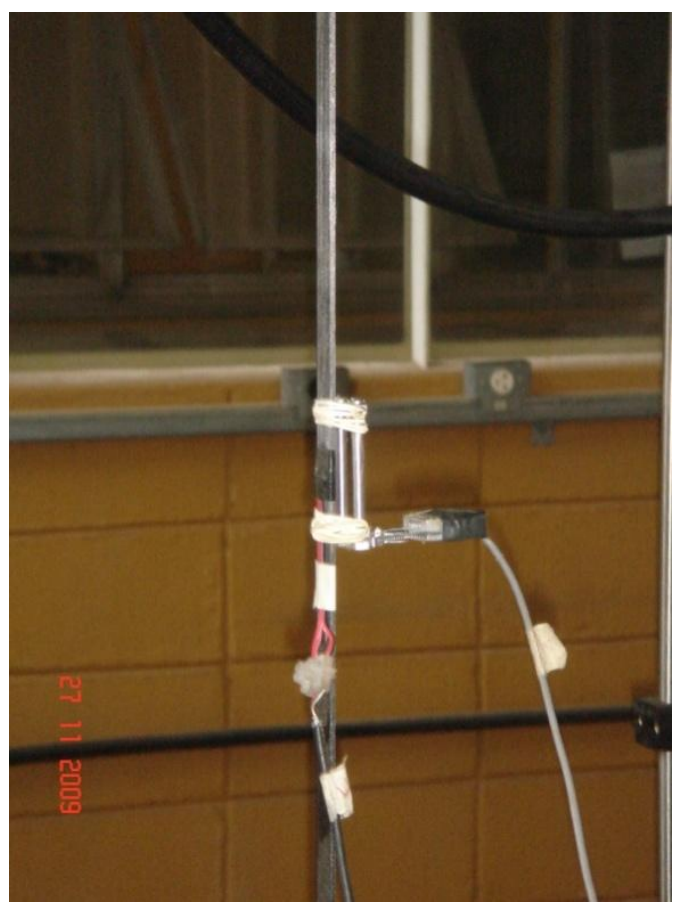

a) corpo de prova antes da ruptura

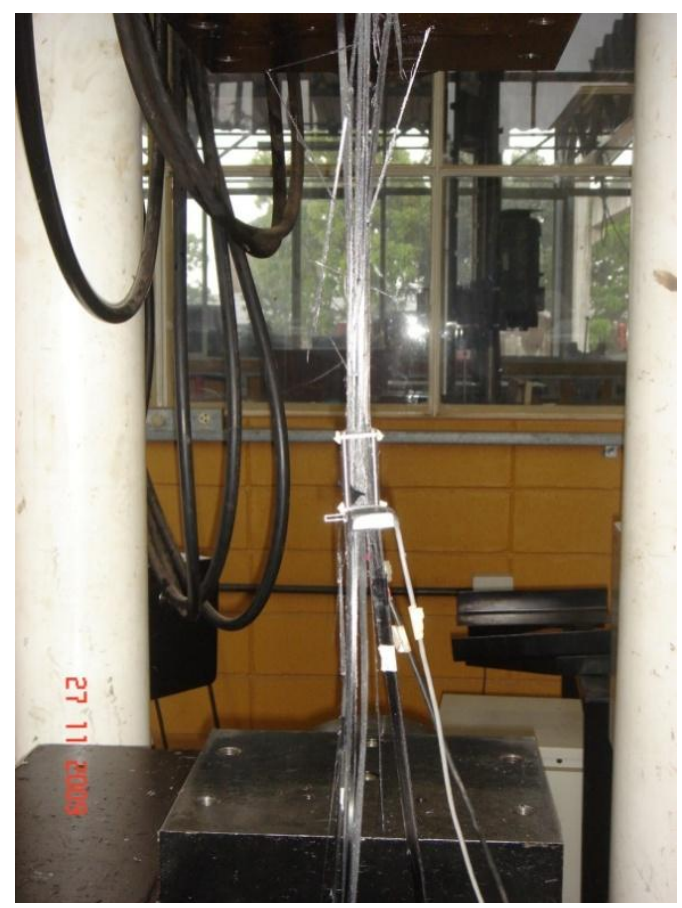

b) corpo de prova após ruptura

Figura 5.15 - Ensaio de caracterização dos laminados 
A Figura 5.16 apresenta o gráfico plotado com os dados obtidos nos ensaios:

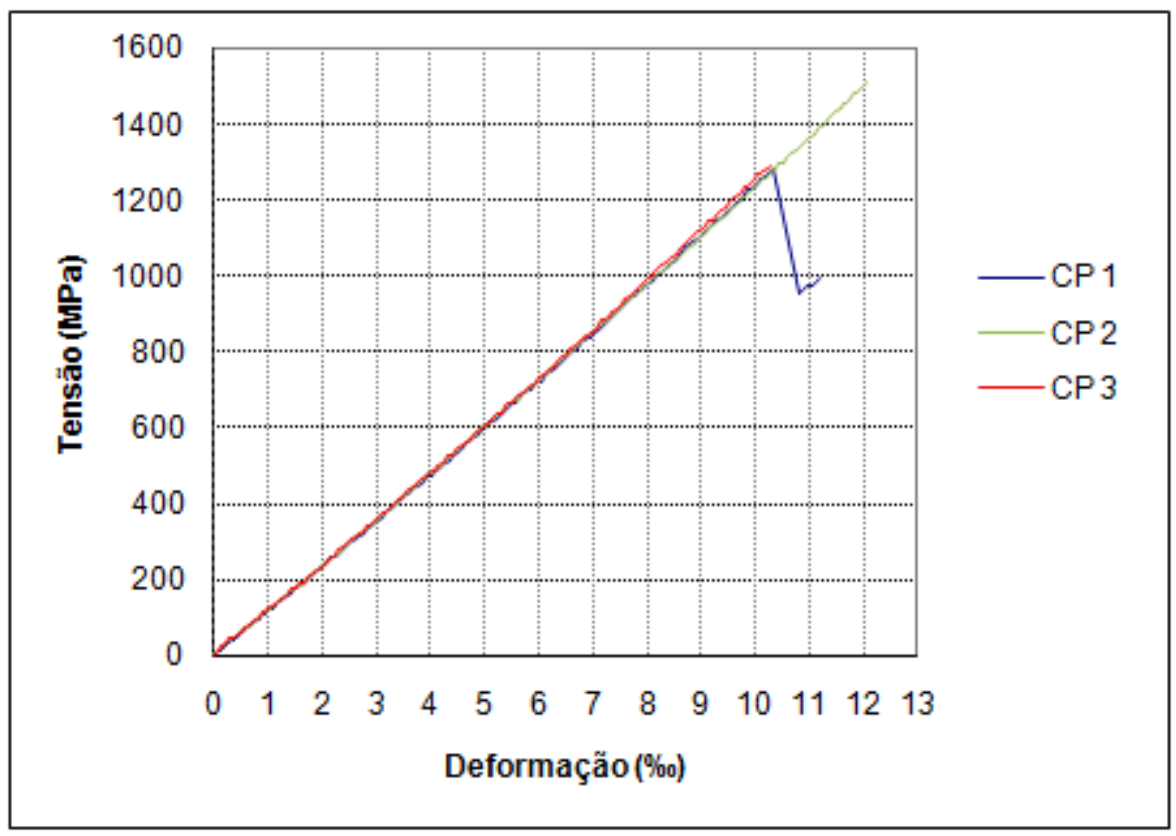

Figura 5.16 - Gráfico tensão x deformação dos três corpos de prova

A Tabela 5.6 apresenta os resultados da caracterização dos corpos de prova. Para maiores esclarecimentos sobre a forma com que os resultados foram obtidos, recomenda-se a leitura da seção 4.2.2.

Tabela 5.6 - Resultados dos ensaios de caracterização dos laminados

\begin{tabular}{|c|c|c|c|c|}
\hline CP & $\begin{array}{c}\text { Força Máxima } \\
(\mathbf{k N})\end{array}$ & $\begin{array}{c}\text { Tensão Máxima } \\
\text { (MPa) }\end{array}$ & $\begin{array}{c}\text { Deformação } \\
\text { última }\left(\xi_{\mathrm{u}}\right) \\
(\%)\end{array}$ & $\begin{array}{c}\text { Módulo de } \\
\text { Elasticidade } \\
\text { (GPa) }\end{array}$ \\
\hline 1 & 43,11 & 1286 & 1,03 & 117 \\
\hline 2 & 50,74 & 1513 & 1,21 & 119 \\
\hline 3 & 43,26 & 1290 & 1,03 & 119 \\
\hline Média & 45,70 & 1363 & 1,09 & 118 \\
\hline
\end{tabular}

Observa-se que os resultados foram inferiores aos obtidos no primeiro ensaio de caracterização (Capítulo 4) e ainda menores que os fornecidos pelo fabricante. 
As dimensões do laminado, obtidas com auxílio de um paquímetro digital em vinte pontos aleatórios das amostras, resultaram em 2,11 mm de espessura e 15,89 mm de largura.

\subsubsection{Resina}

Conforme esclarecido no Capítulo 4, a resina indicada pelo fabricante para uso em conjunto com o laminado reforçado com fibra de carbono é o Sikadur ${ }^{\circledR}$ 30. Porém, na ocasião do ensaio de aderência, a informação foi obtida após a conclusão do reforço dos corpos de prova. Portanto, no ensaio das vigas principais foi utilizada a resina correta, com a intenção de buscar resultados ainda melhores que aqueles apresentados no Capítulo 4.

Os dados fornecidos pelo fabricante para a resina bi-componente Sikadur ${ }^{\circledR} 30$ estão apresentados na Tabela 5.7:

Tabela 5.7 - Propriedades da resina Sikadur ${ }^{\circledR} 30$ fornecidas pelo fabricante

\begin{tabular}{c|c|c|c}
\hline $\begin{array}{c}\text { Resistência à } \\
\text { Flexotração } \\
(\mathbf{M P a})\end{array}$ & $\begin{array}{c}\text { Resistência à } \\
\text { Aderência } \\
(\mathbf{M P a})\end{array}$ & Módulo de Elasticidade & Cisalhamento \\
\hline 28 & $4^{*}$ & $(\mathbf{M P a})$ & $(\mathbf{M P a})$ \\
\hline
\end{tabular}

Falha no concreto

Juvandes (1999) realizou ensaios de caracterização com o Sikadur ${ }^{\circledR} 30$ e os resultados, comparados aos dados fornecidos pelo fabricante, podem ser vistos na Tabela 5.8:

Tabela 5.8 - Resultados do ensaio de caracterização com o Sikadur® 30 (Adaptado de JUVANDES, 1999, p. 3.57)

\begin{tabular}{l|c|c}
\hline \multicolumn{1}{c}{ Principais Propriedades } & \multicolumn{2}{c}{ Sikadur $^{\circledR}$ 30 } \\
\cline { 2 - 3 }$(\mathbf{M P a})$ & Ensaios & Fabricante \\
\hline Resistência à compressão $(\mathrm{MPa})$ & $80-90$ & $75-100$ \\
\hline Aderência adesivo-concreto $(\mathrm{MPa})$ & $>2$ & $>4$ \\
\hline Resistência à tração $(\mathrm{MPa})$ & - & $20-30$ \\
\hline Resistência à flexo-tração $(\mathrm{MPa})$ & $50-70$ & 15 \\
\hline Resistência ao corte $(\mathrm{MPa})$ & - & 12,8 \\
\hline Módulo de elasticidade $(\mathrm{GPa})$ & 12,5 & - \\
\hline
\end{tabular}




\begin{tabular}{l|c|c}
\hline Extensão na ruptura (\%) & $3,0-5,0$ & - \\
\hline Coeficiente de expansão $\left(-10^{\circ} \mathrm{C}\right.$ a $\left.40^{\circ} \mathrm{C}\right)$ & - & $9 \times 10^{-5} /{ }^{\circ} \mathrm{C}$ \\
\hline Retração (\%) & - & 0,04 \\
\hline Massa volumétrica $\left(\mathrm{kN} / \mathrm{m}^{3}\right)$ & 17,6 & 17,3 \\
\hline Temp. transição vítrea $-\mathrm{Tg}\left({ }^{\circ} \mathrm{C}\right)$ & $49-58$ & 62 \\
\hline Temperatura crítica $-\mathrm{Tc}\left({ }^{\circ} \mathrm{C}\right)$ & $33-45$ & $42-52$ \\
\hline Tempo de utilização $(\mathrm{min})$ & - & $40\left(\mathrm{a} \mathrm{35}{ }^{\circ} \mathrm{C}\right)$ \\
\hline
\end{tabular}

De uma maneira geral, os resultados não diferiram muito dos indicados pelo fabricante.

Juvandes (1999) também realizou ensaios de "pull-off" em prismas utilizando o Sikadur ${ }^{\circledR} 30$ e os resultados da resistência à tração perpendicular à ligação concreto-resina foram superiores a $3 \mathrm{MPa}$, com rompimento do concreto.

Esses resultados interessantes aumentam a confiança no produto e permitem justificar a troca da resina no ensaio das vigas principais.

\subsection{Resultados e Análises}

\subsubsection{Modo de ruptura}

Pensando na segurança dos equipamentos e das pessoas envolvidas na realização dos ensaios, nenhuma viga atingiu a ruptura. Ao verificar que a deformação do aço, assim como do laminado aproximavam-se de seus limites, os ensaios eram paralisados. Nesse período não houve, em qualquer viga, sinal de destacamento do laminado ou separação entre o concreto da viga e o compósito cimentício da região reconstituída. Isso indica que a rugosidade proporcionada pelo apicoamento, somada aos estribos existentes na viga, é suficiente para integrar as duas fases de concreto sem a necessidade de produtos específicos para aderência. O mesmo comportamento foi observado no trabalho de Ferrari (2007). Embora a seção da viga, comum a ambos os trabalhos, não atenda às recomendações do CEB - Bulletin d'Information 162, com relação às tensões cisalhantes solicitantes e resistentes em juntas de concreto, o modelo despreza a contribuição da armadura transversal existente. Com isso os valores encontrados pelo modelo ficam subestimados. 
As vigas de referência tiveram excessiva deformação da armadura longitudinal, com deformação do concreto comprimido inferior ao limite estabelecido pela ABNT NBR 6118 (2003), que é de 3,5\%o. Essas características garantiram o comportamento da viga no domínio 2 de dimensionamento, assim como previsto.

Sem qualquer tipo de reforço, as vigas de referência tiveram formação de muitas fissuras, que rapidamente se propagaram, como mostra a Figura 5.17:

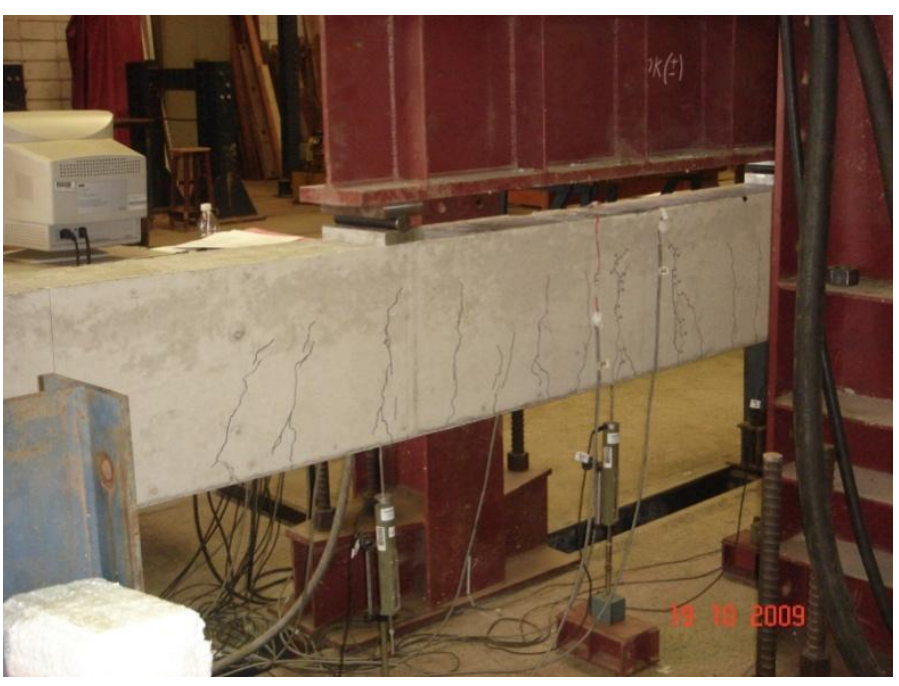

a) aspecto da distribuição das fissuras

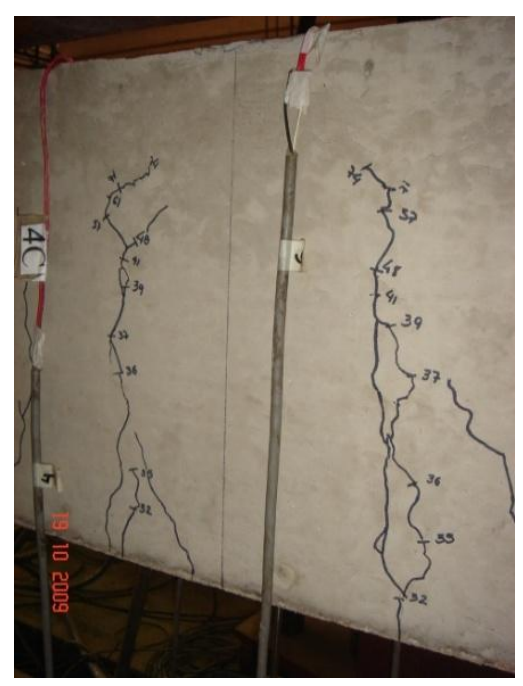

b) fissuras no meio do vão

Figura 5.17 - Detalhe da fissuração da viga de referência

Em todas as vigas, incluindo as de referência, as fissuras iniciaram-se primeiramente no trecho entre os pontos de aplicação de carga e depois nos trechos entre a aplicação de carga e o apoio. Nessa segunda região, a maioria das fissuras era decorrente de esforços cisalhantes.

As vigas dos grupos B e D apresentaram grande quantidade de fissuras, porém com menores aberturas em comparação com as das vigas de referência. Fissuras de menores intensidades foram observadas nas vigas do grupo C. Embora numerosas, as fissuras nessas vigas muitas vezes iniciaram, mas não se propagaram. Isso permite concluir que o compósito cimentício, na região de maior propagação de fissuras (meio do vão) auxilia no controle de sua formação e propagação.

Independentemente do sistema de ancoragem utilizado, pode-se notar que o reforço com laminado, mesmo realizado da forma mais simples (grupo B), limita o processo de fissuração das vigas em comparação com as vigas de referência. 
A Figura 5.18 mostra o aspecto das vigas dos grupos B, C e D:

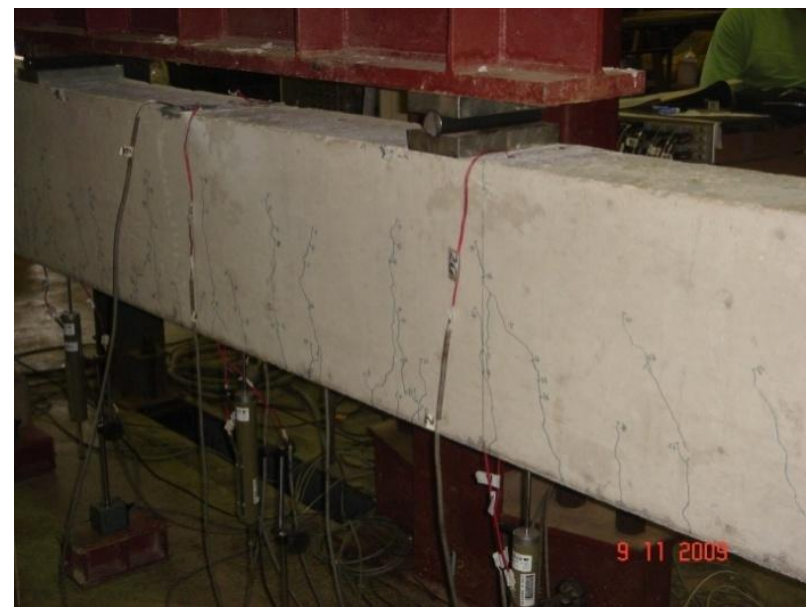

a) aspecto da distribuição das fissuras na viga do grupo B

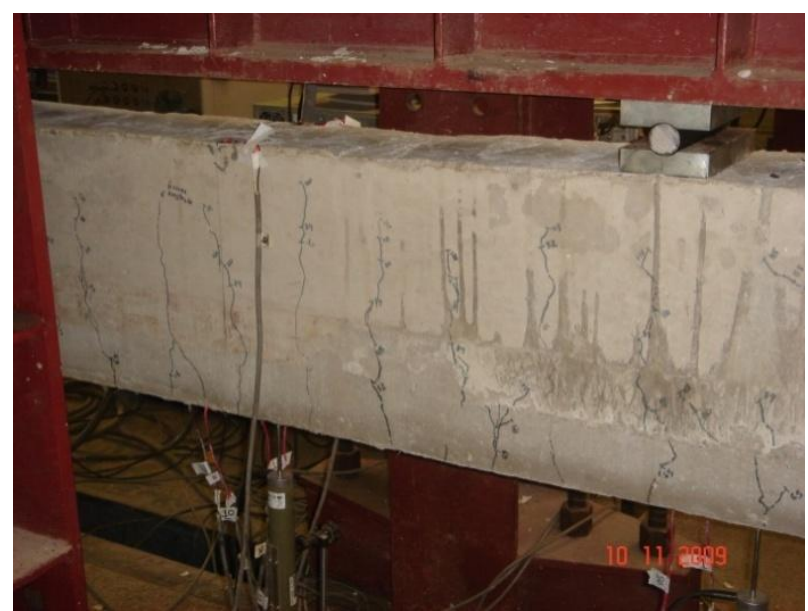

c) aspecto da distribuição das fissuras na viga do grupo C

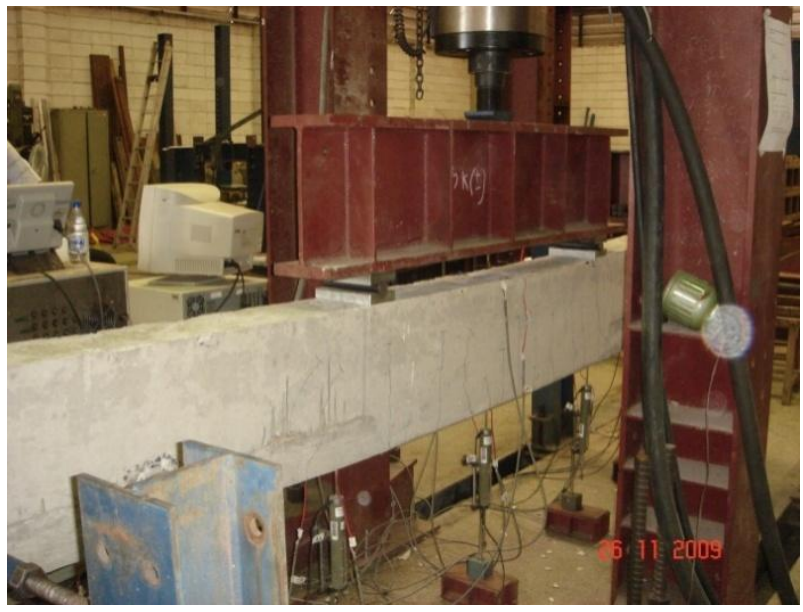

e) aspecto da distribuição das fissuras na viga do grupo D

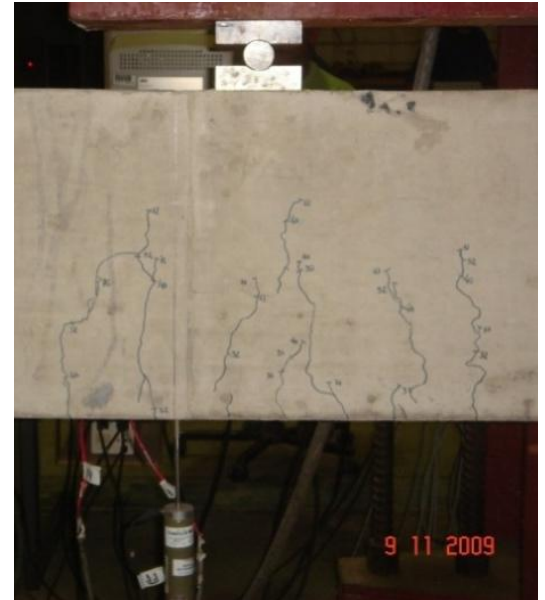

b) detalhe das fissuras do grupo B

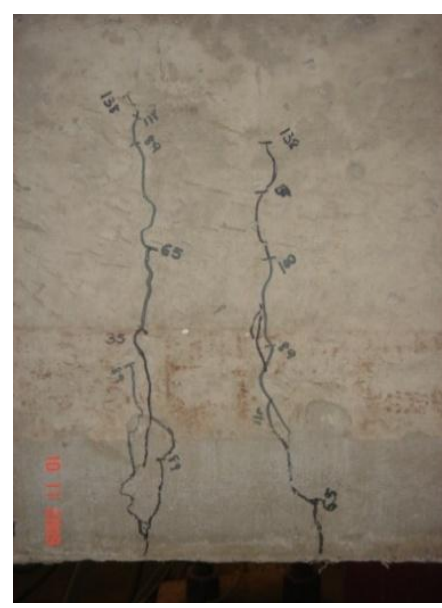

d) detalhe das fissuras de pequena dimensão do grupo $\mathrm{C}$

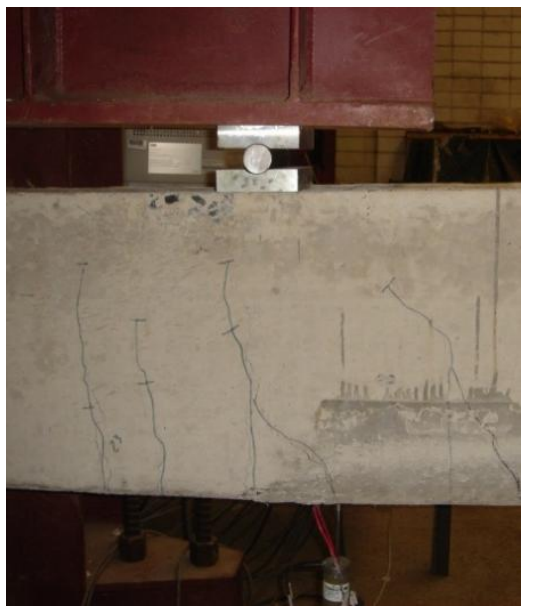

f) detalhe das fissuras do grupo D

Figura 5.18 - Detalhe da fissuração nas vigas dos grupos B, C e D 


\subsubsection{Forças}

$\mathrm{Na}$ Tabela 5.9 são apresentadas as forças de fissuração e as respectivas forças máximas resistidas pelas vigas até o momento de interrupção do ensaio.

Tabela 5.9 - Forças resistidas pelas vigas

\begin{tabular}{|c|c|c|c|c|c|}
\hline \multirow[t]{2}{*}{ Grupo } & \multirow[t]{2}{*}{ Viga } & \multirow{2}{*}{ 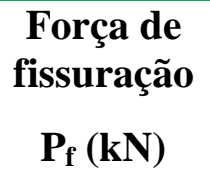 } & \multirow{2}{*}{$\begin{array}{c}\text { Força } \\
\text { máxima } \\
P_{u}(k N)\end{array}$} & \multicolumn{2}{|c|}{ Incremento (\%) } \\
\hline & & & & $\mathbf{P}_{\mathbf{f}}(\mathbf{k N})$ & $P_{u}(k N)$ \\
\hline \multirow{3}{*}{ A } & VA1 & 32,0 & 88,97 & - & - \\
\hline & VA2 & 27,0 & 79,49 & - & - \\
\hline & Média & 29,5 & 84,23 & - & - \\
\hline \multirow{2}{*}{ B } & VB1 & 18,0 & 99,15 & $-38,9$ & 17,7 \\
\hline & VB2 & 21,0 & 130,00 & $-28,8$ & 54,3 \\
\hline \multirow{2}{*}{$\mathrm{C}$} & VC1 & 35,0 & 155,94 & 18,6 & 85,1 \\
\hline & $\mathrm{VC} 2$ & 39,0 & 152,02 & 32,2 & 80,5 \\
\hline \multirow{2}{*}{$\mathrm{D}$} & VD1 & 23,0 & 140,50 & $-22,0$ & 66,8 \\
\hline & VD2 & 23,0 & 139,00 & $-22,0$ & 65,0 \\
\hline
\end{tabular}

Observa-se que o único grupo com aumento na carga de fissuração foi o que possuía o compósito cimentício em toda a extensão da viga. Como as demais vigas tiveram decréscimo na carga, pode-se concluir, assim como comentado na seção anterior, que o compósito na região mais predisposta à abertura de fissura (meio do vão), auxilia no controle de formação e propagação das mesmas.

A queda da carga de fissuração nos grupos B e D não era esperada, já que todas as vigas, inclusive as de referência, foram moldadas com o mesmo concreto e receberam o mesmo tipo de tratamento. Uma justificativa para o fato pode ser a formação de microfissuras ocasionadas durante a execução do entalhe para inserção dos laminados. No caso do grupo C, a presença das microfibras em toda extensão da viga pode ter auxiliado nesse processo.

Com relação às forças máximas resistidas, as vigas reforçadas apresentaram incremento de carga significativo em comparação com as vigas de referência, variando entre $54,3 \%$ e $85,1 \%$. A exceção ficou por conta da viga VB1, que proporcionou apenas $17,7 \%$, enquanto sua similar teve aumento de $54,3 \%$. O problema consistiu no tamanho inferior do 
entalhe, que possibilitou que parte do laminado ficasse fora da viga, diminuindo a quantidade de reforço. Por isso, a VB1 não apresenta resultados coerentes para ser comparada às demais vigas. Nesse caso, seus valores serão descartados e representados apenas como forma de complementação.

Realizando uma análise entre as vigas reforçadas, observa-se que a viga $\mathrm{VC} 1$ possui força máxima 11\% superior à VD1 (melhor resultado do grupo D) e 20\% superior à VB2 (melhor resultado do grupo B). Essas diferenças demonstram que a presença do compósito cimentício melhora a capacidade de carga do reforço, diminuindo a eficiência conforme diminui sua presença na viga.

De todos os valores apresentados, referindo-se tanto às cargas de fissuração quanto às cargas máximas, as melhores respostas foram obtidas pelo grupo $\mathrm{C}$, seguidos dos grupos $\mathrm{D}$ e B. Ou seja, o compósito cimentício, assim como no estudo com manta, proporciona um melhor aproveitamento do reforço, diminuindo a fissuração e aumentando a capacidade de carga.

Salienta-se que os valores obtidos em todas as vigas poderiam ser ainda maiores, se os ensaios não tivessem sido interrompidos antes da ruptura do reforço.

Esse fato dificultou a comparação entre os resultados. Além disso, seria imprudente compará-los sem um parâmetro fixo comum a todas as vigas. Portanto, propôs-se utilizar o limite de deformação limite do aço no estado limite último (10\%), para servir como referência e possibilitar a análise dos resultados obtidos através das diferentes formas de ancoragem do laminado.

Esse valor foi estabelecido porque, além dele, os elementos estruturais submetidos à ação de momento fletor podem apresentar fissuras com grandes aberturas, o que estruturalmente não é interessante.

Dessa maneira, as forças máximas atingidas foram as seguintes (Tabela 5.10): 
Tabela 5.10 - Forças resistidas pelas vigas até a deformação limite do aço (10\%)

\begin{tabular}{c|c|c|c}
\hline \multirow{2}{*}{ Grupo } & Viga & $\begin{array}{c}\text { Força } \\
\text { máxima } \\
\mathbf{P}_{\mathbf{u}}(\mathbf{k N})\end{array}$ & $\begin{array}{c}\text { Incremento } \\
\mathbf{( \% )}\end{array}$ \\
\hline \multirow{4}{*}{$\mathrm{A}$} & VA1 & 88,94 & - \\
\cline { 2 - 4 } & VA2 & 79,49 & - \\
\cline { 2 - 4 } & Média & $\mathbf{8 4 , 2 3}$ & - \\
\hline \multirow{2}{*}{ B } & VB1 & 99,15 & 17,7 \\
\cline { 2 - 4 } & VB2 & 126,50 & 50,2 \\
\hline \multirow{3}{*}{ C } & VC1 & 140,33 & 66,6 \\
\cline { 2 - 4 } & VC2 & 136,94 & 62,6 \\
\hline \multirow{2}{*}{ D } & VD1 & 123,00 & 46,1 \\
\cline { 2 - 4 } & VD2 & 117,15 & 39,5 \\
\hline
\end{tabular}

Analisando os resultados do grupo $\mathrm{C}$, que demonstrou melhor desempenho antes e após o valor limite de deformação do aço igual a 10\%, verifica-se que o incremento de reforço é mais significativo após o escoamento da armadura. O aumento da capacidade de carga passou de $66,6 \%$ para $85,1 \%$. O mesmo ocorreu com o grupo D, que passou de $46,1 \%$ para $66,8 \%$. Já o grupo B não apresentou incremento significativo, passando de 50,2 \% para $54,3 \%$.

Esses aumentos na capacidade de carga comprovam que o uso do compósito cimentício é uma boa alternativa para melhorar o aproveitamento do reforço.

\subsubsection{Deformações}

Nesta seção descrevem-se as deformações de maneira independe para cada material, valendo a condição de que os valores máximos foram correspondentes à deformação, limite do aço $(10 \%)$.

\subsubsection{Deformação no concreto comprimido}

A média das deformações obtida através dos dois extensômetros fixados na face comprimida da viga pode ser vista na Figura 5.19: 


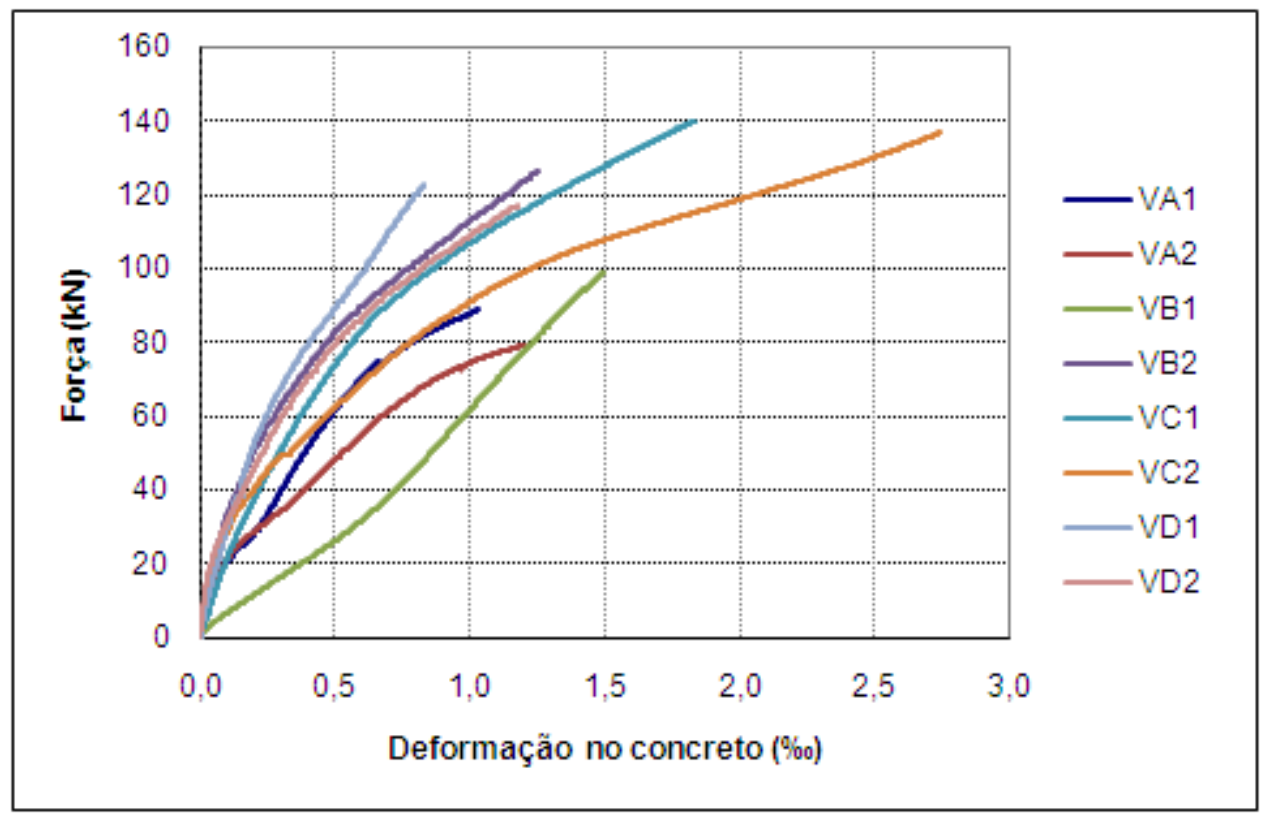

Figura 5.19 - Curvas força x deslocamento vertical de todas as vigas

Em todos os casos, a deformação do concreto foi inferior à máxima admitida para os domínios 3 e 4, que é igual a 3,5\%, conforme a ABNT NBR 6118 (2003). Isso demonstra que as vigas atingiram o Estado Limite Último convencional típico do domínio 2, coerentemente com a previsão inicial. Em nenhuma viga foi observada fissuração na região comprimida.

Com exceção da viga VB1, as demais vigas apresentaram comportamento semelhante e muito próximo da linearidade até o início da fissuração. Apenas para relembrar, a VB1 apresentou problema de confecção no reforço e pode ser desprezada.

Nota-se a diminuição da deformação nas vigas reforçadas em relação às vigas de referência para uma mesma carga. Nas vigas sem o compósito cimentício no meio do vão (grupos B e D), as deformações foram semelhantes entre si e menores. Já as vigas do grupo C, apresentaram deformações maiores, atingindo em média 2,30\%o no final do carregamento. Ou seja, as vigas que obtiveram as maiores deformações foram as que atingiram as maiores forças.

Esse comportamento é facilmente explicado através do equilíbrio de forças internas atuantes na seção transversal da viga. $\mathrm{O}$ aumento da solicitação à tração deve ser compensado com o aumento da solicitação à compressão. Por esse motivo é que Bonaldo, Barros e Lourenço (2006) sugerem o uso de concreto com fibras na face comprimida do concreto, como comentado no Capítulo 2. 


\subsubsection{Deformação no aço}

A Figura 5.20 apresenta as deformações nas barras de aço obtidas pelos extensômetros distribuídos em seus comprimentos. Os valores dos extensômetros 3 e 4 correspondem aos valores médios das duas barras.

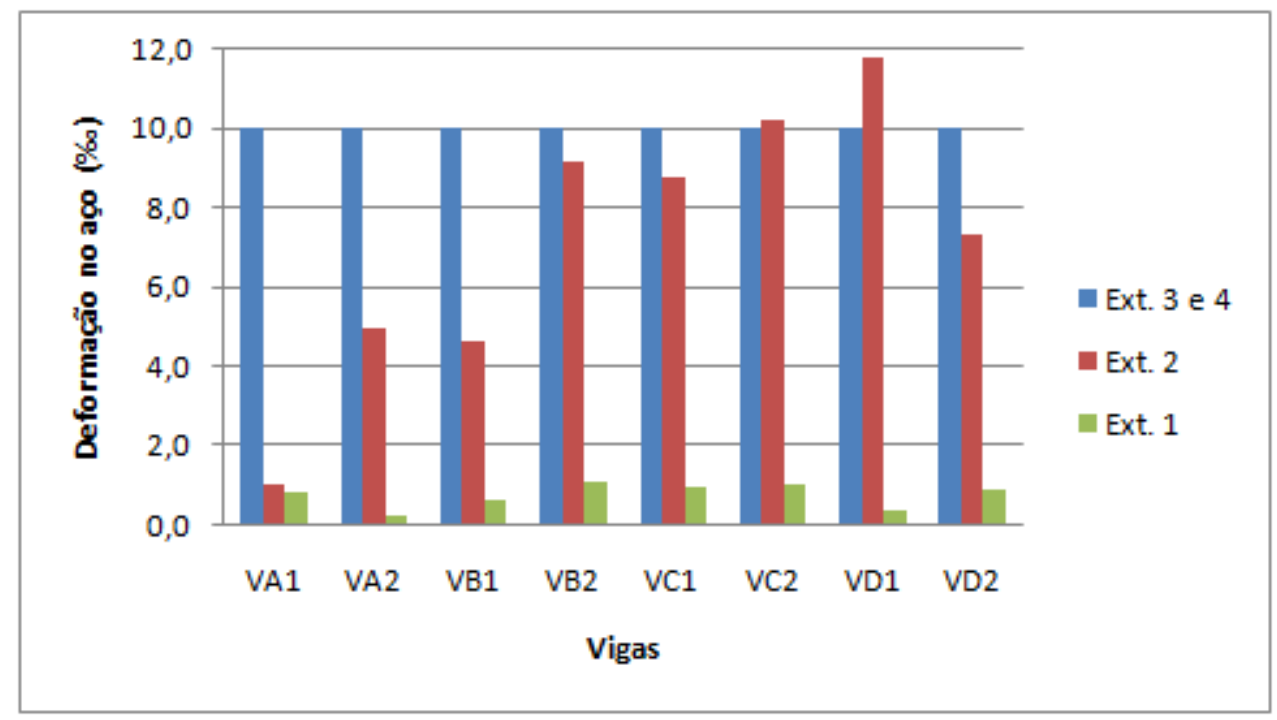

Figura 5.20 - Deformação no aço

Com exceção das vigas de referência (grupo A), todas as outras apresentaram melhor distribuição dos esforços, com maior aproveitamento do aço, inclusive a VB1 que teve problema na execução do reforço.

A Figura 5.21 apresenta um diagrama de momento para um carregamento hipotético:

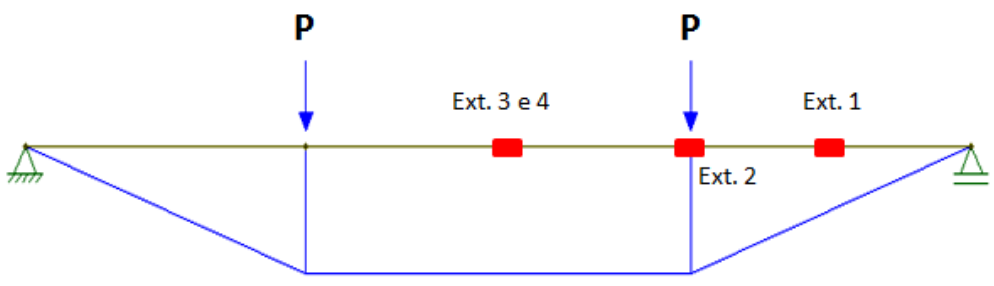

Figura 5.21 - Diagrama de momento para um carregamento hipotético

Como o extensômetro 1 fica muito próximo ao apoio e o momento nessa região é menor, é esperado que sua deformação seja reduzida. Analogamente, o extensômetro 2 
deveria ter uma deformação inferior à deformação obtida pelos extensômetros 3 e 4, assim como ocorre com as vigas de referência. Porém, essa diferença é reduzida sensivelmente nas vigas reforçadas.

Em média, o grupo $\mathrm{C}$ foi o que apresentou a melhor uniformidade de tensão ao longo do comprimento da armadura.

\subsubsection{Deformação no laminado de PRFC}

A Figura 5.22 apresenta as deformações médias registradas ao longo do comprimento do laminado:

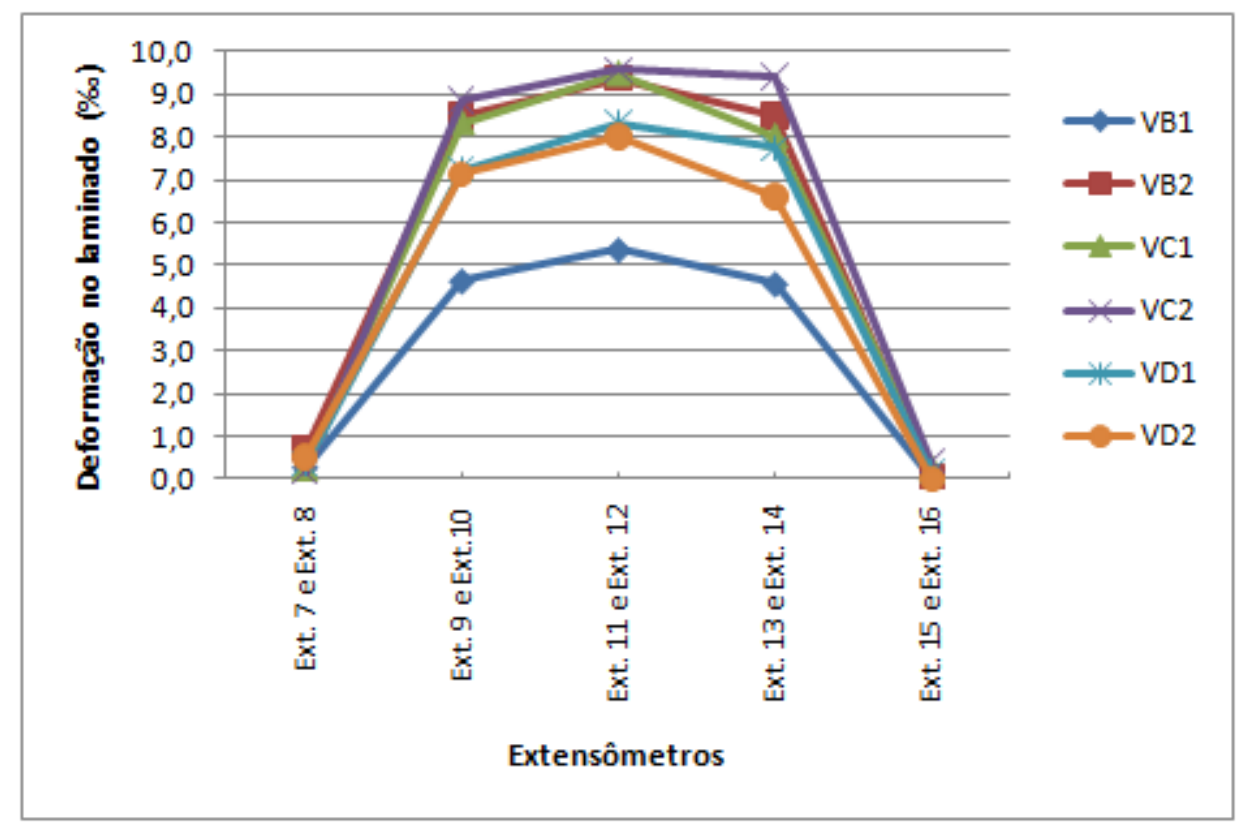

Figura 5.22 - Deformação no laminado

Em geral, as deformações foram simétricas em relação ao plano transversal da viga, como era esperado.

A Tabela 5.11 apresenta as máximas deformações obtidas nos laminados: 


\begin{tabular}{c|c|c} 
Tabela 5.11 - Deformações máximas nos laminados \\
\hline \multirow{2}{*}{ Grupo } & Viga & $\begin{array}{c}\text { Deformação } \\
\text { no laminado } \\
\mathbf{( \% )}\end{array}$ \\
\hline \multirow{2}{*}{ B } & VB1 & 5,36 \\
\cline { 2 - 3 } & VB2 & 9,38 \\
\hline \multirow{2}{*}{ C } & VC1 & 9,46 \\
\cline { 2 - 3 } & VC2 & 9,58 \\
\hline \multirow{2}{*}{ D } & VD1 & 8,33 \\
\cline { 2 - 3 } & VD2 & 8,02 \\
\hline
\end{tabular}

Com exceção da VB1, as demais vigas proporcionaram deformação no laminado variando entre 8,02 e 9,58\% . O melhor aproveitamento foi obtido pela viga $\mathrm{VC} 2$, atingindo $88 \%$ da deformação máxima do material, que é de 10,9\%.

É notável que a utilização do compósito cimentício em toda a extensão da viga (grupo C) favoreceu o aproveitamento quase que total do laminado. Por outro lado, seu uso apenas nos vãos de cisalhamento (grupo D) piorou o rendimento, inclusive comparado à viga sem inserção do compósito (grupo B). Ou seja, o compósito em si, não é o responsável pelo aumento de eficiência do laminado, mas os benefícios proporcionados por ele permitem o melhor aproveitamento do reforço, sobretudo em carregamentos mais avançados (Tabela 5.9). Essa conclusão já foi relatada por Cruz e Barros (2003) que realizaram ensaios de aderência com diferentes resistências de concreto e não observaram influência significativa na resposta final das vigas (Capítulo 2).

A Figura 5.23 apresenta graficamente a evolução da deformação adquirida através dos extensômetros fixados na região mais solicitada: 


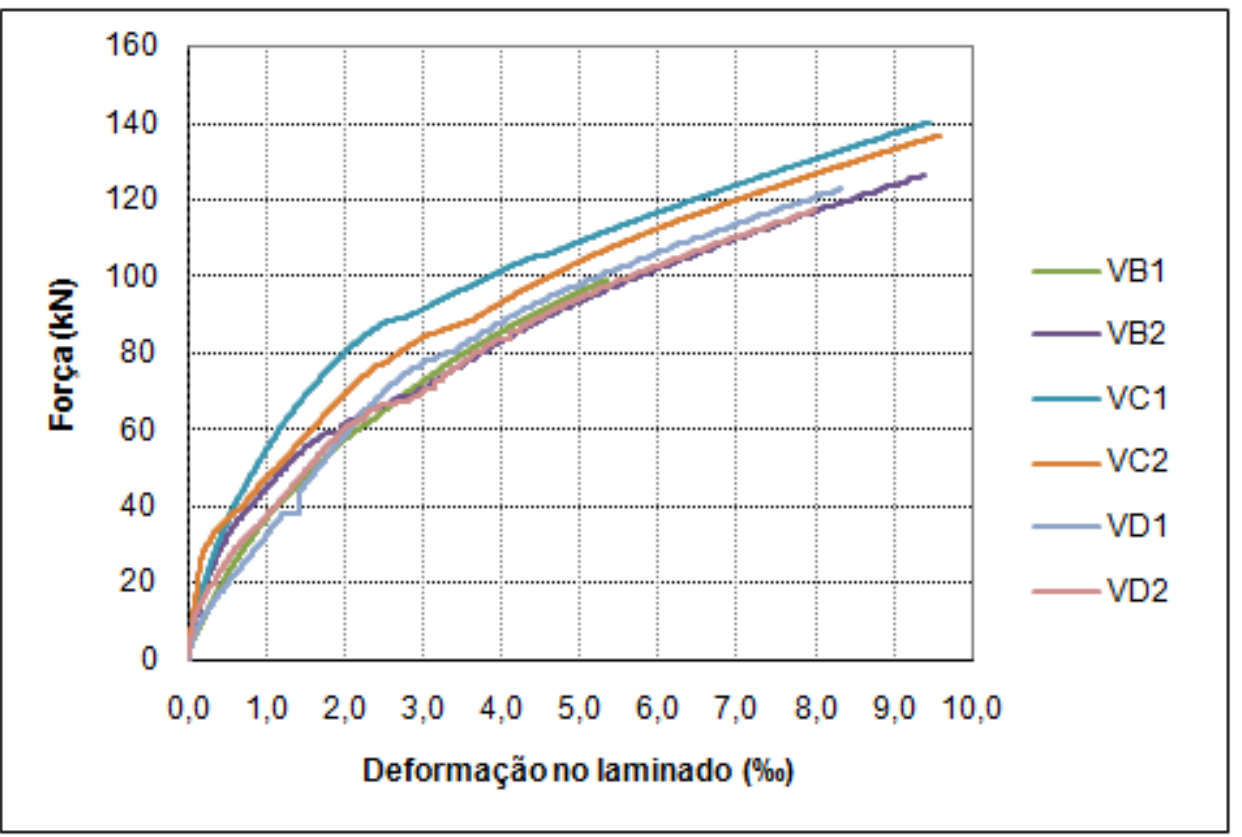

Figura 5.23 - Curva força $x$ deformação no laminado

O comportamento do laminado durante a aplicação da carga foi semelhante em todas as vigas. Só se observa a linearidade típica do material, depois de cargas superiores a $80 \mathrm{kN}$, possivelmente após a plastificação do aço. Anterior a isso, o trabalho conjunto do reforço com a armadura convencional, salienta uma não linearidade.

Através do gráfico da Figura 5.24, pode-se observar que não é a característica do laminado que muda ao trabalhar em conjunto com o aço, e sim, o modo como ocorre a distribuição dos esforços: 


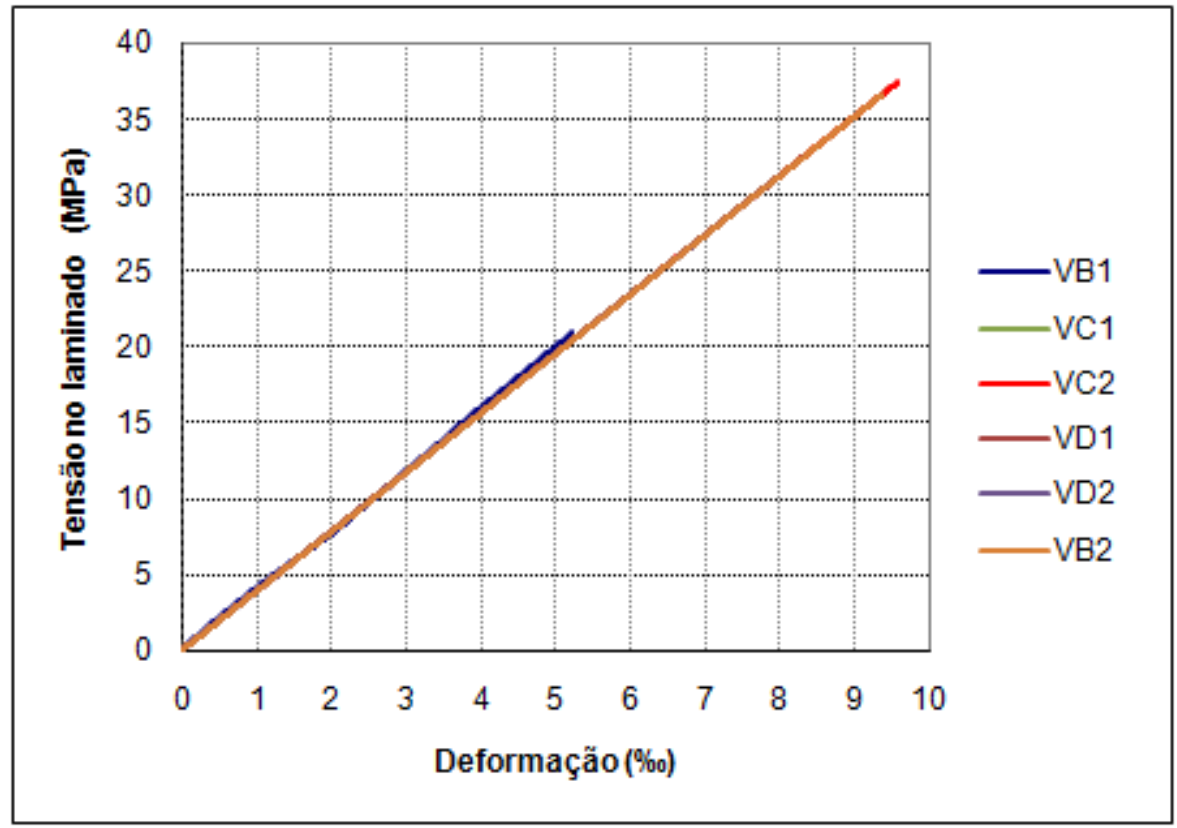

Figura 5.24 - Curva tensão x deformação no laminado

Esse gráfico foi construído com os valores das tensões solicitantes no laminado. Daí observa-se que o comportamento do material não é abalado pela ação conjunta com outro material.

Por essa diferença de comportamento entre os materiais é que se espera uma norma específica para dimensionamento de estruturas de concreto armado reforçada com PRFC inseridos no cobrimento de concreto.

\subsubsection{Compatibilização entre as deformações}

Para analisar o que ocorre simultaneamente com o concreto, o aço e o laminado, foi elaborada a Figura 5.25: 


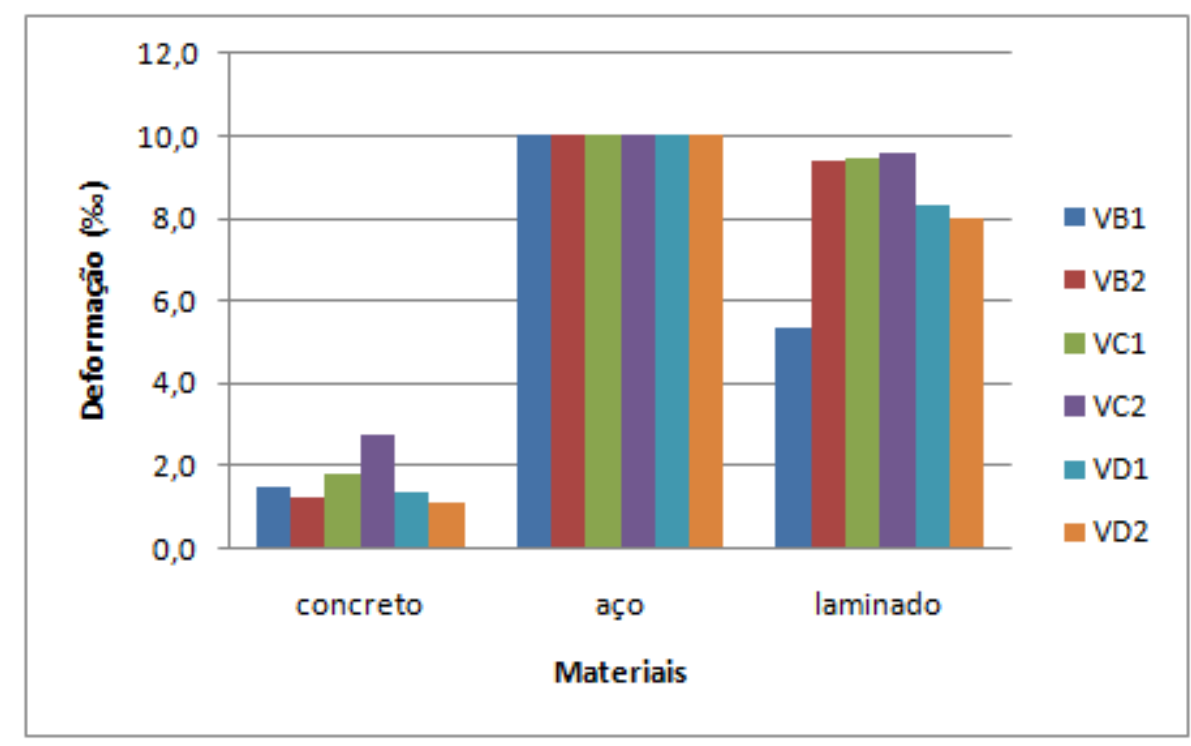

Figura 5.25 - Compatibilização entre as deformações

Excluindo a VB1 da análise, devido aos seus baixos resultados, observa-se que sua similar, a VB2, apresentou resultado muito próximo ao maior valor obtido para deformação no laminado, atingido pela VC2. Por outro lado, a deformação no concreto foi uma das mais baixas, possibilitando incrementar mais o reforço, sem dano ao concreto comprimido.

Com valor de deformação no concreto similar ao da VB2, aparecem as vigas do grupo D. Porém, o aproveitamento do laminado é o menor comparado aos outros grupos, gerando uma solução anti-econômica.

Por fim, existe o grupo C, que apresenta o melhor desempenho do laminado, mas também a maior deformação no concreto. Como explicado anteriormente, esse fato é justificado pela maior carga atuante na viga.

O curioso é que mesmo com a deformação do aço atingindo $10 \%$, ou seja, em seu patamar de escoamento, a deformação do laminado possui valor inferior. Este comportamento não respeita a hipótese de distribuição uniforme das deformações ao longo da seção transversal da viga. Por outro lado, proporciona o aumento de rigidez das vigas reforçadas. $\mathrm{O}$ mesmo ocorreu no trabalho de Castro (2005).

\subsubsection{Deslocamento vertical}

A Figura 5.26 apresenta o comportamento do deslocamento vertical proporcionado pelo aumento de carga: 


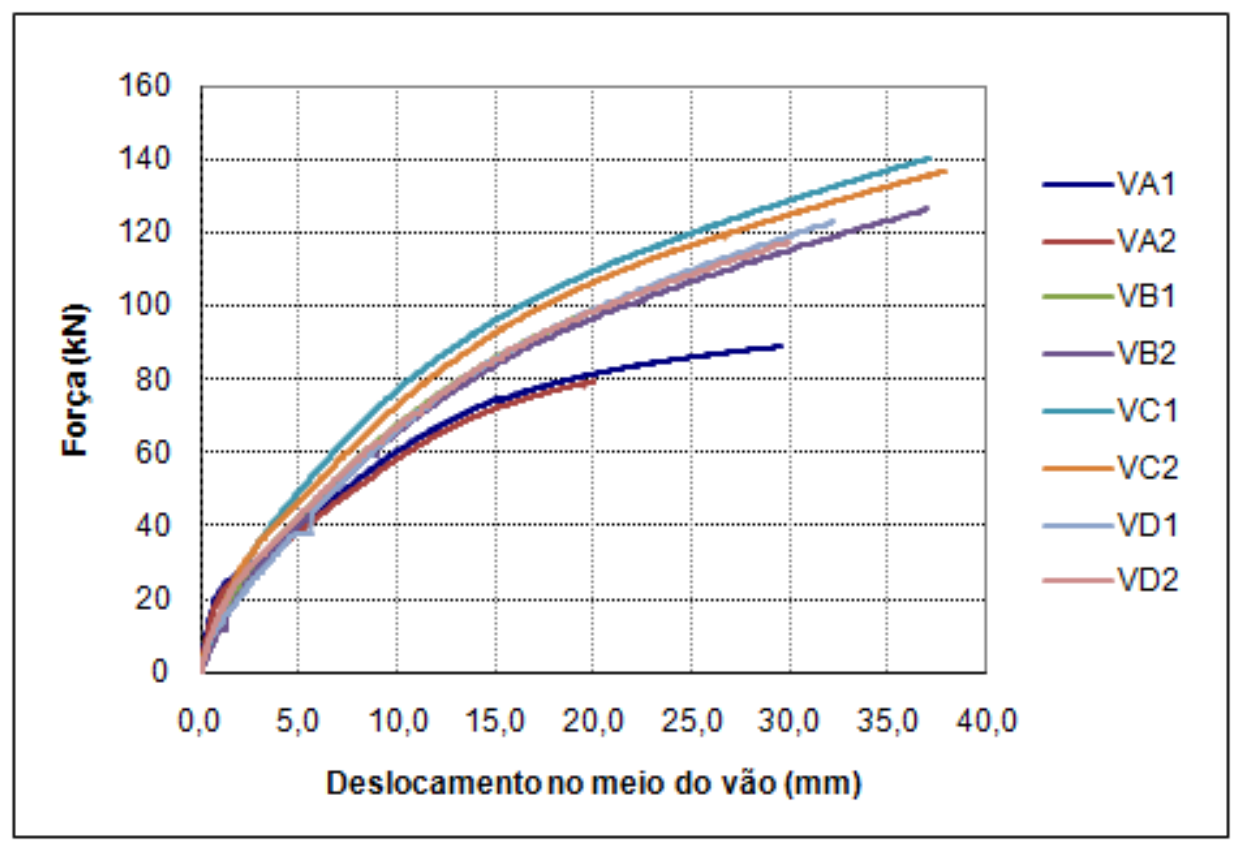

Figura 5.26 - Curvas força $x$ deslocamento vertical das vigas

Nota-se que até o início da fissuração, os deslocamentos não apresentam variação significativa. Em seguida ocorre a distinção de comportamentos, com as vigas reforçadas tornando-se mais rígidas que as de referência, sobretudo aquelas pertencentes ao grupo C. As vigas dos grupos B e D apresentam praticamente os mesmos deslocamentos entre si, comprovando que o compósito cimentício apenas nos vãos de cisalhamento não altera a rigidez das vigas.

Para entender melhor o que ocorre com a ductilidade das vigas, a Figura 5.27 apresenta os deslocamentos verticais ocorridos para dois valores fixos de carga, além dos deslocamentos máximos registrados. A primeira carga corresponde à média das forças máximas atingidas pelas vigas de referência, e igual a $84 \mathrm{kN}$. A segunda corresponde à carga máxima atingida pela VD2 que foi $117 \mathrm{kN}$. 


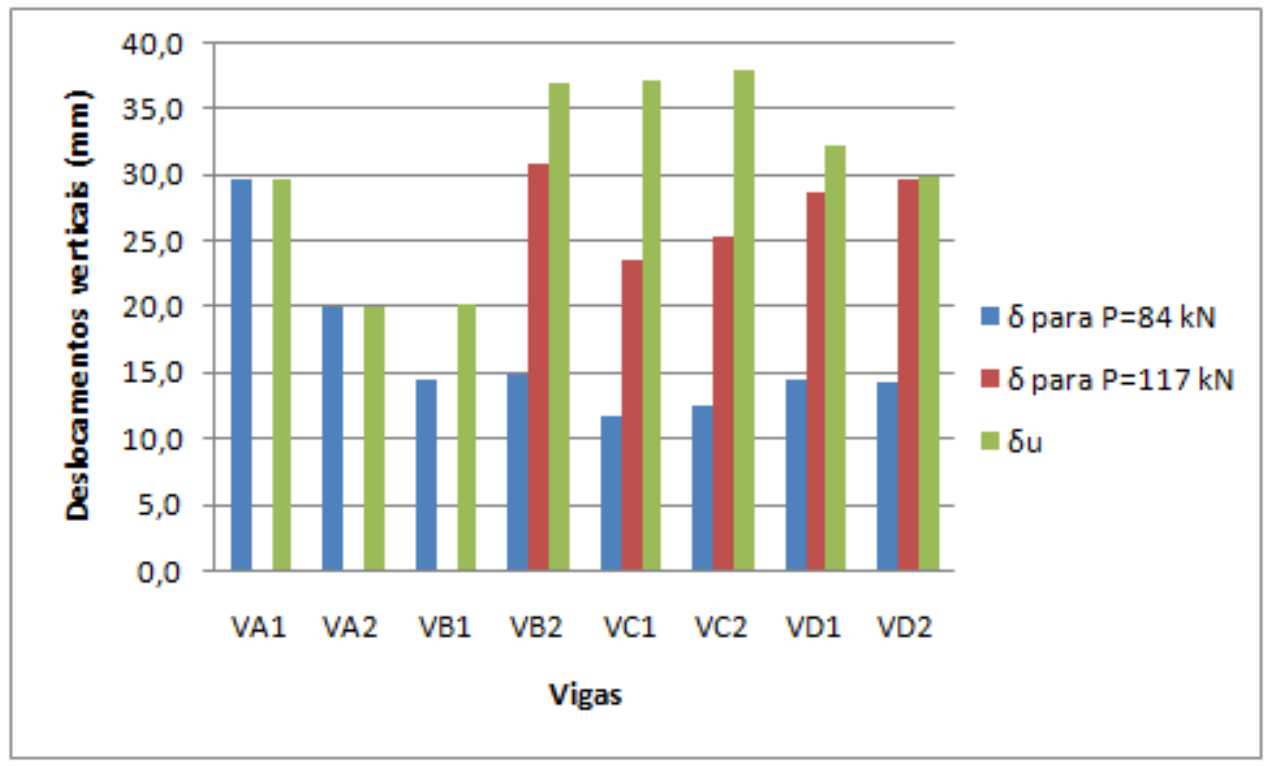

Figura 5.27 - Deslocamento das vigas para cargas pré-determinadas

Para a carga de $84 \mathrm{kN}$, enquanto as vigas de referência atingiam 29,54 mm na VA1 e 20,02 mm na VA2, as vigas reforçadas atingiram o valor máximo de 14,95 mm na VB2 e mínimo de 11,68 mm na VC1. A redução do deslocamento variou de $34 \%$ a $153 \%$. Ou seja, independente da forma de ancoragem dos laminados, as vigas reforçadas são mais rígidas que as vigas sem reforço.

Aumentando a carga para $117 \mathrm{kN}$, portanto excluindo as vigas de referência e realizando a análise entre as vigas reforçadas, nota-se pouca diferença entre a VB2 $(30,81$ $\mathrm{mm})$, a VD1 $(28,66 \mathrm{~mm})$ e a VD2 $(29,56 \mathrm{~mm})$. Isso demonstra como comentado anteriormente, que o uso do compósito cimentício apenas nos vãos de cisalhamento não altera a rigidez das vigas. Por outro lado, seu uso em toda a extensão da viga, diminui o deslocamento para o valor máximo de $25,29 \mathrm{~mm}$ registrado na viga VC2, aumentando a rigidez em pelo menos $22 \%$.

Analisando o decorrer dos resultados, partindo da carga igual a $117 \mathrm{kN}$ até a carga máxima registrada em cada ensaio (até o limite de deformação do aço), nota-se um deslocamento praticamente constante entre as vigas VB1 $(37,03 \mathrm{~mm}), \mathrm{VC} 1(37,12 \mathrm{~mm}) \mathrm{e}$ VC2 $(37,95 \mathrm{~mm})$. Porém, para cargas máximas iguais a $126,50 \mathrm{kN}, 140,33 \mathrm{kN}$ e 136,94 kN, respectivamente. Ou seja, para um menor incremento de carga, a VB1 obteve deslocamento similar às vigas do grupo $\mathrm{C}$, fazendo dela um elemento mais dúctil. 
Com isso, pode-se afirmar que o objetivo da inserção de fibras e microfibras de aço em toda a extensão da viga (grupo C) foi cumprido, uma vez que apresentou as menores aberturas de fissuras traduzidas pelo aumento de rigidez.

Os deslocamentos foram os menores registrados em comparação com as outras vigas para a mesma carga. Ao mesmo tempo, como a capacidade de carga foi maior, o deslocamento máximo foi recíproco, porém sem qualquer sinal de destacamento do laminado. Em outras palavras, mesmo sendo mais rígidas, as vigas do grupo $\mathrm{C}$ conseguiram se deformar sem apresentar transtorno ao reforço.

A Figura 5.28 representa o perfil das vigas com os deslocamentos verticais máximos obtidos até a carga correspondente a deformação admissível do aço:

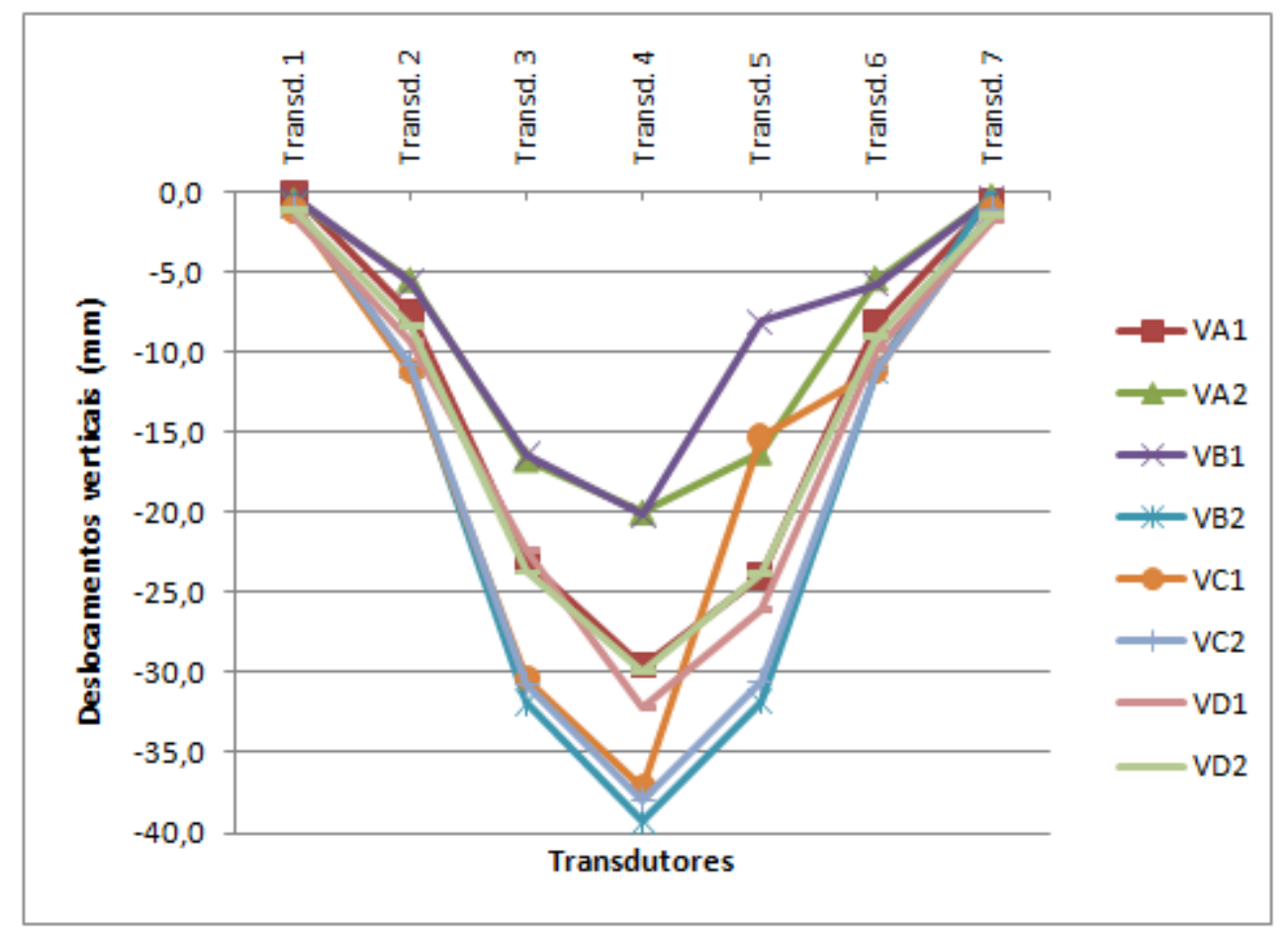

Figura 5.28 - Deslocamentos verticais

Fazendo uma verificação de deformações excessivas da estrutura no estado limite de serviço de acordo com a ABNT NBR 6118 (2003), tem-se o limite de deslocamento igual a l/250 para o efeito de aceitabilidade sensorial através da limitação visual. Como o vão é de $320 \mathrm{~cm}$, o deslocamento limite é igual a 12,8 mm. Logo (Tabela 5.12): 


\begin{tabular}{|c|c|c|c|}
\hline Grupo & Viga & $\begin{array}{c}\text { Força }(\mathrm{kN}) \text { para } \\
\delta=12,8 \mathrm{~mm}\end{array}$ & Incremento (\%) \\
\hline \multirow{3}{*}{ A } & VA1 & 69,05 & - \\
\hline & VA2 & 66,80 & - \\
\hline & Média & 67,93 & - \\
\hline \multirow{2}{*}{ B } & VB1 & 78,30 & 15,3 \\
\hline & VB2 & 76,50 & 12,6 \\
\hline \multirow{2}{*}{ C } & VC1 & 88,50 & 30,3 \\
\hline & VC2 & 84,77 & 24,8 \\
\hline \multirow{2}{*}{ D } & VD1 & 78,00 & 14,8 \\
\hline & VD2 & 78,00 & 14,8 \\
\hline
\end{tabular}

Mais uma vez o desempenho dos grupos B e D foi semelhante, inviabilizando o uso do compósito cimentício nos vãos de cisalhamento. Mesmo assim, o aumento de carga chegou a quase $15 \%$ em comparação às vigas de referência. Enquanto isso, o grupo $\mathrm{C}$ apresentou até $30,3 \%$ de aumento de carga para o deslocamento máximo no estado limite de serviço.

Pode-se dizer que, de forma resumida, tanto para o estado limite último quanto para o estado limite de serviço, as vigas com melhores retornos ao objetivo proposto, foram as pertencentes ao grupo C.

\subsubsection{Deslizamento do laminado}

O deslizamento do laminado provocado pela deformação da viga foi praticamente imperceptível e uniforme entre os três diferentes tipos de ancoragem.

A Figura 5.29 apresenta a curva média cisalhamento no concreto $x$ deslocamento vertical, primeiramente com os valores de cisalhamento obtidos pelos extensômetros no meio do vão (Figura 5.29a) e em seguida, pelos extensômetros mais próximos ao apoio (Figura $5.29 b)$. 


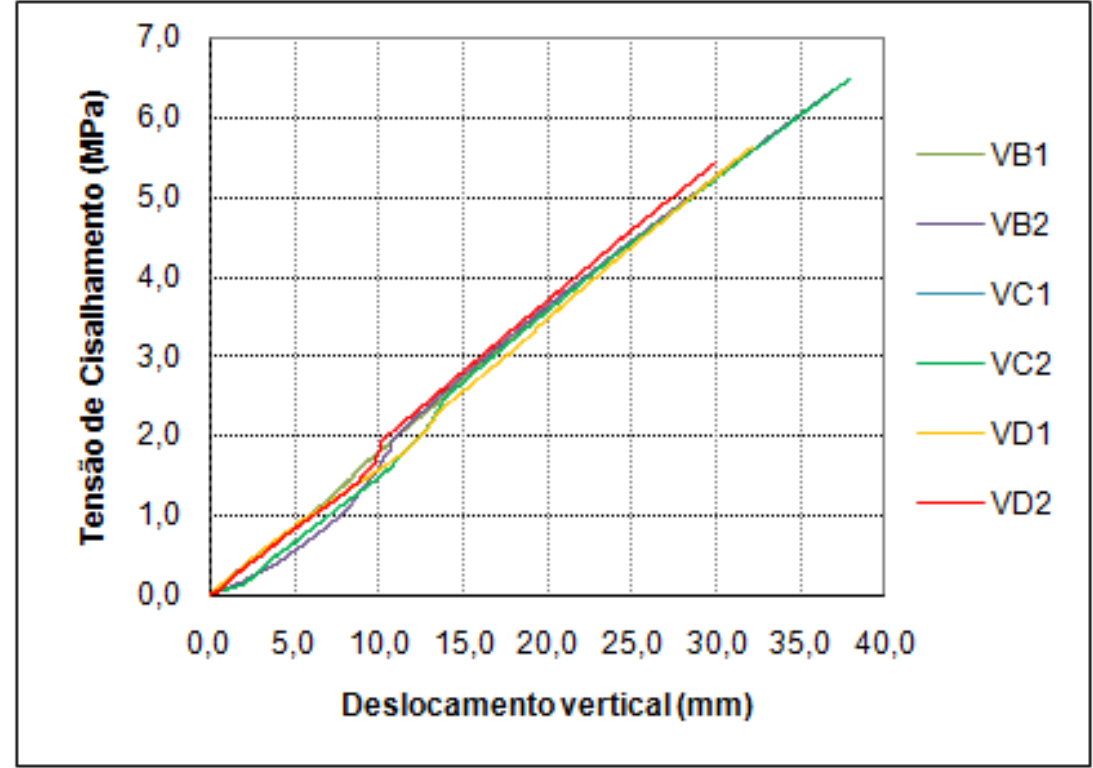

a) cisalhamento no concreto no meio do vão (extensômetros 11 e 12)

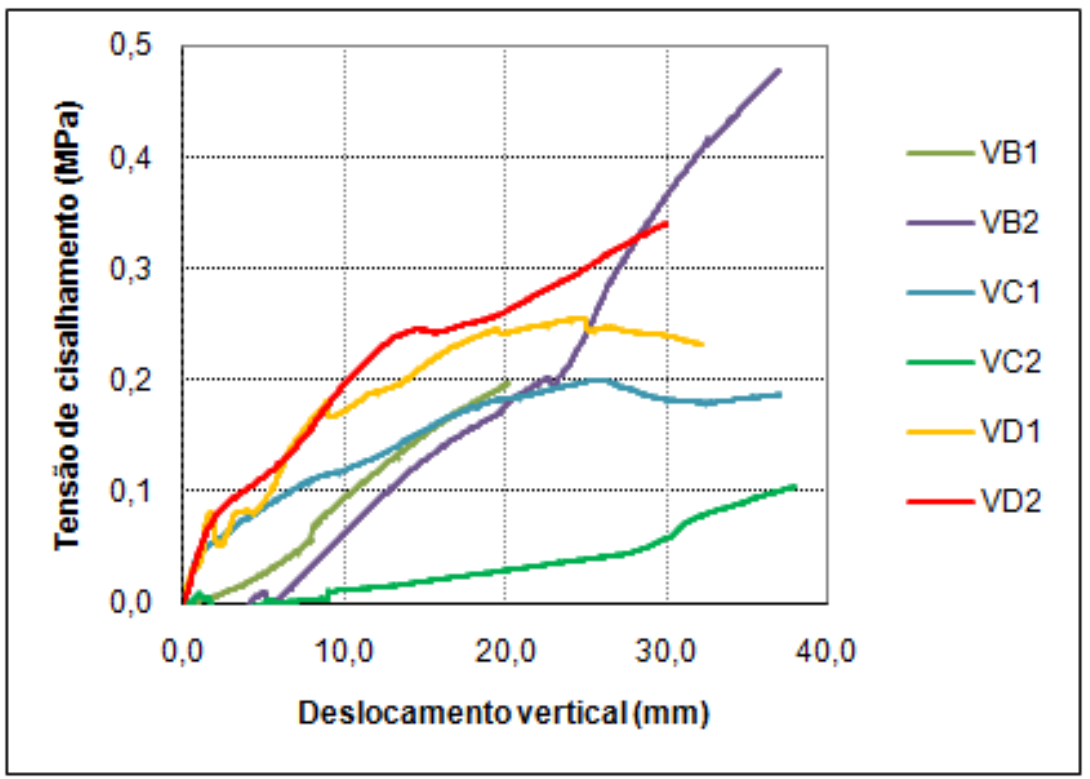

b) cisalhamento no concreto próximo ao apoio (extensômetros 7 e 8 )

Figura 5.29 - Curvas tensão de cisalhamento x deslocamento vertical

No meio do vão, notam-se tensões cisalhantes maiores que as que ocorrem no final da zona de ancoragem. Como a tensão de tração no laminado é máxima nessa região, o comportamento está dentro do esperado.

No início das curvas, percebe-se uma não-linearidade do cisalhamento, que coincide com o período de forças não-lineares no laminado. Mesmo assim, o comportamento das vigas é bastante próximo. Mas por volta de $2 \mathrm{MPa}$, o comportamento da tensão cisalhante no concreto passa a ter caráter linear, também com pouca diferença entre as vigas. 
A diferença foi mais significativa no final da zona de ancoragem, onde as vigas com o compósito nos vãos de cisalhamento proporcionou maior rigidez ao sistema.

Na Figura 5.30 aparecem as curvas tensão de cisalhamento $x$ deslocamento horizontal, novamente no meio e no final da zona de ancoragem.

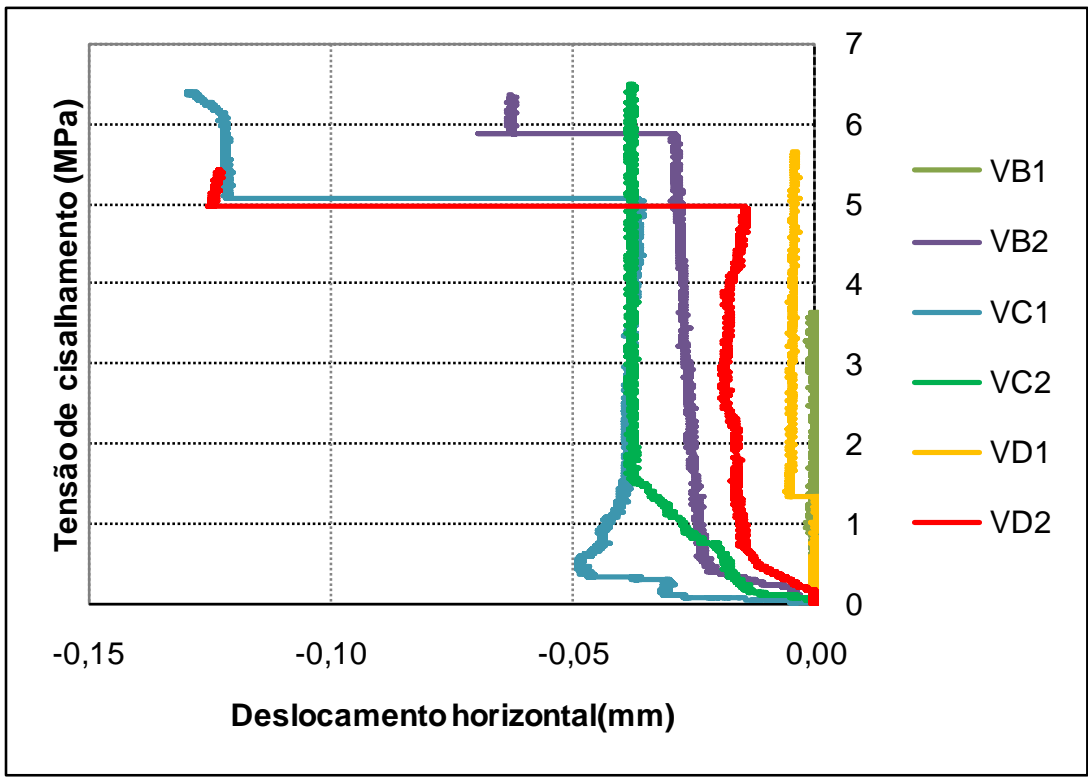

a) cisalhamento no concreto no meio do vão (extensômetros 11 e 12)

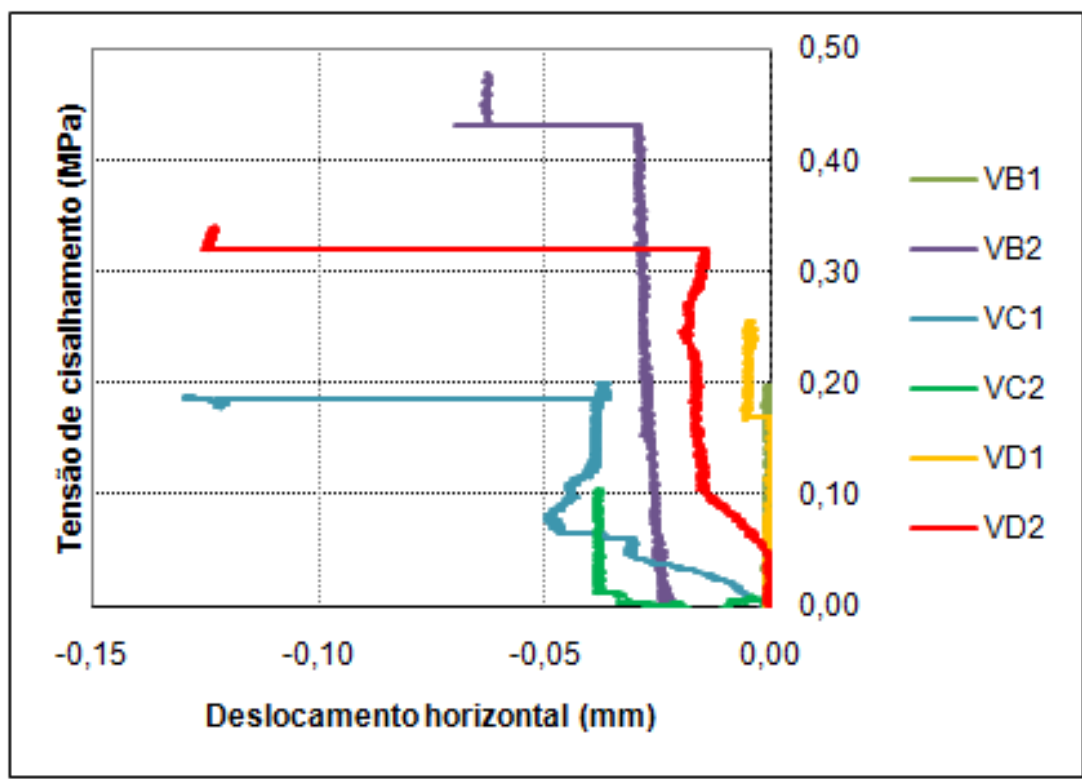

b) cisalhamento no concreto próximo ao apoio (extensômetros 7 e 8)

Figura 5.30 - Curvas tensão de cisalhamento x deslocamento horizontal

Em todos os casos, mesmo para os carregamentos mais avançados, os deslizamentos dos laminados foram quase desprezíveis, alcançando no máximo $0,13 \mathrm{~mm}$. No momento da 
possível plastificação do aço, com aproximadamente $2 \mathrm{MPa}$, não houve sinal de deslizamento ou acomodação dos laminados.

Percebe-se que o deslizamento apresentado apenas permitiu uma acomodação do laminado à curvatura da viga, para possibilitar maior capacidade de carga sem rompimento.

Surpreendentemente, as vigas que possuíam o compósito no final da zona de ancoragem, em especial as vigas VC1 e VD2, foram as que tiveram os maiores deslocamentos horizontais dos laminados. Isso aponta para a boa aderência proporcionada pela resina, sem benefício evidente trazido pelo compósito cimentício no final da região de ancoragem.

\subsection{Comparação com outros trabalhos}

Nessa seção, comparam-se os resultados obtidos nesse trabalho com vigas reforçadas por outros autores para verificar a eficiência da nova técnica proposta.

Serão apresentados três autores que reforçaram suas vigas de maneiras distintas:

- Ferrari (2007): reforço à flexão de viga de seção retangular com manta de PRFC;

- Castro (2005): reforço à flexão de viga de seção "T" com vários tipos de compósitos e com barras de aço;

- Fortes (2004): reforço à flexão de viga de seção retangular com laminado e manta.

\subsubsection{Apresentação}

Ferrari (2007)

Ferrari (2007) estudou seis vigas divididas em três séries. A Tabela 5.13 apresenta todas as características:

Tabela 5.13 - Características das vigas principais (Adaptado de FERRARI, 2007, p.212)

\begin{tabular}{c|c|c}
\hline Grupo & Vigas & Tipo de reforço \\
\hline \multirow{2}{*}{ A } & V1A & Viga de referência, sem reforço \\
\hline \multirow{2}{*}{ B } & V1B & $\begin{array}{c}\text { Viga em que o banzo tracionado foi demolido e reconstituído } \\
\text { parcialmente com o compósito cimentício. Após a cura do } \\
\text { compósito a viga foi reforçada com três camadas de manta de }\end{array}$ \\
\cline { 2 - 3 } & V2B &
\end{tabular}




\begin{tabular}{c|c|c}
\hline \multirow{2}{*}{} & V3B & fibra de carbono \\
\cline { 2 - 3 } & V1C & Viga reforçada com três camadas de manta de fibra de carbono \\
\cline { 2 - 3 } & V2C & $\begin{array}{c}\text { Viga em que o banzo tracionado foi demolido e reconstituído } \\
\text { integralmente com o compósito cimentício. Após a cura do } \\
\text { compósito a viga foi reforçada com três camadas de manta de } \\
\text { fibra de carbono }\end{array}$ \\
\hline
\end{tabular}

As vigas do grupo B apresentaram problema de aderência da resina e por isso foi proposto o grupo C. É esse novo grupo que servirá de referência para comparação entre os dois trabalhos.

A seção transversal, as armaduras utilizadas e as dimensões da reconstituição da viga com compósito cimentício são idênticas às utilizadas nesse trabalho, facilitando a comparação entre os resultados. A diferença fica por conta do novo compósito cimentício e do sistema de reforço, que passou de aderência externa da manta para aderência interna do laminado.

A resistência à compressão do concreto utilizado foi de 38,68 $\mathrm{MPa}$ e a resistência à tração de 3,23 MPa. O módulo de elasticidade foi de 29,38 MPa.

A resistência à tração do aço foi de 540,94 $\mathrm{MPa}$ para o diâmetro de 6,3 mm e 547,99 MPa para o diâmetro de 12,5 mm. Os módulos de elasticidade foram de 176,32 GPa e 210,92 GPa respectivamente.

A resistência à tração da manta foi de $3169 \pm 129 \mathrm{MPa}$, a deformação última de 13,13 $\pm 0,5 \%$ e o módulo de elasticidade de $234 \pm 9 \mathrm{GPa}$.

\section{Castro (2005)}

Castro (2005) analisou dezenove vigas de seção “T” reforçadas à flexão, dividas entre as técnicas de compósitos inseridos em entalhes no cobrimento de concreto (CEC) e tecido de PRFC aderido externamente à superfície (CSC).

Para que as comparações fossem consistentes, a autora manteve o produto da área do reforço pelo módulo de elasticidade constante, dentro do possível. 
Embora todas as vigas possuíssem a mesma seção transversal, a taxa de armadura longitudinal variou de $2 \Phi 20(\rho=0,63 \%)$ para $5 \Phi 20(\rho=1,57 \%)$, dividindo-as entre as séries I e II, respectivamente. Cada série ainda foi dividida em seis grupos, como mostra a Tabela 5.14:

Tabela 5.14 - Características das vigas (Adaptado de CASTRO, 2005, p.105)

\begin{tabular}{|c|c|c|c|c|}
\hline \multirow[t]{2}{*}{ Grupos } & \multicolumn{2}{|c|}{ Vigas } & \multirow[t]{2}{*}{ Tipo de reforço } & \multirow[t]{2}{*}{ Técnica utilizada } \\
\hline & $\begin{array}{c}\text { Série I } \\
\rho=0,63 \%\end{array}$ & $\begin{array}{l}\text { Série II } \\
\rho=1,57 \%\end{array}$ & & \\
\hline \multirow{2}{*}{ A } & VA 2.1 & VA 5.1 & \multirow{2}{*}{ Viga de referência } & \multirow{2}{*}{-} \\
\hline & VA 2.2 & VA 5.2 & & \\
\hline \multirow{2}{*}{ B } & VB 2.1 & \multirow{2}{*}{ VB 5.1} & \multirow{2}{*}{$\begin{array}{l}3 \text { tiras de PRFC (2 } \\
\text { mm } \times 16 \mathrm{~mm})\end{array}$} & \multirow{2}{*}{$\begin{array}{l}\text { Coladas em entalhes no } \\
\text { concreto (CEC) }\end{array}$} \\
\hline & VB 2.2 & & & \\
\hline \multirow{2}{*}{$\mathrm{C}$} & VC 2.1 & \multirow{2}{*}{ VC 5.1} & \multirow{2}{*}{$\begin{array}{l}1 \text { barra de PRFC ( } \Phi \\
10 \mathrm{~mm})\end{array}$} & \multirow{2}{*}{$\begin{array}{l}\text { Coladas em entalhes no } \\
\text { concreto (CEC) }\end{array}$} \\
\hline & VC 2.2 & & & \\
\hline \multirow{2}{*}{$\mathrm{D}$} & VD 2.1 & \multirow{2}{*}{ VD 5.1} & \multirow{2}{*}{$\begin{array}{c}2 \text { barras de PRFC ( } \Phi \\
12,7 \mathrm{~mm})\end{array}$} & \multirow{2}{*}{$\begin{array}{l}\text { Coladas em entalhes no } \\
\text { concreto (CEC) }\end{array}$} \\
\hline & VD 2.2 & & & \\
\hline \multirow{2}{*}{$\mathrm{E}$} & VE 2.1 & \multirow{2}{*}{ VE 5.1} & \multirow{2}{*}{$\begin{array}{l}2 \text { camadas de tecido } \\
\text { de PRFC }(0,165 \mathrm{~mm} \\
\quad \text { x } 150 \mathrm{~mm})\end{array}$} & \multirow{2}{*}{$\begin{array}{c}\text { Coladas na superfície do } \\
\text { concreto (CSC) }\end{array}$} \\
\hline & VE 2.2 & & & \\
\hline \multirow{2}{*}{$\mathrm{F}$} & VF 2.1 & \multirow{2}{*}{ VF 5.1} & \multirow{2}{*}{$\begin{array}{c}1 \text { barra de aço }(\Phi 8 \\
\mathrm{mm})\end{array}$} & \multirow{2}{*}{$\begin{array}{l}\text { Coladas em entalhes no } \\
\text { concreto (CEC) }\end{array}$} \\
\hline & VF 2.2 & & & \\
\hline
\end{tabular}

A seção transversal da viga e o esquema de carregamento estático podem ser vistos na Figura 5.31: 


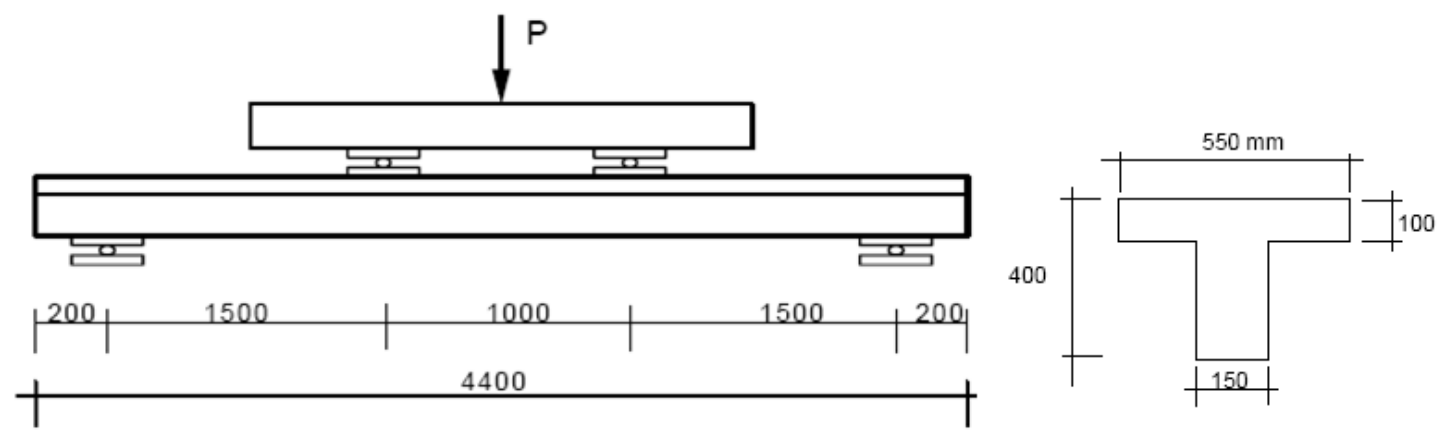

Figura 5.31 - Seção transversal das vigas e esquema estático de carregamento (Adaptado de CASTRO, 2005, p.106)

Dentre as vigas propostas, as que servirão de base para comparação serão a VB 2.1 e a VB 2.2, por serem reforçadas com a mesma técnica proposta nesse trabalho.

O detalhamento da viga por ser visto na Figura 5.32:

$\mathrm{N} 4-4 \phi 6.3 \mathrm{~mm}-\operatorname{comp} 4370 \mathrm{~mm} 1 \mathrm{c}$.

$\mathrm{N} 4-2 \phi 6.3 \mathrm{~mm}$ - comp $4370 \mathrm{~mm} 2 \mathrm{c}$.
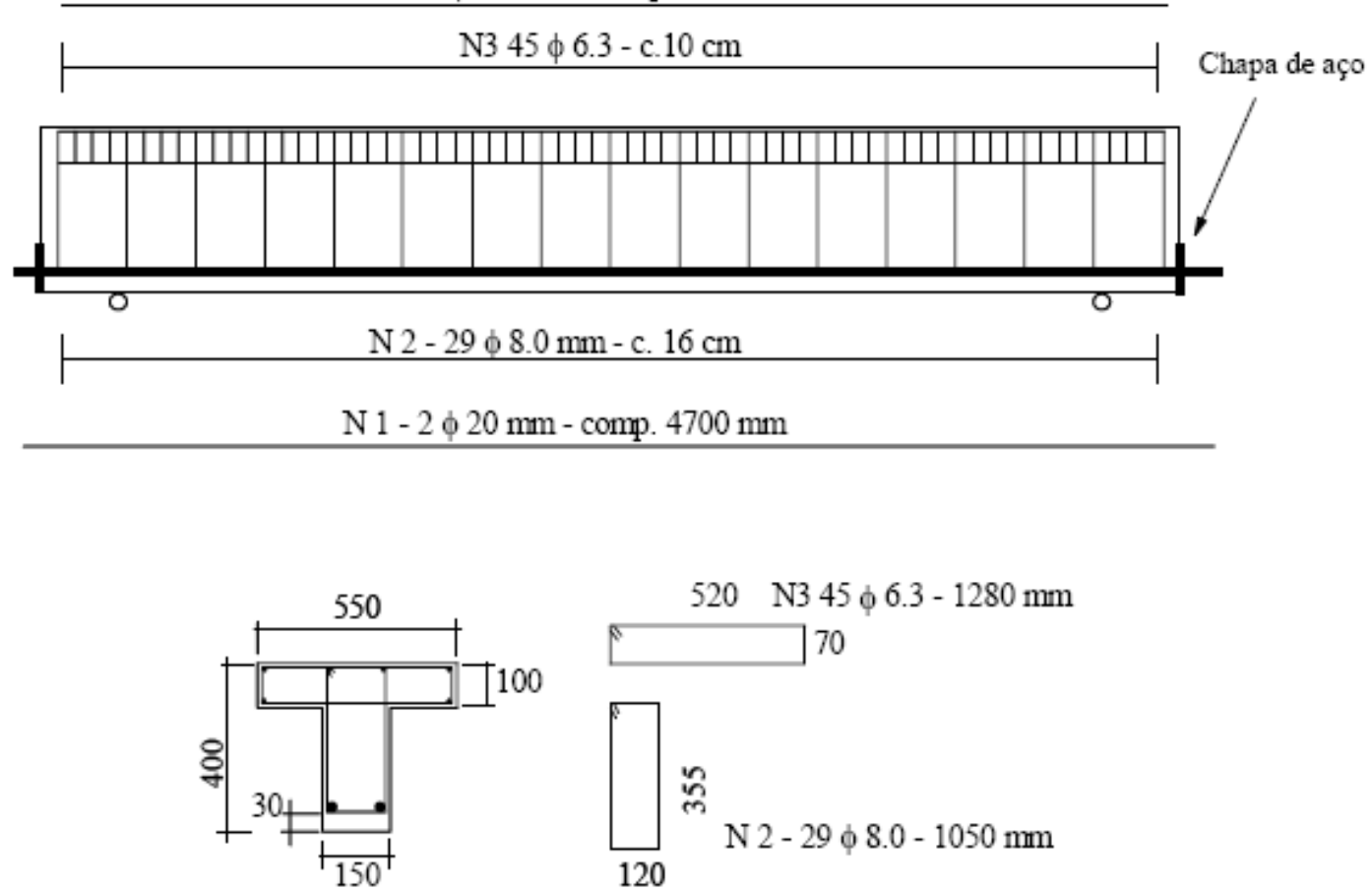

$520 \mathrm{~N} 345 \phi 6.3-1280 \mathrm{~mm}$

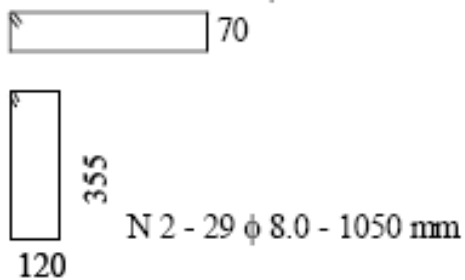

Figura 5.32 - Detalhamento das armaduras das vigas VB 2.1 e VB 2.2 (série I) (Adaptado de CASTRO, 2005, p.110) 
O detalhe do modo de inserção dos laminados e os valores obtidos na caracterização do laminado estão apresentados na Tabela 5.15:

Tabela 5.15 - Características de inserção e caracterização do laminado (Adaptado de CASTRO, 2005, p.115,133)

\begin{tabular}{l|l}
\hline Modo de inserção & \multicolumn{1}{c}{ Laminado } \\
\hline Resistência à tração última $=2707 \mathrm{MPa}$ \\
VB - 3 tiras de PRFC \\
$2 \times 16 \mathrm{~mm}$
\end{tabular}

*Dados fornecidos pelo fabricante

A resistência à compressão do concreto para a VB 2.1 foi de 49,5 MPa e a resistência à tração foi de 4,1 MPa, com módulo de elasticidade de $27 \mathrm{GPa}$. Para a VB 2.2 os valores foram 52,8 $\mathrm{MPa}, 3,3 \mathrm{MPa}$ e $28 \mathrm{GPa}$, respectivamente.

$\mathrm{O}$ aço apresentou resistência média de $552 \mathrm{MPa}$ para o diâmetro de 6,3 mm, $537 \mathrm{MPa}$ para o diâmetro de $8,0 \mathrm{~mm}$ e $552 \mathrm{MPa}$ para o diâmetro de 20,0 mm. Os módulos de elasticidade foram $216 \mathrm{GPa}, 221 \mathrm{GPa}$ e $223 \mathrm{GPa}$, respectivamente.

\section{Fortes (2004)}

Fortes (2004) analisou trinta e oito vigas de seção retangular reforçadas à flexão, dividas entre as técnicas de laminado inserido no cobrimento de concreto, e laminado e manta aderidos externamente.

O autor dividiu seus ensaios em três séries:

- S1: formada por quatro grupos, com dois exemplares cada, tendo cada grupo diferente taxa de armadura longitudinal e onde foi pesquisada a técnica de inserção de laminados no cobrimento de concreto; 
- S2: formada por três grupos, com oito exemplares cada, tendo cada grupo diferente taxa de armadura longitudinal. Nessa série o objetivo era comparar as técnicas de colagem de PRFC (interna e externa);

- S3: formada por três grupos, com dois exemplares cada, tendo cada grupo diferente taxa de armadura longitudinal e onde foi pesquisada a técnica de inserção de laminados no cobrimento de concreto. A diferença em relação à série S1 foi o aumento da largura da viga com o objetivo de diminuir o efeito cortante, e a presença de laminados de menor largura nas extremidades laterais da viga (onde existiam três reforços), para reduzir as tensões nas extremidades.

Para comparação, serão utilizadas as vigas pertencentes à série $\mathrm{S} 1$, devido à semelhança da técnica.

O reforço foi dimensionado por Fortes (2004) com o objetivo de duplicar a capacidade de carga da viga reforçada. Como houve variação na taxa de armadura longitudinal, também variou-se a quantidade de reforço. A Figura 5.33 apresenta a geometria das vigas, a disposição das armaduras e dos reforços, além do esquema estático do ensaio.

As resistências à compressão do concreto foram: 45,3 MPa para a série S1-1, 48,9 MPa para a série S1-2, 42,8 MPa para a série S1-3 e 46,4 MPa para a série S1-4.

O aço apresentou resistência de $750 \mathrm{MPa}$ para o diâmetro de 6,3 mm e $500 \mathrm{MPa}$ para o diâmetro de $8,0 \mathrm{~mm}$.

O laminado, com seção transversal igual a 9,59 $\pm 0,09 \mathrm{~mm}$ de largura e 1,45 $\pm 0,005$ mm de espessura, atingiu $2700 \mathrm{MPa}$ de resistência à tração, $158 \mathrm{GPa}$ de módulo de elasticidade e $17 \%$ de deformação última. 

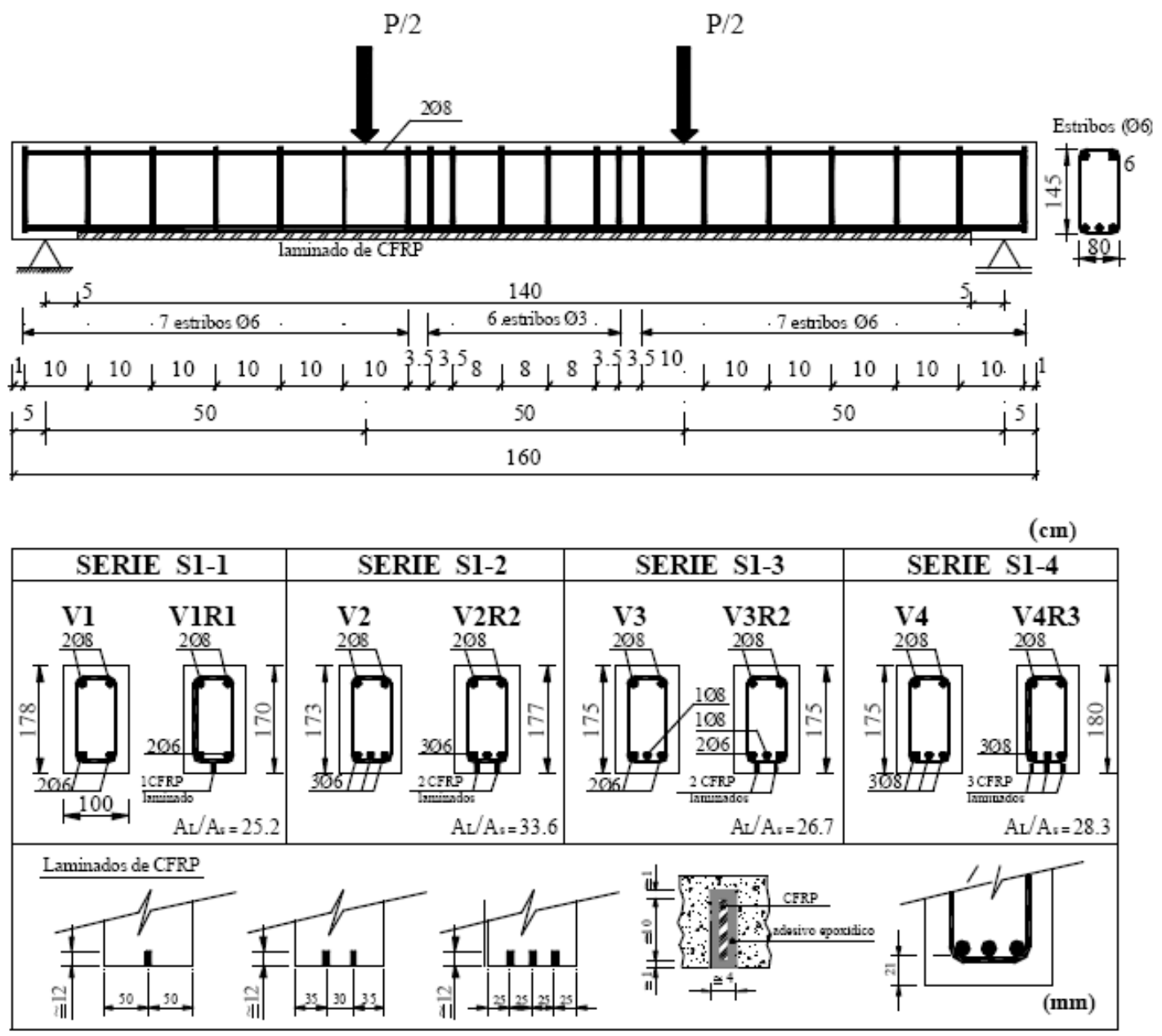

Figura 5.33 - Esquema de ensaio e detalhamento das vigas da série S1 (Adaptado de FORTES, 2004, p. 158)

\subsubsection{Comparação entre as técnicas NSM}

Como as vigas possuem geometria e taxas de reforço diferentes, fica praticamente impossível comparar as forças máximas atingidas em cada trabalho. Mas utilizando a equação 2.7 proposta por Fortes (2004), pode-se obter a taxa equivalente de armadura que servirá para análise dos resultados (Tabela 5.16).

Nessa seção, diferentemente do que aconteceu com as análises dos resultados, os valores apresentados do trabalho atual, são os máximos obtidos até o momento de interrupção do ensaio. $\mathrm{O}$ fato se justifica pela dificuldade em retirar graficamente os dados dos outros trabalhos no ponto específico e por observar que a partir da plastificação do aço até a ruptura, não há considerável aumento de carga nos outros trabalhos. 
Capítulo 5 - Vigas Principais

Tabela 5.16 - Forças e taxas das vigas comparadas

\begin{tabular}{|c|c|c|c|c|c|c|}
\hline Trabalho & Viga & $\begin{array}{c}\text { Força } \\
\text { máxima } \\
\mathbf{P}_{\mathbf{u}}(\mathbf{k N})\end{array}$ & $\begin{array}{c}\text { Incremento } \\
\text { de carga } \\
(\%)\end{array}$ & $\begin{array}{c}\text { Força de } \\
\text { fissuração } \\
\mathbf{P}_{\mathbf{f}}(\mathbf{k N})\end{array}$ & $\mathbf{P}_{\mathbf{f}} / \mathbf{P}_{\mathbf{u}}$ & $\begin{array}{c}\text { Taxa } \\
\text { equivalente }\end{array}$ \\
\hline \multirow{6}{*}{ Atual } & VR & 84,2 & - & 29,5 & 0,35 & - \\
\hline & VB2 & 130,0 & 54,3 & 21,0 & 0,16 & 0,52 \\
\hline & VC1 & 155,9 & 85,1 & 35,0 & 0,22 & 0,52 \\
\hline & $\mathrm{VC} 2$ & 152,0 & 80,5 & 39,0 & 0,26 & 0,52 \\
\hline & VD1 & 140,5 & 66,8 & 23,0 & 0,16 & 0,52 \\
\hline & VD2 & 139,0 & 65,0 & 23,0 & 0,16 & 0,52 \\
\hline \multirow{3}{*}{$\begin{array}{l}\text { Castro } \\
(2005)\end{array}$} & $\mathrm{VR}^{*}$ & 174,0 & - & 35 & 0,20 & - \\
\hline & VB 2.1 & 246,0 & 41,4 & 40,0 & 0,16 & 0,67 \\
\hline & VB 2.2 & 250,0 & 43,7 & 30,0 & 0,12 & 0,67 \\
\hline \multirow{8}{*}{$\begin{array}{l}\text { Fortes } \\
(2004)\end{array}$} & VR1 & 28,2 & - & 8,5 & 0,30 & - \\
\hline & V1R1 & 50,3 & 78,4 & 10,7 & 0,21 & 0,47 \\
\hline & VR2 & 41,0 & - & 8,1 & 0,20 & - \\
\hline & V2R3 & 78,5 & 91,5 & 12,3 & 0,15 & 0,70 \\
\hline & VR3 & 42,6 & - & 7,9 & 0,19 & - \\
\hline & V3R3 & 81,9 & 92,3 & 11,9 & 0,15 & 0,85 \\
\hline & VR4 & 48,5 & - & 8,1 & 0,17 & - \\
\hline & V4R4 & 94,9 & 95,7 & 14,1 & 0,15 & 1,19 \\
\hline
\end{tabular}

*Valores médios entre duas vigas

Em comparação com as vigas de referência, o atual trabalho apresentou aumento de carga variando entre 54\% obtida pela VB2 e 85\% obtida pela VC1. Castro (2005) obteve em média $43 \%$ de aumento e Fortes (2004) obteve incremento de $78 \%$ para a V1R1 e $96 \%$ para 
V4R4. Considerando que a VC1 possui $0,52 \%$ de taxa equivalente e a V4R4 possui $1,19 \%$, ou seja, um pouco mais que o dobro de reforço, é perceptível que o compósito cimentício possibilitou significativo aumento na capacidade de carga.

Quando o assunto é fissuração, não se observa um desvio considerável entre as vigas reforçadas. Independentemente da taxa equivalente, a proporção entre a carga de fissuração e a carga máxima varia entre $12 \%$ e $26 \%$. Deve-se lembrar que a identificação do início da fissuração é algo bastante subjetivo, dependendo da observação do pesquisador. Por isso, Fortes (2004) explica em seu trabalho, que diversos autores encontram valores no intervalo entre $10 \%$ e $35 \%$ da carga de ruptura, com elevada dispersão de valores.

Independentemente da carga, as fissuras podem ser fatais para o desempenho do reforço. Com os dois autores, houve o surgimento de uma fissura horizontal próxima à linha da armadura, que provocou o destacamento do laminado. Com exceção da V1R1 que teve o ensaio paralisado devido ao excessivo deslocamento vertical e da VB 2.2 onde houve rompimento do laminado, as demais vigas mantiveram a integridade do reforço com destacamento do concreto de cobrimento, deixando expostas as armaduras longitudinais. Em todos os casos, a resina permaneceu aderida ao laminado. Embora os ensaios desse trabalho tenham sido interrompidos antes da ruptura, nenhuma fissura horizontal foi identificada.

Para analisar o aproveitamento do reforço, a Tabela 5.17 apresenta os seguintes valores:

Tabela 5.17 - Aproveitamento do laminado das vigas reforçadas

\begin{tabular}{|c|c|c|c|c|}
\hline Trabalho & Viga & $\begin{array}{l}\text { Deformação } \\
\text { máxima (\%o) }\end{array}$ & $\begin{array}{c}\text { Deformação } \\
\text { obtida (\%o) }\end{array}$ & Aproveitamento \\
\hline \multirow{5}{*}{ Atual } & VB2 & \multirow{5}{*}{10,9} & 9,86 & $90,5 \%$ \\
\hline & VC1 & & 12,16 & $111,5 \%$ \\
\hline & $\mathrm{VC} 2$ & & 12,01 & $110 \%$ \\
\hline & VD1 & & 10,89 & $100 \%$ \\
\hline & VD2 & & 11,22 & $103 \%$ \\
\hline Castro & VB 2.1 & 19,5 & 11,5 & $59 \%$ \\
\hline
\end{tabular}




\begin{tabular}{|c|c|c|c|c|}
\hline (2005) & VB 2.2 & & 12,7 & $65 \%$ \\
\hline \multirow{4}{*}{$\begin{array}{l}\text { Fortes } \\
\text { (2004) }\end{array}$} & V1R1 & \multirow{4}{*}{17} & 15,5 & $91 \%$ \\
\hline & V2R2 & & 12,8 & $75 \%$ \\
\hline & V3R3 & & 12,8 & $75 \%$ \\
\hline & V4R4 & & 10,6 & $62 \%$ \\
\hline
\end{tabular}

Do atual trabalho, o menor aproveitamento $(90,5 \%)$ foi da viga sem aplicação do compósito cimentício. Da mesma forma, Fortes (2004) atingiu o mesmo valor de aproveitamento. A diferença foi que com o uso do compósito o rendimento foi ainda melhor. De qualquer maneira, seria imprudente dizer que o compósito aumenta o rendimento do reforço. Até porque, como foi visto anteriormente, na deformação máxima do aço, o grupo D apresenta desempenho inferior ao do grupo B.

O que se pode dizer é que, o compósito em si, não melhora de forma direta o aproveitamento do reforço. Porém ele dá subsídios para que a viga melhore suas características, aumentando a rigidez e diminuindo a fissuração, possibilitando o aumento da capacidade de carga.

Observa-se no trabalho de Fortes (2004) que quanto maior o número de laminados, menor o aproveitamento dos mesmos. Talvez por isso Castro (2005), com três laminados, apresentou em média, os piores resultados.

Partindo para a análise de rigidez, têm-se as seguintes condições (Tabela 5.18):

Tabela 5.18 - Deslocamento vertical das vigas comparadas

\begin{tabular}{c|c|c|c|c|c}
\hline Trabalho & Viga & $\begin{array}{c}\text { Deslocamento } \\
\text { vertical } \\
\text { máximo }(\mathbf{m m})\end{array}$ & $\begin{array}{c}\mathbf{l} / \boldsymbol{\delta} \\
\mathbf{( c m})\end{array}$ & $\begin{array}{c}\text { Incremento } \\
\text { de carga } \\
(\boldsymbol{\%})\end{array}$ & $\begin{array}{c}\text { Taxa } \\
\text { equivalente }\end{array}$ \\
\hline \multirow{4}{*}{ Atual } & VB2 & 39,25 & $1 / 81,5$ & 54,3 & 0,52 \\
\cline { 2 - 6 } & VC1 & 48,70 & $1 / 66$ & 85,1 & 0,52 \\
\cline { 2 - 6 } & VC2 & 49,03 & $1 / 65$ & 80,5 & 0,52 \\
\hline
\end{tabular}


Capítulo 5 - Vigas Principais

\begin{tabular}{c|c|c|c|c|c}
\hline & VD1 & 42,84 & $1 / 75$ & 66,8 & 0,52 \\
\cline { 2 - 6 } & VD2 & 43,46 & $1 / 74$ & 65,0 & 0,52 \\
\hline \multirow{2}{*}{$\begin{array}{c}\text { Castro } \\
(2005)\end{array}$} & VB 2.1 & 56,40 & $1 / 71$ & 41,4 & 0,67 \\
\cline { 2 - 6 } & VB 2.2 & 67,30 & $1 / 59$ & 43,7 & 0,67 \\
\hline \multirow{3}{*}{$\begin{array}{c}\text { Fortes } \\
(2004)\end{array}$} & V1R1 & 27,0 & $1 / 55,5$ & 78,4 & 0,47 \\
\cline { 2 - 6 } & V2R2 & 26,0 & $1 / 58$ & 91,5 & 0,70 \\
\cline { 2 - 6 } & V4R4 & 27,0 & $1 / 55,5$ & 92,3 & 0,85 \\
\cline { 2 - 6 } & V3R & $1 / 60$ & 95,7 & 1,19 \\
\hline
\end{tabular}

*Valores aproximados retirados dos gráficos do trabalho

Como os vão dos três trabalhos são diferentes, decidiu-se por utilizar o fator $1 / \delta$ para servir como parâmetro de comparação.

Do trabalho de Fortes (2004), observa-se que com o aumento da taxa equivalente de armadura, houve aumento da capacidade de carga das vigas, quase sem variação dos deslocamentos verticais. Logo, o aumento da taxa equivalente é diretamente proporcional ao aumento de rigidez das vigas.

No presente trabalho, não houve variação da taxa equivalente, porém houve aumento na capacidade de carga, com conseqüente deslocamento vertical das vigas. Mas para um valor fixo de carga, como visto na seção 5.1.4, as vigas do grupo $\mathrm{C}$ foram as mais rígidas. Isso remete a concluir que as fibras e microfibras de aço, além de funcionarem impedindo a abertura das fissuras, trabalham em conjunto com as armaduras longitudinais, aumentando a taxa equivalente de armadura. Ao mesmo passo, possibilitam o aumento da deformação das vigas nas cargas finais sem destacamento do reforço.

\subsubsection{Comparação com trabalho de Ferrari (2007)}

O trabalho de Ferrari (2007) foi bastante citado durante o decorrer da atual pesquisa por dar origem a essa proposta de estudo. Nesta seção, fazem-se algumas comparações entre 
os resultados dos dois trabalhos com o objetivo de analisar os benefícios proporcionados ao reforço com a inserção do compósito cimentício.

Inicialmente, como não se atingiu a ruptura do reforço no presente trabalho, houve uma dificuldade na comparação entre os resultados dos dois estudos. Por isso o critério utilizado foi o mesmo proposto anteriormente, onde os valores comparados correspondem à máxima deformação do aço no estado limite último (10\%o). No trabalho de Ferrari (2007) houve maior facilidade de obtenção dos dados.

De uma maneira geral, o comportamento das duas técnicas foi bastante semelhante. As vigas com compósito cimentício em toda a extensão proporcionaram aumento de carga, aumento de rigidez e diminuição da fissuração. Enquanto na colagem externa de manta o incremento de carga foi de $126 \%$, na técnica NSM o aumento foi de $66 \%$. O aumento de rigidez também foi maior na técnica de aderência externa, superando em $36 \%$ a técnica NSM, para o valor de deslocamento máximo estabelecido por norma (Tabela 5.19).

\begin{tabular}{c|c|c} 
Tabela 5.19 - Deslocamento vertical das vigas comparadas \\
\hline Trabalho & Viga & $\begin{array}{c}\text { Força para } \\
\boldsymbol{\delta}=\mathbf{1 2 , 8 m m}(\mathbf{k N})\end{array}$ \\
\hline \multirow{4}{*}{ Atual } & VB2 & 76,50 \\
\cline { 2 - 3 } & VC1 & 88,50 \\
\cline { 2 - 3 } & VC2 & 84,77 \\
\cline { 2 - 3 } & VD1 & 78,00 \\
\cline { 2 - 3 } & VD2 & 78,00 \\
\hline \multirow{4}{*}{$\begin{array}{c}\text { Ferrari } \\
(2007)\end{array}$} & V1C & 110,00 \\
\cline { 2 - 3 } & V2C & 120,00 \\
\hline
\end{tabular}

Equivalente a viga VB2, foi a V1C de Ferrari (2007), reforçada com três camadas de manta sem inserção do compósito cimentício. Nesse caso, o aumento de carga entre as técnicas foi menos pronunciado. A carga atingida pela viga VB2 foi 50\% superior à viga de referência, enquanto a V1C proporcionou $69 \%$ de aumento. Mesmo aqui, sem o compósito 
cimentício, a técnica com manta apresentou-se mais rígida que a técnica proposta, com aproximadamente $44 \%$ de aumento de carga para o deslocamento estabelecido por norma.

Ao mesmo tempo em que as variações de carga e rigidez, em geral, foram elevadas, deve-se considerar a diferença na quantidade de reforço imposta às vigas. Sabendo-se que as vigas possuem as mesmas armaduras e praticamente a mesma resistência do concreto, a diferença concentra-se no reforço utilizado. A Tabela 5.20 apresenta valores para essa comparação:

Tabela 5.20 - Quantidade de reforço existente nos dois trabalhos

\begin{tabular}{c|c|c|c}
\hline Trabalho & Quantidade & $\begin{array}{c}\text { Resistência à } \\
\text { tração (MPa) }\end{array}$ & $\begin{array}{c}\text { Resistência } \\
\text { total à tração } \\
\text { (MPa) }\end{array}$ \\
\hline Atual & 2 Laminados & 1363 & 2726 \\
\hline $\begin{array}{c}\text { Ferrari } \\
(2007)\end{array}$ & 3 Mantas & 3169 & 9507 \\
\hline
\end{tabular}

Essa comparação, embora ilustrativa, permite uma visualização da diferença de reforço imposto à viga. Ao se utilizar camadas de manta, o aproveitamento do reforço não é total, diminuindo conforme se aumenta a quantidade de camadas. Por isso não se pode dizer que toda essa resistência é efetiva. Porém, através da deformação, observa-se o aproveitamento do reforço, já que ambas as configurações de PRFC (manta e laminado) respeitam a lei de Hooke até o rompimento (Tabela 5.21).

Tabela 5.21 - Deformação no reforço

\begin{tabular}{c|c|c|c}
\hline Trabalho & Viga & $\begin{array}{c}\text { Deformação máxima } \\
\text { do reforço (\%) }\end{array}$ & $\begin{array}{c}\text { Deformação no } \\
\text { reforço(\%) }\end{array}$ \\
\hline \multirow{4}{*}{ Atual } & VB2 & & 9,38 \\
\cline { 2 - 2 } & VC1 & & 9,46 \\
\cline { 2 - 2 } & VC2 & \multirow{2}{*}{10,9} & 9,58 \\
\cline { 2 - 2 } & VD1 & & 8,33 \\
\cline { 2 - 2 } & VD2 & & 8,02 \\
& & & \\
& & & \\
\hline
\end{tabular}




\begin{tabular}{l|c|c|c}
\hline \multirow{2}{*}{$\begin{array}{c}\text { Ferrari } \\
(2007)\end{array}$} & V1C & \multirow{2}{*}{13,1} & 4,00 \\
\cline { 2 - 2 } & V2C & & 5,70 \\
\hline
\end{tabular}

Nesse quesito, a técnica NSM apresentou-se muito mais econômica que a colagem externa de manta, com $88 \%$ de aproveitamento do reforço contra $43 \%$, ocorrendo nas vigas com compósito cimentício inserido em toda a extensão. Multiplicando a resistência total à tração pelo aproveitamento do reforço de cada técnica, verifica-se que a manta tem quase o dobro de capacidade de carga que o laminado. Logo, as diferenças mudam de proporção, levando a uma equivalência entre os resultados obtidos.

Sendo assim, num caso real, se a necessidade de incremento de carga girar em torno de $100 \%$, a técnica NSM apresenta-se como a mais econômica. Porém, se a necessidade de aumento de carga for maior, recomenda-se a técnica de reforço externo com manta. Mesmo com menor aproveitamento do material, a técnica de aderência externa permite o uso de camadas, já a técnica NSM, esbarra na limitação de espaço físico para inserção dos laminados. Lembrando, do Capítulo 2, que alguns autores estudam a área de influência das barras de aço e dos laminados para que não haja destacamento do cobrimento do concreto.

O maior problema da aderência externa fica por conta do descolamento prematuro do reforço sem aviso prévio. Nesse sentido, com dupla área de aderência, os laminados proporcionam maior segurança ao reforço.

As cargas de fissuração praticamente não sofreram alteração, acontecendo com $21 \mathrm{kN}$ para a VB2 e $35 \mathrm{kN}$ para a VC1, $25 \mathrm{kN}$ para V1C e $35 \mathrm{kN}$ para a V2C. Esses valores levam a concluir que a quantidade de reforço não adia o surgimento das fissuras ao passo que o compósito cimentício auxilia nesse processo.

No estudo das compatibilizações entre as deformações do aço e do reforço é notada outra diferença entre as técnicas. Enquanto a deformação da manta é ligeiramente maior que a deformação do aço, na técnica NSM ocorre o contrário. Embora haja uma melhor distribuição de tensões ao longo da armadura, a atual técnica não respeita a hipótese de distribuição linear de deformação ao longo da seção transversal da viga.

Em ambas a técnicas, não foi observado deslocamento horizontal, ou se quer, formação de fissuras na junta do concreto da viga com o compósito cimentício. Também não 
se observou na presente técnica, nenhum início de fissuração na região de ancoragem dos laminados.

\subsection{Conclusão}

Observando os resultados das três diferentes propostas de ancoragem do laminado, percebe-se uma significativa melhora nas vigas que tiveram toda a face tracionada reconstituída com o compósito cimentício (grupo C). O início de fissuração foi retardado, houve aumento na capacidade de carga, na rigidez e no aproveitamento dos laminados.

Analisando as forças aplicadas nas vigas, observou-se acréscimo de carga variando entre $39,5 \%$ a 66,6\% em relação às vigas de referência. Os maiores valores foram registrados nas vigas do grupo $\mathrm{C}$, seguidos pelos grupos $\mathrm{B}$ e D. Isso demonstra o efeito positivo proporcionado pela inserção do compósito cimentício distribuído em toda a extensão da viga. Entretanto, observa-se que o compósito apenas nos vãos de cisalhamento, não apresenta a mesma qualidade. No entanto, analisando as cargas máximas atingidas até a interrupção do ensaio, essa sequência se inverte, sendo o grupo D mais resistente que o grupo B.

A deformação no laminado seguiu o mesmo comportamento, com deformação atingindo entre $73 \%$ (VD2) e 87\% (VC2) do valor máximo. Isso se refletiu na rigidez das vigas e na diminuição da fissuração. Para os mesmos valores de carga, o deslocamento vertical das vigas do grupo $\mathrm{C}$ foi sempre inferior aos demais. No caso do deslocamento máximo estabelecido pela ABNT NBR 6118 (2003) para estado limite de serviço, atendendo à limitação visual, a VC1 apresentou-se $30 \%$ mais rígida que a média das vigas de referência. Enquanto isso, as vigas dos grupos B e D tiveram comportamento semelhante e apresentaramse $15 \%$, em média, mais rígidas.

Para as cargas últimas, próximas à interrupção dos ensaios, além do grupo $\mathrm{C}$ apresentar maior valor de carga aplicada, apresentou também o maior deslocamento vertical. Ou seja, o compósito cimentício permitiu que as vigas se deformassem sem destacamento do reforço e com pouca fissuração, comprovando que o objetivo de inserir o compósito cimentício foi atingido, sobretudo na região mais propícia ao surgimento de fissuras. As fibras e microfibras retardaram o surgimento das fissuras pelo aumento da resistência à tração do concreto. 
Entretanto, o uso do compósito apenas nos vãos de cisalhamento não trouxe a resposta esperada, com o desempenho das vigas do grupo D mostrando-se equivalente ao das vigas do grupo B. Logo, pode-se dizer que o compósito cimentício em si, não é o responsável pelo aumento do aproveitamento do reforço. Porém, ele dá subsídios à viga para que haja melhora em seu comportamento perante a solicitação de momentos fletores.

Em comparação com outros trabalhos que utilizaram a técnica NSM e fazendo uso da taxa equivalente de armadura proposta por Fortes (2004), nota-se o aumento da capacidade de carga nas vigas do grupo C. Não houve muita variação na carga de início de fissuração entre os três trabalhos comparados. Porém, nos trabalhos dos outros autores, formaram-se fissuras horizontais próximas às armaduras longitudinais que levaram o reforço à falência. Embora os ensaios do presente trabalho não tenham sido levados à ruptura, não houve sinal de fissuração na região de ancoragem.

Para a viga do grupo $\mathrm{B}$, portanto sem inserção do compósito cimentício, o aproveitamento do laminado foi equivalente ao da viga V1R1 de Fortes (2004), que apresentava taxa equivalente de armadura próxima. A partir da inserção do compósito cimentício, o aproveitamento só aumentou. Esse fato refletiu no aumento de rigidez das vigas. Notou-se a contribuição das fibras e microfibras de aço para aumentar a taxa equivalente de armadura das vigas e torná-las mais rígidas. Ao mesmo tempo, o compósito permitiu que as vigas se deformassem em cargas avançadas, sem destacamento do reforço.

Já na comparação com as vigas reforçadas externamente com manta de PRFC, ensaiadas por Ferrari (2007), elas demonstraram comportamento semelhante em relação à carga máxima e ao início de fissuração. Em ambos os casos, o melhor desempenho foi observado nas vigas com compósito cimentício distribuído em toda face tracionada.

A principal diferença entre as técnicas foi com relação ao aproveitamento do reforço, sendo que a manta apresentou praticamente metade do desempenho do laminado. Isso fez com que as vigas com reforço externo fossem mais dúcteis que as vigas reforçadas com laminado.

Em relação ao dimensionamento das vigas reforçadas (Apêndice B), nota-se que a verificação da seção transversal, considerando simultaneamente a utilização do aço e do laminado, aproxima-se dos resultados obtidos experimentalmente para as vigas dos grupos B e D. De forma mais conservadora, atende aos resultados das vigas do grupo $\mathrm{C}$, nos quais não 
se considerou a resistência à tração do concreto. Portanto, enquanto não há uma norma brasileira específica para tal dimensionamento, esse procedimento apresenta-se coerente.

\subsection{Quesitos práticos}

Pretende-se nessa seção, fazer uma breve descrição das etapas envolvidas na execução do reforço. De uma maneira geral, o procedimento é simples, mas obviamente deve-se considerar as diferenças entre os ambientes e as condições do laboratório e da obra. Sobretudo o posicionamento da viga que, em laboratório, possui total mobilidade para facilitar o trabalho.

A primeira etapa consiste na marcação e apicoamento da região de concreto que deve ser retirada. Esse trabalho, embora dispendioso, é recorrente da construção civil. Por isso, não apresenta transtornos práticos à aplicação do reforço.

Em seguida, vem a etapa de reconstituição da face tracionada da viga. Nesse momento é importante a limpeza da base do concreto que ficou aparente, sem presença de pó e elementos soltos, para possibilitar a união do concreto existente com o compósito cimentício. Essa superfície deve estar na condição saturada/seca.

O compósito cimentício, além de apresentar as resistências desejáveis, deve ter fluidez suficiente para passar pela fôrma conhecida como "cachimbo", ocupar todos os espaços disponíveis, além de garantir a união com o concreto antigo.

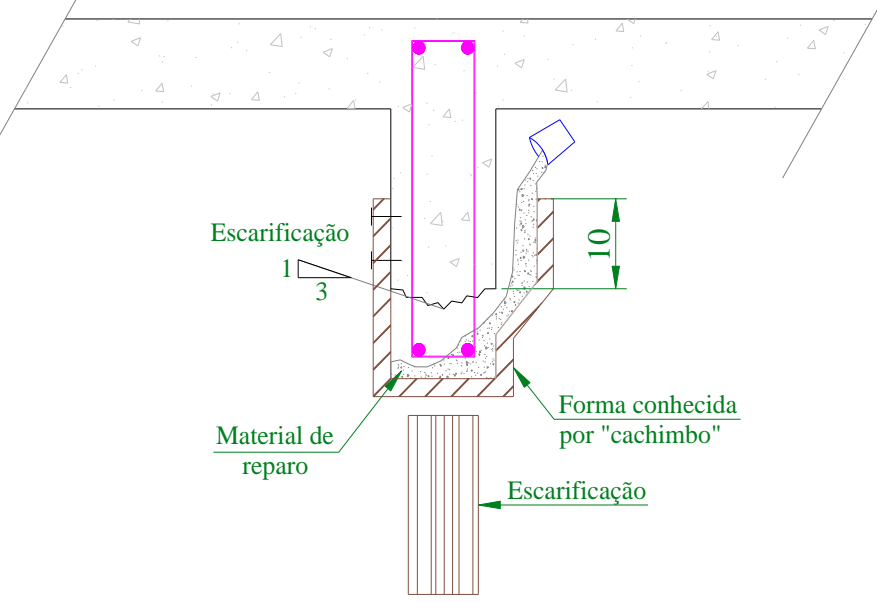

Figura 5.34 - Compósito cimentício sendo incorporado à viga através de "cachimbo" (Adaptado de HELENE, 1992, p.115) 
Após a cura, vem a marcação e a execução do entalhe. Segundo o técnico do laboratório, não há dificuldade em realizar esse procedimento, mesmo com a presença das fibras de aço. O problema ficaria por conta do posicionamento do equipamento acima da cabeça expelindo água.

Com os entalhes secos e limpos, é o momento de aplicar a resina e colar o laminado. Com a resina Sikadur ${ }^{\circledR} 30$, não há problema de excesso de fluidez, apresentando consistência adequada ao tipo de aplicação. Atenção deve ser tomada com a temperatura ambiente, a umidade e a ventilação.

Retirados os excessos, e realizado o acabamento final, deve-se esperar sete dias para secagem da resina e liberação da obra. 

A proposta do presente trabalho foi dar continuidade ao desenvolvimento de uma técnica de reforço à flexão de vigas de concreto armado iniciado por Ferrari (2007), pela qual parte da região tracionada da viga é substituída por um compósito cimentício composto por fibras e microfibras de aço, formando o chamado substrato de transição. O objetivo, além de proporcionar a prévia reparação da viga, é aumentar a eficiência do reforço, que naquele caso foi realizado com manta de polímero reforçado com fibra de carbono (PRFC) colada na face externa. Na pesquisa atual, a novidade foi o emprego da técnica de reforço conhecida como Near Surface Mounted (NSM), pela qual tiras de laminados de PRFC são inseridas no concreto de cobrimento da viga.

Os resultados demonstraram que o objetivo proposto foi cumprido. A reconstituição de toda face tracionada da viga proporcionou aumento da capacidade de carga, diminuição da fissuração, aumento de rigidez e melhor aproveitamento das tiras de laminado. O compósito permitiu também, que em cargas avançadas, as vigas se deformassem sem destacamento do reforço.

$\mathrm{Na}$ prática, tal comportamento é de extrema importância. O rompimento frágil do reforço pode causar problemas graves à estrutura existente, ao passo que o aparecimento de flecha perceptível pode alertar o proprietário ou o profissional contratado para algum problema que esteja ocorrendo com o elemento estrutural.

Essa propriedade não foi encontrada em outros trabalhos, nos quais, em estágios mais avançados de carregamento, observou-se a formação de fissuras horizontais que acarretaram o desprendimento dos laminados.

Sendo assim, a proposta do uso do compósito cimentício distribuído em toda a face tracionada da viga é uma boa alternativa para complementar a técnica NSM. Embora pareça ser um trabalho dispendioso, em muitos casos a recuperação do concreto é imprescindível para poder receber o reforço. Nessa situação, a única alteração pode ser o custo do concreto, facilmente recompensado pelos benefícios proporcionados.

Não se pode esquecer a importância da confirmação da qualidade dos materiais utilizados, que muitas vezes não correspondem às especificações do fabricante. A pesquisa 
das marcas com outros profissionais mais experientes também é fundamental, uma vez que as características variam muito de um fornecedor para outro e nem sempre proporcionam o resultado esperado.

Por fim, a inspeção do reforço de maneira regular é algo de suma importância. Como o próprio nome diz, trata-se uma estrutura que passou por uma intervenção para se adequar às novas necessidades. No caso de uma falha, a estrutura voltará a ter sua capacidade de carga reduzida, podendo ocorrer o colapso estrutural.

\subsection{Sugestões para trabalhos futuros}

Como sugestão para trabalhos futuros, propõe-se:

- o estudo mais aprimorado do comprimento de ancoragem das tiras de laminado, buscando maior economia do sistema;

- o desenvolvimento da modelagem computacional das vigas em comparação aos resultados experimentais obtidos;

- o estudo da influência da taxa de armadura convencional da viga em relação ao rendimento do reforço;

- o estudo da interferência de campos de tensões provocada pela proximidade dos laminados no concreto de cobrimento, o que pode propiciar o desprendimento do reforço;

- estudo dinâmico do reforço segundo a técnica NSM. 
AÏTICIN, P. C. (2000). Concreto de alto desempenho. São Paulo: Pini. Cap. 5, p. 104-105.

ALMEIDA FILHO, F. M. (2006). Contribuição ao estudo da aderência entre barras de aço e concretos auto-adensáveis. 310f. Tese (Doutorado) - Escola de Engenharia de São Carlos, Universidade de São Paulo, São Carlos, 2006.

AMERICAN CONCRETE INSTITUTE (1987). ACI Committee 226: Silica Fume in Concrete. Farmington Hills.

AMERICAN CONCRETE INSTITUTE (1989). ACI Committee 544.2R: Measurement of Properties of Fiber Reinforced Concrete. Farmington Hills.

AMERICAN CONCRETE INSTITUTE (2003). ACI Committee 440.1R: Guide for the Design and Construction of Structural Concrete Reinforced with FRP Bars. Farmington Hills.

AMERICAN SOCIETY FOR TESTING AND MATERIALS (2008). ASTM D 3039/D 3039M: Standard test method for tensile properties of polymer matrix composite materials. West Conshohocken, PA.

ANDRADE, J. J. O. (2006). Vida Útil das Estruturas de Concreto. Concreto: Ensino, Pesquisa e Realizações, São Paulo, v. 2, p. 949-950.

ASSOCIAÇÃO BRASILEIRA DE NORMAS TÉCNICAS (1994). ABNT NBR 5739: Concreto - Ensaios de compressão de corpos-de-prova cilíndricos. Rio de Janeiro. 
ASSOCIAÇÃO BRASILEIRA DE NORMAS TÉCNICAS (1994). ABNT NBR 7222: Argamassa e concreto - Determinação da resistência à tração por compressão diametral de corpos-de-prova cilíndricos. Rio de Janeiro.

ASSOCIAÇÃO BRASILEIRA DE NORMAS TÉCNICAS (1997). ABNT NBR 13956: Sílica ativa para uso em cimento Portland, concreto, argamassa e pasta de cimento Portland Especificação. Rio de Janeiro.

ASSOCIAÇÃO BRASILEIRA DE NORMAS TÉCNICAS (1997). ABNT NBR 13957: Sílica ativa para uso em cimento Portland, concreto, argamassa e pasta de cimento Portland Métodos de ensaio. Rio de Janeiro.

ASSOCIAÇÃO BRASILEIRA DE NORMAS TÉCNICAS (1999). ABNT NBR 5674: Manutenção de edificações - Procedimento. Rio de Janeiro.

ASSOCIAÇÃO BRASILEIRA DE NORMAS TÉCNICAS (2003). ABNT NBR 6118: Projeto de estruturas de concreto - Procedimento. Rio de Janeiro.

ASSOCIAÇÃO BRASILEIRA DE NORMAS TÉCNICAS (2003). ABNT NBR 8522: Concreto - Determinação do módulo estático de elasticidade à compressão. Rio de Janeiro.

ASSOCIAÇÃO BRASILEIRA DE NORMAS TÉCNICAS (2007). ABNT NBR 15530: Fibras de aço para concreto - Especificação. Rio de Janeiro.

BARBOSA, M. P.; HAMOUINE, A.; LORRAIN, M. (1997). Aderência aço-concreto: comportamento da ligação aço-concreto de elevado desempenho. XXVIII Jornadas SulAmericanas de Engenharia Estrutural, São Carlos, v.5, n.28, p. 1841-1850, setembro, 1997. 
BARROS, J. (2003). Comportamento à flexão de betão reforçado com fibras de aço: caracterização experimental e conceitos para uso em projecto. Portugal: DEC-UM. Relatório Técnico.

BARROS, J.; ANTUNES, A. (2004). Reforço de pavimentos de edifícios industriais com laminados de fibras de carbono. In: ENCONTRO NACIONAL BETÃO ESTRUTURAL, 2004, Porto. Anais... Porto: FEUP. p. 767-774

BARROS, J. A. O. et al. (2003). Investigação no âmbito da utilização de materiais compósitos no reforço de estruturas de betão. Simpósio EPUSP sobre Estruturas de Concreto, v. 5, p. $1-18$.

BARROS, J. A. O; CRUZ, J. S. (2001). Fracture energy of steel fiber-reinforced concrete. Journal of Mechanics of Composite Materials and Structures, v.8 (1), p. 29-45.

BARROS, J. A. O.; FORTES, A. S. (2005). Flexural strengthening of concrete beam with CFRP laminates bonded into slits. Cement \& Concrete Composites, v. 27, n.4, p. 471-480, abril.

BARROS, J. A. O.; SENA-CRUZ, J. M.; DIAS, S.; FERREIRA, D.; FORTES, A. (2004). Near surface mounted CFRP-based technique for the strengthening of concrete structures. In: JORNADA TÉCNICA EN HONOR A RAVINDRA GETTU. Anais... Barcelona: Universitat Politècnica de Catalunya.

BEBER, A. J.; CAMPOS FILHO, A.; CAMPAGNOLO, J. L. (2000). Reforço de estruturas e concreto armado com tecidos pré-impregnados de fibras de carbono. Revista Téchne, São Paulo, n.45, p. 52-55, mar - abr.

BENTUR, A.; MINDESS, S. (1990). Fibre reinforced cementitious composites. New York, Elsevier Applied Science. 
BITTENCOURT, T. N. (1999). Fraturamento do concreto estrutural: aspectos teóricos, computacionais e experimentais, e suas aplicações. 240f. Tese (Concurso de livre docência) - Escola Politécnica, Universidade de São Paulo, São Paulo, 1999.

BLASCHKO, M. (2003). Bond behaviour of CFRP strips glued into slits. In: FRPRCS, 6. Anais...Singapore: World Scientific, p. 205-214.

BONALDO, E.; BARROS, J. A.; LOURENÇO, P. B. (2004). Caracterização do comportamento da ligação entre betões de distinta classe de resistência. In: ENCONTRO NACIONAL BetÃo ESTRUTURAL. Anais... Porto: CEC - EST - Comunicações a Conferências Nacionais. p. 1-8

BONALDO, E.; BARROS, J. A. O.; LOURENÇO, P. B. (2005). Concrete slabs strips reinforced with epoxy-bonded carbon laminates into slits. In INTERNATIONAL CONFERENCE ON CONSTRUCTION MATERIALS, 3., 2005, Vancouver, Canada. Anais... 1 CD-ROM.

BONALDO, E.; BARROS, J. A. O.; LOURENÇO, P. B. (2006). Sistema híbrido em materiais compósitos para reforço de lajes de betão armado. In: JORNADAS PORTUGUESAS DE ENGENHARIA DE ESTRUTURAS, 4., 2006, Lisboa. Anais... 1 CDROM.

BONALDO, E.; BARROS, J. A.; LOURENÇO, P. B. (2007). Influence of the spacing between NSM-CFRP laminates on the flexural strengthening efficacy of RC slabs. In: INTERNATIONAL SYMPOSIUM ON FIBER REINFORCED POLYMER REINFORCEMENT FOR CONCRETE STRUCTURES, 8. Anais... Patras: University Patras. p. 1-11

BONALDO, E.; CASTRO-GOMES, J. P.; BARROS, J. A. O.; LOURENÇO, P. B. (2005). SEM analysis of bond epoxy based layer between hardened concrete and SFRC repairing. In: EUROSEMINAR ON MICROSCOPY APPLIED TO BUILDING MATERIALS, 10., 2005, Scotland, UK. Anais... 1 CD-ROM. 
CALDAS, A; FIGUEIREDO, A. D.; BITTENCOURT, T. N. (2003). Propriedades de concreto reforçados com fibras de aço (CRFA): comparação entre métodos de medida. Simpósio EPUSP sobre Estruturas de Concreto, São Paulo, v. 5, p. 1-11

CASTRO, E. K. (2005). Reforço em vigas "T" de concreto armado com vários tipos de compósitos em entalhes no cobrimento de concreto (CEC). 431f. Tese (Doutorado) Faculdade de Tecnologia, Universidade de Brasília, Brasília, 2005.

CONCRETO COM FIBRAS DE AÇO (2000). São Paulo: Editora Universidade de São Paulo, 2000. ISSN 0103-9830.

CRUZ, J. S.; BARROS, J. A. O. (2003). Modelação da ligação de laminados de CFRP inseridos no betão de recobrimento. In: CONGRESSO DE MECÂNICA APLICADA E COMPUTACIONAL, 7., 2003, Évora. Anais... Évora: University of Évora. p. 587-596

CRUZ, J. S.; BARROS, J. A. O.; GETTU, R. (2004). Comportamento da ligação de laminados de CFRP inseridos no betão sob acções cíclicas. In: CONGRESSO DE SISMOLOGIA E ENGENHARIA SÍSMICA, 6., 2004, Guimarães. Anais... Guimarães: Universidade do Minho, p. 591-600

DE LORENZIS, L.; LUNDGREN, K.; RIZZO A. (2004). Anchorage length of near-surface mounted fiber-reinforced polymer bars for concrete strengthening - experimental investigation and numerical modeling. ACI Structures Journal, v.101, n.2, p.269-278, março-abril.

DE LORENZIS, L.; NANNI, A. (2002). Bond between near-surface mounted FRP rods and concrete in structural strengthening. ACI Structures Journal, v. 99, n.2, p. 123-133, marçoabril.

DE LORENZIS, L.; RIZZO A.; LA TEGOLA, A. (2002). A modified pull-out test for Bond of near-surface mounted FRP rods in concrete. Composites Part B: Engineering, v. 33, n.8, p.589-603, dezembro. 
DE LORENZIS, L.; TENG, J. G. (2007). Near-surface mounted FRP reinforcement: An emerging technique for strengthening structures. Composites Part B: Engineering, v. 38, n.2, p.119-143, março.

DIAS, S.; BARROS, J. (2004). Avaliação da eficácia de distintas técnicas de reforço ao corte de vigas de betão armado com CFRP. Encontro Nacional Betão Estrutural. Porto: FEUP.

EL HACHA, R.; RIZKALLA, S. (2004). Near-surface-mounted fiber-reinforced polymer reinforcements for flexural strengthening of concrete structures. ACI Structures Journal, v.101, n.5, p.717-726, setembro-outubro.

FERRARI, V. J. (2007). Reforço à flexão de vigas de concreto armado com manta de polímero reforçado com fibras de carbono (PRFC) aderido a substrato de transição constituído por compósito cimentício de alto desempenho. 328f. Tese (Doutorado) Escola de Engenharia de São Carlos, Universidade de São Paulo, São Carlos, 2007.

FERREIRA, L. E. T. (2002). Sobre a resistência ao fraturamento do concreto e do concreto reforçado com fibras de aço. 327f. uTese (Doutorado) - Escola Politécnica de São Paulo, Universidade de São Paulo, São Paulo, 2002.

FIGUEIREDO, A. D. (2000). Concreto com fibras de aço. ISSN 0103-9830, BT/PCC/260, 2000.

FIGUEIREDO, A. D. (2005). Concreto com fibras. IBRACON. Concreto: ensino, pesquisa e realizações. São Paulo: Instituto Brasileiro do Concreto. Cap. 39, p. 1195-1225.

FONSECA, T. C. C. S. (2007). Reforço e incremento da rigidez à flexão de ligações vigapilar de estruturas de concreto pré-moldado com polímero reforçado com fibra de carbono (PRFC). 203f. Dissertação (Mestrado) - Escola de Engenharia de São Carlos, Universidade de São Paulo, São Carlos, 2007. 
FORTES, A. S. (2004). Estruturas de concreto submetidas à flexão reforçadas com laminados de CFRP colados em entalhes. 230f. Tese (Doutorado) - Universidade Federal de Santa Catarina, Florianópolis, 2004.

GIONGO, J. S. (2008). Concreto armado: dimensionamento considerando o estado limite último de elementos estruturais lineares submetidos à ação de momento fletor. SET 409 Estruturas de Concreto I. São Carlos, abril, 2008.

GRIGOLI, A. S.; HELENE, P. R. L. (2001). Comportamento das Adições Minerais Inertes em Poros e Zona de Transição em Concretos. In: CONGRESSO BRASILEIRO DE CIMENTO, 43., 2001, Foz do Iguaçu. Anais... São Paulo: Instituto Brasileiro do Concreto. p. 11.

HASSAN, T.; RIZKALLA, S. (2002). Bond mechanisms of near surface mounted FRP bars and strips for flexural strengthening of concrete structures. In: INTERNATIONAL CONFERENCE ON STRUCTURAL HEALTH MONITORING OF INNOVATIVE CIVIL ENGINEERING STRUCTURES, 1., 2002, Winnipeg, Canada. Anais... CD-ROM.

HASSAN, T.; RIZKALLA, S. (2003). Investigation of bond in concrete structures strengthened with near surface mounted carbon fiber reinforced polymer strips. Journal of Composites for Construction, v. 7, n.3, p. 248-256, agosto.

HELENE, P. (1949). Manual para reparo, reforço e proteção de estruturas de concreto. 2 ed. São Paulo: Pini, 1992.

HELENE, P. R. L. (1995). Ensaios para controle de adesivos epóxi destinados a estruturas de concreto. Revista A Construção São Paulo. São Paulo: IPT, ed. 3, 8 p.

JUVANDES, L. F. P. (1999). Reforço e reabilitação de estruturas de betão usando materiais compósitos de "CFRP". 396f. Tese (Doutorado) - Faculdade de Engenharia, Universidade do Porto, Porto, 1999. 
KAZEMI, M. T.; FAZILEH, F.; EBRAHIMINEZHAD, M. A. (2007). Cohesive crack model and fracture energy of steel-fiber-reinforced-concrete notched cylindrical specimens. Journal of Materials in Civil Engineering, v.19, n.10, p. 884-890, outubro.

KAZMIERCZAK, C. S. (2005). Proteção Superficial do Concreto. Concreto: Ensino, Pesquisa e Realizações, São Paulo, v. 2, p. 879-900.

KONRAD, R. M. (2003). Os primórdios da resina epóxi. Revista Pisos Industriais. Disponível em: <http://www.pisosindustriais.com.br/materias/noticia.asp?ID=39>. Acesso em: 16 out. 2009.

LEAL, U. (2000). Curativo para concreto. Revista Téchne, São Paulo, n.45, p. 52-55, mar abr.

MACHADO, A. P. (2002). Reforço de Estruturas de Concreto Armado com Fibras de Carbono. São Paulo: Pini. 282 p.

MEHTA, P.K.; MONTEIRO, P.J.M. (1994). Concreto: microestrutura, propriedades e materiais. 1.ed. São Paulo: Instituto Brasileiro do Concreto. Cap. 2, p. 36-40.

MEHTA, P.K.; MONTEIRO, P.J.M. (2008). Concreto: microestrutura, propriedades e materiais. 3.ed. São Paulo: Instituto Brasileiro do Concreto. Cap. 12, p. 517-538.

MEHTA, P.K.; MONTEIRO, P.J.M. (2008). Concreto: microestrutura, propriedades e materiais. 3.ed. São Paulo: Instituto Brasileiro do Concreto. Cap. 13, p. 632-650.

MILLER, K. P (2008). Estudo da fluência em vigas de concreto reforçado com fibras de aço, com aplicação de conceitos da mecânica da fratura. 305f. Dissertação (Mestrado) Escola de Engenharia de São Carlos, Universidade de São Paulo, São Carlos, 2008. 
MINISTÉRIO DA CULTURA. Disponível em:< http://www.cultura.gov.br/site/>. Acesso em: 14 jul. 2009.

MONUMENTA. Disponível em:< http://www.monumenta.gov.br/site/>. Acesso em: 14 jul. 2009.

NAKAMURA, J. (2009). Acidentes anunciados. Revista Téchne, São Paulo, v.152, nov.

OLIVEIRA, L. A. P; RAMOS, M; GOMES, J. P. C. (2005). Dosagem de concreto auto adensável reforçado com fibras de aço. In: Congresso Brasileiro do Concreto, 47., 2005, Olinda. Anais... São Paulo: Instituto Brasileiro do Concreto, p. 568-581.

OLIVEIRA JR., F. S. (2005). Reforço à flexão de vigas "T" de concreto armado com colagem externa e inserção de compósitos com fibra de carbono e barras de aço no concreto de cobrimento. 187f. Dissertação (Mestrado) - Faculdade de Tecnologia, Universidade de Brasília, Brasília, 2005.

PARRETTI, R., NANNI A. (2004), Strengthening of RC members using near surface mounted FRP composites: design overview. Adv Struct Eng 7(6), p.469-483.

PAULON, V. A. (2005). A Microestrutura do Concreto Convencional. Concreto: Ensino, Pesquisa e Realizações, São Paulo, v. 1, p. 583-604.

PAULON, V. A; MONTEIRO, P. J. M (1991). Estudos da microestrutura da zona de transição entre a pasta de cimento e o agregado. São Paulo: Departamento de Engenharia de Construção Civil, Escola Politécnica da USP, 34p. (Boletim Técnico, BT/PCC/43). 
PINTO JR., N. O. (1997). Tenacidade e resistência equivalente à tração na flexão dos concretos reforçados com fibras de aço. In: Jornadas Sul-Americanas de Engenharia Estrutural, 28., 1997, São Carlos. Anais... São Carlos: Departamento de Engenharia de Estruturas/Associação Sulamericana de Engenharia Estrutural, p. 2247-2256.

PROENÇA, S. P. B.; PITUBA, J. J. C. (2000). Características do comportamento mecânico do concreto. Introdução à mecânica do dano e fraturamento. São Carlos, 2000, Capítulo 2.

RILEM TC 162-TDF (2002a): Test and design methods for steel fibre reinforced concrete. Bending test. Materials and Structures/Matériaux et Constructions, v.35, p.579-582, jun.

RILEM TC 162-TDF (2002b): Test and design methods for steel fibre reinforced concrete. Design of steel fibre reinforced concrete using the $\sigma-\mathrm{W}$ method: principles and applications. Materials and Structures/Matériaux et Constructions, v.35, p.262-278, jun.

RILEM TC 162-TDF (2003): Test and design methods for steel fibre reinforced concrete. $\sigma-\varepsilon$ design method. Final Recommendation. Materials and Structures/Matériaux et Constructions, v.36, p.560-567, out.

ROGERTEC $^{\circledR}$. Disponível em: $<$ http://www.rogertec.com.br/Produtos/fitadefibradecarbono.pdf> Acesso em: 12 jun. 2009

ROSSELÓ, C.; ELICES, M. (2004). Fracture of model concrete1. Types of fracture and crack path. Cement and Concrete Research, v.34, n.8, p. 1441-1450, agosto.

SENA-CRUZ, J. M.; BARROS, J. A. O.; AZEVEDO, A. F. M. (2004). Modelação de vigas reforçadas com laminados de CFRP inseridos no betão de recobrimento. In: ENCONTRO NACIONAL BETÃo ESTRUTURAL, 2004, Porto. Anais... Porto: FEUP. p. 727-734 
SHAH, S. P., WEISS, W. J. (1999). Ultra high performance concrete: a look to the future. In: SIMPÓSIO TENDÊNCIA DA ENGENHARIA ESTUTURAL EMPREGANDO CONCRETO DE ALTO DESEMPENHO E CONCRETO REFORÇADO COM FIBRAS, São Paulo. Anais... São Paulo: Escola Politécnica, USP.

SILAEX QUÍMICA LTDA. (2006). Disponível em: 〈http://www.silaex.com.br/epoxi.htm >. Acesso em: 16 out. 2009.

SINAENCO. Disponível em: < http://www.sinaenco.com.br/> Acesso em: 13 out. 2009.

SOARES, C. M.; MARTINS, J. G. (2006). Reforço de estruturas de betão armado com CFR. 1.ed. Porto: Universidade do Porto.

SOUZA, R. A. (2001). Análise de fraturamento em estruturas de concreto utilizando programas de análise estrutural. 265f. Dissertação (Mestrado) - Faculdade de Engenharia Civil, Universidade Estadual de Campinas, Campinas, 2001.

TECNOSIL SÍlICA ATIVA (2008). Sílica Ativa. Disponível em < http://www.tecnosilbr.com.br/silica_ativa.htm\#caracteristicas>. Acesso em: 18 mar. 2008.

UYGUNOGLU, T. (2008). Investigation of microstructure and flexural behavior of steel-fiber reinforced concrete. Materials and Structures, v.41, n.8, p. 1441-1449, abril. 

A dosagem do concreto foi realizada seguindo os procedimentos propostos por Mehta e Monteiro (1994) que se baseiam no relatório do comitê ACI 211. Foi respeitada uma sequiência de nove passos, sendo os seis primeiros iguais para os dois métodos possíveis: peso e volume absoluto. O segundo método é mais preciso e por isso foi escolhido para esse trabalho.

A estimativa foi que o concreto atingisse resistência à compressão de $50 \mathrm{MPa}$ e apresentasse características específicas como trabalhabilidade, resistência à tração considerável e resistência à segregação de agregados e fibras.

A resistência de $50 \mathrm{MPa}$ foi estipulada por ser um valor que permite proporcionar uma considerável resistência à tração, além de comprovadamente, apresentar o comportamento esperado, como ocorreu no trabalho de Ferrari (2007).

Embora o objetivo deste trabalho não fosse produzir um concreto autoadensável, havia a necessidade, devido à forma de aplicação do concreto, de que ele desviasse das armaduras existentes e ocupasse todos os espaços da forma sem uso de vibrador, utilizando apenas o seu peso próprio, sem segregação de nenhum de seus componentes. Por isso, alguns quesitos para produção do concreto autoadensável foram incorporados ao traço proposto. Em paralelo, outros quesitos mereceram atenção especial para permitir que as fibras de aço fossem incorporadas ao concreto sem diminuir a trabalhabilidade.

A seguir são descritos os passos e quesitos utilizados na formulação do traço:

\section{Passo 1: Escolha do abatimento do tronco de cone:}

Para vigas, o valor de abatimento, segundo Mehta e Monteiro (1994), varia de 25 à $100 \mathrm{~mm}$. Adotou-se um valor médio de $60 \mathrm{~mm}$.

\section{Passo 2: Escolha da dimensão máxima característica do agregado graúdo:}

Pelas necessidades de maior fluidez e mobilidade do concreto para desviar das armaduras existentes, foi escolhida a brita 0 , cujo diâmetro varia entre 4,8 $\mathrm{mm}$ e 9,5 mm. 


\section{Passo 3: Estimativa da água e do teor de ar:}

Quando não se têm dados disponíveis ou experiência anteriores com os agregados utilizados na mistura, pode-se estimar os valores através de uma tabela fornecida por Mehta e Monteiro (1994). No caso, foram considerados $208 \mathrm{~kg} / \mathrm{m}^{3}$ de consumo de água e $3 \%$ de ar aprisionado.

\section{Passo 4: Escolha da relação água/cimento:}

O valor desse passo não foi escolhido de acordo com a bibliografia, que apresentava como resistência máxima o valor de $41 \mathrm{MPa}$.

Pesquisando outros trabalhos, Almeida Filho (2006), escreveu sobre concreto autoadensável e colocou limites de 0,25 a 0,40 para valores da relação água/cimento (a/c). Figueiredo (2000), que escreveu sobre concreto reforçado com fibra de aço, sugeriu um valor a/c máximo de 0,55 .

Como o objetivo do concreto desenvolvido não é ser classificado como autoadensável, mas ao mesmo tempo ter propriedades satisfatórias de fluidez, optou-se por utilizar um valor médio entre os limites dos dois autores citados $(0,40$ e 0,55$)$ e adotou-se o valor de 0,48 para a relação a/c.

\section{Passo 5: Estimativa do consumo de cimento:}

O consumo de cimento foi obtido através do quociente entre o consumo de água e o fator $\mathrm{a} / \mathrm{c}$ :

$$
\text { Consumo de cimento }=\frac{\text { Consumo de água }}{\text { fator a } / \mathrm{c}}=\frac{208 \mathrm{~kg} / \mathrm{m}^{3}}{0,48}=433 \mathrm{~kg} / \mathrm{m}^{3}
$$

\section{Passo 6: Estimativa do consumo de agregado graúdo:}

Para brita 0 e areia com módulo de finura igual a 2,40, o consumo de agregado graúdo por $\mathrm{m}^{3}$ de concreto é igual a $0,50 \mathrm{~m}^{3}$, segundo Mehta e Monteiro (1994). Multiplicando esse valor pela massa unitária obteve-se o peso requerido:

$$
\text { Consumo de agregado graúdo }=0,50 \frac{\mathrm{m}^{3}}{\mathrm{~m}^{3}} \cdot 1600 \frac{\mathrm{kg}}{\mathrm{m}^{3}}=800 \mathrm{~kg} / \mathrm{m}^{3}
$$




\section{Passo 7: Estimativa do consumo de agregado miúdo:}

Nessa etapa todos os elementos constituintes do concreto foram definidos com exceção do agregado miúdo. O método do volume absoluto calcula esse consumo através da subtração de $1 \mathrm{~m}^{3}$ de concreto pela soma dos volumes dos outros materiais:

$$
\begin{aligned}
\text { Volume de água } & =208 \mathrm{dm}^{3} \\
\text { Volume de cimento } & =\frac{433 \mathrm{~kg} / \mathrm{m}^{3}}{3,15 \mathrm{~kg} / \mathrm{dm}^{3}}=138 \mathrm{dm}^{3}
\end{aligned}
$$$$
\text { Volume de brita }=\frac{800 \mathrm{~kg} / \mathrm{m}^{3}}{2,87 \mathrm{~kg} / \mathrm{dm}^{3}}=278 \mathrm{dm}^{3}
$$

Volume de ar $=30 \mathrm{dm}^{3}$

$$
\text { TOTAL }=654 \mathrm{dm}^{3}
$$

Ou seja, para completar $1000 \mathrm{dm}^{3}$, faltaram $346 \mathrm{dm}^{3}$, que é o volume de agregado miúdo. Multiplicando esse valor pela massa unitária $\left(2,13 \mathrm{~kg} / \mathrm{m}^{3}\right)$, obteve-se o peso desejado igual a $737 \mathrm{~kg}$.

O traço, em massa, encontrado foi o seguinte:

$$
1: 1,70: 1,85: 0,48
$$

\section{Passo 8: Ajustes devidos à umidade dos agregados:}

Considerando que os agregados estão saturados com a superfície seca, não houve correção à umidade.

\section{Passo 9: Ajustes nas misturas experimentais:}

Como foram admitidas várias hipóteses, o traço encontrado, segundo Mehta e Monteiro (1994), deve ser testado em laboratório empregando preferencialmente um volume reduzido de concreto. 
Apêndice A

Mas, antes de testar o traço obtido, foi necessário analisar alguns pontos críticos para que o concreto respondesse satisfatoriamente aos objetivos requeridos.

Um dos objetivos foi a garantia de fluidez do concreto, de maneira que ele conseguisse penetrar entre as armaduras existentes sem deixar vazios. A Figura A.1 mostra como o concreto deve ser incorporado à viga existente:

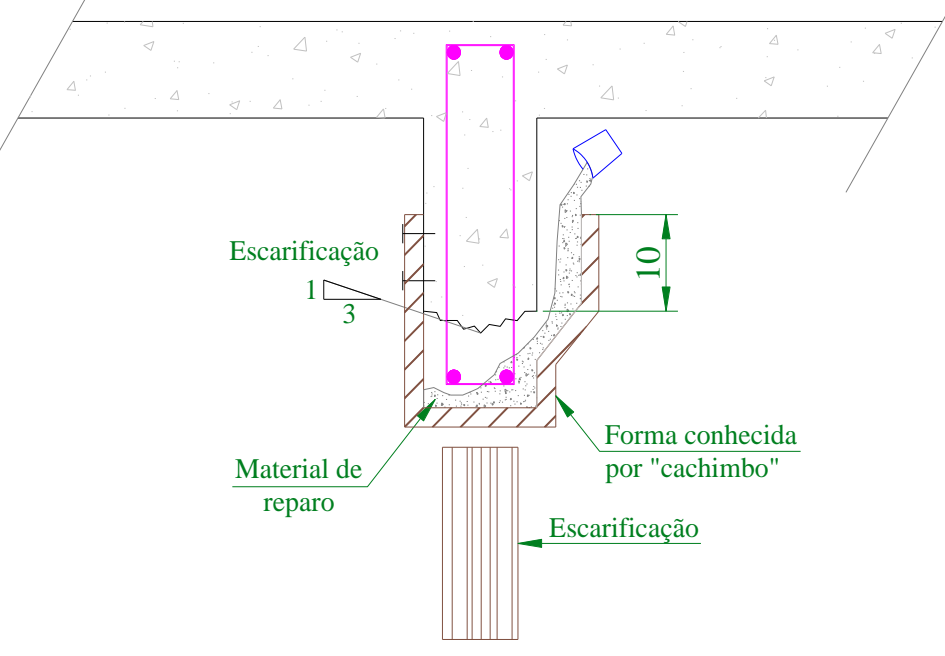

Figura A.1 - Compósito cimentício sendo incorporado à viga através de "cachimbo" (Adaptado de HELENE, 1992, p.115)

Nota-se que durante a moldagem, não é visível a dispersão do concreto, e caso haja formação de vazios, o reforço poderá ficar comprometido.

Pensando nisso, foi proposto o uso do superplastificante Glenium $^{\circledR} 51$, cuja indicação é para produção de concretos de alto desempenho. Segundo sua ficha técnica, o produto reduz a taxa de água em torno de $40 \%$ e apresenta entre $28,5 \%$ e $31,5 \%$ de sólidos. A porcentagem sugerida para o traço em estudo foi baseada no consumo utilizado por Ferrari (2007), que foi de $0,5 \%$ do peso de cimento. Como a dosagem foi muito pequena, não houve necessidade de reparar os consumos de água e areia.

Ao contrário do que ocorreu com o uso de superplastificante, a inserção de fibras impôs a alteração do traço proposto. Sabendo-se que essa inclusão naturalmente reduz a trabalhabilidade do concreto, alguns artifícios foram utilizados para amenizar o problema.

Para Oliveira, Ramos, e Gomes (2005), a presença de fibras de aço no concreto autoadensável, pode ser pensada como um aumento da fração de agregados graúdos sendo, 
portanto, necessário o aumento da fração fina. Por isso, os autores propuseram uma equação que relaciona a argamassa seca com o concreto seco (Equação A.1):

$$
A_{s}(\%)=\frac{1+f+a}{1+f+m} \cdot 100
$$

onde:

1 = proporção unitária, em massa, de cimento;

$f$ = proporção em massa de filler ou material fino;

$a=$ proporção em massa de areia;

$m=$ total de agregados (miúdos + graúdos).

Através de análises experimentais, os autores concluíram que o teor de argamassa ótimo varia entre $60 \%$ e $75 \%$, dependendo do volume e do fator de forma das fibras utilizadas.

Em paralelo, foram consideradas também, recomendações de outros autores. Almeida Filho (2006) diz que a razão ideal entre agregados finos e agregados totais para concreto de alto desempenho, deve ser de 47,5\%. Figueiredo (2000) sugere que para um teor de argamassa mínimo de 50\%, deve haver no máximo $11,5 \%$ da relação água/materiais secos.

Uma maneira de respeitar todas as exigências foi diminuir o consumo de agregado graúdo, ao passo em que se aumentava o consumo de agregado miúdo. Voltando aos "Passos 6 e 7":

\section{Passo 6: Estimativa do consumo de agregado graúdo:}

Considerando $0,46 \mathrm{~m}^{3}$ :

Consumo de agregado graúdo $=0,46 \frac{\mathrm{m}^{3}}{\mathrm{~m}^{3}} \cdot 1600 \frac{\mathrm{kg}}{\mathrm{m}^{3}}=736 \mathrm{~kg} / \mathrm{m}^{3}$ 


\section{Passo 7: Estimativa do consumo de agregado miúdo:}

$$
\begin{aligned}
\text { Volume de água } & =208 \mathrm{dm}^{3} \\
\text { Volume de cimento } & =\frac{433 \mathrm{~kg} / \mathrm{m}^{3}}{3,15 \mathrm{~kg} / \mathrm{dm}^{3}}=138 \mathrm{dm}^{3} \\
\text { Volume de brita } & =\frac{736 \mathrm{~kg} / \mathrm{m}^{3}}{2,87 \mathrm{~kg} / \mathrm{dm}^{3}}=256 \mathrm{dm}^{3} \\
\text { Volume de ar } & =30 \mathrm{dm}^{3} \\
\text { TOTAL } & =632 \mathrm{dm}^{3}
\end{aligned}
$$

Ou seja, o volume de agregado miúdo foi de $368 \mathrm{dm}^{3}$. Multiplicando esse valor pela massa unitária $\left(2,13 \mathrm{~kg} / \mathrm{m}^{3}\right)$, obteve-se o peso desejado igual a $784 \mathrm{~kg}$.

O traço modificado, em massa, foi:

$$
1: 1,81: 1,70: 0,48
$$

Em seguida, realizaram-se algumas iterações, aumentando o consumo de areia para que os quesitos, dos diferentes autores, fossem respeitados.

Ao final, optou-se pelo seguinte traço:

$$
1: 2,30: 1,70: 0,48
$$

O consumo de material por $\mathrm{m}^{3}$ do traço proposto de concreto pode ser visto na Tabela A.1: 
Apêndice A

Tabela A.1 - Consumo por $\mathrm{m}^{3}$ do traço de concreto proposto

\begin{tabular}{cc}
\hline Material & Consumo $\left(\mathbf{k g} / \mathbf{m}^{\mathbf{3}}\right)$ \\
\hline Cimento CPV ARI & 443,0 \\
Areia & 1018,9 \\
Brita 0 & 753,1 \\
Água & 212,6 \\
Superplastificante $_{\text {Glenium }}{ }^{51}$ & 2,22 \\
\hline
\end{tabular}


Como explicado no Capítulo 2, o dimensionamento do reforço deve ser realizado fazendo uso de adaptações de normas vigentes, como por exemplo, a ABNT NBR 6118 (2003) e o ACI 440.1R-03. A proposta aqui é utilizar as resistências dos materiais, obtidas em ensaios de caracterização, para verificar a capacidade de carga da viga com dois laminados inseridos no concreto de cobrimento.

\section{Capacidade de carga da viga antes do reforco (ABNT NBR 6118:2003):}

Como a viga é proveniente do trabalho de Ferrari (2007), apenas foi realizada uma verificação de sua capacidade de carga. Para isso, foi utilizado o equilíbrio de forças internas, de acordo com a Figura B.1:

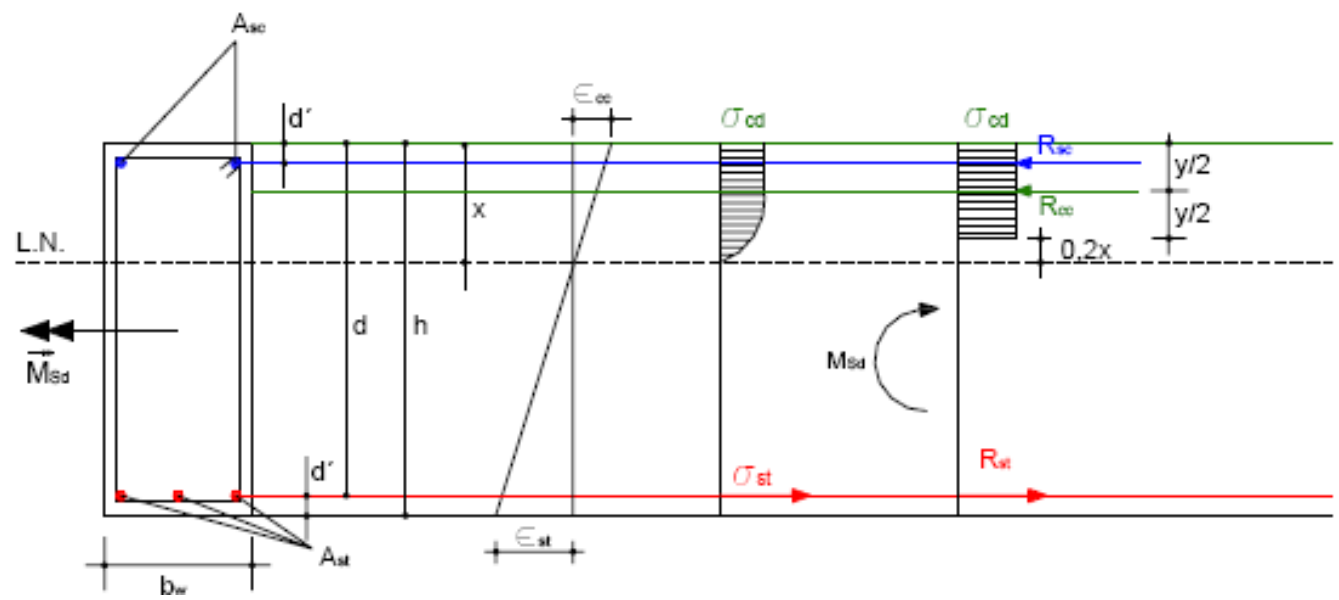

Figura B.1 - Seção transversal retangular (GIONGO, 2008, p.5)

O momento fletor no ponto de aplicação da resistência do concreto à compressão $\left(R_{C C}\right)$, denominado ponto $A$, é (Equação B.1):

$$
\Sigma M_{A}=0 \rightarrow M_{A}=R_{s t}(d-0,4 . x)+R_{s c}\left(d^{\prime}-0,4 . x\right)
$$


onde:

$M_{A}=$ momento resistente da seção no ponto $A ;$

$R_{s t}=$ resistência do aço à tração;

$R_{s c}=$ resistência do concreto à compressão;

$d=$ distância do centro de gravidade da barra de aço tracionada à fibra mais comprimida do concreto;

$x$ = distância da fibra de concreto mais comprimida à linha neutra na condição de tensão equilibrada;

$d^{\prime}=$ distância do centro de gravidade da barra de aço comprimida à fibra mais comprimida do concreto.

Sem apresentar armadura de compressão, a equação B.1 desenvolvida, apresentou-se da seguinte maneira (Equação B.2):

$$
M_{A}=A_{s t} \cdot \varepsilon_{s t} \cdot E_{s t} \cdot(d-0,4 . x)
$$

onde:

$M_{A}=$ momento resistente da seção no ponto $A$;

$A_{s t}=$ área da armadura longitudinal tracionada;

$\varepsilon_{s t}=$ deformação na armadura longitudinal tracionada;

$E_{s t}=$ módulo de elasticidade do aço;

$d=$ distância do centro de gravidade da barra de aço tracionada à fibra mais comprimida do concreto;

$x=$ distância da fibra de concreto mais comprimida à linha neutra na condição de tensão equilibrada; 
Os dados disponíveis foram:

Tabela B.1 - Dados disponíveis para cálculo do momento resistente da seção

\begin{tabular}{c}
\hline$A_{s t}=1,23 \mathrm{~cm}^{2}$ \\
\hline$\varepsilon_{s t}=2,07 \% 0$ \\
\hline$E_{s t}=210 \mathrm{GPa}$ \\
\hline$d=31,745 \mathrm{~cm}$ \\
$x=8,22 \mathrm{~cm}$
\end{tabular}

O que resultou num momento resistente igual a $\mathbf{M}=\mathbf{3 0 , 5 6} \mathbf{~ k N . m . ~}$

Para proporcionar esse momento, de acordo com a situação esquemática do ensaio, deve ser aplicada uma força total de $64 \mathrm{kN}$.

\section{Capacidade de carga da viga se existissem apenas os laminados (ACI 440.1R-03):}

Caso houvessem apenas dois laminados, sem existência das barras de aço, o momento resistente seria obtido através das formulações propostas pelo ACI 440.1R (2003). Assim, considerando o colapso da viga através da ruptura do laminado (Equações B.2 e B.3):

$$
\begin{gathered}
M_{n}=0,8 \cdot A_{f} \cdot f_{f u} \cdot\left(d-\frac{\beta_{1} c_{b}}{2}\right) \\
c_{b}=\left(\frac{\varepsilon_{c u}}{\varepsilon_{c u}+\varepsilon_{f u}}\right) \cdot d
\end{gathered}
$$

onde:

$M_{n}=$ momento resistente;

$A_{f}=$ área de reforço de PRF;

$f_{f u}=$ resistência à tração de cálculo de uma barra de PRF;

$d$ = distância do centro de gravidade de PRF à fibra mais comprimida do concreto; 
$c_{b}=$ distância da fibra de concreto mais comprimida à linha neutra na condição de tensão equilibrada;

$\varepsilon_{c u}=$ deformação última do concreto;

$\varepsilon_{f u}=$ deformação de cálculo do PRF.

com:

Tabela B.2 - Dados disponíveis para cálculo do momento resistente do reforço

\begin{tabular}{c}
\hline$A_{f}=33,73 \mathrm{~mm}^{2}$ \\
\hline$f_{f u}=52,67 \mathrm{kN}$ \\
\hline$d=31,745 \mathrm{~cm}$ \\
\hline$\beta_{1}=0,8$ \\
\hline$c_{b}=6,14 \mathrm{~cm}$ \\
\hline$\varepsilon_{c u}=3 \% 0$ \\
\hline$\varepsilon_{f u}=12,5 \% 0$
\end{tabular}

resultaria num momento resistente igual a $\mathbf{M}=\mathbf{3 0 , 8 6} \mathbf{~ k N . m . ~}$

Para proporcionar esse momento, de acordo com a situação esquemática do ensaio, deve ser aplicada uma força total de $65 \mathrm{kN}$.

Porém, não se pode somar os dois momentos resistentes e esquecer a resistência à compressão do concreto. Isso poderia causar o esmagamento da região comprimida da viga. Por isso, mais uma fez foi realizada a verificação da seção através do equilíbrio das forças internas, considerando as barras de aço e também os laminados:

$$
\Sigma M_{A}=0 \rightarrow M=R_{s t}(d-0,4 . x)+R_{l t}(d+e-0,4 . x)+R_{s c}\left(d^{\prime}-0,4 . x\right)
$$


Nesse caso, o momento resistente é igual a $\mathbf{5 6 , 8 6} \mathbf{~ k N . m}$, sendo necessária uma carga aplicada de $120 \mathrm{kN}$.

Com esses valores, é possível verificar, após o ensaio final, se a adaptação no dimensionamento é coerente com os valores obtidos experimentalmente. 